\title{
Expanded Kekulenes
}

Wei Fan, ${ }^{\dagger}$ Yi Han,$^{\dagger}$ Xuhui Wang, ${ }^{\dagger}$ Xudong Hou,,$^{\dagger}$ Jishan Wu ${ }^{*+,+\dagger}$

†Department of Chemistry, National University of Singapore, 3 Science Drive 3, 117543, Singapore

$\ddagger$ Joint School of National University of Singapore and Tianjin University, International

Campus of Tianjin University, Bin-hai New City, Fuzhou 350207, China.

\section{Table of contents}

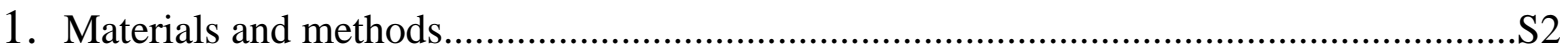

2. Synthetic procedures and characterization data.................................................S2

3. Additional spectra.................................................................

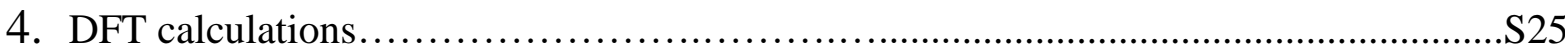

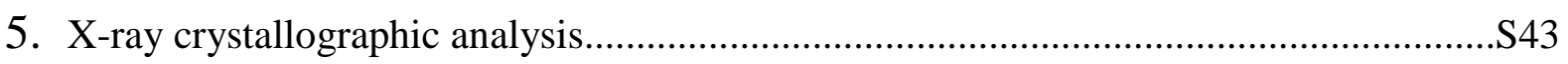

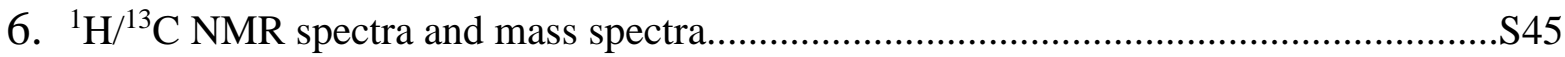

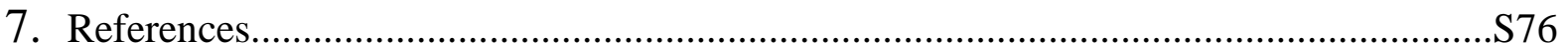




\section{Materials and methods}

The starting material 1,3,5-tribromobenzene, 2, 3, 4, 6 and 7 were obtained from commercial suppliers and directly used without further purification unless otherwise noted. Compound $\mathbf{1}$ was synthesized according to the previous literature. ${ }^{1}{ }^{1} \mathrm{H}$ NMR and ${ }^{13} \mathrm{C}$ NMR spectra were recorded in the deuterated solvents on a Bruker AVANCE 400 NMR Spectrometer and a Bruker AVIII 500WB NMR Spectrometer. ${ }^{1} \mathrm{H}$ NMR chemical shifts were reported in ppm using the residual protonated solvent as an internal standard and tetramethylsilane (TMS) as reference. High resolution mass spectroscopic measurements were performed on Agilent UPLC-QtoF 6540 by electrospray ionization (ESI) or on Agilent 5975C DIP/MS mass spectrometer by electron ionization (EI) or on IonSpec 4.7 Tesla Fourier Transform Mass Spectrometer (MALDI-TOF). UV-vis-NIR absorption spectra were recorded on a Shimadzu UV-3600 spectrophotometer. The absolute quantum yields were recorded on a JASCO model FP-6600 spectrofluorometer, equipped with integrating sphere. Time-resolved fluorescence spectroscopic measurements were conducted on a Hamamatsu model compact fluorescence lifetime spectrometer C11367 (Quantaurus-Tau). Cyclic voltammetry (CV) and differential pulse voltammetry (DPV) were performed with a Zahner IM6e electrochemical workstation using glassy carbon disc as the working electrode, $\mathrm{Pt}$ wire as the counter electrode, $\mathrm{Ag} / \mathrm{AgCl}$ electrode as the reference electrode. The solution of $0.1 \mathrm{M}$ tetrabutylammonium hexafluorophosphate $\left(\mathrm{TBAPF}_{6}\right)$ dissolved in chlorobenzene was employed as the supporting electrolyte. Ferrocene was used as an internal reference.

\section{Synthetic procedures and characterization data}<smiles>CCOc1cc2cc(Br)c(Br)cc2cc1Br</smiles>

1

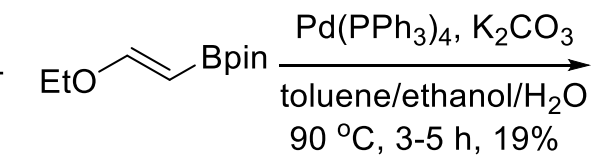

2

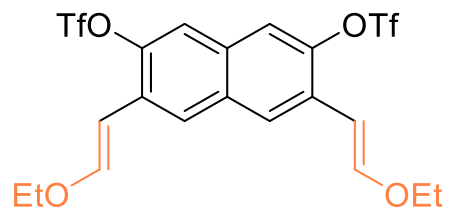

B

\section{Compound B:}

Compound 1 (300 mg, $0.515 \mathrm{mmol})$, compound 2 (0.4 mL, $1.89 \mathrm{mmol}), \mathrm{Pd}\left(\mathrm{PPh}_{3}\right)_{4}(12 \mathrm{mg}$, $0.10 \mathrm{mmol})$ and $\mathrm{K}_{2} \mathrm{CO}_{3}(142 \mathrm{mg}, 1.03 \mathrm{mmol})$ were dissolved in toluene/ethanol/ $\mathrm{H}_{2} \mathrm{O}(15 / 3 / 3$ $\mathrm{mL}$ ) in a sealed tube with a stirrer bar under $\mathrm{N}_{2}$ atmosphere. The reaction mixture was heated for $3-5 \mathrm{~h}$ at $90{ }^{\circ} \mathrm{C}$. After cooling to the room temperature, the reaction mixture was extracted with dichloromethane (DCM). The organic layer was separated and dried over anhydrous sodium sulfate. The solvent was removed under vacuum and the residue was purified by silica gel column chromatography (Hexane:DCM $=5: 1$ ). The crude product was further recrystallized from methanol and DCM at low temperatures $\left(-20^{\circ} \mathrm{C}\right)$ to give $\mathbf{B}$ as a white solid (55 mg, 19\%). This procedure was repeated several times to accumulate enough compounds. ${ }^{1} \mathrm{H}$ NMR $\left(400 \mathrm{MHz}, 298 \mathrm{~K}, \mathrm{CDCl}_{3}\right): \delta$ ppm $7.88(\mathrm{~s}, 2 \mathrm{H}), 7.65$ (s, 2H), $6.98(\mathrm{~d}, J$ $=12.7 \mathrm{~Hz}, 2 \mathrm{H}), 6.18(\mathrm{~d}, J=12.7 \mathrm{~Hz}, 2 \mathrm{H}), 3.99(\mathrm{q}, J=7.0 \mathrm{~Hz}, 4 \mathrm{H}), 1.39$ (t, $J=7.0 \mathrm{~Hz}, 6 \mathrm{H})$. ${ }^{13} \mathrm{C}$ NMR $\left(100 \mathrm{MHz}, \mathrm{CDCl}_{3}\right): \delta$ ppm 149.7, 134.9, 132.1, 131.9, 129.8, 123.0, 122.1, 105.2, 65.7, 14.7, 1.0. ${ }^{19} \mathrm{~F}$ NMR (377 MHz, $\left.\mathrm{CDCl}_{3}\right): \delta \mathrm{ppm}-73.59$. 


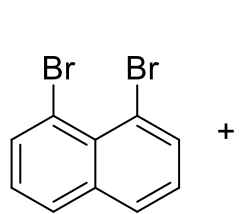

3<smiles>CC(C)(C)c1ccc(B(O)O)cc1</smiles>

4
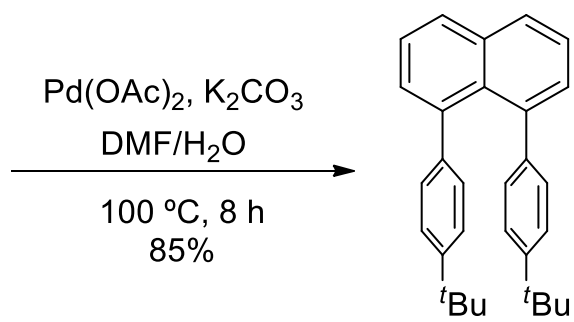

5

\section{Compound 5:}

Compound 3 (1.0 g, $3.50 \mathrm{mmol})$, compound 4 (2.49 g, $13.99 \mathrm{mmol}), \mathrm{Pd}(\mathrm{OAc})_{2}(15.7 \mathrm{mg}$, $0.07 \mathrm{mmol})$ and $\mathrm{K}_{2} \mathrm{CO}_{3}(2.9 \mathrm{~g}, 20.98 \mathrm{mmol})$ were dissolved in DMF $(50 \mathrm{~mL})$ and $\mathrm{H}_{2} \mathrm{O}$ $(50 \mathrm{~mL})$. The reaction mixture was heated for $8 \mathrm{~h}$ at $100{ }^{\circ} \mathrm{C}$ under $\mathrm{N}_{2}$ atmosphere. After cooling to the room temperature, the reaction mixture was extracted with DCM. The combined organic layers were washed with water and dried over $\mathrm{MgSO}_{4}$. After removal of the solvent under vacuum, the residue was purified by silica gel chromatography (Hexane:DCM = 3:1) to afford compound 5 (1.17 g, 85\%) as white solid. ${ }^{1} \mathrm{H}$ NMR (400 MHz, $\left.298 \mathrm{~K}, \mathrm{CDCl}_{3}\right): \delta \mathrm{ppm} 7.91\left(\mathrm{dd},{ }^{3} J=8.2 \mathrm{~Hz},{ }^{4} J=1.0 \mathrm{~Hz}, 2 \mathrm{H}\right), 7.55-7.52(\mathrm{~m}, 2 \mathrm{H}), 7.39\left(\mathrm{dd},{ }^{3} J\right.$ $\left.=7.0 \mathrm{~Hz},{ }^{4} \mathrm{~J}=1.2 \mathrm{~Hz}, 2 \mathrm{H}\right), 6.99-6.95(\mathrm{~m}, 8 \mathrm{H}), 1.22(\mathrm{~s}, 18 \mathrm{H}) .{ }^{13} \mathrm{C} \mathrm{NMR}\left(100 \mathrm{MHz}, \mathrm{CDCl}_{3}\right): \delta$ ppm 148.2, 140.7, 140.4, 135.6, 131.1, 129.5, 129.4, 128.1, 125.1, 123.9, 34.2, 31.4. HRMS analysis $\left(\mathrm{EI}^{+}, \mathrm{m} / z\right)$ calcd for $\mathrm{C}_{30} \mathrm{H}_{32}: 392.2499$, found 392.2501 (error: $0.5 \mathrm{ppm}$ ).

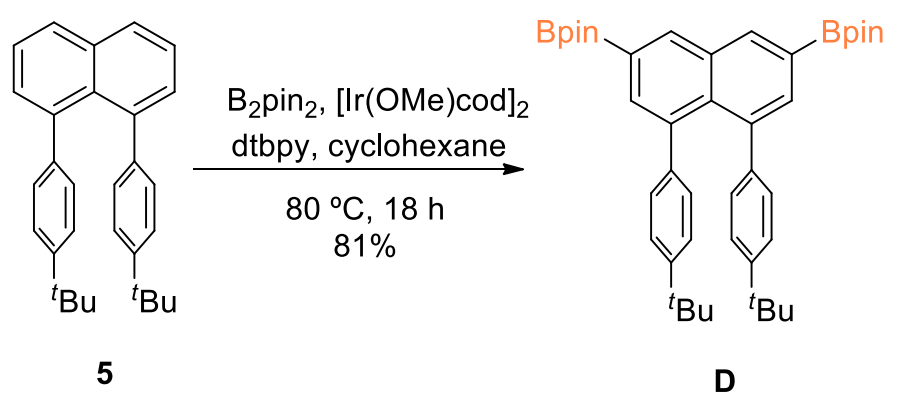

\section{Compound D:}

Compound 5 (1.0 g, $2.55 \mathrm{mmol})$, bis(pinacolato)diboron $(1.42 \mathrm{~g}, 5.60 \mathrm{mmol})$, (1,5-cyclooctadiene)(methoxy)iridium(I) dimer $\quad(84 \quad \mathrm{mg}, \quad 0.13 \quad \mathrm{mmol})$ and 4,4'-di-tert-butyl-2,2'-bipyridine (dtbpy) (93 $\mathrm{mg}, 0.255 \mathrm{mmol}$ ) were dissolved in dry cyclohexane $(40 \mathrm{~mL})$ in a sealed tube with a stirrer bar. The reaction mixture was heated for $18 \mathrm{~h}$ at $80{ }^{\circ} \mathrm{C}$ under $\mathrm{N}_{2}$ atmosphere. After cooling to the room temperature, solvent was removed under the reduced pressure and the residue was quickly purified by silica gel column chromatography (DCM). The crude product was recrystallized from methanol and DCM at low temperatures $\left(-20{ }^{\circ} \mathrm{C}\right)$ to afford compound $\mathbf{D}(1.33 \mathrm{~g}, 81 \%)$ as white solid. ${ }^{1} \mathrm{H}$ NMR (400 $\mathrm{MHz}, 298 \mathrm{~K}, \mathrm{CDCl}_{3}$ ): $\delta$ ppm 8.47 (s, 2H), 7.77 (s, 2H), 6.95 (br, 8H), 1.37 (s, 24H), 1.19 (s, $18 \mathrm{H}) .{ }^{13} \mathrm{C} \mathrm{NMR}\left(100 \mathrm{MHz}, \mathrm{CDCl}_{3}\right): \delta \mathrm{ppm} 148.1,140.4,139.6,137.2,136.7,134.3,132.6$, $129.5,123.8,83.9,34.2,31.4,24.9$. HRMS analysis $\left(\mathrm{ESI}^{+}, \mathrm{m} / z\right)$ calcd for $\mathrm{C}_{42} \mathrm{H}_{54}[11 \mathrm{~B}]_{2} \mathrm{O}_{4}$ : 644.4203, found 644.4208 (error: $0.8 \mathrm{ppm}$ ). 
<smiles>Cc1cc(C)c(Br)c(C)c1</smiles>

6<smiles>Brc1cc(Br)cc(Br)c1</smiles>
$\underset{\text { toluene/ethanol/ } / \mathrm{H}_{2} \mathrm{O}}{\mathrm{Pd}\left(\mathrm{PPh}_{3}\right)_{4}, \mathrm{~K}_{2} \mathrm{CO}_{3}}$ $90^{\circ} \mathrm{C}, 12 \mathrm{~h}, 47 \%$<smiles>Cc1cc(C)c(-c2cc(Br)cc(Br)c2)c(C)c1</smiles>

9

\section{Compound 9:}

Compound 6 (1.0 g, $6.10 \mathrm{mmol})$, 1,3,5-tribromobenzene (3.84 g, $12.20 \mathrm{mmol})$, $\mathrm{Pd}\left(\mathrm{PPh}_{3}\right)_{4}$ $(140.9 \mathrm{mg}, \quad 0.122 \mathrm{mmol})$ and $\mathrm{K}_{2} \mathrm{CO}_{3}(1.68 \mathrm{~g}, 12.2 \mathrm{mmol})$ were dissolved in toluene/ethanol/ $\mathrm{H}_{2} \mathrm{O}(20 / 5 / 5 \mathrm{~mL})$ in a sealed tube with a stirrer bar under $\mathrm{N}_{2}$ atmosphere. The reaction mixture was heated for $12 \mathrm{~h}$ at $90{ }^{\circ} \mathrm{C}$. After cooling to the room temperature, the reaction was extracted with DCM. The organic layer was separated and dried over anhydrous sodium sulfate. The solvent was removed under vacuum, and the residue was purified by silica gel column chromatography (Hexane:DCM $=4: 1$ ) to give compound 9 as white solid $(1.01 \mathrm{~g}, 47 \%) .{ }^{1} \mathrm{H}$ NMR $\left(400 \mathrm{MHz}, 298 \mathrm{~K}, \mathrm{CDCl}_{3}\right): \delta \mathrm{ppm} 7.65(\mathrm{t}, J=1.8 \mathrm{~Hz}, 1 \mathrm{H}), 7.24(\mathrm{~d}, J$ $=1.8 \mathrm{~Hz}, 2 \mathrm{H}), 6.92(\mathrm{~s}, 2 \mathrm{H}), 2.32(\mathrm{~s}, 3 \mathrm{H}), 2.00(\mathrm{~s}, 6 \mathrm{H}) .{ }^{13} \mathrm{C} \mathrm{NMR}\left(100 \mathrm{MHz}, \mathrm{CDCl}_{3}\right): \delta \mathrm{ppm}$ $144.9,137.5,136.1,135.6,132.3,131.2,128.3,122.9,21.0,20.7$. HRMS analysis $\left(\mathrm{EI}^{+}, \mathrm{m} / \mathrm{z}\right)$ calcd for $\mathrm{C}_{15} \mathrm{H}_{14}[79 \mathrm{Br}]_{2}: 351.9457$, found 351.9458 (error: $0.3 \mathrm{ppm}$ ).
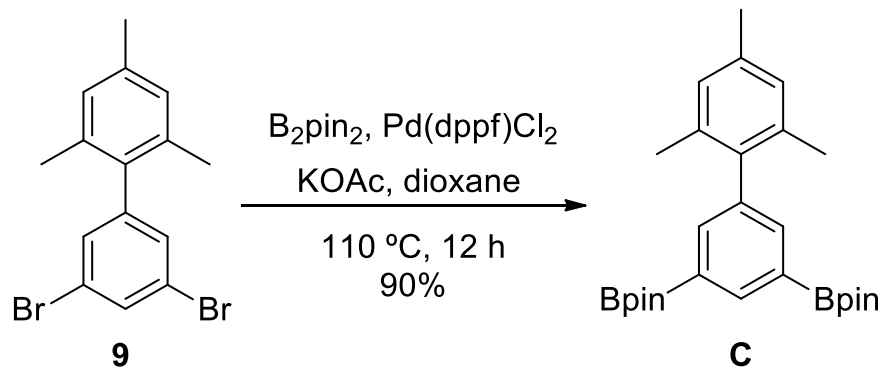

Compound $\mathbf{C}$ :

Compound 9 (1.0 g, $2.82 \mathrm{mmol})$, bis(pinacolato)diboron (2.87 g, $11.30 \mathrm{mmol}), \mathrm{Pd}(\mathrm{dppf}) \mathrm{Cl}_{2}$ $(83 \mathrm{mg}, 0.113 \mathrm{mmol})$ and KOAc $(574 \mathrm{mg}, 5.65 \mathrm{mmol})$ were dissolved in dry dioxane $(20 \mathrm{~mL})$ in a sealed tube with a stirrer bar. The reaction mixture was heated for $12 \mathrm{~h}$ at $110^{\circ} \mathrm{C}$ under $\mathrm{N}_{2}$ atmosphere. After cooling to the room temperature, solvent was removed under the reduced pressure and the residue was quickly purified by silica gel column chromatography (DCM). The crude product was recrystallized from methanol and DCM at low temperatures $\left(-20{ }^{\circ} \mathrm{C}\right)$ to afford compound $\mathbf{C}(1.14 \mathrm{~g}, 90 \%)$ as white solid. ${ }^{1} \mathrm{H}$ NMR $(400 \mathrm{MHz}, 298 \mathrm{~K}$, $\left.\mathrm{CDCl}_{3}\right): \delta \mathrm{ppm} 8.23(\mathrm{~s}, 1 \mathrm{H}), 7.68(\mathrm{~d}, J=1.1 \mathrm{~Hz}, 2 \mathrm{H}), 6.88(\mathrm{~s}, 2 \mathrm{H}), 2.30(\mathrm{~s}, 3 \mathrm{H}), 1.96(\mathrm{~s}, 6 \mathrm{H})$, $1.33(\mathrm{~s}, 24 \mathrm{H}) .{ }^{13} \mathrm{C} \mathrm{NMR}\left(100 \mathrm{MHz}, \mathrm{CDCl}_{3}\right): \delta \mathrm{ppm} 139.9,139.3,138.5,136.2,135.8,127.8$, 83.7, 24.9, 21.0, 20.9. HRMS analysis $\left(\mathrm{EI}^{+}, \mathrm{m} / \mathrm{z}\right)$ calcd for $\mathrm{C}_{27} \mathrm{H}_{38}[11 \mathrm{~B}]_{2} \mathrm{O}_{4}$ : 448.2951, found 448.2963 (error: 2.7 ppm). 
<smiles>Brc1c2ccccc2cc2ccccc12</smiles>

6<smiles>Cc1cc(C)c(B(O)O)c(C)c1</smiles>

7

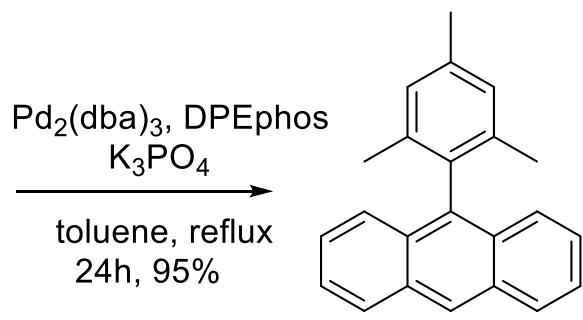

8

Compound 8:

Compound 6 (1 g, $3.89 \mathrm{mmol})$, compound 7 (1.91 g, $11.67 \mathrm{mmol}), \mathrm{Pd}_{2}(\mathrm{dba})_{3}(143 \mathrm{mg}, 0.156$ mmol) and $\mathrm{K}_{3} \mathrm{PO}_{4}(1.65 \mathrm{~g}, 7.78 \mathrm{mmol})$ were dissolved in dry toluene $(100 \mathrm{~mL})$ under $\mathrm{N}_{2}$ atmosphere. The reaction mixture was heated to reflux for $24 \mathrm{~h}$. After cooling to the room temperature, the reaction mixture was added $\mathrm{H}_{2} \mathrm{O}$ and extracted with DCM. The organic layer was separated and dried over anhydrous sodium sulfate. The solvent was removed under vacuum and the residue was purified by silica gel column chromatography (Hexane) to give compound 8 as white solid $(1.1 \mathrm{~g}, 95 \%) .{ }^{1} \mathrm{H}$ NMR $\left(400 \mathrm{MHz}, 298 \mathrm{~K}, \mathrm{CDCl}_{3}\right)$ : $\delta$ ppm 8.49 (s, $1 \mathrm{H}), 8.07(\mathrm{~d}, J=8.4 \mathrm{~Hz}, 2 \mathrm{H}), 7.50-7.45(\mathrm{~m}, 4 \mathrm{H}), 7.36-7.32(\mathrm{~m}, 2 \mathrm{H}), 7.10(\mathrm{~s}, 2 \mathrm{H}), 2.47$ (s, $3 \mathrm{H}), 1.72(\mathrm{~s}, 6 \mathrm{H}) .{ }^{13} \mathrm{C}$ NMR $\left(100 \mathrm{MHz}, \mathrm{CDCl}_{3}\right): \delta \mathrm{ppm} 137.1,135.8,134.5,131.7,129.8$, 128.6, 128.3, 126.1, 126.0, 125.6, 125.2, 21.3, 20.0. HRMS analysis $\left(\mathrm{EI}^{+}, \mathrm{m} / \mathrm{z}\right)$ calcd for $\mathrm{C}_{23} \mathrm{H}_{20}: 296.156$, found 296.1558 (error: $0.7 \mathrm{ppm}$ ).
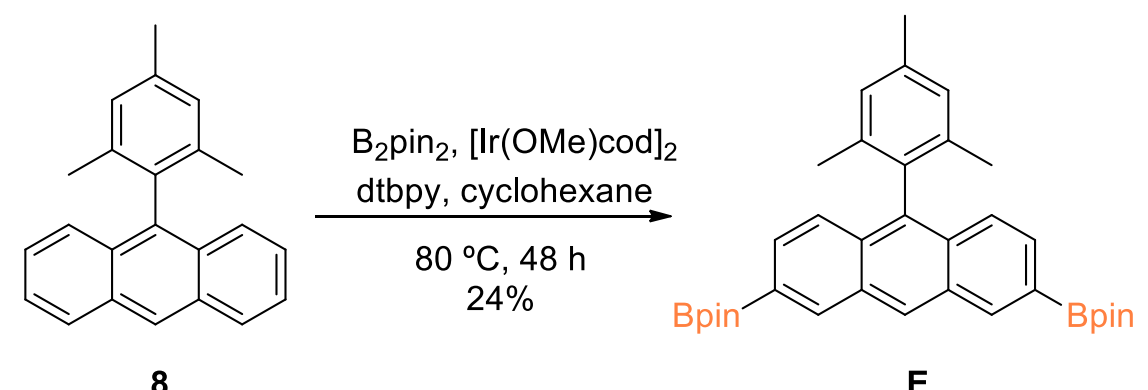

E

Compound $\mathbf{E}$ :

Compound 8 (3.5 g, $11.81 \mathrm{mmol})$, bis(pinacolato)diboron $(6.60 \mathrm{~g}, 25.98 \mathrm{mmol})$, (1,5-cyclooctadiene)(methoxy)iridium(I) dimer $\quad\left(\begin{array}{lllll}392 & \mathrm{mg}, & 0.59 & \mathrm{mmol}\end{array}\right)$ and 4,4'-di-tert-butyl-2,2'-bipyridine $(420 \mathrm{mg}, 1.18 \mathrm{mmol})$ were dissolved in dry cyclohexane $(100 \mathrm{~mL})$ in a sealed tube with stirrer bar. The reaction mixture was heated for $48 \mathrm{~h}$ at $80{ }^{\circ} \mathrm{C}$ under $\mathrm{N}_{2}$ atmosphere. After cooling to room temperature, solvent was removed under the reduced pressure and the residue was quickly purified by silica gel column chromatography (DCM). The crude product was recrystallized from methanol and DCM to afford mixture solid, then the filtrate was collected, dried and recrystallized again from methanol and DCM to afford compound $\mathbf{E}(1.53 \mathrm{~g}, 24 \%)$ as yellow solid. ${ }^{1} \mathrm{H}$ NMR $\left(400 \mathrm{MHz}, 298 \mathrm{~K}, \mathrm{CDCl}_{3}\right)$ : $\delta$ ppm $8.63(\mathrm{~s}, 2 \mathrm{H}), 8.59(\mathrm{~s}, 1 \mathrm{H}), 7.66(\mathrm{~d}, J=8.7 \mathrm{~Hz}, 2 \mathrm{H}), 7.43(\mathrm{~d}, J=8.8 \mathrm{~Hz}, 2 \mathrm{H}), 7.09(\mathrm{~s}, 2 \mathrm{H})$, $2.46(\mathrm{~s}, 3 \mathrm{H}), 1.68(\mathrm{~s}, 6 \mathrm{H}), 1.40(\mathrm{~s}, 24 \mathrm{H}) .{ }^{13} \mathrm{C} \mathrm{NMR}\left(100 \mathrm{MHz}, \mathrm{CDCl}_{3}\right): \delta \mathrm{ppm} 137.6,137.1$, 135.3, 134.3, 131.6, 131.0, 129.9, 128.6, 128.3, 124.9, 84.0, 24.9, 21.3, 19.9. HRMS analysis $\left(\mathrm{ESI}^{+}, m / z\right)$ calcd for $\mathrm{C}_{35} \mathrm{H}_{43}\left[{ }^{11} \mathrm{~B}_{2} \mathrm{O}_{4}: 549.3342\right.$, found 549.3352 (error: $1.8 \mathrm{ppm}$ ). 


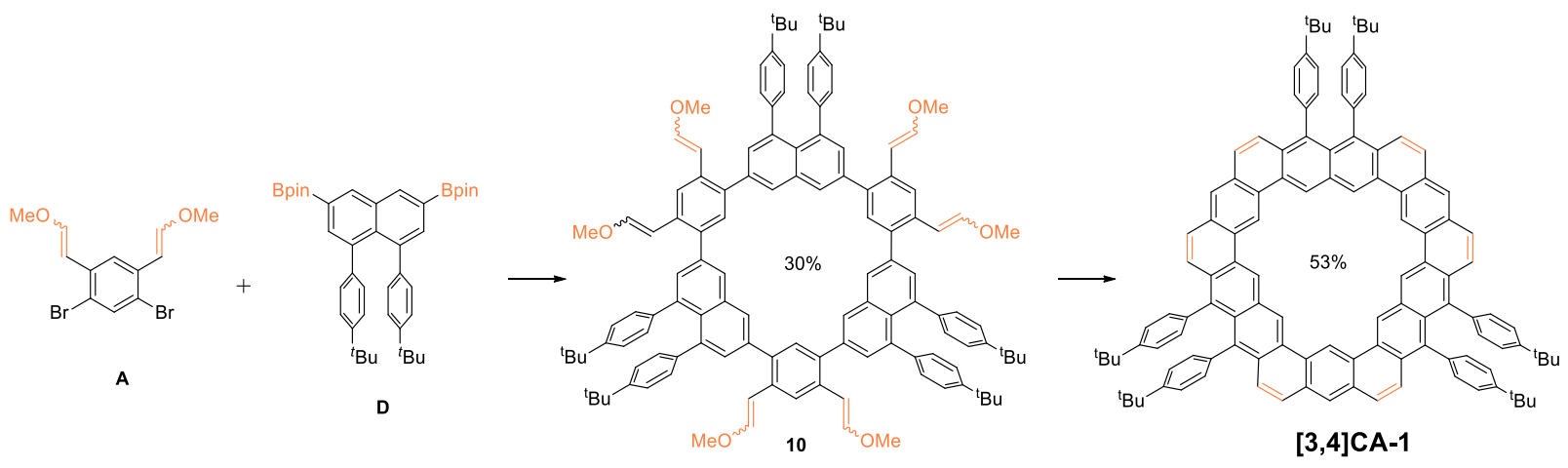

\section{Compounds 10:}

A mixture of $\mathbf{A}(216 \mathrm{mg}, 0.62 \mathrm{mmol}), \mathbf{D}(400 \mathrm{mg}, 0.62 \mathrm{mmol}), \mathrm{NaHCO}_{3}(4.17 \mathrm{~g}, 49.65$ mmol), THF $(400 \mathrm{~mL})$ and $\mathrm{H}_{2} \mathrm{O}(20 \mathrm{~mL})$ was carefully degassed before the addition of $\mathrm{Pd}_{2}(\mathrm{dba})_{3}(56.8 \mathrm{mg}, 0.062 \mathrm{mmol})$ and $\left[(t-\mathrm{Bu})_{3} \mathrm{PH}\right] \mathrm{BF}_{4}(71.9 \mathrm{mg}, 0.248 \mathrm{mmol})$. The mixture was stirred and heated at $80{ }^{\circ} \mathrm{C}$ for 3 days under $\mathrm{N}_{2}$ atmosphere. The organic solvent was removed under the reduced pressure, and then $\mathrm{H}_{2} \mathrm{O}$ and DCM were added. The organic layer was separated and dried over anhydrous sodium sulfate. The solvent was removed under vacuum and the residue was first purified by a short column (silica gel, DCM) to remove the catalysts, and then further purified by preparative $\mathrm{GPC}$ using $\mathrm{CHCl}_{3}$ at a rate of $14 \mathrm{~mL} / \mathrm{min}$ to afford compound $\mathbf{1 0}(54 \mathrm{mg}, 30 \%)$ as white solid. The NMR spectrum of $\mathbf{1 0}$ is complicated due to the existence of multiple cis-/trans- vinyl isomers. Compound 10: HRMS analysis (MALDI, $100 \%, m / z$ ) calcd for $\mathrm{C}_{126} \mathrm{H}_{126} \mathrm{O}_{6}: 1734.9549$, found 1734.9554 (error: $0.3 \mathrm{ppm}$ ).

\section{Compounds [3,4]CA-1:}

A mixture of $10(54 \mathrm{mg}, 0.03 \mathrm{mmol})$ and $\mathrm{Bi}(\mathrm{OTf})_{3}(6.6 \mathrm{mg}, 0.01 \mathrm{mmol})$ in 1,2-dichloroethane (DCE, $40 \mathrm{~mL}$ ) was heated at $90{ }^{\circ} \mathrm{C}$ for 12 hours under $\mathrm{N}_{2}$ atmosphere. The organic solvent was removed under the reduced pressure, and then $\mathrm{H}_{2} \mathrm{O}$ and DCM were added. The organic layer was separated, and dried over anhydrous sodium sulfate. The solvent was removed under vacuum, and the crude product was recrystallized from methanol and THF to afford pure compound [3,4]CA-1 as yellow solid (25 mg, 53\%). ${ }^{1} \mathrm{H}$ NMR $(500 \mathrm{MHz}, 298 \mathrm{~K}$, $\left.\mathrm{CD}_{2} \mathrm{Cl}_{2}\right): \delta \mathrm{ppm} 11.12(\mathrm{~s}, 3 \mathrm{H}), 10.67(\mathrm{~s}, 6 \mathrm{H}), 7.95(\mathrm{~s}, 3 \mathrm{H}), 7.36(\mathrm{~d}, J=9.5 \mathrm{~Hz}, 6 \mathrm{H}), 7.06(\mathrm{~d}, J$ $=8.2 \mathrm{~Hz}, 12 \mathrm{H}), 6.96(\mathrm{~d}, J=9.5 \mathrm{~Hz}, 6 \mathrm{H}), 6.78(\mathrm{~d}, J=8.0 \mathrm{~Hz}, 12 \mathrm{H}), 1.37(\mathrm{~s}, 54 \mathrm{H}) .{ }^{13} \mathrm{C} \mathrm{NMR}$

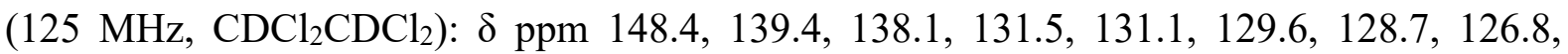
124.0, 34.4, 31.7. HRMS analysis (MALDI, $100 \%, \mathrm{~m} / z$ ) calcd for $\mathrm{C}_{120} \mathrm{H}_{102}: 1542.7976$, found 1542.7973 (error: $0.2 \mathrm{ppm}$ ). 

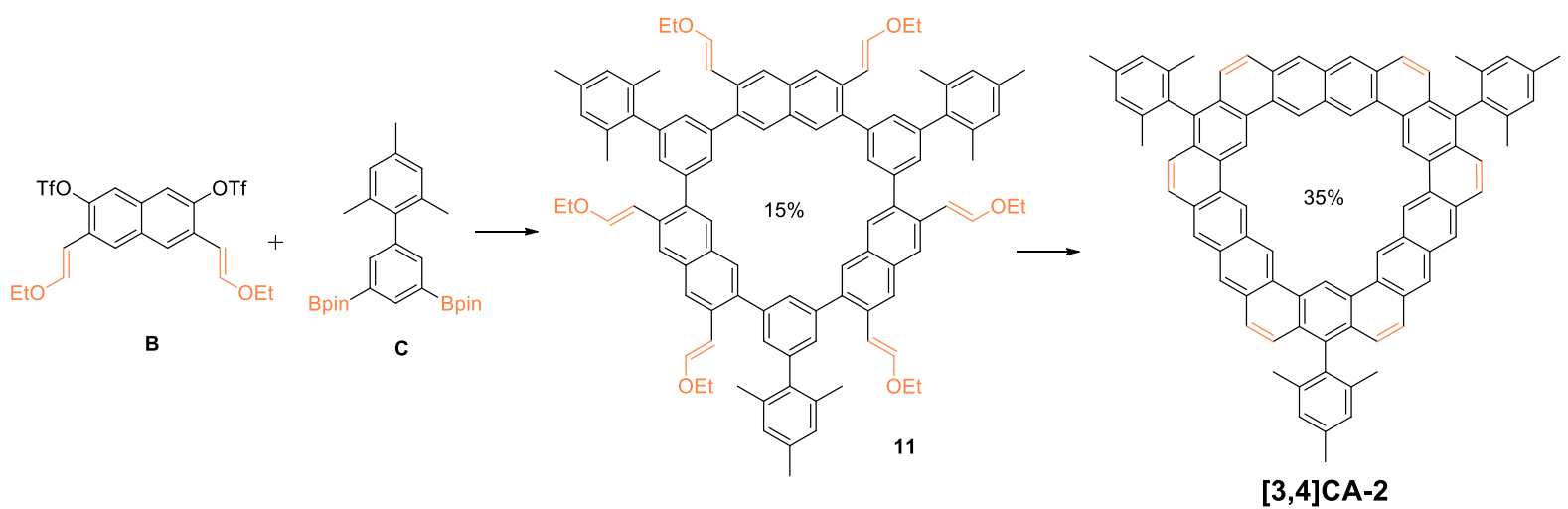

\section{Compounds 11:}

A mixture of $\mathbf{B}(252 \mathrm{mg}, 0.446 \mathrm{mmol}), \mathbf{C}$ (200 mg, $0.446 \mathrm{mmol}), \mathrm{NaHCO}_{3}(3 \mathrm{~g}, 35.7 \mathrm{mmol})$, THF $(300 \mathrm{~mL})$ and $\mathrm{H}_{2} \mathrm{O}(15 \mathrm{~mL})$ was carefully degassed before the addition of $\mathrm{Pd}_{2}(\mathrm{dba})_{3}$ $(40.8 \mathrm{mg}, 0.0446 \mathrm{mmol})$ and $\left[(t-\mathrm{Bu})_{3} \mathrm{PH}_{\mathrm{B}} \mathrm{BF}_{4}(51.9 \mathrm{mg}, 0.178 \mathrm{mmol})\right.$. The mixture was stirred and heated at $80{ }^{\circ} \mathrm{C}$ for 3 days under $\mathrm{N}_{2}$ atmosphere. The organic solvent was removed under the reduced pressure, and then $\mathrm{H}_{2} \mathrm{O}$ and DCM were added. The organic layer was separated, dried over anhydrous sodium sulfate. The solvent was removed under vacuum, and the residue was first purified by a short column (silica gel, DCM) to remove the catalysts, and then further purified by preparative GPC using $\mathrm{CHCl}_{3}$ at a rate of $14 \mathrm{~mL} / \mathrm{min}$ to afford compound 17 (30 mg, 15\%) as white solid. The intermediate 11 was conducted to next step without further purification. ${ }^{1} \mathrm{H}$ NMR $\left(400 \mathrm{MHz}, 298 \mathrm{~K}, \mathrm{CDCl}_{3}\right): \delta \mathrm{ppm} 8.16(\mathrm{~s}, 6 \mathrm{H})$, 7.83-7.82 (m, 3H), $7.80(\mathrm{~s}, 6 \mathrm{H}), 7.40(\mathrm{~s}, 6 \mathrm{H}), 7.04-6.93(\mathrm{~m}, 12 \mathrm{H}), 6.18(\mathrm{~d}, J=12.7 \mathrm{~Hz}, 6 \mathrm{H})$, 3.89-3.84 (m, 12H), $2.35(\mathrm{~s}, 9 \mathrm{H}), 2.32(\mathrm{~s}, 9 \mathrm{H}) 1.95(\mathrm{~s}, 9 \mathrm{H}), 1.32(\mathrm{t}, J=7.0 \mathrm{~Hz}, 18 \mathrm{H}) .{ }^{13} \mathrm{C}$ NMR $\left(100 \mathrm{MHz}, \mathrm{CDCl}_{3}\right): \delta \mathrm{ppm} \mathrm{142.7,} \mathrm{139.0,} \mathrm{138.5,} \mathrm{136.6,} \mathrm{136.3,} \mathrm{135.8,} \mathrm{133.1,} \mathrm{132.6,}$ 131.2, 130.1, 130.1, 129.4, 128.2, 127.9, 122.7, 105.6, 65.3, 29.7, 21.1, 14.8. HRMS analysis (MALDI, $100 \%, m / z$ ) calcd for $\mathrm{C}_{99} \mathrm{H}_{96} \mathrm{O}_{6}: 1380.7201$, found 1380.7210 (error: $-0.6 \mathrm{ppm}$ ).

\section{Compounds $[3,4] \mathrm{CA}-2$ :}

A mixture of $11(30 \mathrm{mg}, 0.0217 \mathrm{mmol})$ and $\mathrm{Bi}(\mathrm{OTf})_{3}(5 \mathrm{mg}, 0.0065 \mathrm{mmol})$ in 1,2-dichloroethane (DCE, $40 \mathrm{~mL}$ ) was heated at $90{ }^{\circ} \mathrm{C}$ for 7 hours under $\mathrm{N}_{2}$ atmosphere. The organic solvent was removed under the reduced pressure, and then $\mathrm{H}_{2} \mathrm{O}$ and DCM were added. The organic layer was separated, and dried over anhydrous sodium sulfate. The solvent was removed under vacuum, and the crude product was recrystallized from methanol and DCM to afford pure compound [3,4]CA-2 as yellow solid (8.5 mg, 35\%). ${ }^{1} \mathrm{H}$ NMR (500 $\left.\mathrm{MHz}, 298 \mathrm{~K}, \mathrm{CDCl}_{2} \mathrm{CDCl}_{2}\right)$ : $\delta \mathrm{ppm} 11.26(\mathrm{~s}, 3 \mathrm{H}), 10.78(\mathrm{~s}, 6 \mathrm{H}), 8.52(\mathrm{~s}, 6 \mathrm{H}), 7.69(\mathrm{~d}, J=9.6$ $\mathrm{Hz}, 6 \mathrm{H}), 7.23(\mathrm{~d}, J=9.4 \mathrm{~Hz}, 6 \mathrm{H}), 7.14(\mathrm{~s}, 6 \mathrm{H}), 2.48(\mathrm{~s}, 9 \mathrm{H}), 1.91(\mathrm{~s}, 18 \mathrm{H}) .{ }^{13} \mathrm{C}$ NMR $(125$ $\mathrm{MHz}, \mathrm{CDCl}_{2} \mathrm{CDCl}_{2}$ ): $\delta$ ppm 137.1, 136.8, 136.7, 133.7, 130.8, 130.7, 130.6, 129.1, 129.0, 128.9, 128.0, 127.6, 125.3, 125.0, 123.3, 116.6, 21.0, 20.1. HRMS analysis (MALDI, 100\%, $\mathrm{m} / z$ ) calcd for $\mathrm{C}_{87} \mathrm{H}_{60}: 1104.4690$, found 1104.4687 (error: $-0.2 \mathrm{ppm}$ ). 


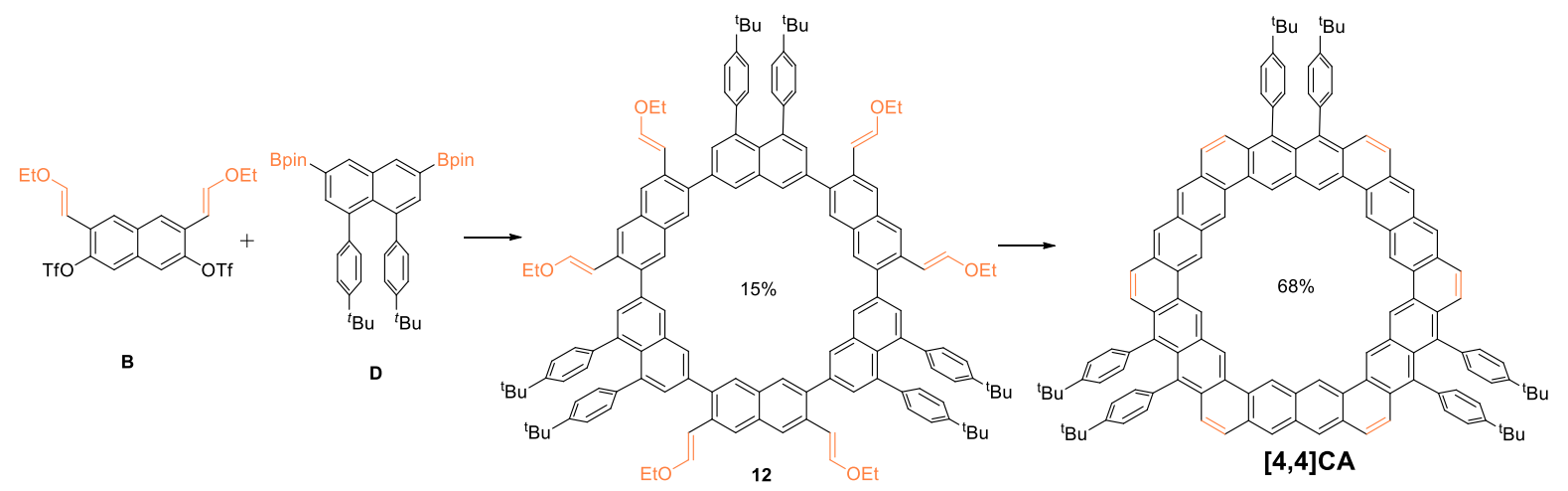

Compounds 12:

A mixture of $\mathbf{B}$ (350 mg, $0.62 \mathrm{mmol}), \mathbf{D}$ (400 mg, $0.62 \mathrm{mmol}), \mathrm{NaHCO}_{3}(4.16 \mathrm{~g}, 49.6 \mathrm{mmol})$, THF $(400 \mathrm{~mL})$ and $\mathrm{H}_{2} \mathrm{O}(20 \mathrm{~mL})$ was carefully degassed before the addition of $\mathrm{Pd}_{2}(\mathrm{dba})_{3}$ $(56.8 \mathrm{mg}, 0.062 \mathrm{mmol})$ and $\left[(t-\mathrm{Bu})_{3} \mathrm{PH}_{\mathrm{BBF}}(72 \mathrm{mg}, 0.248 \mathrm{mmol})\right.$. The mixture was stirred and heated at $80{ }^{\circ} \mathrm{C}$ for 3 days under $\mathrm{N}_{2}$ atmosphere. The organic solvent was removed under the reduced pressure, and then $\mathrm{H}_{2} \mathrm{O}$ and DCM were added. The organic layer was separated, and dried over anhydrous sodium sulfate. The solvent was removed under vacuum and the residue was first purified by a short column (silica gel, DCM) to remove the catalysts, and then further purified by preparative GPC using $\mathrm{CHCl}_{3}$ at a rate of $14 \mathrm{~mL} / \mathrm{min}$ to afford compound 12 (59 mg, 15\%) as white solid. The intermediate 12 was directly used in the next step without further purification. ${ }^{1} \mathrm{H} \mathrm{NMR}\left(400 \mathrm{MHz}, 298 \mathrm{~K}, \mathrm{CDCl}_{3}\right): \delta \mathrm{ppm} 8.21(\mathrm{~d}, J=1.4$ $\mathrm{Hz}, 6 \mathrm{H}), 8.04(\mathrm{~s}, 6 \mathrm{H}), 7.84(\mathrm{~s}, 6 \mathrm{H}), 7.73(\mathrm{~d}, J=1.6 \mathrm{~Hz}, 6 \mathrm{H}), 7.05-6.98(\mathrm{~m}, 30 \mathrm{H}), 6.13(\mathrm{~d}, J=$ $12.7 \mathrm{~Hz}, 6 \mathrm{H}), 3.81-3.70(\mathrm{~m}, 12 \mathrm{H}), 1.22(\mathrm{~s}, 72 \mathrm{H}) .{ }^{13} \mathrm{C} \mathrm{NMR}\left(100 \mathrm{MHz}, \mathrm{CDCl}_{3}\right): \delta \mathrm{ppm} 140.2$, $139.7,138.8,138.1,136.7,133.7,133.4$ 133.0, 129.8, 129.4, 129.1, 128.2, 127.4, 125.3, 123.8, 122.8, 105.5, 65.0, 34.2, 31.4, 14.7. HRMS analysis (MALDI, 100\%, $\mathrm{m} / \mathrm{z}$ ) calcd for $\mathrm{C}_{144} \mathrm{H}_{144} \mathrm{O}_{6}: 1969.0957$, found 1969.0970 (error: $0.6 \mathrm{ppm}$ ).

\section{Compounds $[4,4] \mathrm{CA}$ :}

A mixture of 12 (40 mg, $0.02 \mathrm{mmol})$ and $\mathrm{Bi}(\mathrm{OTf})_{3}(10 \mathrm{mg}, 0.015 \mathrm{mmol})$ in 1,2-dichloroethane (DCE, $40 \mathrm{~mL}$ ) was heated at $90{ }^{\circ} \mathrm{C}$ for 7 hours under $\mathrm{N}_{2}$ atmosphere. After cooling to the room temperature, the reaction was added $\mathrm{H}_{2} \mathrm{O}$ and extracted with DCM. The organic layer was separated, and dried over anhydrous sodium sulfate. The solvent was removed under vacuum and the crude product was recrystallized from methanol and DCM to afford pure compound $[4,4] \mathrm{CA}$ as orange solid $(23 \mathrm{mg}, 68 \%) .{ }^{1} \mathrm{H}$ NMR $(500 \mathrm{MHz}, 373 \mathrm{~K}$, $\mathrm{CDCl}_{2} \mathrm{CDCl}_{2}$ ): $\delta$ ppm $9.55(\mathrm{~s}, 6 \mathrm{H}), 9.54(\mathrm{~s}, 6 \mathrm{H}), 7.98(\mathrm{~s}, 6 \mathrm{H}), 7.19(\mathrm{~d}, J=9.8 \mathrm{~Hz}, 6 \mathrm{H}), 7.08$ $(\mathrm{d}, J=8.2 \mathrm{~Hz}, 12 \mathrm{H}), 6.73(\mathrm{~d}, J=8.0 \mathrm{~Hz}, 12 \mathrm{H}), 6.68(\mathrm{~d}, J=9.5 \mathrm{~Hz}, 6 \mathrm{H}), 1.43(\mathrm{~s}, 54 \mathrm{H}) .{ }^{13} \mathrm{C}$ NMR $\left(125 \mathrm{MHz}, \mathrm{CDCl}_{2} \mathrm{CDCl}_{2}\right.$ ): $\delta$ ppm 147.8, 138.5, 137.8, 131.1, 131.0, 130.8, 130.7, $130.0,129.0,128.5,127.9,126.8,125.9,125.4,123.5,122.8,121.9,34.2,31.5$. HRMS analysis (MALDI, $100 \%, \mathrm{~m} / z$ ) calcd for $\mathrm{C}_{132} \mathrm{H}_{108}$ : 1692.8446 , found 1692.8440 (error: -0.4 ppm). 


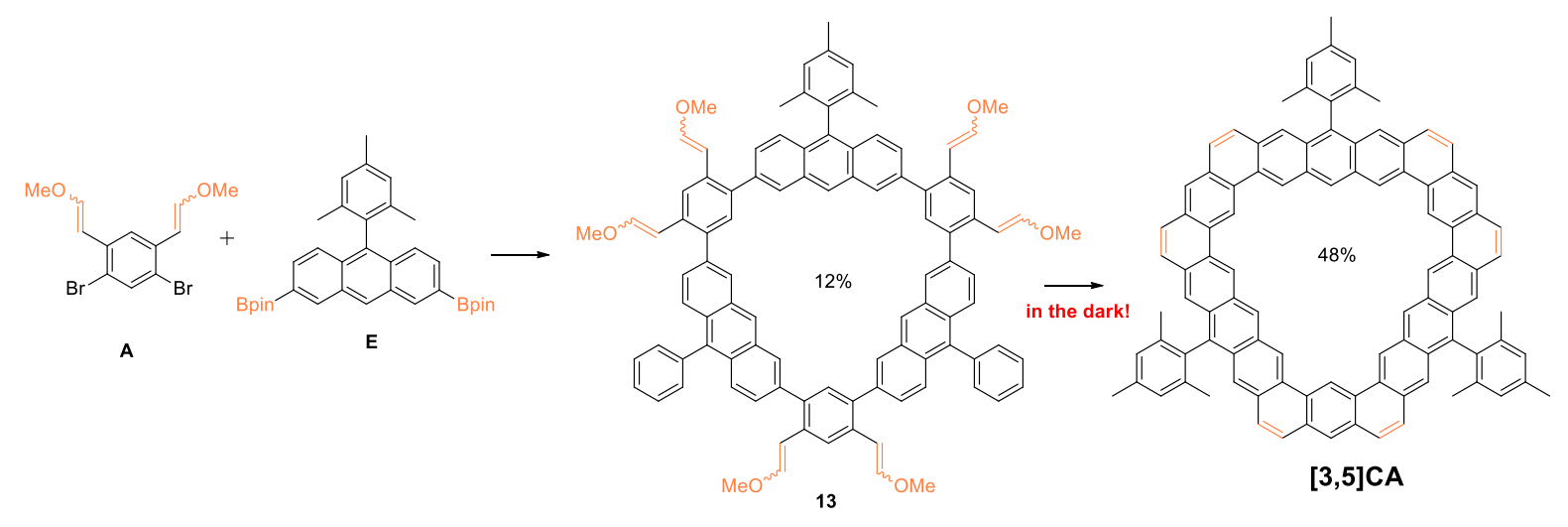

\section{Compounds 13:}

A mixture of A (127 mg, $0.365 \mathrm{mmol}), \mathbf{E}(200 \mathrm{mg}, 0.365 \mathrm{mmol}), \mathrm{NaHCO}_{3}$ (2.25 g, 24.2 mmol), THF $(300 \mathrm{~mL})$ and $\mathrm{H}_{2} \mathrm{O}(15 \mathrm{~mL})$ was carefully degassed before the addition of $\mathrm{Pd}_{2}(\mathrm{dba})_{3}(33.4 \mathrm{mg}, 0.0365 \mathrm{mmol})$ and $\left[(t-\mathrm{Bu})_{3} \mathrm{PH}\right] \mathrm{BF}_{4}(42.4 \mathrm{mg}, 0.146 \mathrm{mmol})$. The mixture was stirred and heated at $80{ }^{\circ} \mathrm{C}$ for 3 days under $\mathrm{N}_{2}$ atmosphere. The organic solvent was removed under the reduced pressure, and then $\mathrm{H}_{2} \mathrm{O}$ and DCM were added. The organic layer was separated, dried over anhydrous sodium sulfate. The solvent was removed under vacuum and the residue was first purified by a short column (silica gel, DCM) to remove the catalysts, and then further purified by preparative $\mathrm{GPC}$ using $\mathrm{CHCl}_{3}$ at a rate of $14 \mathrm{~mL} / \mathrm{min}$ to afford compound 13 (20 mg, 12\%) as white solid. The NMR spectrum of $\mathbf{1 3}$ is complicated due to existence of multiple cis-/trans- vinyl isomers. HRMS analysis (MALDI, 100\%, $\mathrm{m} / \mathrm{z}$ ) calcd for $\mathrm{C}_{105} \mathrm{H}_{90} \mathrm{O}_{6}: 1446.6732$, found 1446.6724 (error: $-0.5 \mathrm{ppm}$ ).

\section{Compounds $[3,5] \mathrm{CA}$ :}

A mixture of $13(20 \mathrm{mg}, 0.015 \mathrm{mmol})$ and $\mathrm{Bi}(\mathrm{OTf})_{3}(5 \mathrm{mg}, 0.008 \mathrm{mmol})$ in 1,2-dichloroethane (DCE, $40 \mathrm{~mL}$ ) was heated at $90{ }^{\circ} \mathrm{C}$ for 4 hours under $\mathrm{N}_{2}$ atmosphere. After cooling to the room temperature, the reaction was added $\mathrm{H}_{2} \mathrm{O}$ and extracted with DCM. The organic layer was separated, and dried over anhydrous sodium sulfate. The solvent was removed under vacuum and the crude product was recrystallized from methanol and DCM to afford pure compound $[\mathbf{3 , 5}] \mathbf{C A}$ as red solid $(9 \mathrm{mg}, 48 \%)$. The whole processes were conducted in the dark due to the light sensitivity of the final compound. ${ }^{1} \mathrm{H}$ NMR $(500 \mathrm{MHz}$, $373 \mathrm{~K}, \mathrm{CDCl}_{2} \mathrm{CDCl}_{2}$ ): $\delta$ ppm $10.52(\mathrm{~s}, 3 \mathrm{H}), 10.01(\mathrm{~s}, 6 \mathrm{H}), 9.66(\mathrm{~s}, 3 \mathrm{H}), 8.15(\mathrm{~s}, 6 \mathrm{H}), 8.12(\mathrm{~s}$, $3 \mathrm{H}), 7.71(\mathrm{~d}, J=9.1 \mathrm{~Hz}, 6 \mathrm{H}), 7.65(\mathrm{~d}, J=9.3 \mathrm{~Hz}, 6 \mathrm{H}), 2.61(\mathrm{~s}, 9 \mathrm{H}), 1.93(\mathrm{~s}, 18 \mathrm{H}) .{ }^{13} \mathrm{C}$ NMR $\left(125 \mathrm{MHz}, \mathrm{CDCl}_{2} \mathrm{CDCl}_{2}\right.$ ): $\delta$ ppm 137.8, 137.3, 134.1, 131.3, 131.1, 130.3, 129.1, 128.5, 128.4, 128.1, 127.0, 126.9, 124.8, 122.8, 29.6, 21.5, 20.3. HRMS analysis (MALDI, 100\%, $\mathrm{m} / \mathrm{z}$ ) calcd for $\mathrm{C}_{99} \mathrm{H}_{66}: 1254.5159$, found 1254.5156 (error: $-0.3 \mathrm{ppm}$ ). 


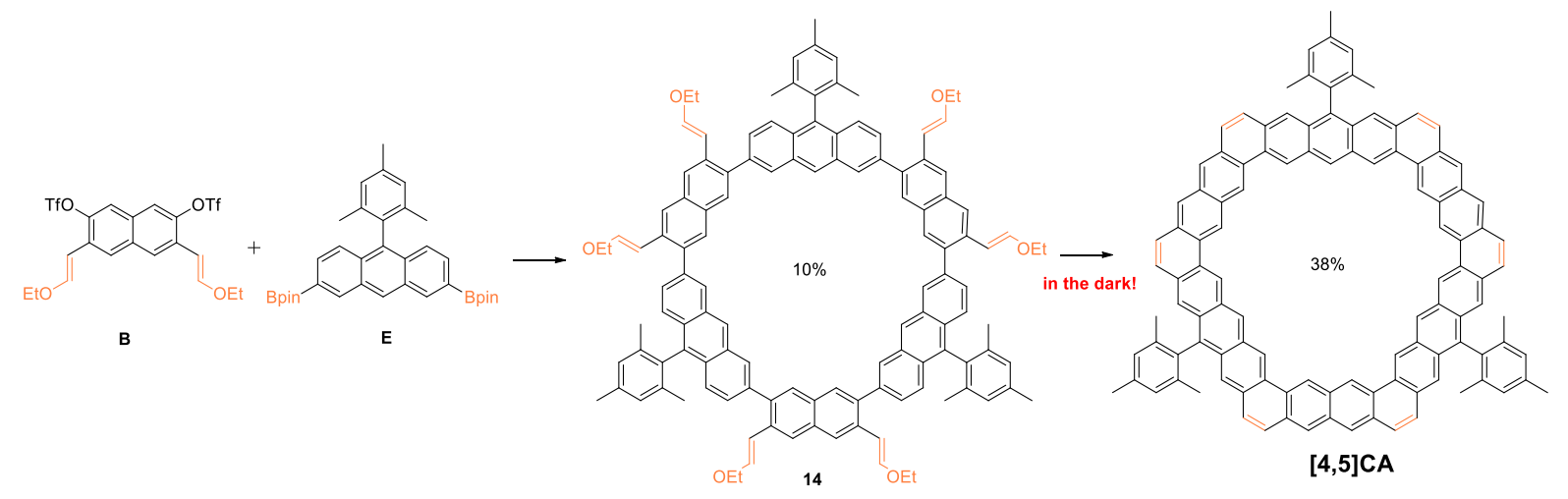

Compounds 14:

A mixture of $\mathbf{B}(206 \mathrm{mg}, 0.365 \mathrm{mmol}), \mathbf{E}(200 \mathrm{mg}, 0.365 \mathrm{mmol}), \mathrm{NaHCO}_{3}$ (2.45 g, 29.2 mmol), THF $(400 \mathrm{~mL})$ and $\mathrm{H}_{2} \mathrm{O}(20 \mathrm{~mL})$ was carefully degassed before the addition of $\mathrm{Pd}_{2}(\mathrm{dba})_{3}(33.4 \mathrm{mg}, 0.0365 \mathrm{mmol})$ and $\left[(t-\mathrm{Bu})_{3} \mathrm{PH}\right] \mathrm{BF}_{4}(42.4 \mathrm{mg}, 0.146 \mathrm{mmol})$. The mixture was stirred and heated at $80{ }^{\circ} \mathrm{C}$ for 3 days under $\mathrm{N}_{2}$ atmosphere. The organic solvent was removed under the reduced pressure, and then $\mathrm{H}_{2} \mathrm{O}$ and DCM were added. The organic layer was separated, and dried over anhydrous sodium sulfate. The solvent was removed under vacuum and the residue was first purified by a short column (silica gel, DCM) to remove the catalysts, and then further purified by preparative $\mathrm{GPC}$ using $\mathrm{CHCl}_{3}$ at a rate of $14 \mathrm{~mL} / \mathrm{min}$ to afford compound 14 (18 mg, 10\%) as white solid. The intermediate 14 was directly used in the next step without further purification due to it contained some other impurities of linear oligomers with similar molecule size during the GPC separation. ${ }^{1} \mathrm{H}$ NMR $(400 \mathrm{MHz}, 298 \mathrm{~K}$, $\left.\mathrm{CD}_{2} \mathrm{Cl}_{2}\right): \delta \mathrm{ppm} 8.72(\mathrm{~s}, 3 \mathrm{H}), 8.30(\mathrm{~s}, 6 \mathrm{H}), 7.98(\mathrm{~s}, 6 \mathrm{H}), 7.87(\mathrm{~s}, 6 \mathrm{H}), 7.62\left(\mathrm{dd},{ }^{3} \mathrm{~J}=9.0 \mathrm{~Hz},{ }^{4} J\right.$ $=1.6 \mathrm{~Hz}, 6 \mathrm{H}), 7.48(\mathrm{~d}, J=8.9 \mathrm{~Hz}, 6 \mathrm{H}), 7.12(\mathrm{~s}, 6 \mathrm{H}), 7.07(\mathrm{~d}, J=12.7 \mathrm{~Hz}, 6 \mathrm{H}), 6.19(\mathrm{~d}, J=$ $12.6 \mathrm{~Hz}, 6 \mathrm{H}), 3.87-3.82(\mathrm{t}, J=8 \mathrm{~Hz}, 12 \mathrm{H}), 2.44(\mathrm{~s}, 9 \mathrm{H}), 1.84-1.72(\mathrm{~m}, 18 \mathrm{H}), 1.58-1.54(\mathrm{~m}$, $18 \mathrm{H})$. Clean ${ }^{13} \mathrm{C}$ NMR spectrum could not be obtained due to the impurities. HRMS analysis (MALDI, $100 \%, m / z$ ) calcd for $\mathrm{C}_{123} \mathrm{H}_{108} \mathrm{O}_{6}$ : 1680.8140, found 1680.8126 (error: -0.8 ppm).

\section{Compounds $[4,5] \mathrm{CA}$ :}

A mixture of $14(35 \mathrm{mg}, 0.0208 \mathrm{mmol})$ and $\mathrm{Bi}(\mathrm{OTf})_{3}(5 \mathrm{mg}, 0.008 \mathrm{mmol})$ in 1,2-dichloroethane (DCE, $40 \mathrm{~mL}$ ) was heated at $90{ }^{\circ} \mathrm{C}$ for 4 hours under $\mathrm{N}_{2}$ atmosphere. After cooling to the room temperature, the reaction was added $\mathrm{H}_{2} \mathrm{O}$ and extracted with DCM. The organic layer was separated, and dried over anhydrous sodium sulfate. The solvent was removed under vacuum and the crude product was recrystallized from methanol and DCM to afford pure compound [4,5]CA as red solid (11 $\mathrm{mg}, 38 \%)$. The whole processes were conducted in the dark due to the light sensitivity of the final compound. ${ }^{1} \mathrm{H}$ NMR $(500 \mathrm{MHz}$, $\left.373 \mathrm{~K}, \mathrm{CDCl}_{2} \mathrm{CDCl}_{2}\right)$ : $\delta$ ppm $9.83(\mathrm{~s}, 6 \mathrm{H}), 9.75(\mathrm{~s}, 6 \mathrm{H}), 9.41(\mathrm{~s}, 3 \mathrm{H}), 8.26(\mathrm{~s}, 6 \mathrm{H}), 7.94(\mathrm{~s}, 6 \mathrm{H})$, $7.52(\mathrm{~d}, J=9.6 \mathrm{~Hz}, 6 \mathrm{H}), 7.49(\mathrm{~d}, J=9.2 \mathrm{~Hz}, 6 \mathrm{H}), 7.26(\mathrm{~s}, 6 \mathrm{H}), 2.60(\mathrm{~s}, 9 \mathrm{H}), 1.92(\mathrm{~s}, 18 \mathrm{H})$. The ${ }^{13} \mathrm{C}$ NMR spectrum could not be obtained due to the limited solubility, even in THF- $d_{8}$. HRMS analysis (MALDI, $100 \%, m / z)$ calcd for $\mathrm{C}_{111} \mathrm{H}_{72}: 1404.5629$, found 1404.5628 (error: $-0.0 \mathrm{ppm})$. 


\section{Additional spectra}
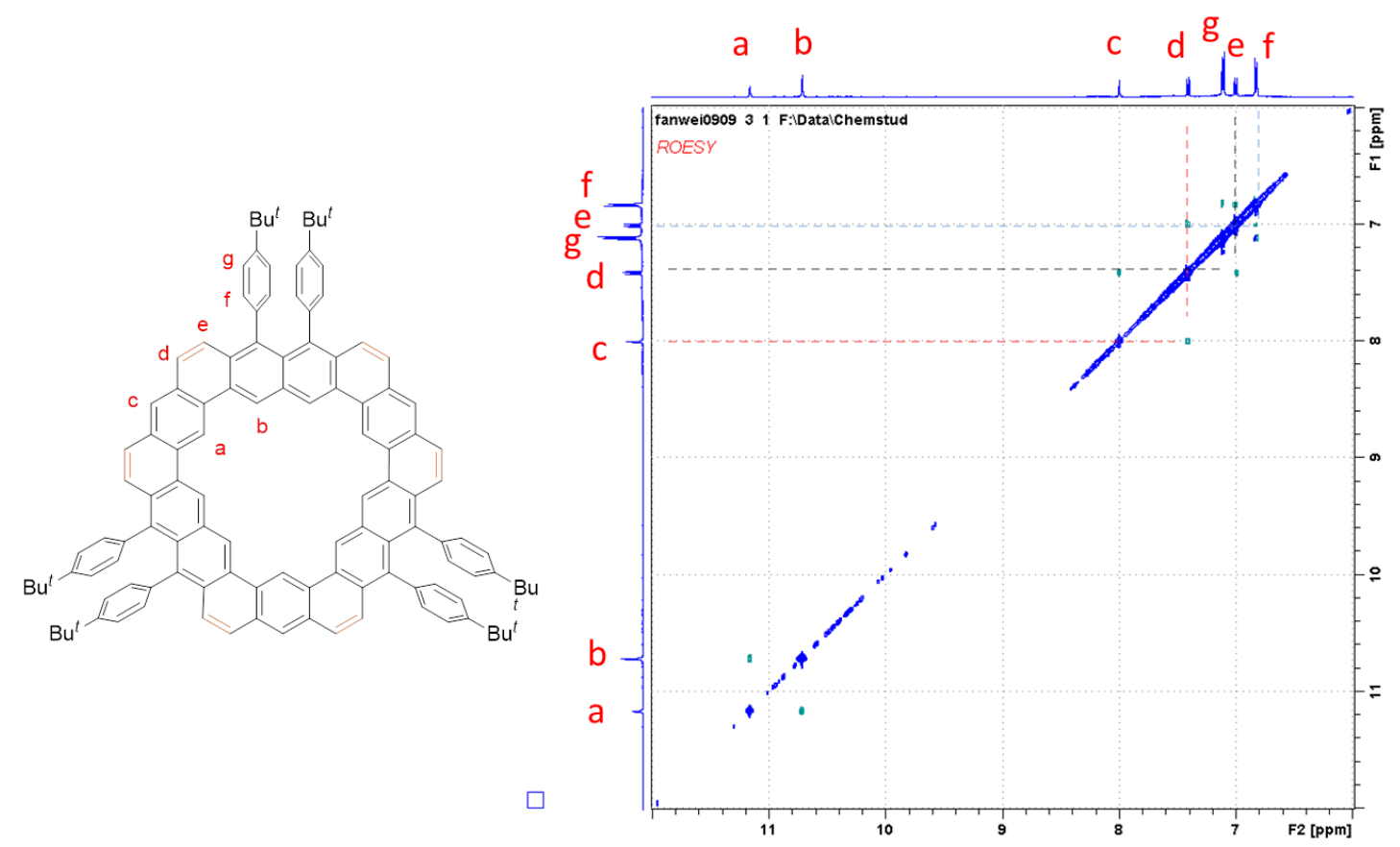

Figure S1. 2D ROESY NMR spectrum of $[\mathbf{3 , 4}] \mathbf{C A}-1$ in $\mathrm{CD}_{2} \mathrm{Cl}_{2}(500 \mathrm{MHz})$ at $298 \mathrm{~K}$ showing aromatic/aromatic correlations.

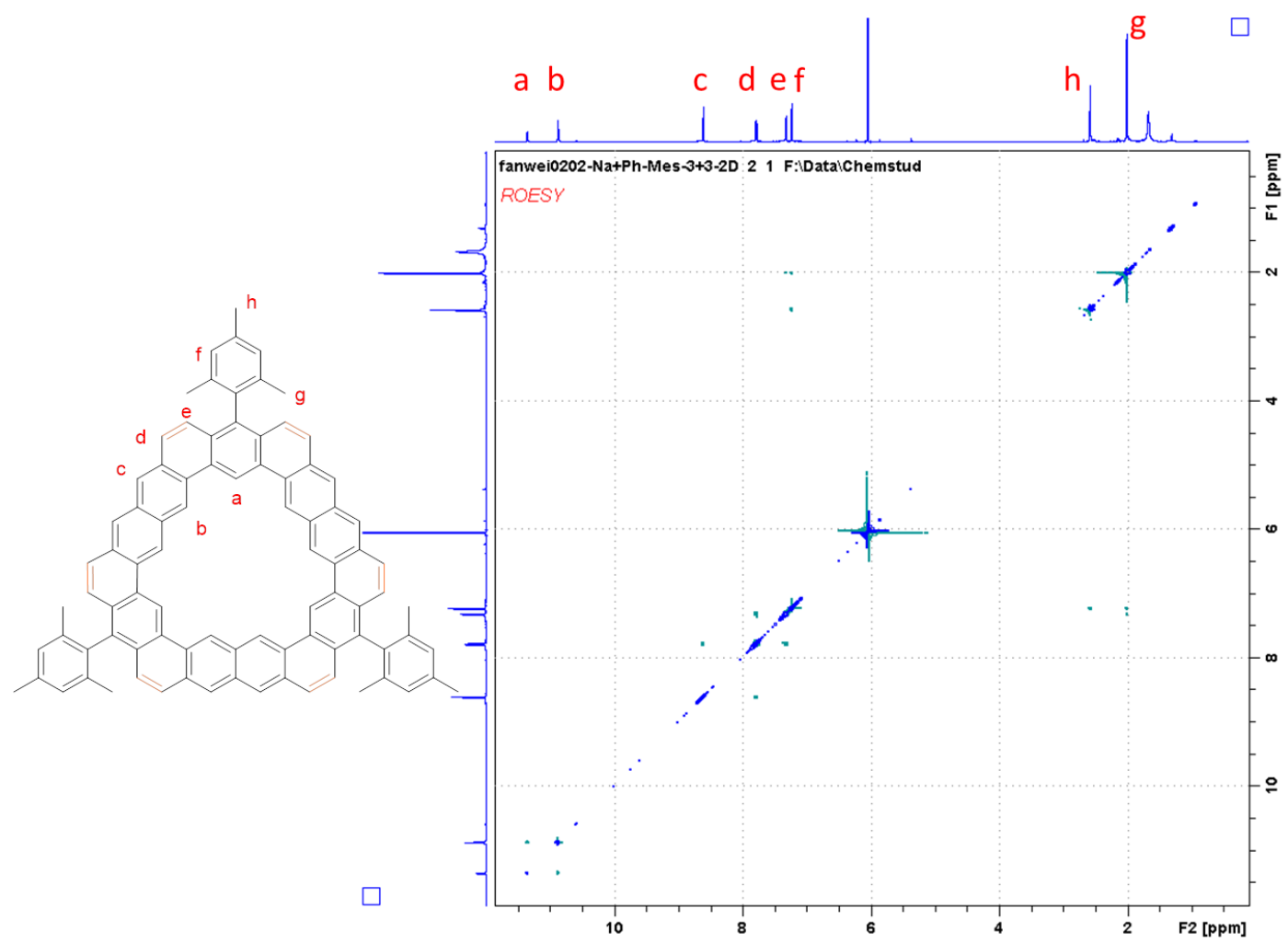

Figure S2. 2D ROESY NMR spectrum of [3,4]CA-2 in $\mathrm{CDCl}_{2} \mathrm{CDCl}_{2}(500 \mathrm{MHz})$ at $298 \mathrm{~K}$ showing correlations. 


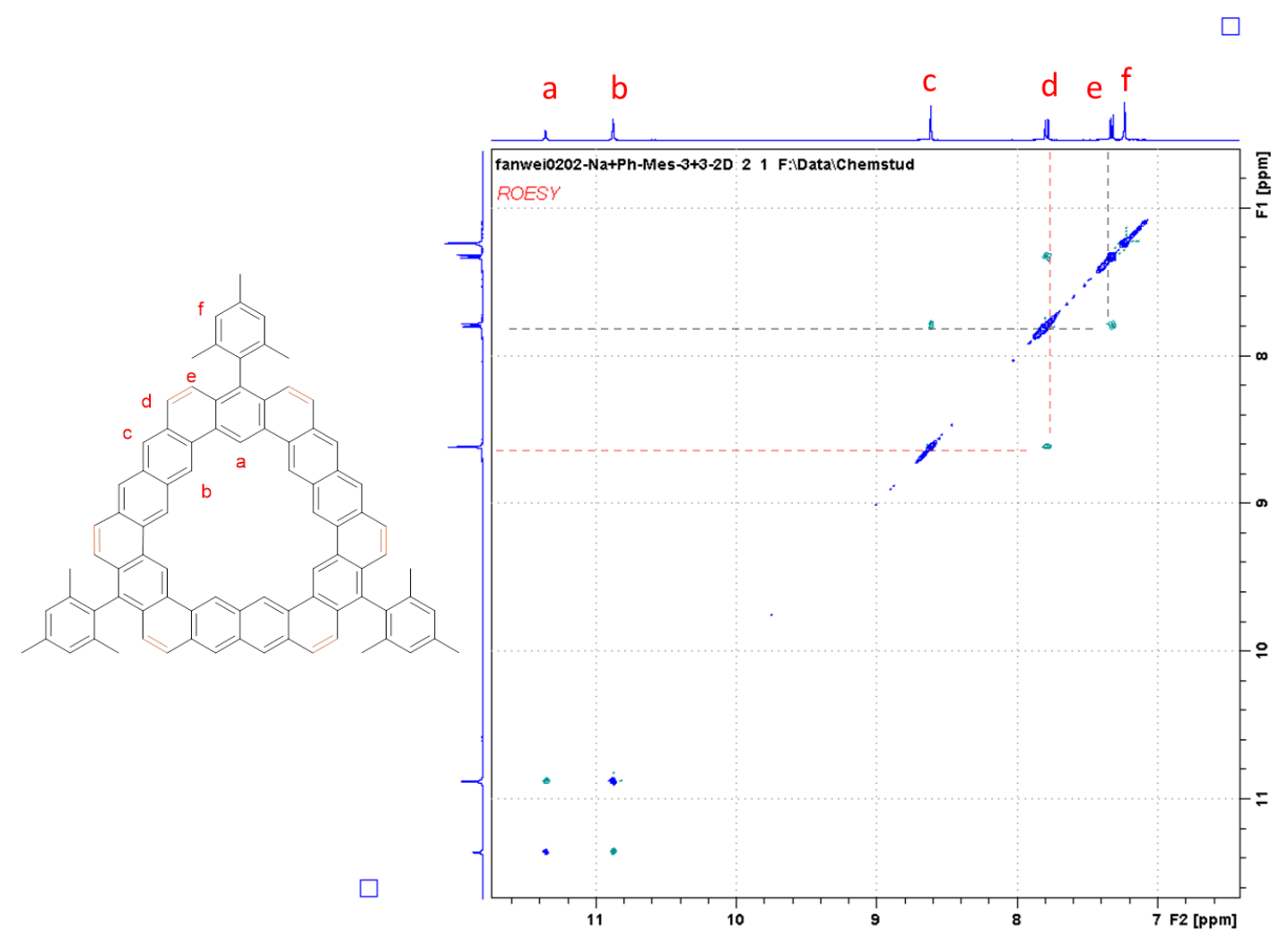

Figure S3. Partial 2D ROESY NMR spectrum of [3,4]CA-2 in $\mathrm{CDCl}_{2} \mathrm{CDCl}_{2}(500 \mathrm{MHz})$ at $298 \mathrm{~K}$ showing aromatic/aromatic correlations.

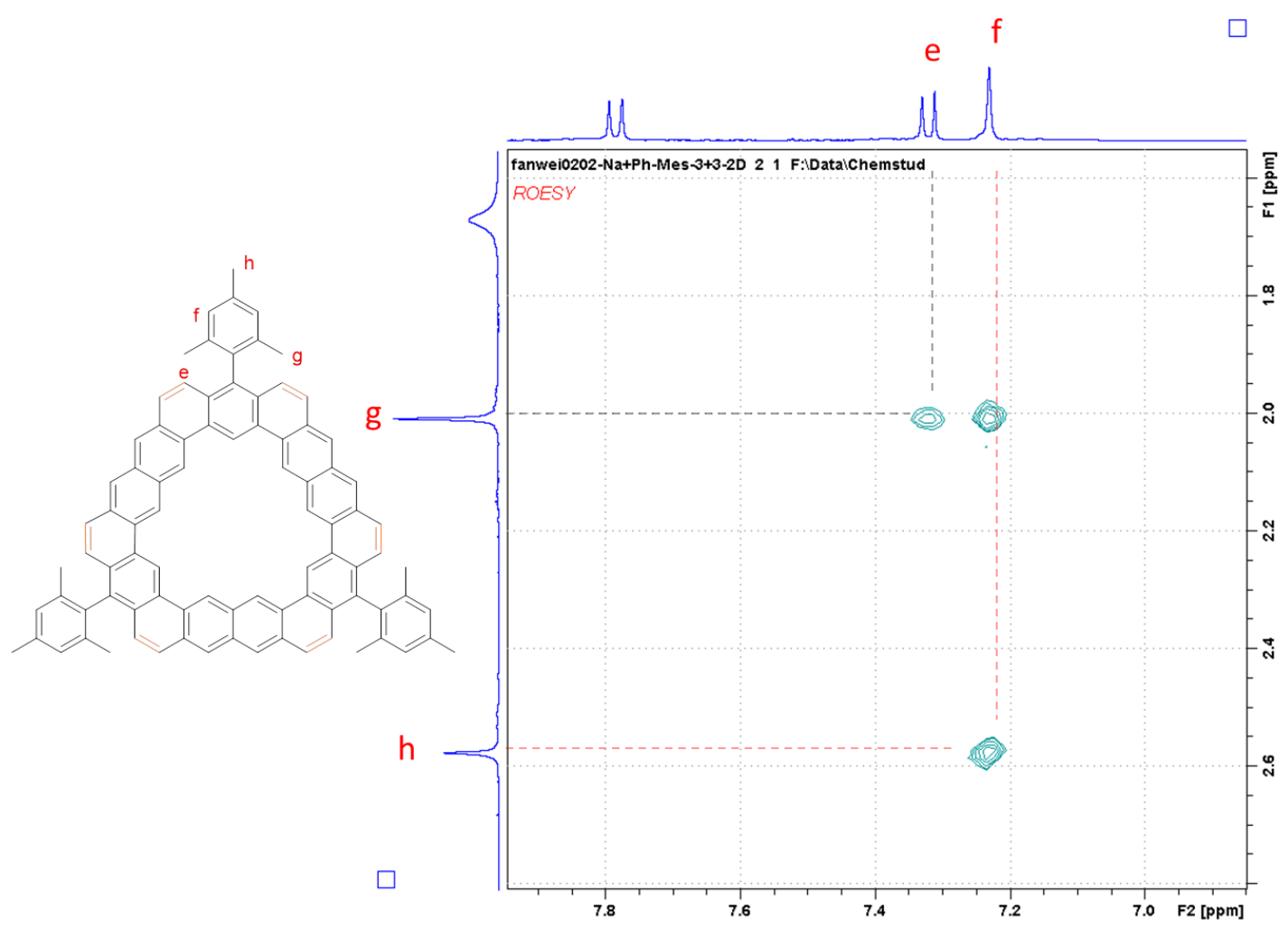

Figure S4. Partial 2D ROESY NMR spectrum of [3,4]CA-2 in $\mathrm{CDCl}_{2} \mathrm{CDCl}_{2}(500 \mathrm{MHz})$ at $298 \mathrm{~K}$ showing aromatic/aliphatic correlations. 


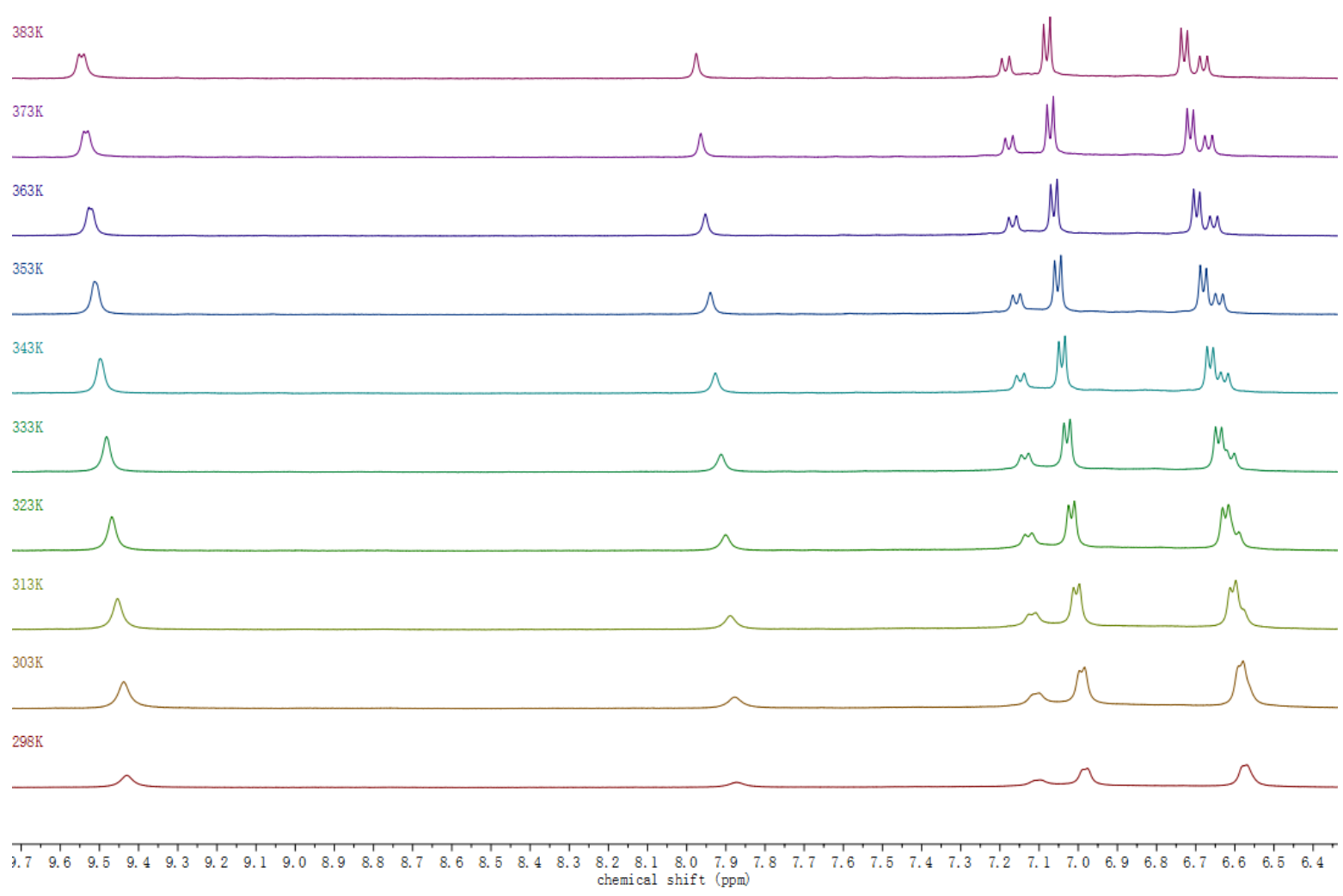

Figure S5. Partial (aromatic region) VT ${ }^{1} \mathrm{H}$ NMR spectrum of $[4,4] \mathrm{CA}$ in $\mathrm{CDCl}_{2} \mathrm{CDCl}_{2}(500$ $\mathrm{MHz}$ ). The signal broadening at low temperatures was due to aggregation.
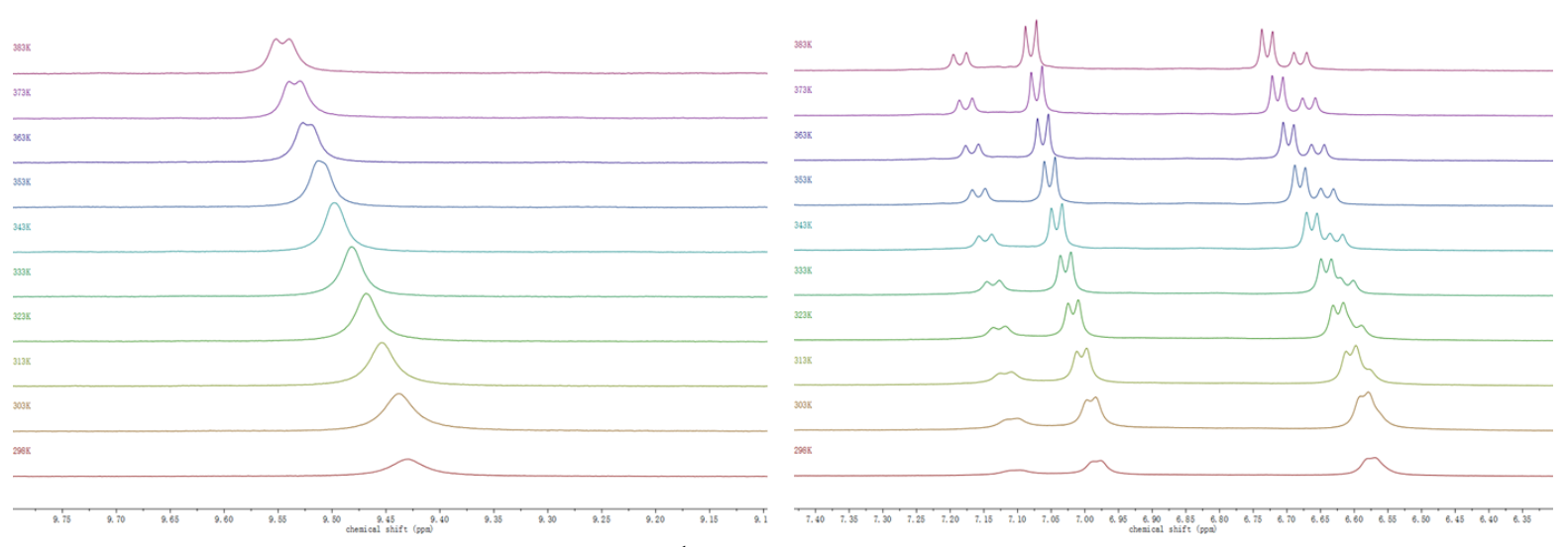

Figure S6. Partial (aromatic region) VT ${ }^{1} \mathrm{H}$ NMR spectrum of $[\mathbf{4 , 4}] \mathrm{CA}$ in $\mathrm{CDCl}_{2} \mathrm{CDCl}_{2}$ (500 $\mathrm{MHz}$ ). The signal broadening at low temperatures was due to aggregation. 


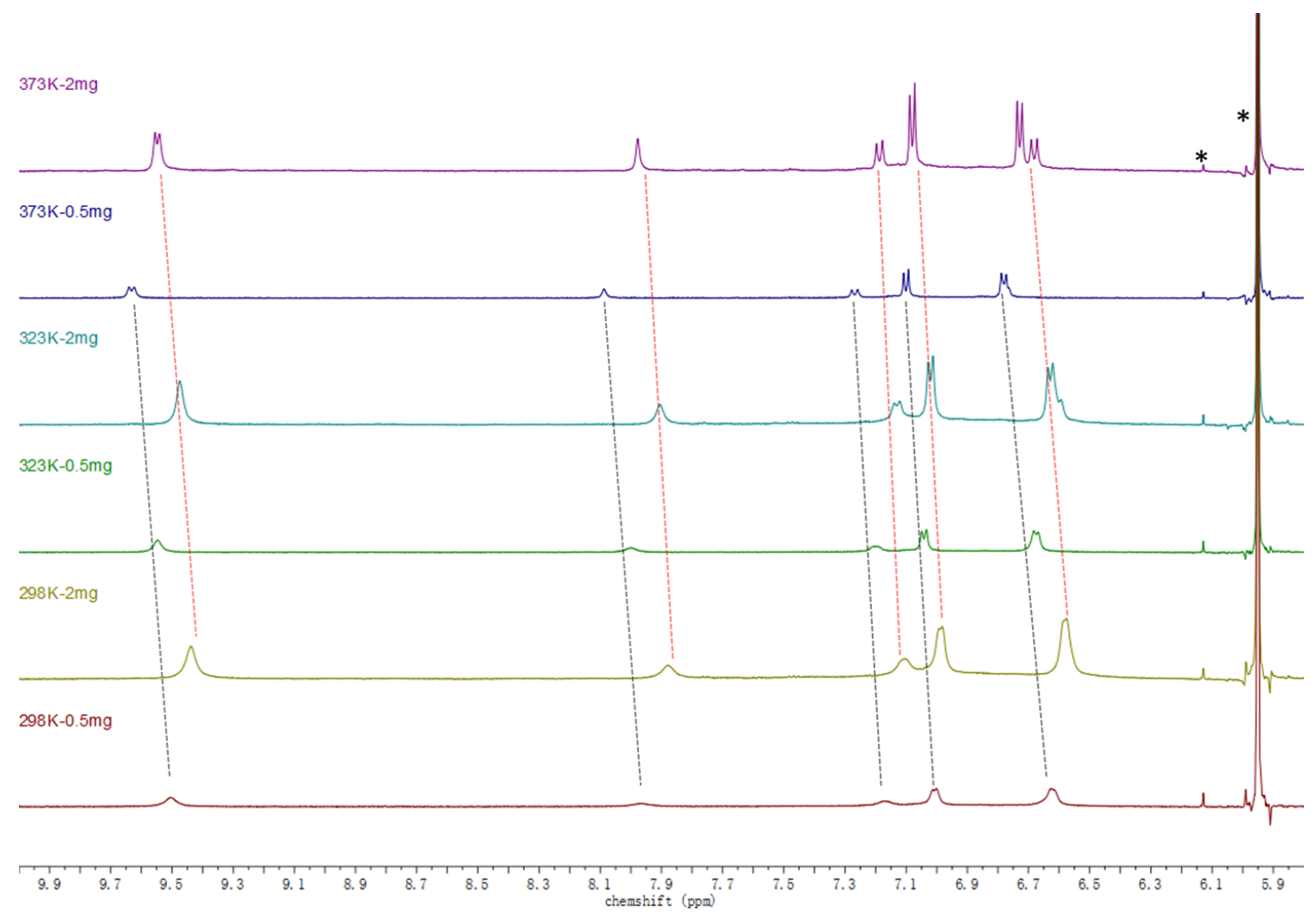

Figure S7. VT ${ }^{1} \mathrm{H}$ NMR spectra (aromatic region) of $[4,4] \mathrm{CA}$ in $\mathrm{CDCl}_{2} \mathrm{CDCl}_{2}(500 \mathrm{MHz})$ under different concentrations $\left(5.9 \times 10^{-4} \mathrm{M}\right.$ for the peaks labelled by the black dash lines, $2.36 \times 10^{-3} \mathrm{M}$ for the peaks labelled by the red dash lines). The upfield shift of the signals at higher concentration was due to aggregation. The peaks labeled with asterisk are from the deuterated solvent.

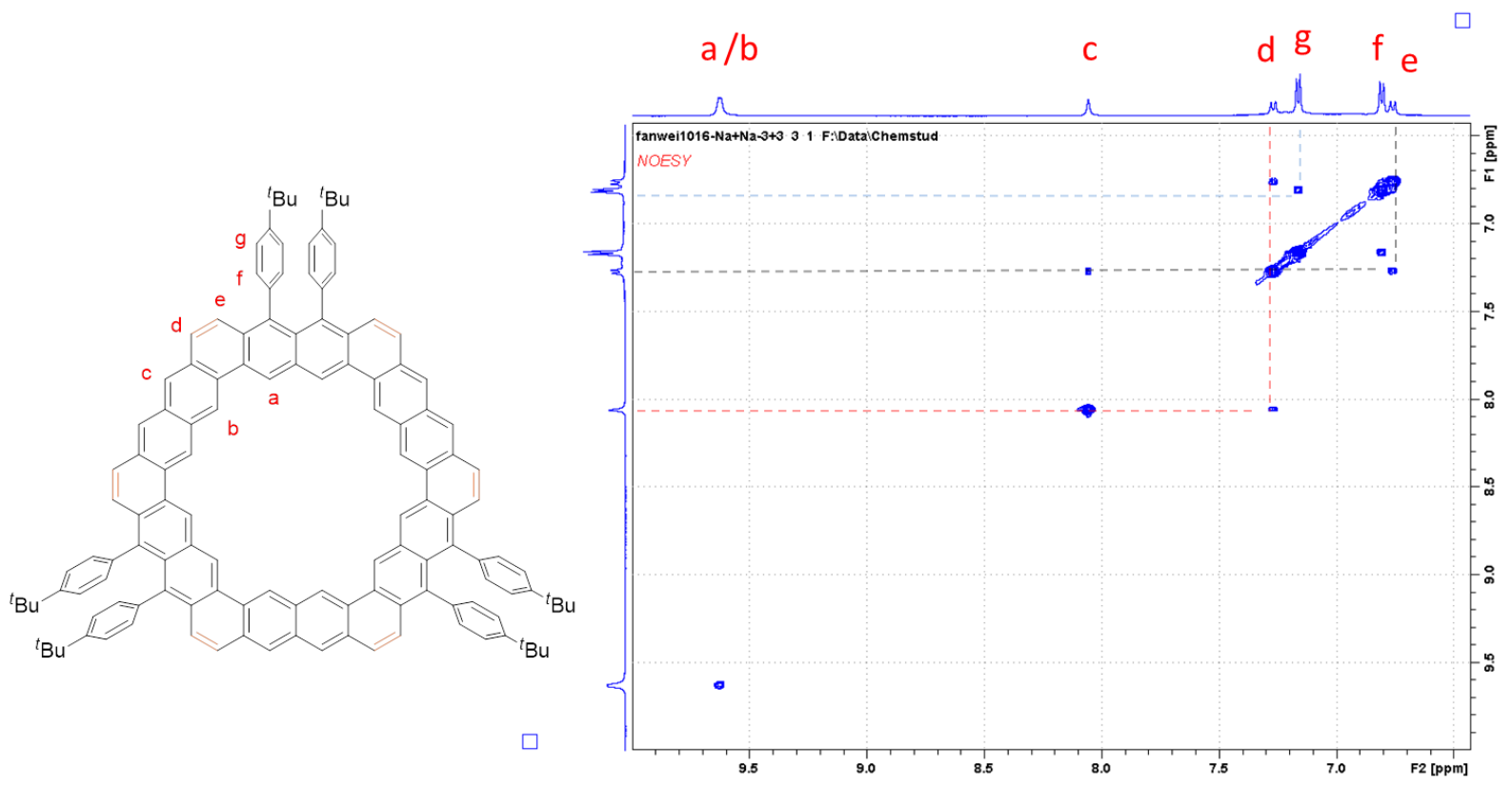

Figure S8. 2D ROESY NMR spectrum of [4,4]CA in $\mathrm{CDCl}_{2} \mathrm{CDCl}_{2}(500 \mathrm{MHz})$ at $373 \mathrm{~K}$ showing aromatic/aromatic correlations. 


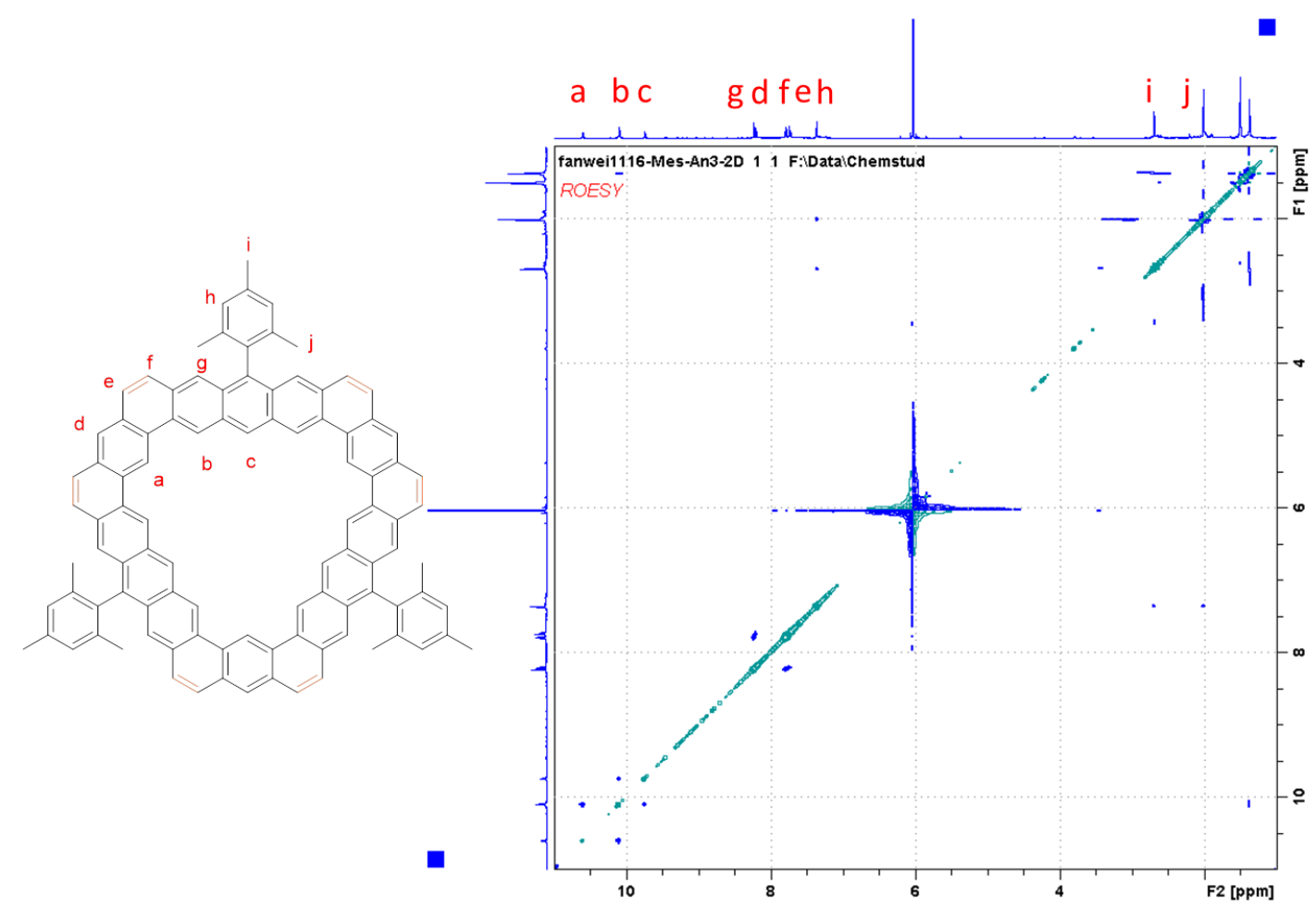

Figure S9. 2D ROESY NMR spectrum of [3,5]CA in $\mathrm{CDCl}_{2} \mathrm{CDCl}_{2}(500 \mathrm{MHz})$ at $373 \mathrm{~K}$ showing correlations.

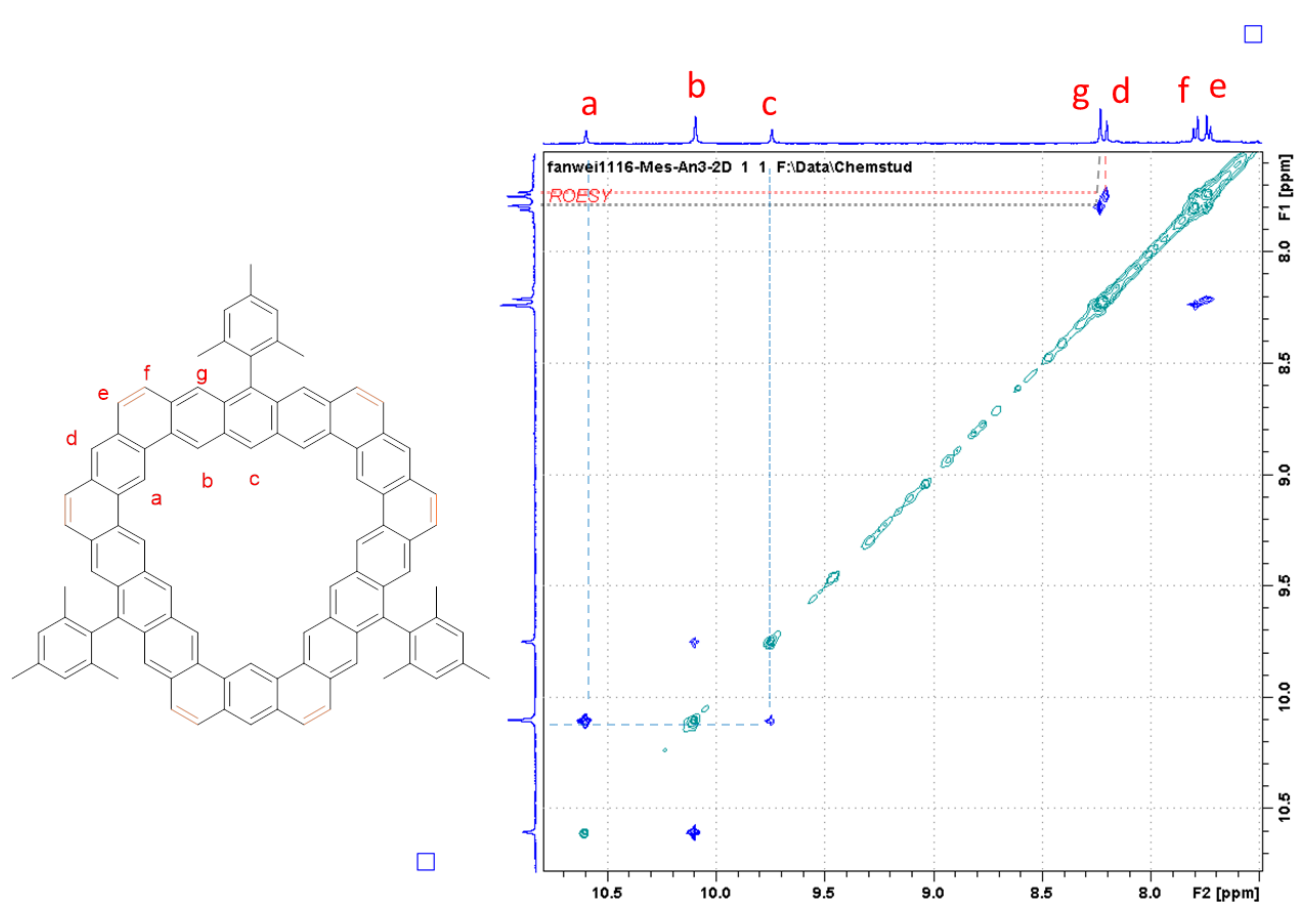

Figure S10. Partial 2D ROESY NMR spectrum of [3,5]CA in $\mathrm{CDCl}_{2} \mathrm{CDCl}_{2}(500 \mathrm{MHz})$ at $373 \mathrm{~K}$ showing aromatic/aromatic correlations. 


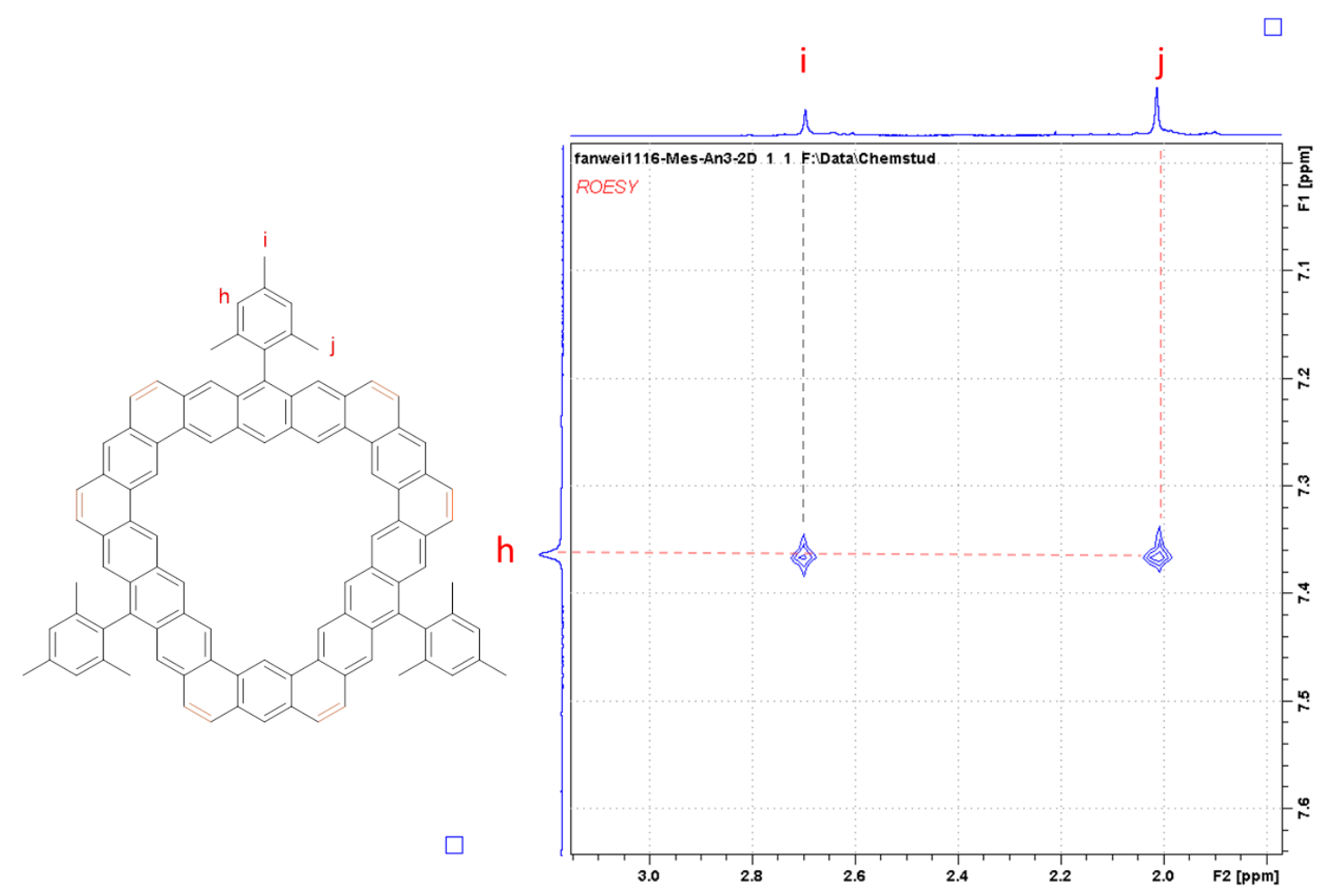

Figure S11. Partial 2D ROESY NMR spectrum of [3,5]CA in $\mathrm{CDCl}_{2} \mathrm{CDCl}_{2}(500 \mathrm{MHz})$ at $373 \mathrm{~K}$ showing aromatic/aliphatic correlations.

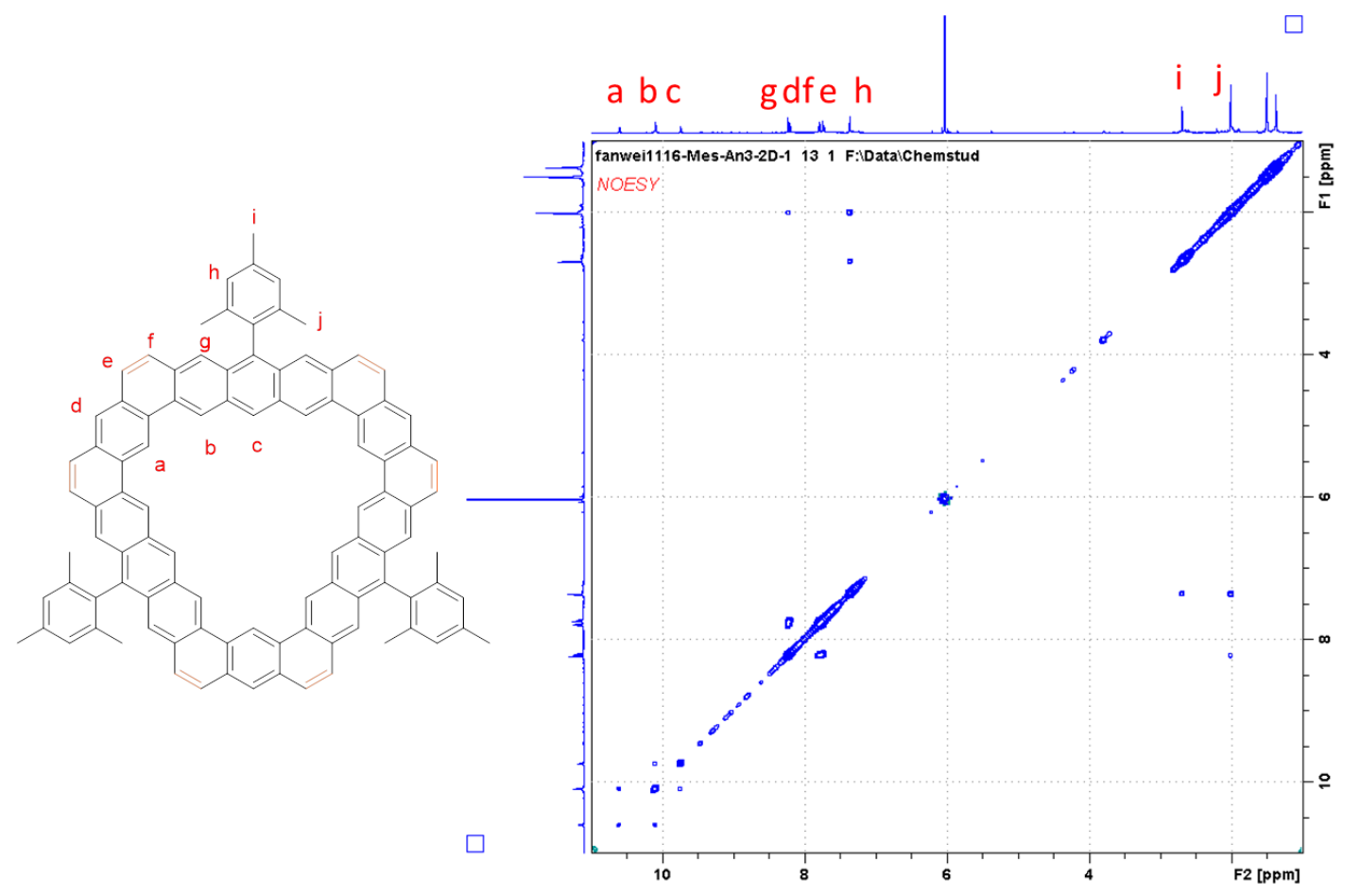

Figure S12. 2D NOESY NMR spectrum of $[\mathbf{3 , 5}] \mathbf{C A}$ in $\mathrm{CDCl}_{2} \mathrm{CDCl}_{2}(500 \mathrm{MHz})$ at $373 \mathrm{~K}$ showing correlations. 


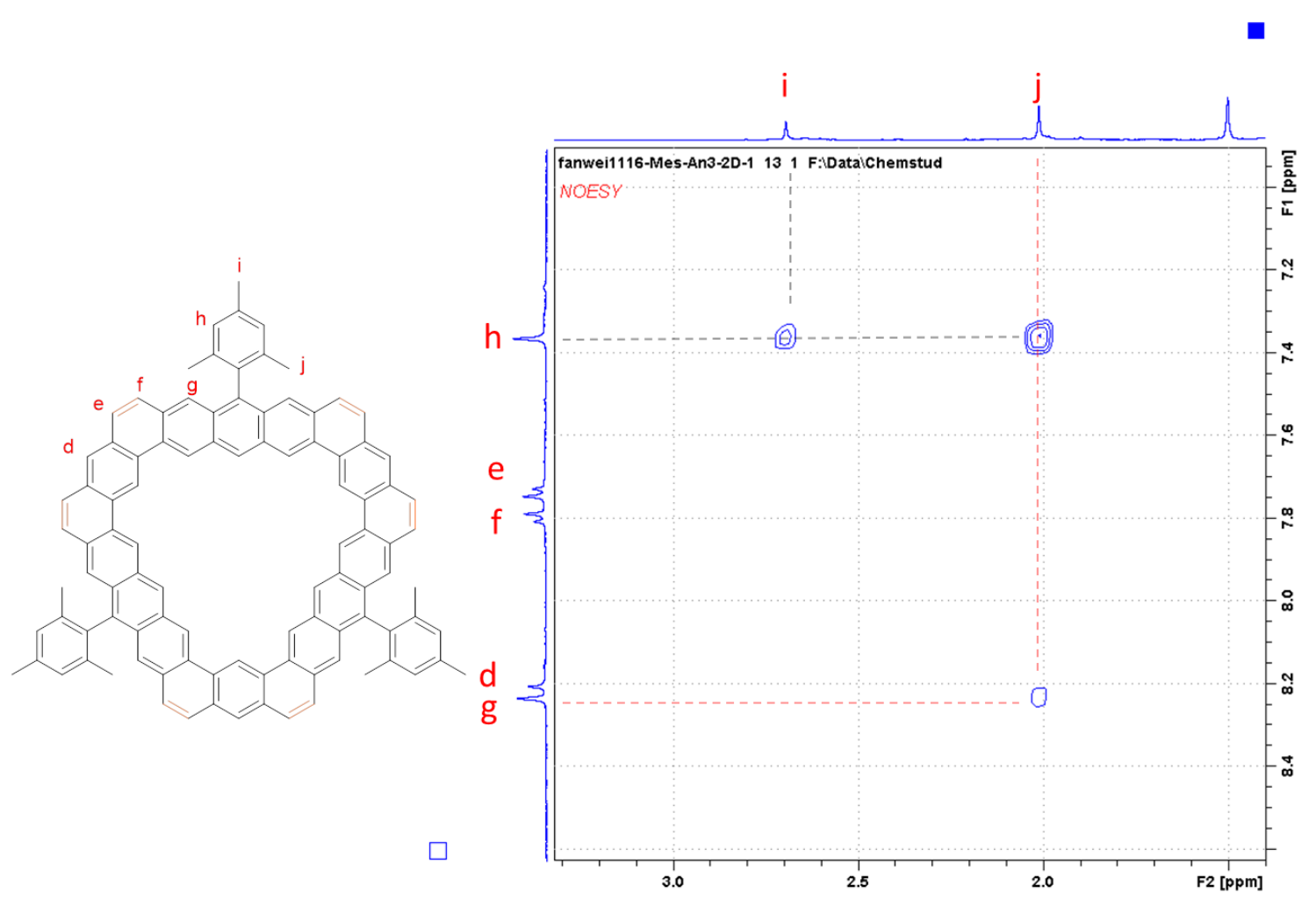

Figure S13. Partial 2D NOESY NMR spectrum of [3,5]CA in $\mathrm{CDCl}_{2} \mathrm{CDCl}_{2}(500 \mathrm{MHz})$ at $373 \mathrm{~K}$ showing aromatic/aliphatic correlations.

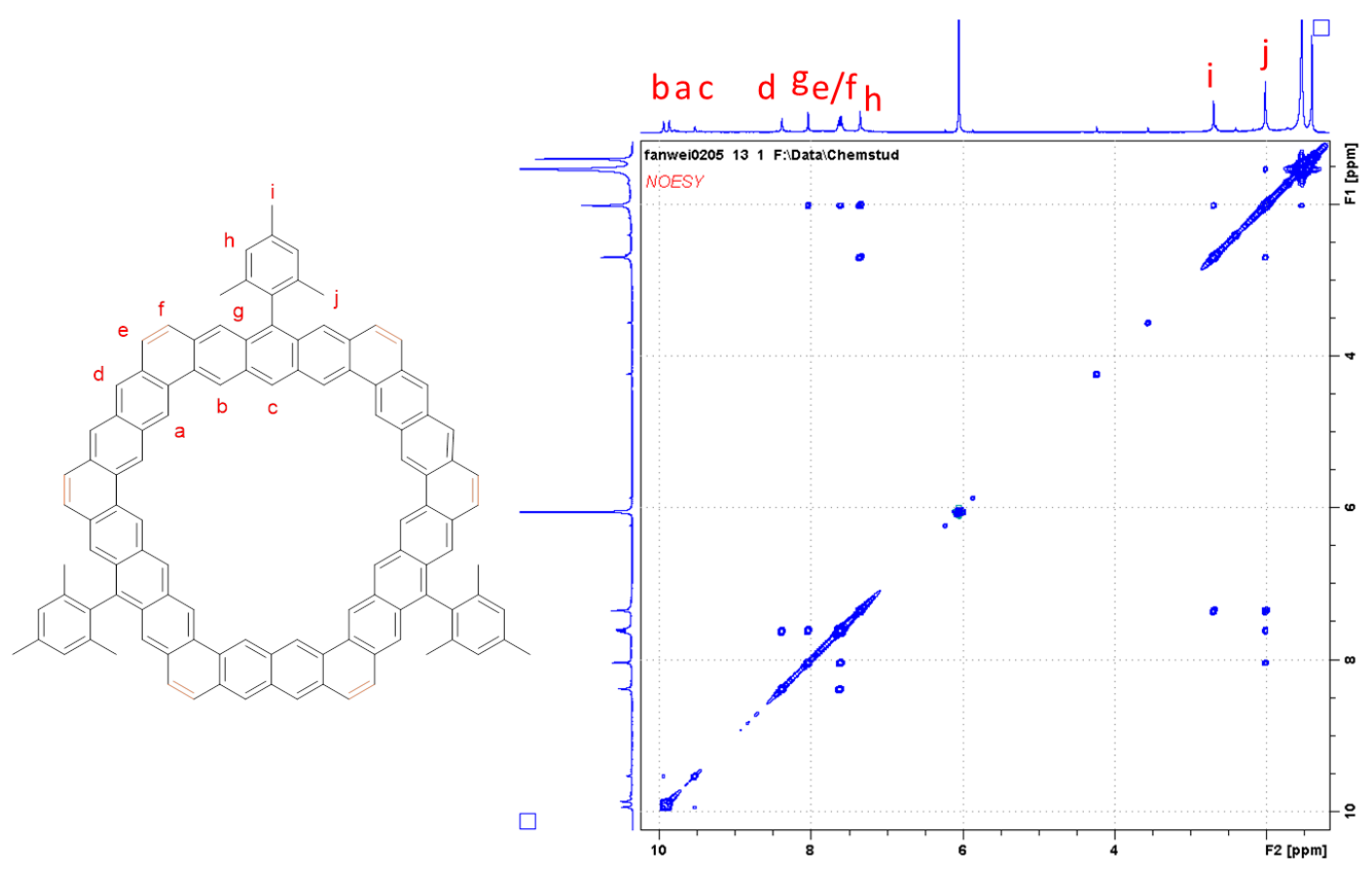

Figure S14. 2D NOESY NMR spectrum of $[4,5] \mathbf{C A}$ in $\mathrm{CDCl}_{2} \mathrm{CDCl}_{2}(500 \mathrm{MHz})$ at $373 \mathrm{~K}$ showing correlations. 


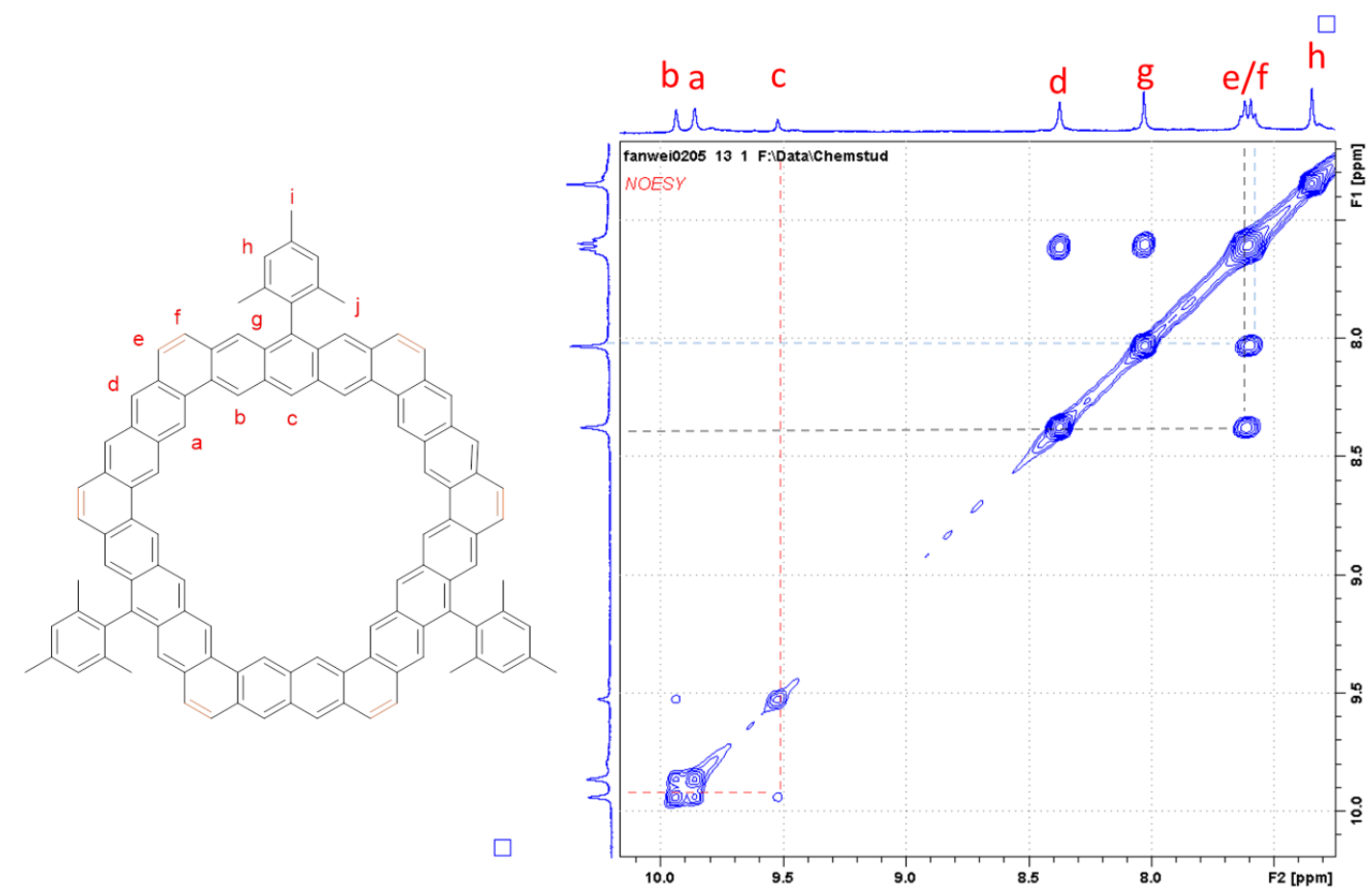

Figure S15. Partial 2D NOESY NMR spectrum of [4,5]CA in $\mathrm{CDCl}_{2} \mathrm{CDCl}_{2}(500 \mathrm{MHz})$ at $373 \mathrm{~K}$ showing aromatic/aromatic correlations.

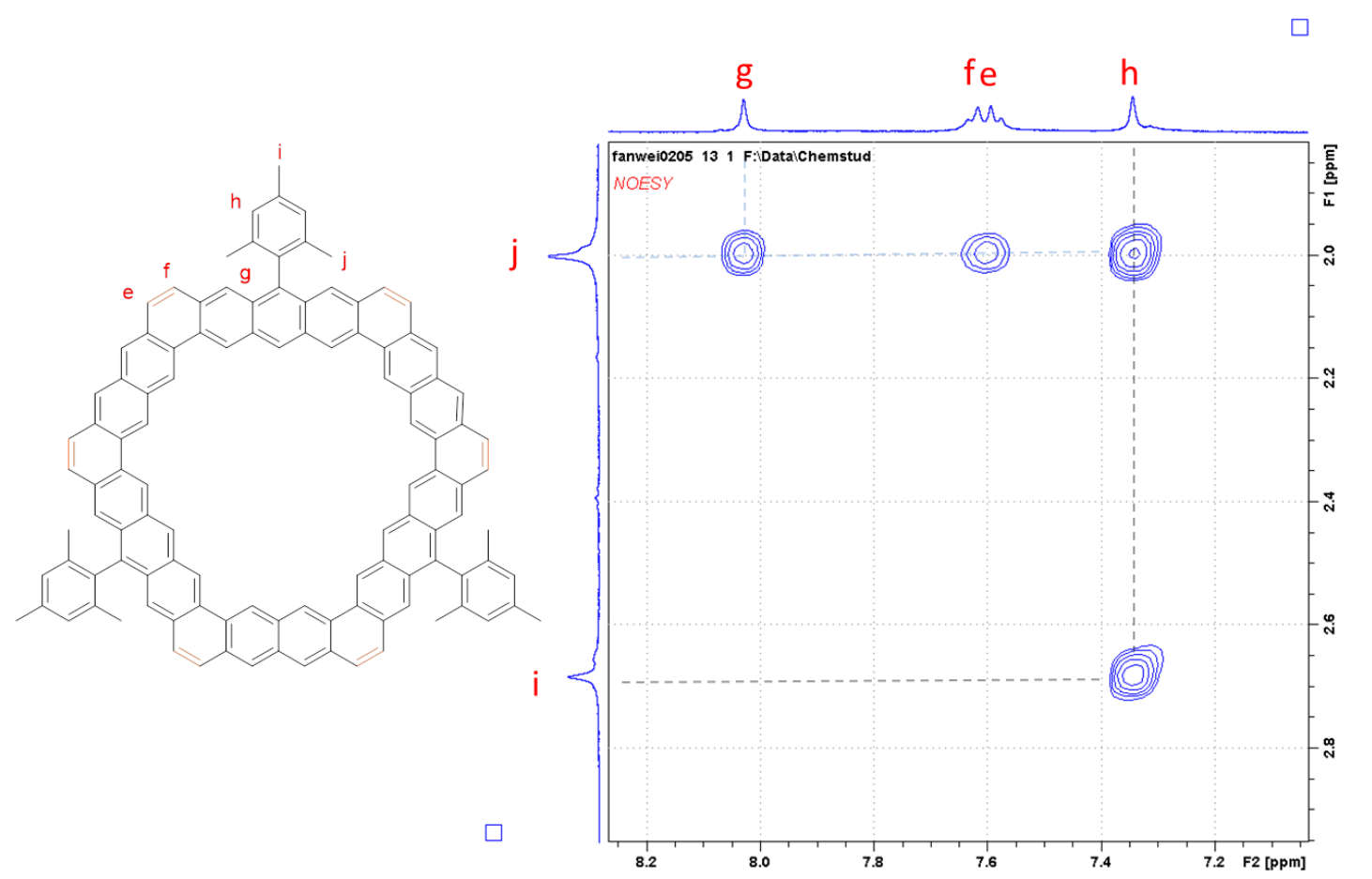

Figure S16. Partial 2D NOESY NMR spectrum of [4,5]CA in $\mathrm{CDCl}_{2} \mathrm{CDCl}_{2}(500 \mathrm{MHz})$ at $373 \mathrm{~K}$ showing aromatic/aliphatic correlations. 


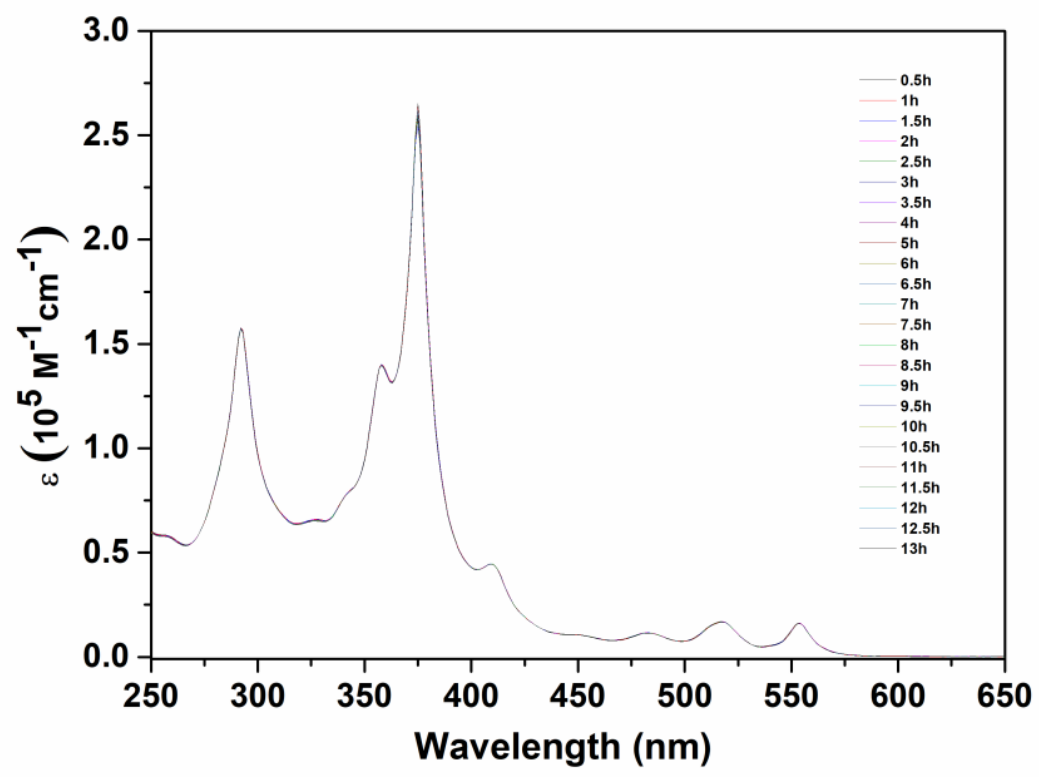

Figure S17. Time-dependent UV/vis spectra of $[3,5]$ CA exposed to air and dark measured in THF $\left(1 \times 10^{-5} \mathrm{M}\right)$.

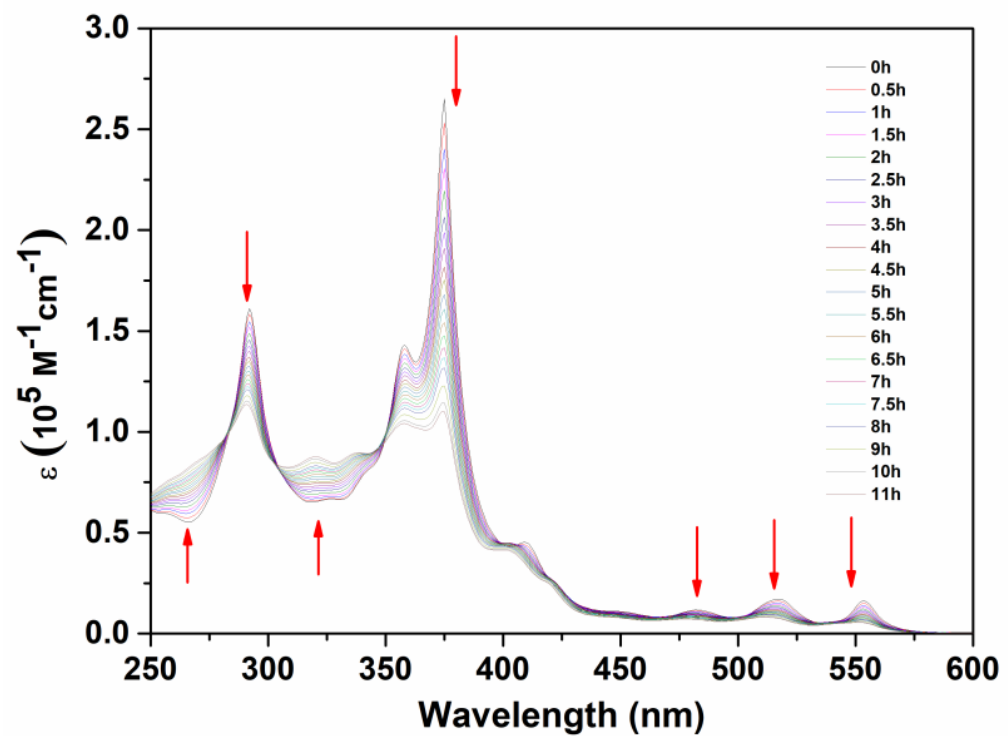

Figure S18. Time-dependent UV/vis spectra of $[3,5]$ CA exposed to air and ambient light measured in THF $\left(1 \times 10^{-5} \mathrm{M}\right)$. 


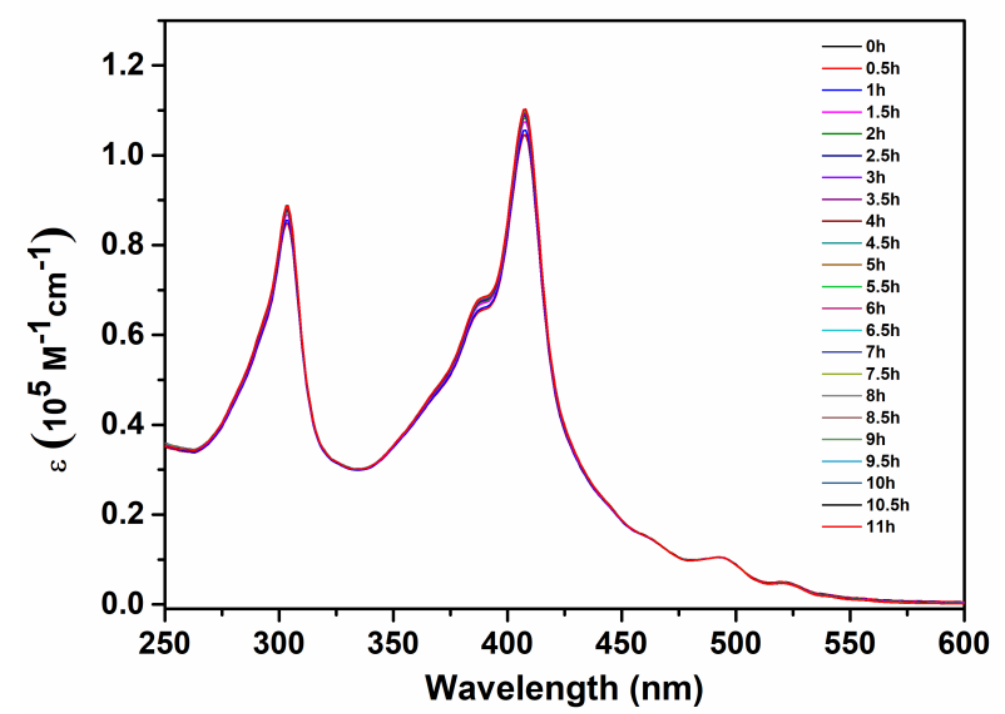

Figure S19. Time-dependent UV/vis spectra of [4,5]CA exposed to air and dark measured in THF $\left(1 \times 10^{-5} \mathrm{M}\right)$.

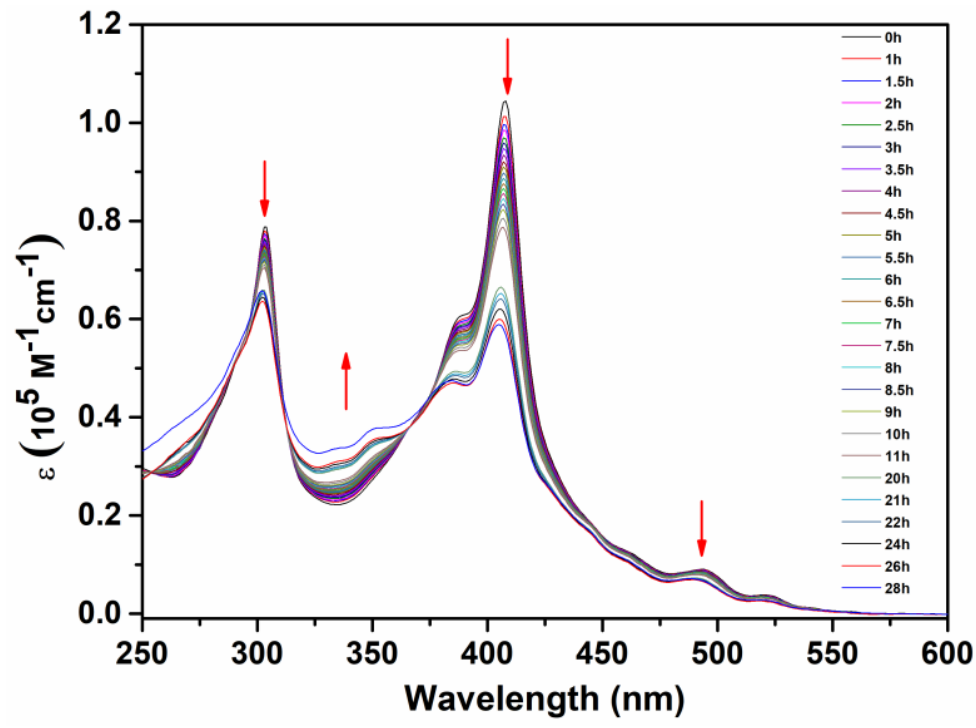

Figure S20. Time-dependent UV/vis spectra of $[4,5]$ CA exposed to air and ambient light measured in THF $\left(1 \times 10^{-5} \mathrm{M}\right)$. 


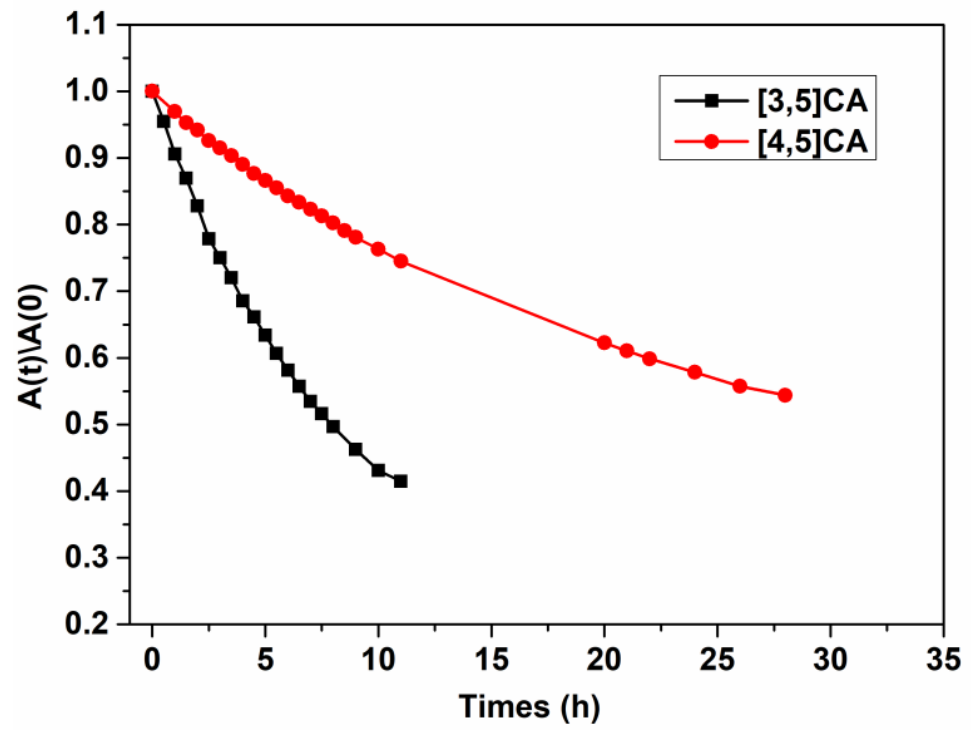

Figure S21. Decay profiles of the characteristic absorption band of [3,5]CA at $375 \mathrm{~nm}$ and $[\mathbf{4 , 5}] \mathrm{CA}$ at $408 \mathrm{~nm}$.

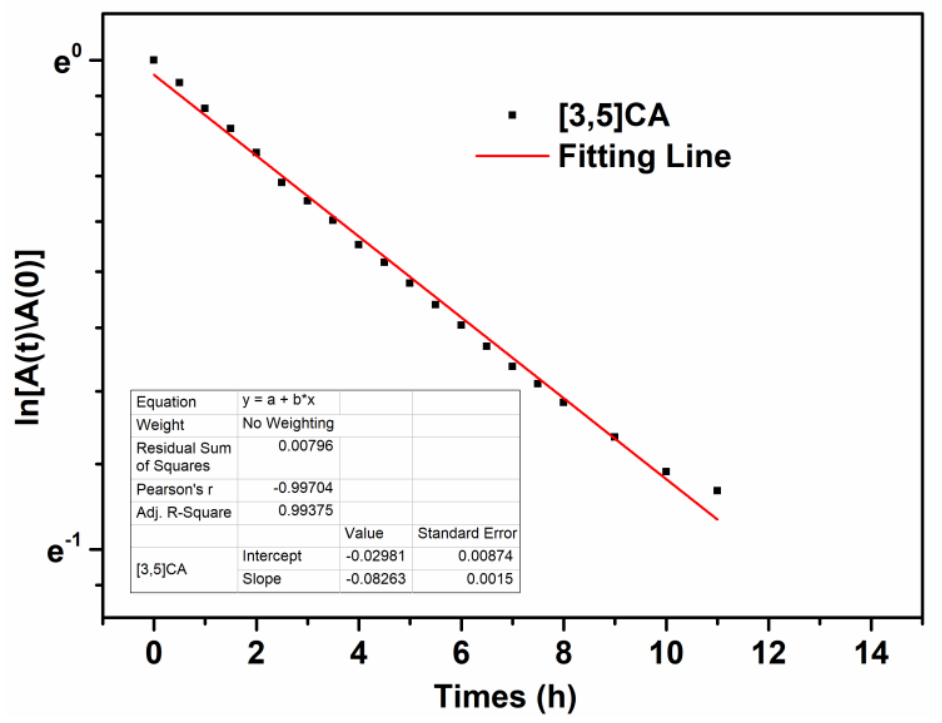

Figure S22. Kinetic fitting for [3,5]CA of the photoxidation in the first order. 


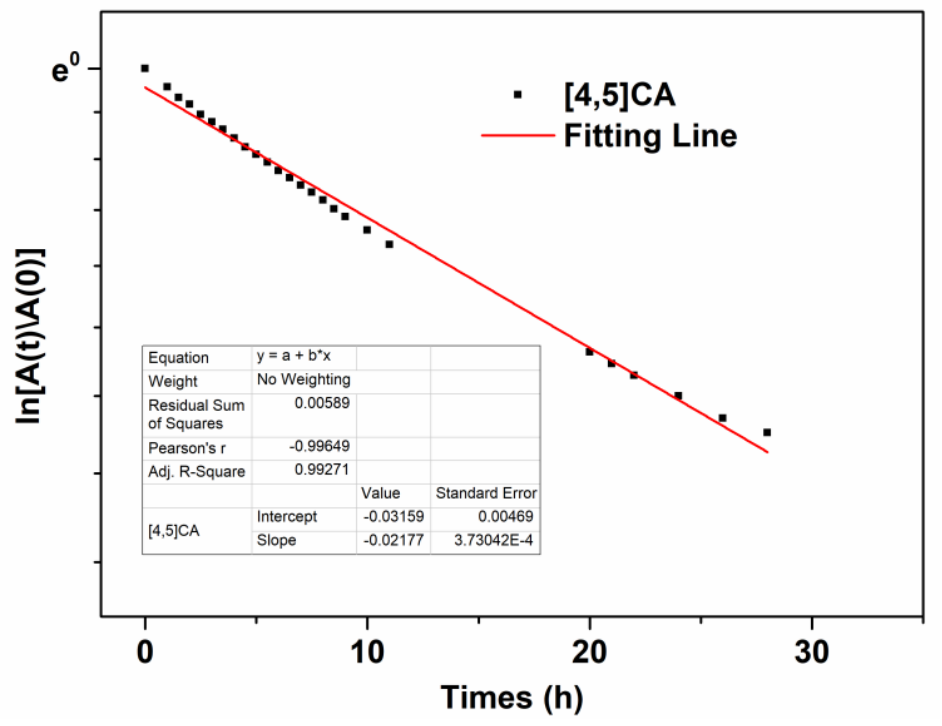

Figure S23. Kinetic fitting for $[4,5]$ CA of the photoxidation in the first order.

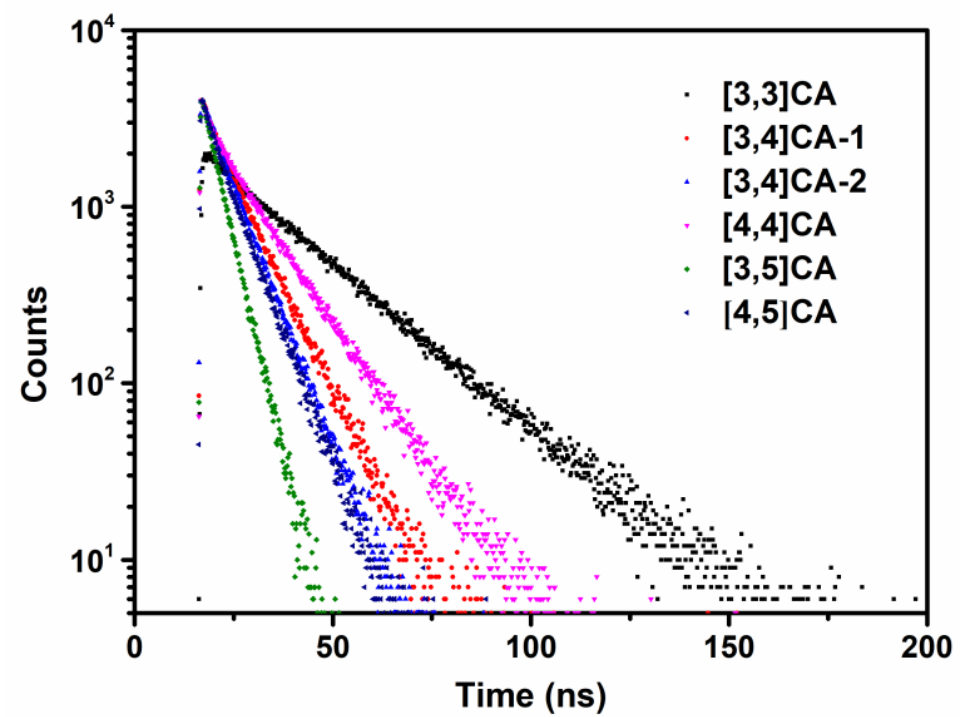

Figure S24. Time-resolved fluorescence decay profiles of $[3,3] \mathbf{C A}\left(\lambda_{\mathrm{exc}}=340 \mathrm{~nm}, \lambda_{\text {probe }}=\right.$ $460 \mathrm{~nm})$ and five cycloarenes $\left(\lambda_{\text {exc }}=365 \mathrm{~nm}, \lambda_{\text {probe }}=553 \mathrm{~nm}, 554 \mathrm{~nm}, 534 \mathrm{~nm}, 561 \mathrm{~nm}\right.$ and $559 \mathrm{~nm}$, respectively). 

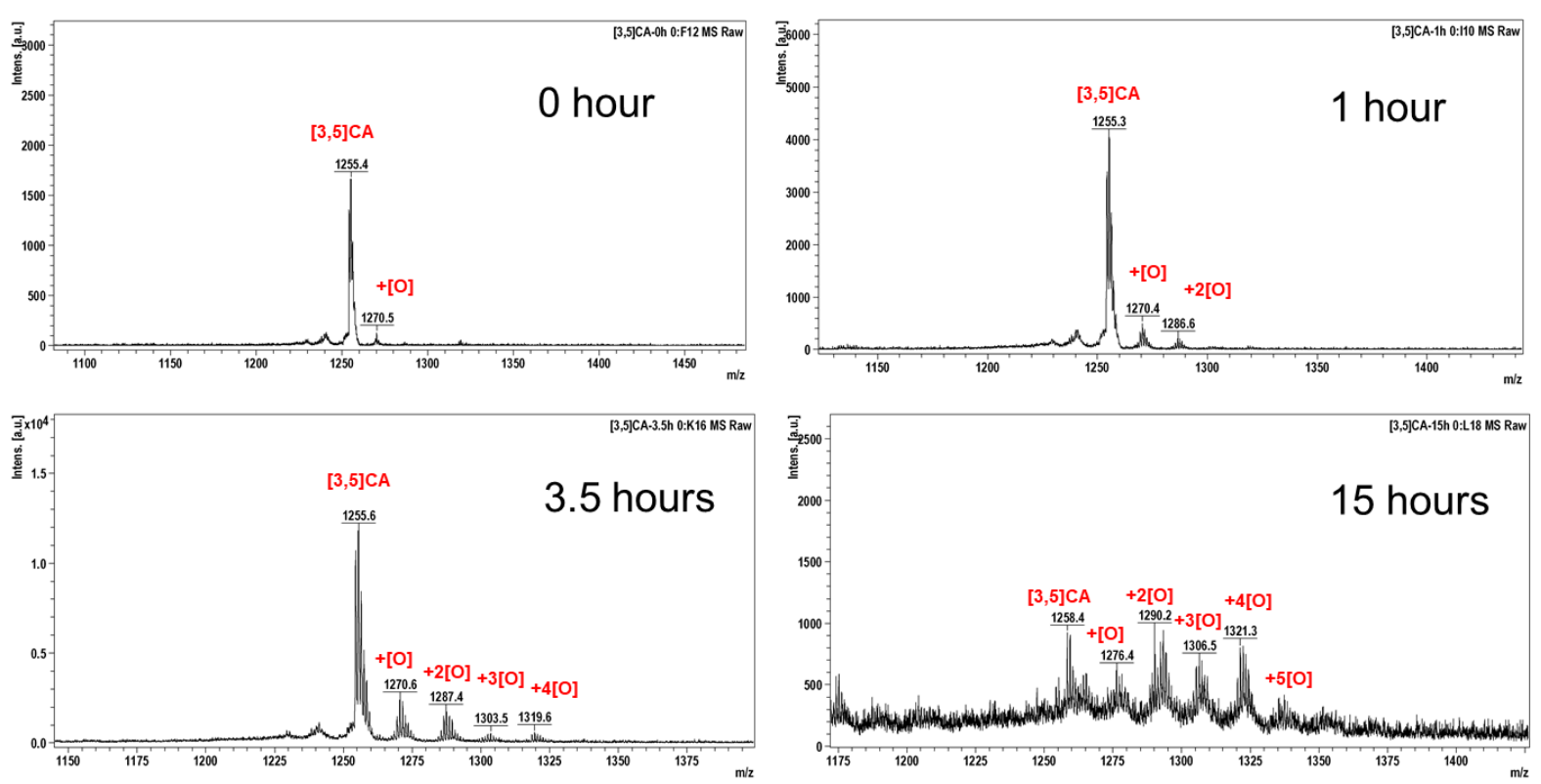

Figure S25. Time-dependent of mass spectra (MALDI-TOF) of [3,5]CA in DCM exposed to air and ambient light.
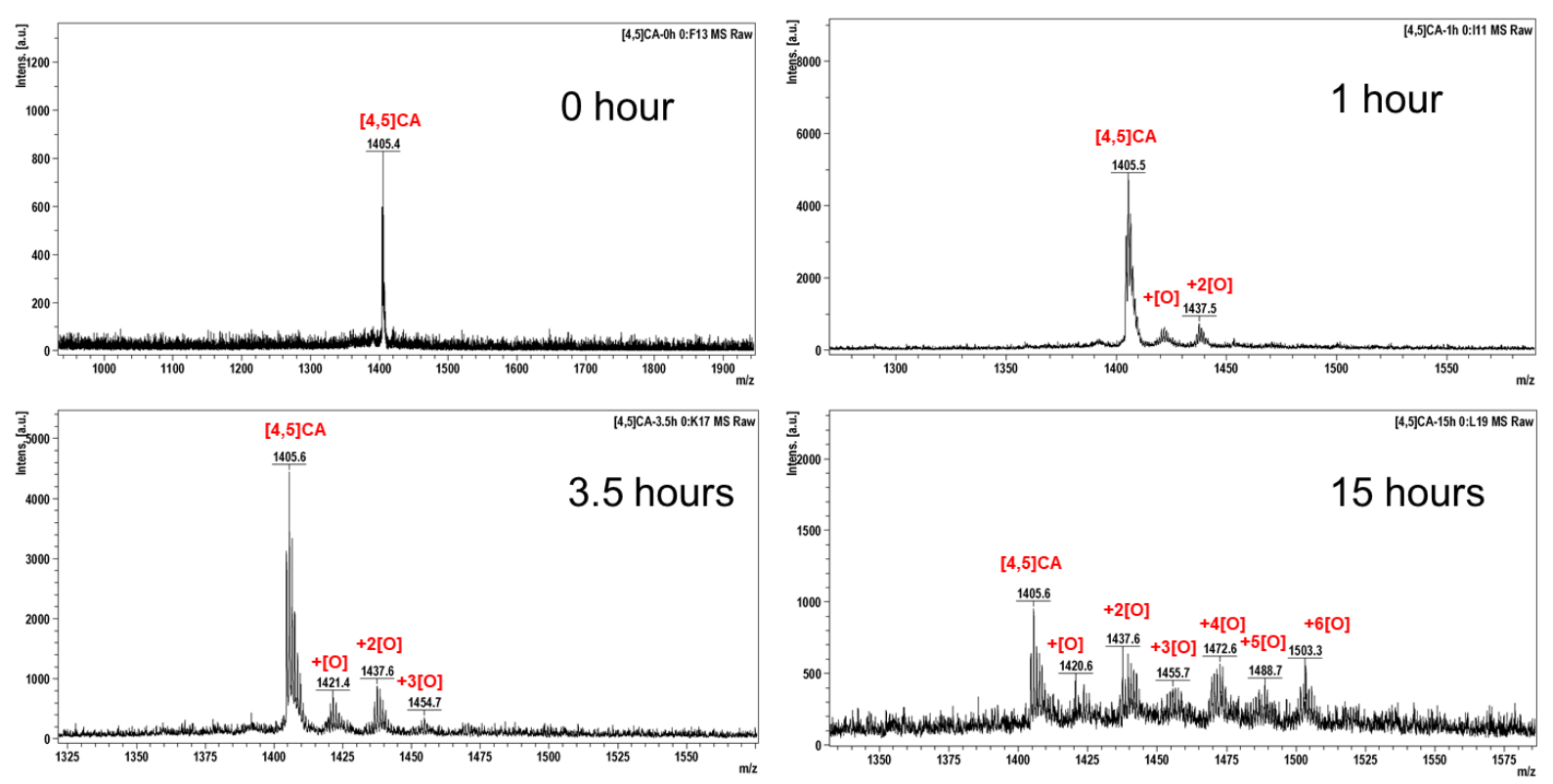

Figure S26. Time-dependent of mass spectra (MALDI-TOF) of [4,5]CA in DCM exposed to air and ambient light. 
(a)

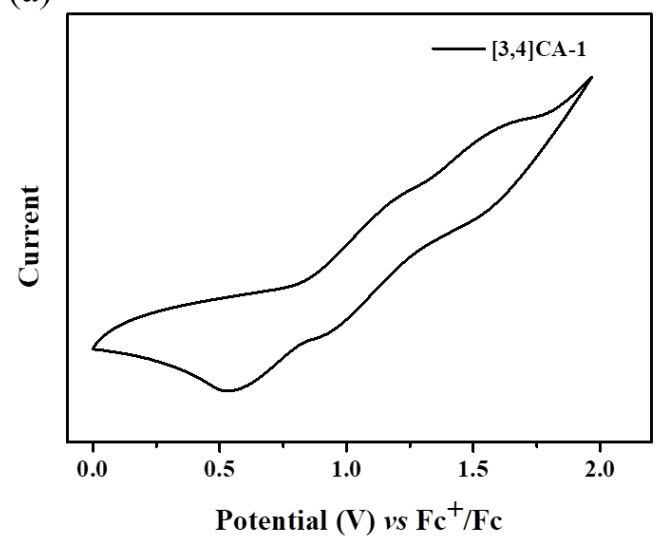

(b)

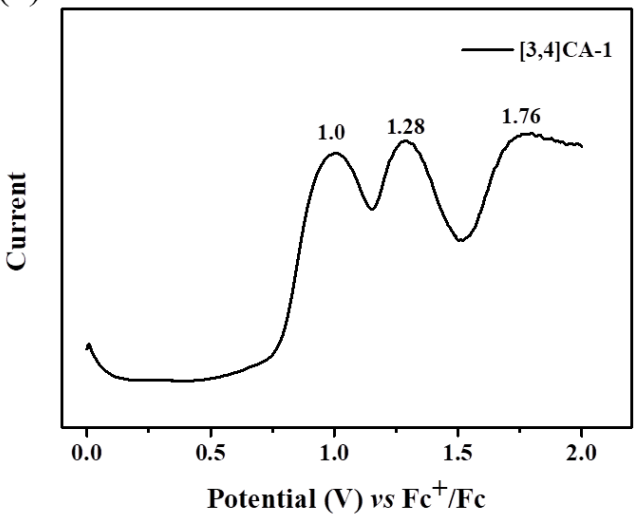

Figure S27. Cyclic voltammogram (a) and differential pulse voltammogram (b) of [3,4]CA-1 measured in chlorobenzene with $\mathrm{TBAPF}_{6}$ as the supporting electrolyte.

(a)

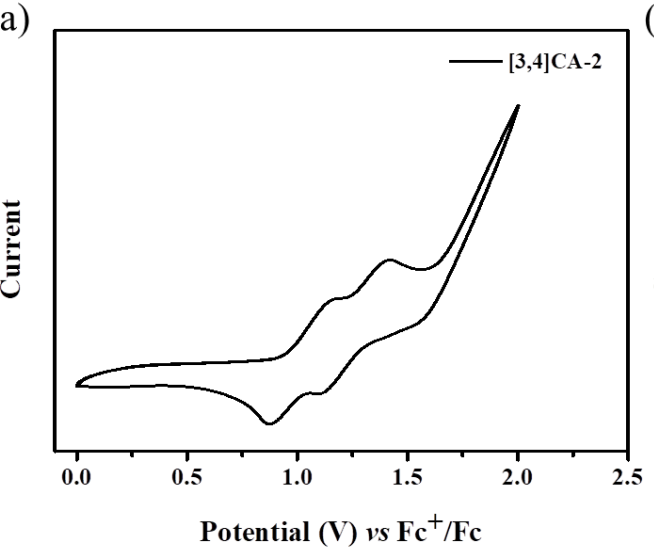

(b)

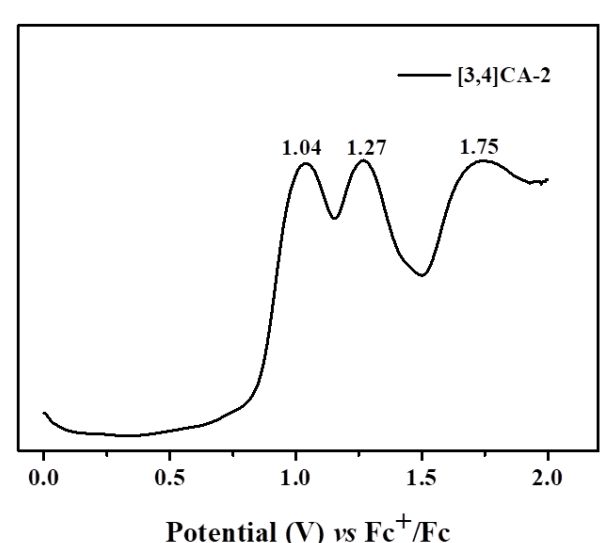

Figure S28. Cyclic voltammogram (a) and differential pulse voltammogram (b) of $[\mathbf{3 , 4}] \mathbf{C A}-2$ measured in chlorobenzene with $\mathrm{TBAPF}_{6}$ as the supporting electrolyte.

(a)

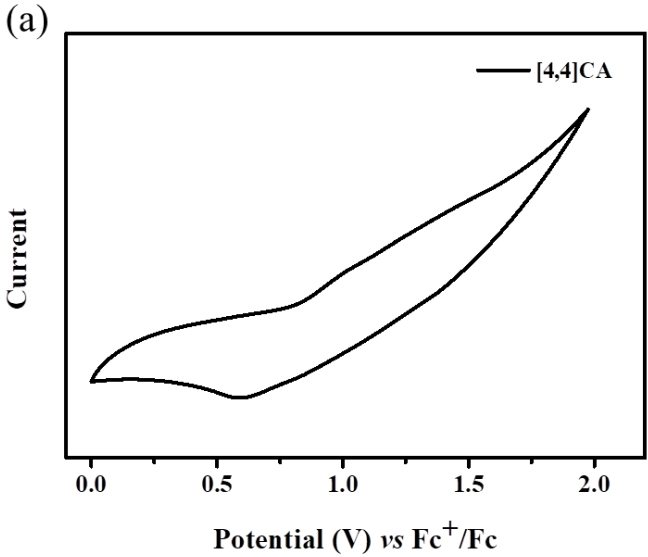

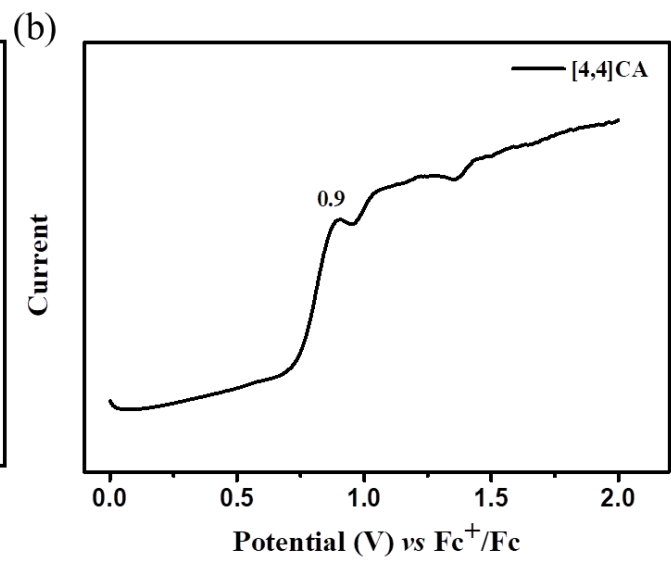

Figure S29. Cyclic voltammogram (a) and differential pulse voltammogram (b) of $[4,4] C A$ measured in chlorobenzene with $\mathrm{TBAPF}_{6}$ as the supporting electrolyte. 
(a)

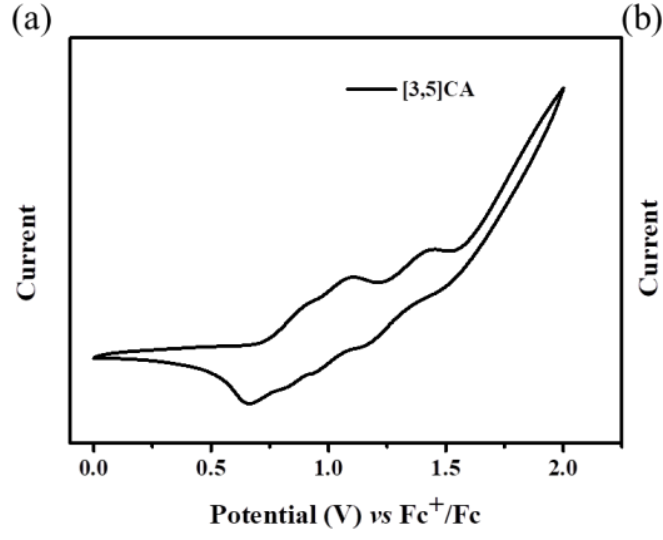

(b)

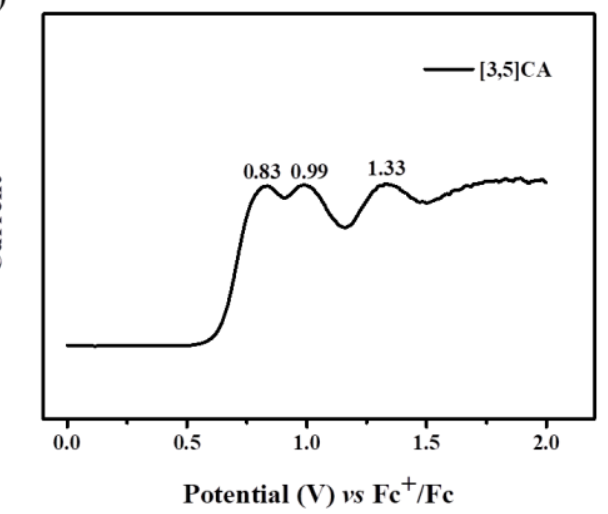

Figure S30. Cyclic voltammogram (a) and differential pulse voltammogram (b) of $[\mathbf{3 , 5}] \mathbf{C A}$ measured in chlorobenzene with $\mathrm{TBAPF}_{6}$ as the supporting electrolyte.

(a)

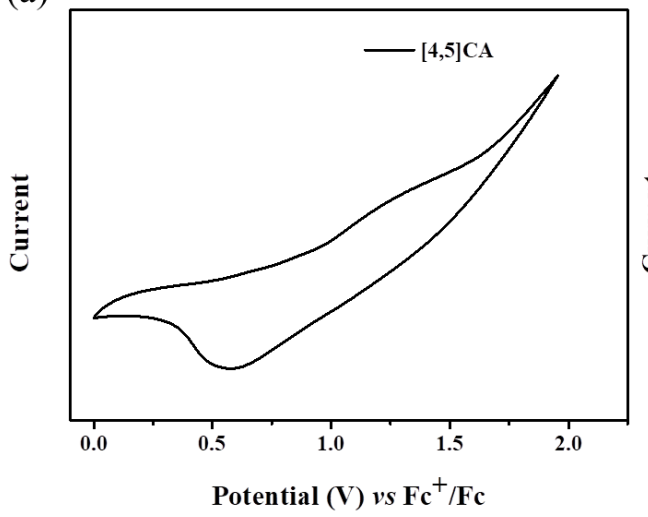

(b)

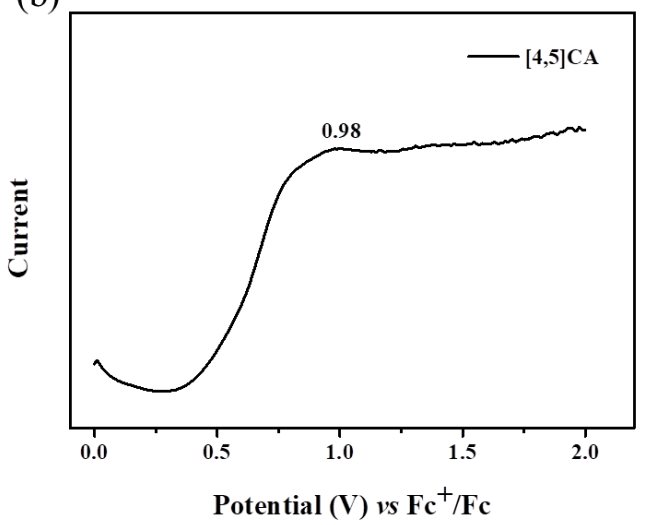

Figure S31. Cyclic voltammogram (a) and differential pulse voltammogram (b) of $[4,5]$ CA measured in chlorobenzene with $\mathrm{TBAPF}_{6}$ as the supporting electrolyte.

\section{DFT calculations}

Density functional theory (DFT) calculations were performed with the Gaussian09 program suite $^{2}$ with Becke's three-parameter hybrid exchange functionals and the Lee-Yang-Parr correlation functional (B3LYP) employing the 6-31G(d,p) basis set for all atoms. ${ }^{3}$ Time-dependent DFT (TD-DFT) calculations were performed at the B3LYP/6-31G(d,p) level of theory under vacuum. NICS values were calculated (B3LYP/6-31G(d,p)) using the standard GIAO procedure (NMR pop=NCSall). ${ }^{4}$ ACID plot (B3LYP/6-31G(d,p)) was calculated by using the method developed by Herges based on the optimized ground-state geometries. ${ }^{5}$ The iso-chemical shielding surface (ICSS) ${ }^{6}$ calculations were carried out and the VMD programme ${ }^{7}$ was used to plot ICSS cube files. 
(a)

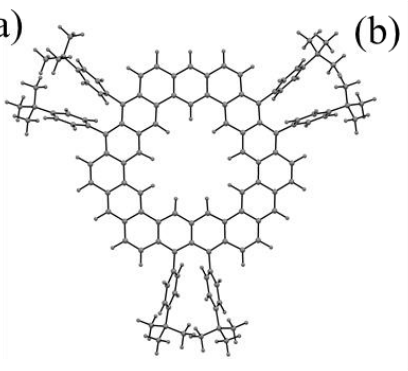

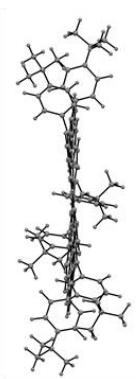

(f)

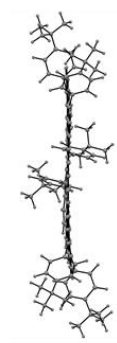

(g)

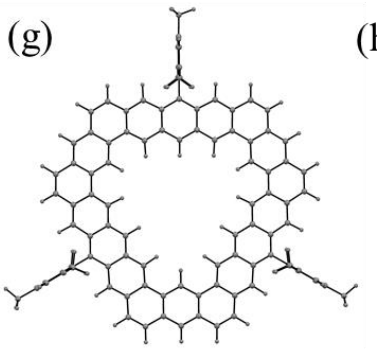

(c)

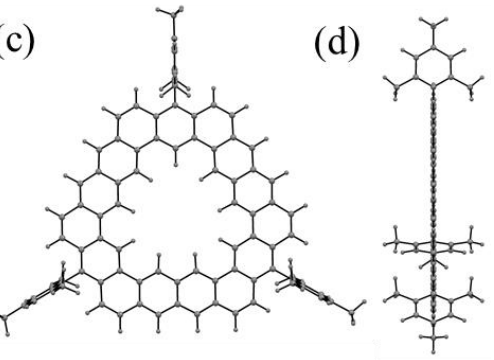

(h)

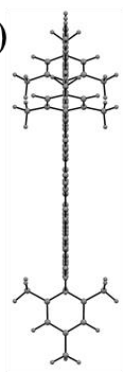

(i)

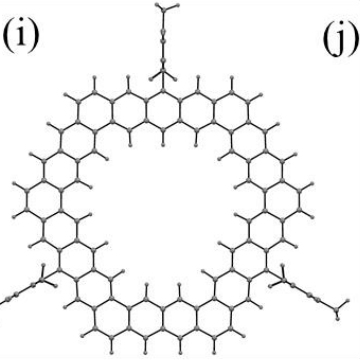

(j)
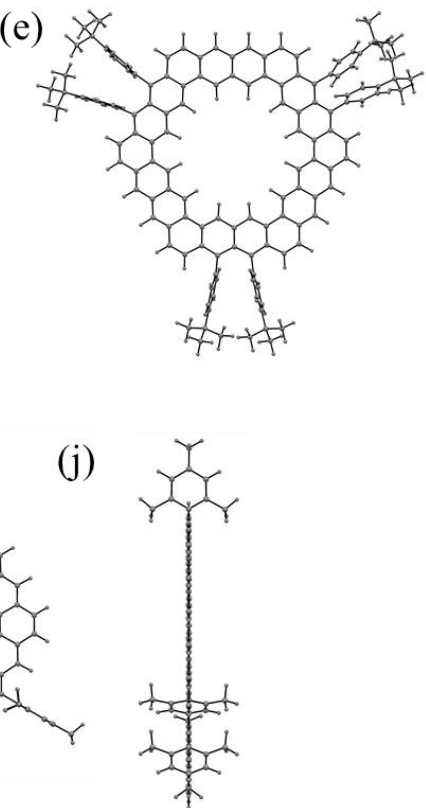

Figure S32. Calculated optimized structures: (a) top-view, (b) side-view for $[\mathbf{3}, \mathbf{4}] \mathbf{C A}-\mathbf{1}$; (c) top-view, (d) side-view for [3,4]CA-2; (e) top-view, (f) side-view for $[\mathbf{4 , 4}] \mathrm{CA}$; (g) top-view, (h) side-view for $[\mathbf{3 , 5}] \mathrm{CA}$; (i) top-view, (j) side-view for $[\mathbf{4 , 5}] \mathrm{CA}$.

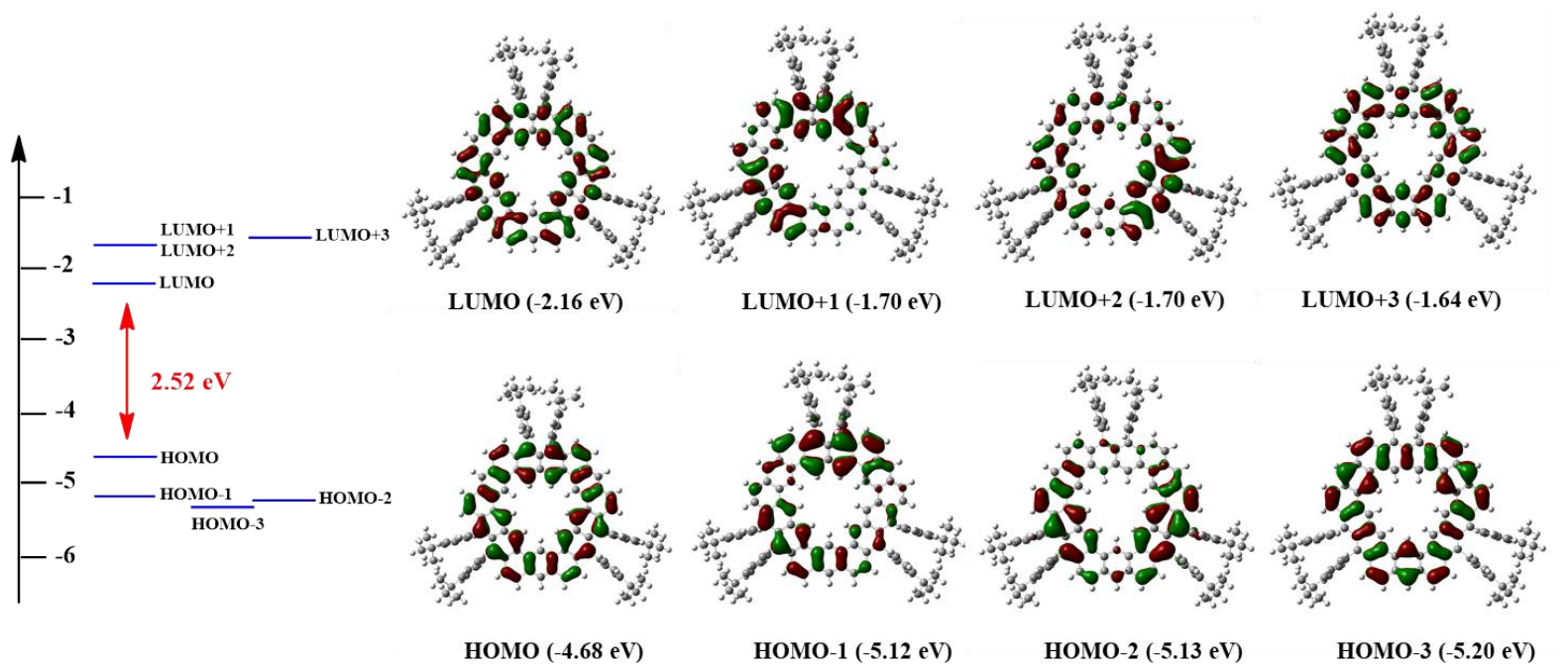

Figure S33. Frontier molecular orbital profiles and energy diagram of $[\mathbf{3 , 4}] \mathrm{CA}-\mathbf{1}$ obtained by B3LYP/6-31G(d,p) level calculation.

Table S1. Selected TD-DFT (B3LYP/6-31G(d,p)) calculated energies, oscillator strength and compositions of major electronic transitions of [3,4]CA-1.

\begin{tabular}{ccc}
\hline Wavelength $(\mathrm{nm})$ & Osc.Strength (f) & Major contributions \\
\hline 567.25165 & 0 & HOMO->LUMO (99\%) \\
495.56015 & 0 & H-3->LUMO (19\%), HOMO->L+3 (76\%) \\
490.89042 & 0 & H-3->LUMO (77\%), HOMO->L+3 (19\%) \\
477.68905 & 0.2442 & H-1->LUMO (70\%), HOMO->L+1 (27\%) \\
\hline
\end{tabular}




\begin{tabular}{|c|c|c|}
\hline 477.358 & 0.2398 & H-2->LUMO (71\%), HOMO->L+2 (26\%) \\
\hline 471.94318 & 0.0058 & H-1->LUMO (27\%), HOMO->L+1 (71\%) \\
\hline 471.63798 & 0.0067 & H-2->LUMO (26\%), HOMO->L+2 (72\%) \\
\hline 432.25671 & 0.0073 & $\begin{array}{l}\text { H-4->LUMO (18\%), H-3->L+1 (20\%), } \\
\text { H-1->L+3 (28\%), HOMO->L+5 (19\%) }\end{array}$ \\
\hline 432.06089 & 0.0079 & $\begin{array}{l}\text { H-5->LUMO (18\%), H-3->L+2 (20\%), } \\
\text { H-2->L+3 (28\%), HOMO->L+4 (19\%) }\end{array}$ \\
\hline 411.55212 & 0 & $\mathrm{H}-2->\mathrm{L}+1(48 \%), \mathrm{H}-1->\mathrm{L}+2(47 \%)$ \\
\hline 404.59533 & 0.0078 & $\mathrm{H}-3->\mathrm{L}+3(10 \%), \mathrm{H}-2->\mathrm{L}+2(22 \%), \mathrm{H}-1->\mathrm{L}+1(63 \%)$ \\
\hline 403.88362 & 0.133 & $\mathrm{H}-2->\mathrm{L}+1(45 \%), \mathrm{H}-1->\mathrm{L}+2(46 \%)$ \\
\hline 403.69951 & 0.1232 & $H-2->L+2(66 \%), H-1->L+1(24 \%)$ \\
\hline 393.7256 & $4 \mathrm{E}-4$ & H-4->LUMO (20\%), H-1->L+3 (18\%), HOMO->L+5 (32\%) \\
\hline 393.61311 & 0 & H-5->LUMO (19\%), H-2->L+3 (19\%), HOMO->L+4 (33\%) \\
\hline 387.54749 & 0.0727 & $\begin{array}{l}\text { H-4->LUMO (19\%), H-3->L+1 (34\%), } \\
\text { H-1->L+3 (22\%), HOMO->L+5 (11\%) }\end{array}$ \\
\hline 387.42639 & 0.0692 & $\begin{array}{l}\text { H-5->LUMO (19\%), H-3->L+2 (34\%), } \\
-2->\mathrm{L}+3(21 \%), \text { HOMO->L+4 (11\%) }\end{array}$ \\
\hline 382.39581 & 0.0016 & $\mathrm{H}-3->\mathrm{L}+3(86 \%)$ \\
\hline 380.05148 & 0.2454 & H-6->LUMO (64\%) \\
\hline 379.33056 & 0.1986 & H-7->LUMO (61\%) \\
\hline 377.73571 & 0.1791 & H-8->LUMO (68\%), H-8->L+1 (11\%) \\
\hline 372.392 & 2.9165 & $\begin{array}{c}\text { H-5->LUMO (23\%), H-3->L+2 (12\%), H-2->L+3 (11\%), } \\
\text { HOMO->L+4 (26\%) }\end{array}$ \\
\hline 372.17961 & 2.8455 & $\begin{array}{l}\text { H-4->LUMO (21\%), H-3->L+1 (11\%), } \\
\text { H-1->L+3 (10\%), HOMO->L+5 (26\%) }\end{array}$ \\
\hline 355.53062 & 0.0059 & $\begin{array}{c}\mathrm{H}-5->\mathrm{L}+2(11 \%), \mathrm{H}-4->\mathrm{L}+1(13 \%), \mathrm{H}-2->\mathrm{L}+5(11 \%), \mathrm{H}-1->\mathrm{L}+4 \\
(12 \%), \mathrm{H}-1->\mathrm{L}+5(10 \%)\end{array}$ \\
\hline 355.41851 & 0.0077 & $\begin{array}{c}\mathrm{H}-5->\mathrm{L}+1(12 \%), \mathrm{H}-4->\mathrm{L}+2(12 \%), \mathrm{H}-2->\mathrm{L}+4(11 \%) \\
\mathrm{H}-1->\mathrm{L}+4(11 \%), \mathrm{H}-1->\mathrm{L}+5(12 \%)\end{array}$ \\
\hline 353.13071 & 0 & $\begin{array}{c}H-5->\mathrm{L}+2(11 \%), \mathrm{H}-2->\mathrm{L}+4(10 \%), \mathrm{H}-2->\mathrm{L}+5(21 \%), \mathrm{H}-1->\mathrm{L}+4 \\
(21 \%)\end{array}$ \\
\hline 351.838 & 0 & $\begin{array}{l}\mathrm{H}-5->\mathrm{L}+1(10 \%), \mathrm{H}-4->\mathrm{L}+2(11 \%), \\
\mathrm{H}-2->\mathrm{L}+4(19 \%), \mathrm{H}-1->\mathrm{L}+5(18 \%)\end{array}$ \\
\hline 347.43091 & 0 & $\begin{array}{l}\mathrm{H}-5->\mathrm{L}+1(16 \%), \mathrm{H}-5->\mathrm{L}+2(13 \%), \mathrm{H}-4->\mathrm{L}+1(13 \%), \\
\mathrm{H}-4->\mathrm{L}+2(15 \%), \mathrm{H}-2->\mathrm{L}+4(13 \%), \mathrm{H}-1->\mathrm{L}+5(14 \%)\end{array}$ \\
\hline 345.07151 & 0 & $\begin{array}{l}\mathrm{H}-5->\mathrm{L}+1(14 \%), \mathrm{H}-5->\mathrm{L}+2(17 \%), \mathrm{H}-4->\mathrm{L}+1(16 \%), \\
\mathrm{H}-4->\mathrm{L}+2(13 \%), \mathrm{H}-2->\mathrm{L}+5(13 \%), \mathrm{H}-1->\mathrm{L}+4(13 \%)\end{array}$ \\
\hline 340.25136 & 0.0263 & H-9->LUMO (38\%), H-5->L+3 (27\%), H-3->L+4 (19\%) \\
\hline 339.99011 & 0.0207 & H-10->LUMO (30\%), H-4->L+3 (33\%), H-3->L+5 (20\%) \\
\hline 336.52949 & 0.0502 & $\begin{array}{l}\text { H-9->LUMO (44\%), H-5->L+3 (22\%), } \\
\text { H-3->L+4 (13\%), HOMO->L+6 (13\%) }\end{array}$ \\
\hline 336.23744 & 0.0511 & H-10->LUMO (49\%), H-4->L+3 (21\%), HOMO->L+7 (13\%) \\
\hline 333.3715 & 0.0208 & $\mathrm{H}-4->\mathrm{L}+3(37 \%), \mathrm{H}-3->\mathrm{L}+5(57 \%)$ \\
\hline 333.31772 & 0.0168 & $H-5->L+3(42 \%), H-3->L+4(54 \%)$ \\
\hline
\end{tabular}




\begin{tabular}{|c|c|c|}
\hline 330.28982 & $3 \mathrm{E}-4$ & $\begin{array}{c}\text { H-7->L+2 (21\%), H-6->LUMO (12\%), } \\
\text { H-6->L+1 (10\%), H-6->L+2 (26\%) }\end{array}$ \\
\hline 329.97337 & $2 \mathrm{E}-4$ & $\begin{array}{c}\text { H-7->LUMO (11\%), H-7->L+1 (16\%), } \\
\text { H-7->L+2 (15\%), H-6->L+2 (25\%) }\end{array}$ \\
\hline 328.75717 & 0.0015 & $\mathrm{H}-8->\mathrm{L}+1(36 \%), \mathrm{H}-6->\mathrm{L}+2(14 \%)$ \\
\hline 328.10467 & 0.003 & H-11->LUMO (83\%) \\
\hline 327.498 & 0.0105 & H-12->LUMO (67\%) \\
\hline 327.47205 & 0.0183 & $\begin{array}{c}\text { H-12->LUMO (10\%), H-7->L+2 (11\%), } \\
\text { H-2->L+4 (11\%), H-1->L+5 (11\%) }\end{array}$ \\
\hline 327.07466 & 0.0098 & H-8->L+1 (39\%), H-2->L+5 (10\%) \\
\hline 324.78701 & 0.0036 & H-13->LUMO (78\%) \\
\hline 322.27962 & 0.029 & $\mathrm{H}-6->\mathrm{L}+3(68 \%)$ \\
\hline 321.93652 & 0.0261 & $H-7->L+3(66 \%)$ \\
\hline 321.00299 & 0.0231 & H-8->L+3 (49\%), HOMO->L+6 (18\%) \\
\hline 319.89317 & 0.0201 & $\mathrm{H}-6->\mathrm{L}+3(12 \%), \mathrm{HOMO}->\mathrm{L}+6(20 \%), \mathrm{HOMO}->\mathrm{L}+7(35 \%)$ \\
\hline 319.52218 & 0.0101 & $\mathrm{H}-8->\mathrm{L}+3(33 \%), \mathrm{HOMO}->\mathrm{L}+6(17 \%), \mathrm{HOMO}->\mathrm{L}+7(18 \%)$ \\
\hline 318.35715 & $7 \mathrm{E}-4$ & $\mathrm{H}-7->\mathrm{L}+2(14 \%), \mathrm{H}-6->\mathrm{L}+1(63 \%)$ \\
\hline 317.65569 & $1 \mathrm{E}-4$ & H-7->L+1 (53\%), H-7->L+2 (18\%), H-6->L+2 (11\%) \\
\hline
\end{tabular}

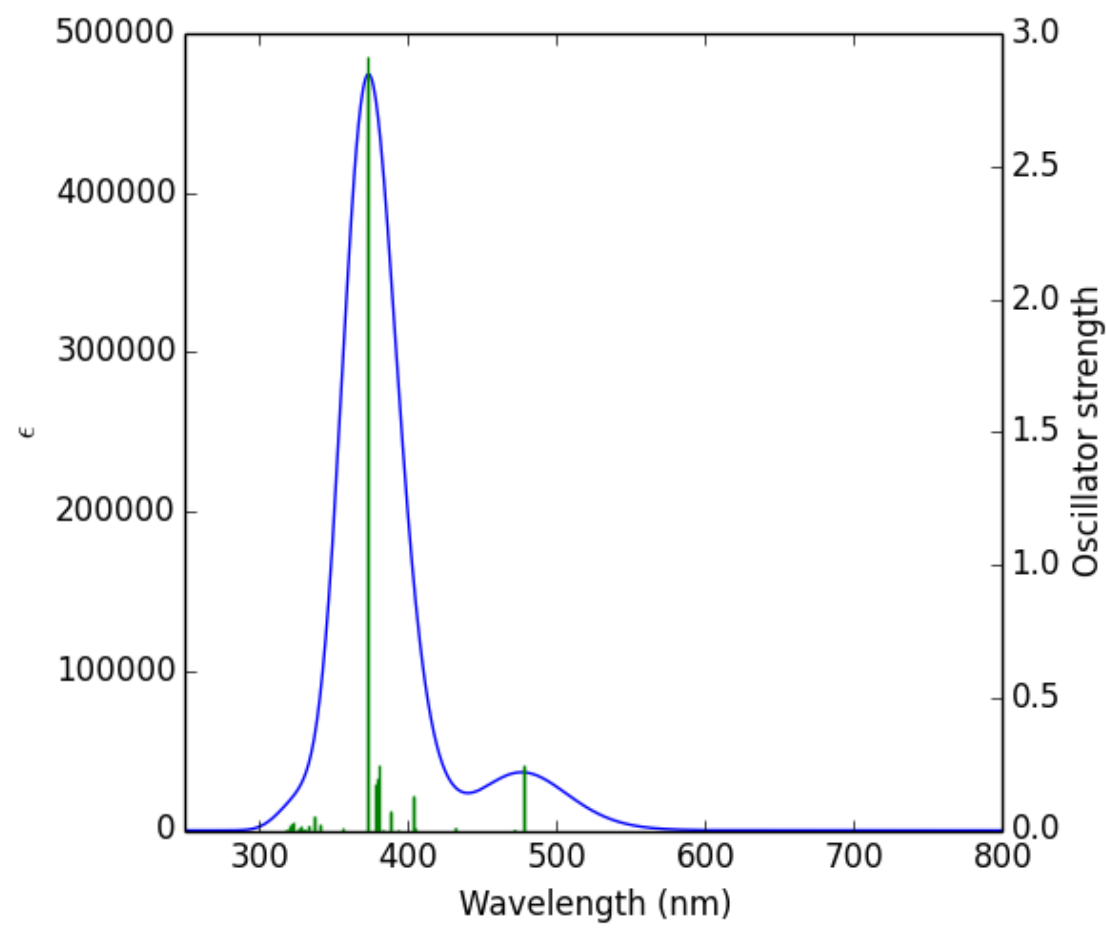

Figure S34. Calculated electronic absorption spectrum (B3LYP/6-31G(d,p)) of [3,4]CA-1. 


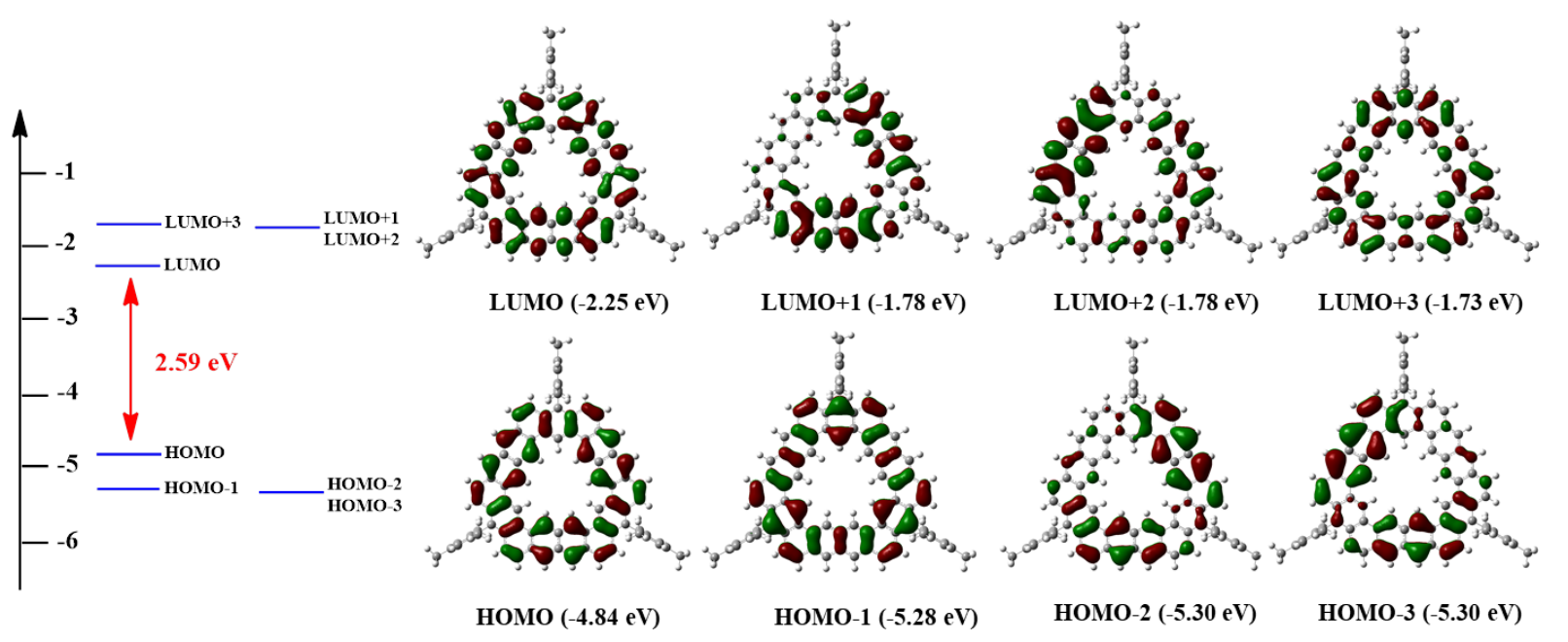

Figure S35. Frontier molecular orbital profiles and energy diagram of [3,4]CA-2 obtained by B3LYP/6-31G(d,p) level calculation.

Table S2. Selected TD-DFT (B3LYP/6-31G(d,p)) calculated energies, oscillator strength and compositions of major electronic transitions of $[\mathbf{3}, \mathbf{4}] \mathbf{C A}-\mathbf{2}$.

\begin{tabular}{|c|c|c|}
\hline Wavelength (nm) & Osc.Strength (f) & Major contributions \\
\hline 554.1193 & 0 & HOMO->LUMO (99\%) \\
\hline 495.48093 & 0 & H-1->LUMO (93\%) \\
\hline 483.78412 & 0 & HOMO->L+3 (93\%) \\
\hline 462.88666 & 0.1094 & H-2->LUMO (52\%), HOMO->L+1 (41\%) \\
\hline 462.8521 & 0.1092 & H-3->LUMO (52\%), HOMO->L+2 (41\%) \\
\hline 459.84791 & $3 \mathrm{E}-4$ & H-2->LUMO (40\%), HOMO->L+1 (54\%) \\
\hline 459.8138 & $3 \mathrm{E}-4$ & H-3->LUMO (40\%), HOMO->L+2 (54\%) \\
\hline 428.80332 & 0.0045 & $\begin{array}{c}\text { H-5->LUMO (11\%), H-4->LUMO (17\%), } \\
\text { H-2->L+3 (22\%), H-1->L+1 (22\%), HOMO->L+5 (17\%) }\end{array}$ \\
\hline 428.78849 & 0.0045 & $\begin{array}{c}\text { H-5->LUMO (17\%), H-4->LUMO (11\%), } \\
\text { H-3->L+3 (22\%), H-1->L+2 (22\%), HOMO->L+4 (17\%) }\end{array}$ \\
\hline 400.49161 & 0 & $\begin{array}{l}\mathrm{H}-3->\mathrm{L}+1(39 \%), \mathrm{H}-3->\mathrm{L}+2(10 \%), \\
\mathrm{H}-2->\mathrm{L}+1(10 \%), \mathrm{H}-2->\mathrm{L}+2(39 \%)\end{array}$ \\
\hline 394.79125 & 0 & $\mathrm{H}-3->\mathrm{L}+2(24 \%), \mathrm{H}-2->\mathrm{L}+1(25 \%), \mathrm{H}-1->\mathrm{L}+3(37 \%)$ \\
\hline 394.18877 & 0.009 & $\begin{array}{l}\text { H-5->LUMO (29\%), H-3->L+2 (12\%), } \\
\text { H-2->L+1 (11\%), H-1->L+1 (25\%) }\end{array}$ \\
\hline 394.18877 & 0.009 & $\begin{array}{c}\text { H-4->LUMO (29\%), H-3->L+1 (11\%), } \\
\text { H-2->L+2 (11\%), H-1->L+2 (25\%) }\end{array}$ \\
\hline 389.67908 & 0.0444 & $\begin{array}{c}\mathrm{H}-3->\mathrm{L}+1(18 \%), \mathrm{H}-3->\mathrm{L}+2(17 \%), \mathrm{H}-2->\mathrm{L}+1(17 \%) \\
\mathrm{H}-2->\mathrm{L}+2(18 \%), \mathrm{H}-1->\mathrm{L}+2(12 \%)\end{array}$ \\
\hline 389.66683 & 0.0441 & $\begin{array}{c}\mathrm{H}-3->\mathrm{L}+1(17 \%), \mathrm{H}-3->\mathrm{L}+2(18 \%), \mathrm{H}-2->\mathrm{L}+1(18 \%), \\
\mathrm{H}-2->\mathrm{L}+2(17 \%), \mathrm{H}-1->\mathrm{L}+1(11 \%)\end{array}$ \\
\hline 382.98642 & 0.0272 & $\begin{array}{c}\text { H-3->L+3 }(11 \%), \mathrm{H}-2->\mathrm{L}+3(32 \%) \\
\text { HOMO->L+4 (25\%), HOMO->L+5 (15\%) }\end{array}$ \\
\hline 382.98642 & 0.027 & $\mathrm{H}-3->\mathrm{L}+3(32 \%), \mathrm{H}-2->\mathrm{L}+3(11 \%)$ \\
\hline
\end{tabular}




\begin{tabular}{|c|c|c|}
\hline & & HOMO->L+4 (15\%), HOMO->L+5 (25\%) \\
\hline 380.27295 & 0 & $\mathrm{H}-3->\mathrm{L}+2(15 \%), \mathrm{H}-2->\mathrm{L}+1(15 \%), \mathrm{H}-1->\mathrm{L}+3(61 \%)$ \\
\hline 369.74888 & 3.2029 & $\begin{array}{l}\text { H-4->LUMO (21\%), H-2->L+3 (16\%), } \\
\text { H-1->L+2 (15\%), HOMO->L+5 (29\%) }\end{array}$ \\
\hline 369.72682 & 3.2038 & $\begin{array}{l}\text { H-5->LUMO (21\%), H-3->L+3 (16\%), } \\
\text { H-1->L+1 (15\%), HOMO->L+4 (29\%) }\end{array}$ \\
\hline 353.04021 & 0.0065 & $\begin{array}{l}\mathrm{H}-5->\mathrm{L}+1(10 \%), \mathrm{H}-5->\mathrm{L}+2(16 \%), \mathrm{H}-4->\mathrm{L}+1(17 \%), \\
\mathrm{H}-4->\mathrm{L}+2(10 \%), \mathrm{H}-3->\mathrm{L}+4(13 \%), \mathrm{H}-2->\mathrm{L}+5(13 \%)\end{array}$ \\
\hline 353.03016 & 0.0064 & $\begin{array}{c}\mathrm{H}-5->\mathrm{L}+1(16 \%), \mathrm{H}-4->\mathrm{L}+1(10 \%), \mathrm{H}-4->\mathrm{L}+2(16 \%) \\
\mathrm{H}-3->\mathrm{L}+5(13 \%), \mathrm{H}-2->\mathrm{L}+4(13 \%)\end{array}$ \\
\hline 351.66835 & 0 & $\mathrm{H}-5->\mathrm{L}+2(33 \%), \mathrm{H}-4->\mathrm{L}+1(32 \%)$ \\
\hline 350.66378 & 0 & $\mathrm{H}-5->\mathrm{L}+1(35 \%), \mathrm{H}-4->\mathrm{L}+2(35 \%)$ \\
\hline 346.92538 & $2 \mathrm{E}-4$ & H-6->LUMO (95\%) \\
\hline 346.67317 & 0 & H-7->LUMO (92\%) \\
\hline 346.66348 & 0 & H-8->LUMO (92\%) \\
\hline 342.962 & 0 & $\mathrm{H}-3->\mathrm{L}+4(37 \%), \mathrm{H}-2->\mathrm{L}+5(37 \%)$ \\
\hline 341.90275 & 0 & $\mathrm{H}-3->\mathrm{L}+5(34 \%), \mathrm{H}-2->\mathrm{L}+4(34 \%)$ \\
\hline 340.29805 & 0.002 & $\mathrm{H}-5->\mathrm{L}+3(23 \%), \mathrm{H}-4->\mathrm{L}+3(27 \%), \mathrm{H}-1->\mathrm{L}+5(30 \%)$ \\
\hline 340.29805 & 0.002 & H-5->L+3 (27\%), H-4->L+3 (24\%), H-1->L+4 (31\%) \\
\hline 335.33712 & 0.0225 & $\mathrm{H}-4->\mathrm{L}+3(38 \%), \mathrm{H}-1->\mathrm{L}+4(20 \%), \mathrm{H}-1->\mathrm{L}+5(35 \%)$ \\
\hline 335.32805 & 0.0224 & $\mathrm{H}-5->\mathrm{L}+3(38 \%), \mathrm{H}-1->\mathrm{L}+4(34 \%), \mathrm{H}-1->\mathrm{L}+5(20 \%)$ \\
\hline 333.91019 & 0.0022 & H-9->LUMO (88\%) \\
\hline 333.9012 & 0.0023 & H-10->LUMO (88\%) \\
\hline 333.73942 & 0 & H-11->LUMO (96\%) \\
\hline 328.21759 & 0.035 & H-12->LUMO (63\%) \\
\hline 328.19152 & 0.0349 & H-13->LUMO (63\%) \\
\hline 324.93171 & 0.0472 & $\begin{array}{c}\text { H-12->LUMO (14\%), H-5->L+2 (11\%), H-4->L+1 (11\%), } \\
\text { H-3->L+4 (19\%), H-2->L+5 (19\%) }\end{array}$ \\
\hline 324.9232 & 0.0474 & $\begin{array}{c}\text { H-13->LUMO (14\%), H-5->L+1 (11\%), } \\
\text { H-4->L+2 (11\%), H-3->L+5 (19\%), H-2->L+4 (19\%) }\end{array}$ \\
\hline 313.06768 & 0 & $\mathrm{H}-8->\mathrm{L}+1(12 \%), \mathrm{H}-7->\mathrm{L}+2(16 \%), \mathrm{H}-6->\mathrm{L}+3(56 \%)$ \\
\hline 312.99655 & $1 \mathrm{E}-4$ & $H-7->L+3(47 \%), H-6->L+2(15 \%)$ \\
\hline 312.98075 & $1 \mathrm{E}-4$ & $\mathrm{H}-8->\mathrm{L}+3(46 \%), \mathrm{H}-6->\mathrm{L}+1(13 \%)$ \\
\hline 312.85439 & 0.0777 & H-12->LUMO (13\%), HOMO->L+6 (75\%) \\
\hline 312.8386 & 0.0773 & H-13->LUMO (13\%), HOMO->L+7 (75\%) \\
\hline 303.16949 & 0 & $\mathrm{H}-5->\mathrm{L}+5(45 \%), \mathrm{H}-4->\mathrm{L}+4(45 \%)$ \\
\hline 302.88065 & 0 & $\begin{array}{l}H-8->L+1(18 \%), H-8->L+3(12 \%), H-7->L+2(13 \%), \\
H-7->L+3(14 \%), H-6->L+1(21 \%), H-6->L+2(15 \%)\end{array}$ \\
\hline 302.87325 & 0 & $\begin{array}{l}\mathrm{H}-8->\mathrm{L}+2(13 \%), \mathrm{H}-8->\mathrm{L}+3(13 \%), \mathrm{H}-7->\mathrm{L}+1(17 \%), \\
\mathrm{H}-7->\mathrm{L}+3(12 \%), \mathrm{H}-6->\mathrm{L}+1(12 \%), \mathrm{H}-6->\mathrm{L}+2(23 \%)\end{array}$ \\
\hline 302.84366 & 0 & $\mathrm{H}-8->\mathrm{L}+1(32 \%), \mathrm{H}-7->\mathrm{L}+2(33 \%), \mathrm{H}-6->\mathrm{L}+3(24 \%)$ \\
\hline 301.62067 & 0.1479 & $\begin{array}{c}\text { H-15->LUMO (30\%), H-14->LUMO (26\%), } \\
\text { HOMO->L+9 (15\%) }\end{array}$ \\
\hline
\end{tabular}




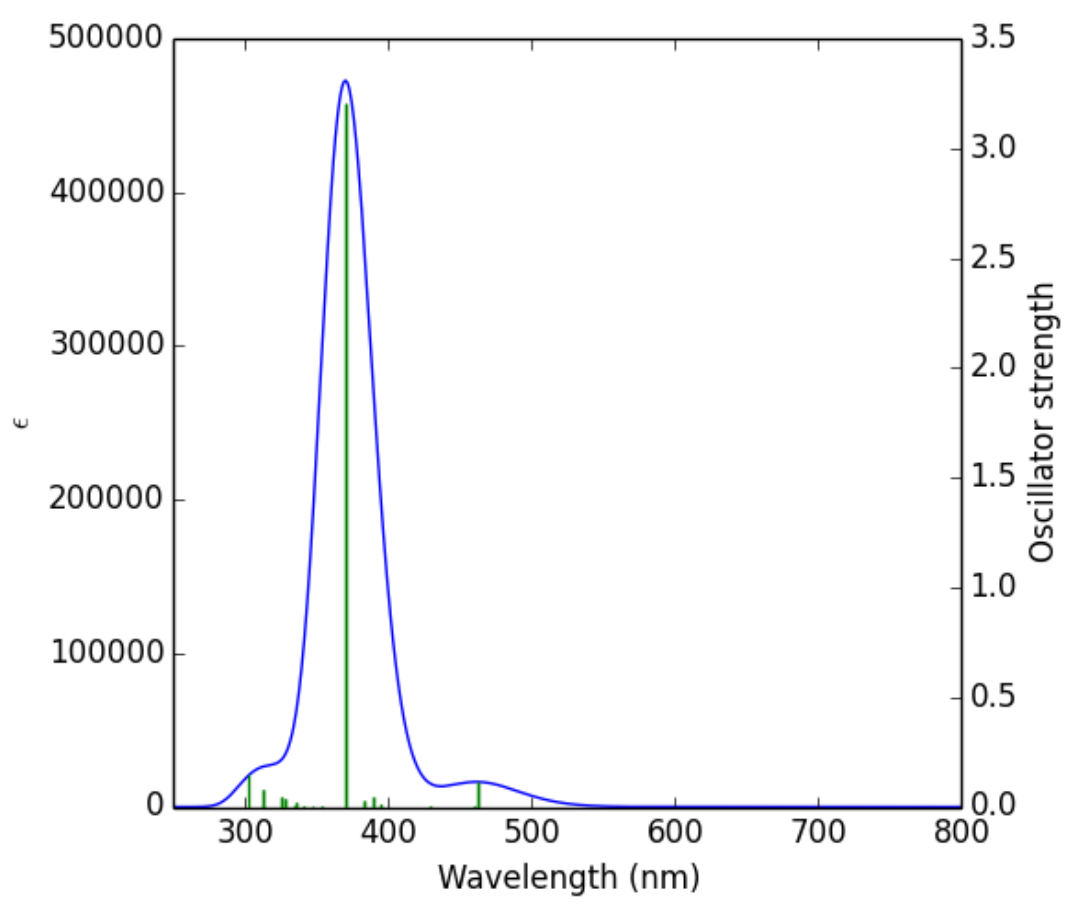

Figure S36. Calculated electronic absorption spectrum (B3LYP/6-31G(d,p)) of [3,4]CA-2.

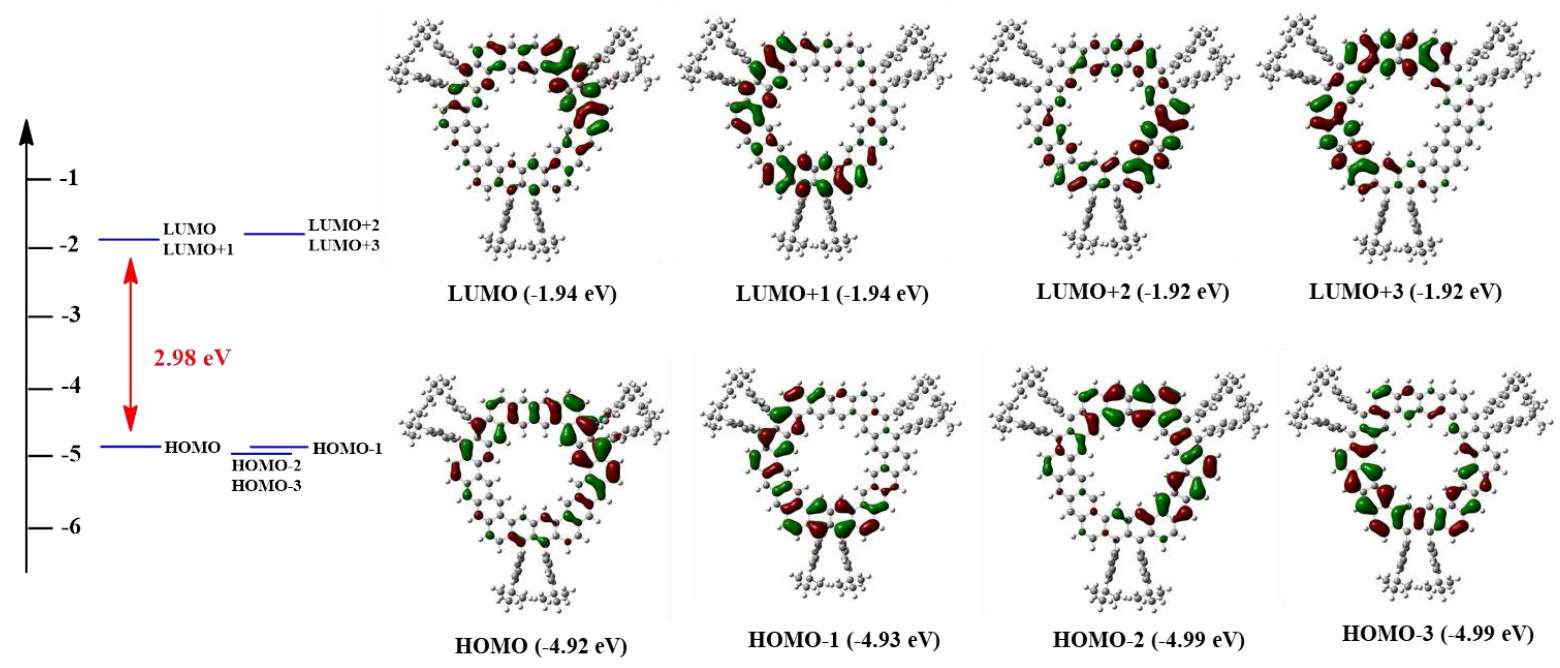

Figure S37. Frontier molecular orbital profiles and energy diagram of $[4,4] C A$ obtained by B3LYP/6-31G(d,p) level calculation.

Table S3. Selected TD-DFT (B3LYP/6-31G(d,p)) calculated energies, oscillator strength and compositions of major electronic transitions of $[4,4] \mathrm{CA}$.

\begin{tabular}{ccc}
\hline Wavelength $(\mathrm{nm})$ & Osc.Strength $(\mathrm{f})$ & \multicolumn{1}{c}{ Major contributions } \\
\hline 511.95059 & $9 \mathrm{E}-4$ & $\mathrm{H}-1->\mathrm{L}+2(33 \%), \mathrm{HOMO}->\mathrm{L}+3(42 \%)$ \\
501.25002 & $6 \mathrm{E}-4$ & $\mathrm{H}-3->\mathrm{L}+1(36 \%), \mathrm{H}-2->\mathrm{LUMO}(43 \%)$ \\
491.3768 & 0.0108 & $\mathrm{H}-3->\mathrm{L}+1(18 \%), \mathrm{H}-2->\mathrm{LUMO}(12 \%)$, \\
& & $\mathrm{H}-1->\mathrm{L}+2(28 \%)$, HOMO->L+3 (22\%) \\
490.4438 & 0.0077 & $\mathrm{H}-3->$ LUMO $(15 \%), \mathrm{H}-2->\mathrm{L}+1(15 \%)$, \\
\hline
\end{tabular}




\begin{tabular}{|c|c|c|}
\hline & & $\mathrm{H}-1->\mathrm{L}+3(23 \%), \mathrm{HOMO}->\mathrm{L}+2(26 \%)$ \\
\hline 479.85213 & 0.009 & $\begin{array}{c}\mathrm{H}-3->\mathrm{L}+2(10 \%), \mathrm{H}-2->\mathrm{L}+3(16 \%) \\
\mathrm{H}-1->\mathrm{L}+1(22 \%), \mathrm{HOMO}->\operatorname{LUMO}(51 \%)\end{array}$ \\
\hline 470.08225 & 0.116 & H-3->L+2 (13\%), H-1->L+1 (33\%), HOMO->LUMO (18\%) \\
\hline 469.37041 & 0.0886 & H-1->LUMO (21\%), HOMO->L+1 (29\%) \\
\hline 460.44562 & 0.0024 & H-1->L+3 (44\%), HOMO->L+2 (44\%) \\
\hline 459.95026 & $2 \mathrm{E}-4$ & H-1->LUMO (47\%), HOMO->L+1 (38\%) \\
\hline 450.22948 & 0.0523 & $\begin{array}{c}\text { H-3->LUMO (23\%), H-3->L+2 (11\%), } \\
\text { H-2->L+3 (37\%), HOMO->LUMO (12\%) }\end{array}$ \\
\hline 448.84405 & 0.1223 & $\mathrm{H}-3->\mathrm{L}+3(11 \%), \mathrm{H}-2->\mathrm{L}+2(67 \%)$ \\
\hline 448.68162 & 0.3334 & H-2->L+1 (35\%), H-2->L+3 (23\%), HOMO->LUMO (11\%) \\
\hline 447.8227 & 0.4765 & $\begin{array}{c}\text { H-3->L+1 (13\%), H-3->L+3 (53\%), } \\
\text { H-1->LUMO (13\%), HOMO->L+1 (11\%) }\end{array}$ \\
\hline 447.04764 & 0.2145 & H-3->LUMO (21\%), H-3->L+2 (45\%), H-1->L+1 (19\%) \\
\hline 439.42652 & 1.9338 & $\begin{array}{l}\text { H-3->LUMO (20\%), H-3->L+2 (10\%), H-2->L+1 (17\%), } \\
\text { H-2->L+3 (20\%), H-1->L+3 (16\%), HOMO->L+2 (13\%) }\end{array}$ \\
\hline 439.42652 & 2.016 & $\begin{array}{l}\mathrm{H}-3->\mathrm{L}+1(17 \%), \mathrm{H}-3->\mathrm{L}+3(17 \%), \mathrm{H}-2->\mathrm{LUMO}(21 \%), \\
\mathrm{H}-2->\mathrm{L}+2(12 \%), \mathrm{H}-1->\mathrm{L}+2(15 \%), \mathrm{HOMO}->\mathrm{L}+3(14 \%)\end{array}$ \\
\hline 428.93684 & 0.0058 & $\begin{array}{l}\text { H-5->LUMO (11\%), H-4->L+2 (34\%), H-3->L+4 (14\%), } \\
\text { HOMO->L+4 (15\%), HOMO->L+5 (14\%) }\end{array}$ \\
\hline 428.32928 & 0.0239 & $\begin{array}{c}\mathrm{H}-5->\mathrm{L}+1(12 \%), \mathrm{H}-4->\mathrm{L}+3(37 \%), \mathrm{H}-2->\mathrm{L}+4(12 \%) \\
\mathrm{H}-1->\mathrm{L}+4(16 \%), \mathrm{H}-1->\mathrm{L}+5(13 \%)\end{array}$ \\
\hline 410.02776 & 0.0308 & H-4->LUMO (52\%), HOMO->L+4 (14\%) \\
\hline 409.5537 & 0.041 & $\mathrm{H}-5->\mathrm{L}+1(10 \%), \mathrm{H}-4->\mathrm{L}+1(58 \%)$ \\
\hline 406.13271 & 0.0463 & H-4->LUMO (21\%), HOMO->L+4 (61\%) \\
\hline 404.10741 & 0.0326 & $\mathrm{H}-4->\mathrm{L}+1(12 \%), \mathrm{H}-4->\mathrm{L}+3(12 \%), \mathrm{H}-1->\mathrm{L}+4(63 \%)$ \\
\hline 402.05005 & 0.1105 & $\begin{array}{l}\text { H-5->LUMO (10\%), H-4->LUMO (15\%), } \\
\text { H-4->L+2 (33\%), HOMO->L+5 (27\%) }\end{array}$ \\
\hline 400.77642 & 0.0789 & $\begin{array}{c}H-5->\mathrm{L}+1(13 \%), \mathrm{H}-4->\mathrm{L}+1(21 \%), \mathrm{H}-4->\mathrm{L}+3(29 \%), \mathrm{H}-1->\mathrm{L}+5 \\
(20 \%)\end{array}$ \\
\hline 395.7995 & 0.0961 & $\mathrm{H}-4->\mathrm{L}+3(14 \%), \mathrm{H}-2->\mathrm{L}+4(50 \%), \mathrm{H}-2->\mathrm{L}+5(17 \%)$ \\
\hline 395.53434 & 0.113 & $\begin{array}{l}\mathrm{H}-5->\mathrm{L}+2(11 \%), \mathrm{H}-4->\mathrm{L}+2(17 \%) \\
\mathrm{H}-3->\mathrm{L}+4(50 \%), \mathrm{H}-3->\mathrm{L}+5(11 \%)\end{array}$ \\
\hline 392.11927 & 0.0927 & $\mathrm{H}-5->\mathrm{L}+2(39 \%), \mathrm{H}-3->\mathrm{L}+5(30 \%), \mathrm{HOMO}->\mathrm{L}+5(20 \%)$ \\
\hline 391.97051 & 0.0373 & $\mathrm{H}-5->\mathrm{L}+3(43 \%), \mathrm{H}-2->\mathrm{L}+5$ (24\%), H-1->L+5 (24\%) \\
\hline 389.78934 & 0.1301 & H-5->LUMO (42\%), H-5->L+2 (23\%), HOMO->L+5 (27\%) \\
\hline 388.71392 & 0.0355 & H-5->L+1 (11\%), H-5->L+3 (39\%), H-1->L+5 (30\%) \\
\hline 387.41428 & 0.485 & $\mathrm{H}-5->\mathrm{L}+1(45 \%), \mathrm{H}-2->\mathrm{L}+5(35 \%)$ \\
\hline 387.24488 & 0.363 & $\begin{array}{l}\text { H-5->LUMO (18\%), H-5->L+2 (19\%), } \\
\text { H-3->L+4 (12\%), H-3->L+5 (46\%) }\end{array}$ \\
\hline 380.6933 & 0.0096 & H-6->LUMO (86\%) \\
\hline 369.04451 & $4 \mathrm{E}-4$ & H-4->L+4 (73\%), H-4->L+5 (20\%) \\
\hline 365.46557 & $1 \mathrm{E}-4$ & H-7->LUMO (12\%), H-7->L+1 (67\%) \\
\hline 364.3058 & $7 \mathrm{E}-4$ & H-8->LUMO (26\%), H-8->L+1 (52\%) \\
\hline
\end{tabular}




\begin{tabular}{|c|c|c|}
\hline 361.50157 & 0.0201 & H-6->L+1 (10\%), H-6->L+3 (87\%) \\
\hline 356.4403 & $3 \mathrm{E}-4$ & $\begin{array}{l}\mathrm{H}-5->\mathrm{L}+4(26 \%), \mathrm{H}-5->\mathrm{L}+5(11 \%), \\
\mathrm{H}-4->\mathrm{L}+4(22 \%), \mathrm{H}-4->\mathrm{L}+5(37 \%)\end{array}$ \\
\hline 351.53873 & $3 \mathrm{E}-4$ & $\mathrm{H}-5->\mathrm{L}+4(68 \%), \mathrm{H}-4->\mathrm{L}+5(26 \%)$ \\
\hline 349.09391 & 0.0488 & $\mathrm{H}-7->\mathrm{L}+2(72 \%), \mathrm{H}-7->\mathrm{L}+3(10 \%)$ \\
\hline 347.81102 & 0.0221 & $\mathrm{H}-8->\mathrm{L}+2(59 \%), \mathrm{H}-8->\mathrm{L}+3(17 \%)$ \\
\hline 346.42133 & 0.0013 & $\mathrm{H}-6->\mathrm{L}+2(80 \%)$ \\
\hline 345.0427 & 0.0186 & $\mathrm{H}-6->\mathrm{L}+1(82 \%)$ \\
\hline 344.55367 & 0 & $\mathrm{H}-5->\mathrm{L}+5(83 \%), \mathrm{H}-4->\mathrm{L}+5(13 \%)$ \\
\hline 340.68143 & 0.0662 & H-9->LUMO (44\%), H-9->L+2 (13\%), HOMO->L+6 (10\%) \\
\hline 340.02741 & 0.0688 & H-9->L+1 (47\%), H-9->L+3 (11\%) \\
\hline 336.3469 & 0.0341 & H-9->LUMO (25\%), H-9->L+2 (52\%) \\
\hline 335.89129 & 0.0239 & H-9->L+1 (19\%), H-9->L+3 (59\%) \\
\hline 334.6673 & 0.0051 & H-7->L+2 (10\%), H-7->L+3 (66\%) \\
\hline 334.19821 & $9 \mathrm{E}-4$ & H-7->LUMO (45\%) \\
\hline
\end{tabular}

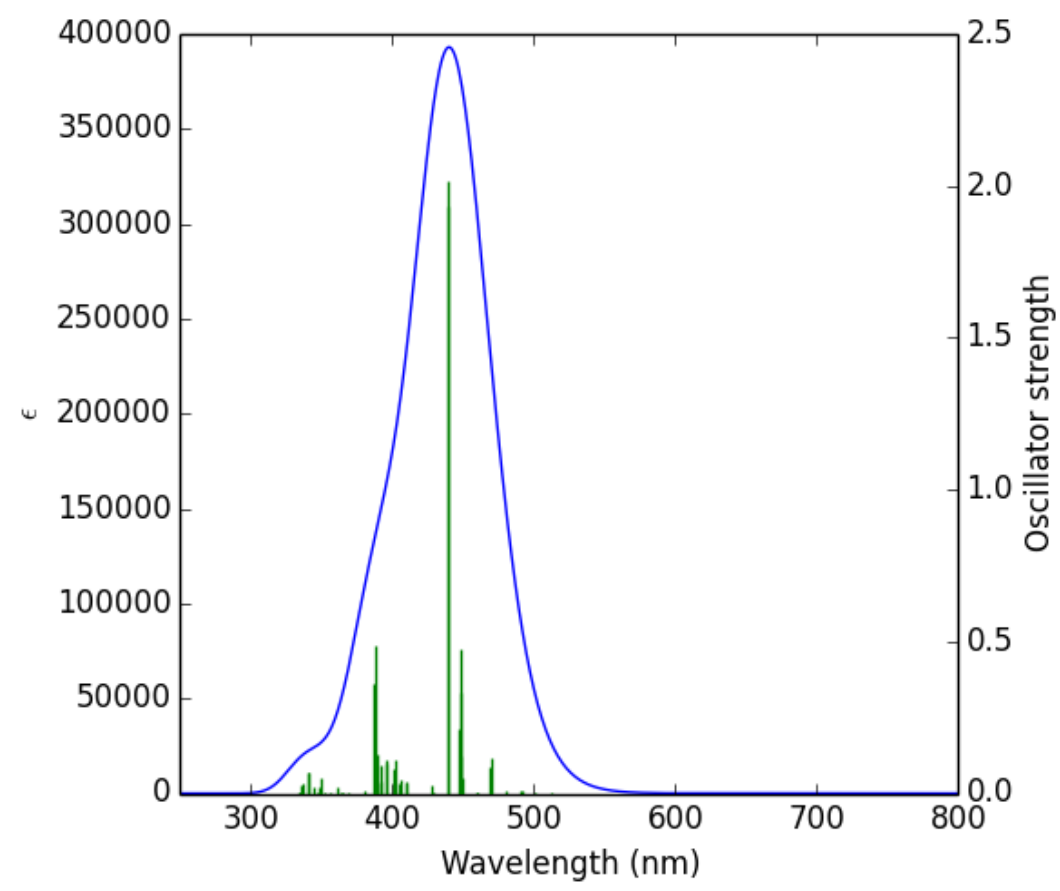

Figure S38. Calculated electronic absorption spectrum (B3LYP/6-31G(d,p)) of $[\mathbf{4 , 4}, \mathbf{C A}$. 

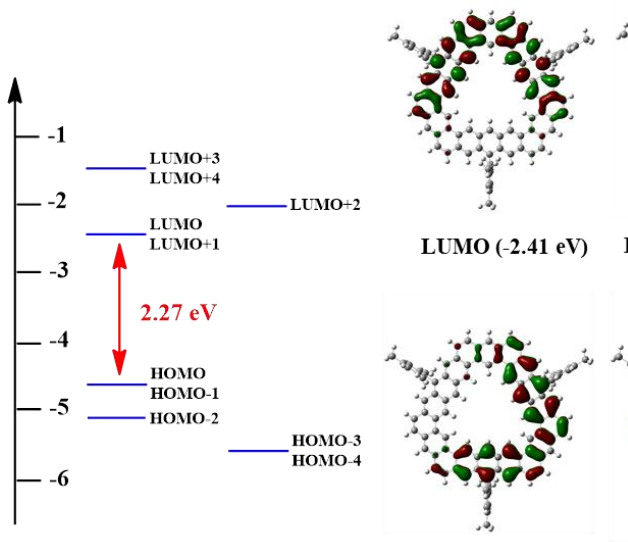

LUMO (-2.41 eV) LUMO+1 (-2.41 eV)
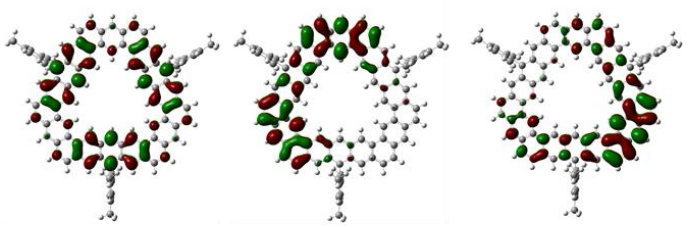

LUMO + $2(-2.01 \mathrm{eV}) \quad$ LUMO $+3(-1.50 \mathrm{eV}) \quad$ LUMO $+4(-1.50 \mathrm{eV})$
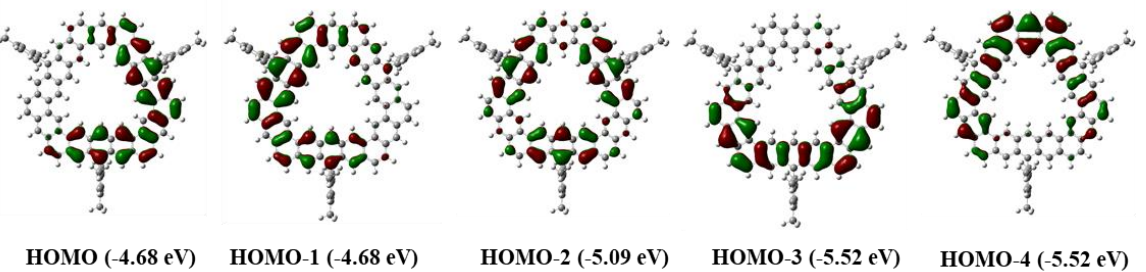

Figure S39. Frontier molecular orbital profiles and energy diagram of $[\mathbf{3 , 5}] \mathbf{C A}$ obtained by B3LYP/6-31G(d,p) level calculation.

Table S4. Selected TD-DFT (B3LYP/6-31G(d,p)) calculated energies, oscillator strength and compositions of major electronic transitions of $[\mathbf{3 , 5}] \mathbf{C A}$.

\begin{tabular}{|c|c|c|}
\hline Wavelength (nm) & Osc.Strength (f) & Major contributions \\
\hline 635.03479 & 0 & H-1->LUMO (50\%), HOMO->L+1 (47\%) \\
\hline 631.05916 & 0.0017 & H-1->L+1 (33\%), HOMO->LUMO (63\%) \\
\hline 630.54566 & 0.0694 & H-1->LUMO (48\%), HOMO->L+1 (52\%) \\
\hline 630.54566 & 0.0678 & H-1->L+1 (65\%), HOMO->LUMO (35\%) \\
\hline 527.68213 & 0.0209 & HOMO->L+2 (98\%) \\
\hline 527.65967 & 0.0198 & $\mathrm{H}-1->\mathrm{L}+2(98 \%)$ \\
\hline 525.93617 & 0.0436 & H-2->LUMO (98\%) \\
\hline 525.82464 & 0.0432 & $\mathrm{H}-2->\mathrm{L}+1(99 \%)$ \\
\hline 490.24987 & 0 & H-4->LUMO (46\%), H-3->L+1 (46\%) \\
\hline 478.11273 & 0 & $\mathrm{H}-1->\mathrm{L}+4(40 \%), \mathrm{HOMO}->\mathrm{L}+3(40 \%)$ \\
\hline 469.01529 & 0.0165 & $\begin{array}{l}\text { H-4->LUMO (22\%), H-3->L+1 }(22 \%), \\
\text { H-1->L+4 (15\%), HOMO->L+3 }(15 \%)\end{array}$ \\
\hline 469.01529 & 0.0164 & $\begin{array}{l}\text { H-4->L+1 (22\%), H-3->LUMO (22\%), } \\
\text { H-1->L+3 (15\%), HOMO->L+4 (15\%) }\end{array}$ \\
\hline 448.25985 & 0 & $\mathrm{H}-2->\mathrm{L}+2(95 \%)$ \\
\hline 439.76942 & 0 & H-4->L+1 (44\%), H-3->LUMO (45\%) \\
\hline 429.59077 & 0 & $\mathrm{H}-1->\mathrm{L}+3(41 \%), \mathrm{HOMO}->\mathrm{L}+4(40 \%)$ \\
\hline 421.35665 & 2.0132 & $\begin{array}{l}\text { H-4->LUMO (16\%), H-3->L+1 (16\%), } \\
\text { H-1->L+4 (20\%), HOMO->L+3 (20\%) }\end{array}$ \\
\hline 421.32801 & 2.0148 & $\begin{array}{l}\text { H-4->L+1 (16\%), H-3->LUMO (16\%), } \\
\text { H-1->L+3 (20\%), HOMO->L+4 (20\%) }\end{array}$ \\
\hline 414.17803 & 0.1254 & H-5->LUMO (87\%) \\
\hline 414.10886 & 0.1227 & $\mathrm{H}-5->\mathrm{L}+1(87 \%)$ \\
\hline 406.33236 & 0.026 & $\begin{array}{c}\text { H-6->LUMO }(21 \%), \mathrm{H}-3->\mathrm{L}+2(34 \%), \\
\text { H-2->L+3 }(23 \%), \mathrm{H}-1->\mathrm{L}+6(14 \%)\end{array}$ \\
\hline 406.30573 & 0.0246 & H-6->L+1 (21\%), H-4->L+2 (34\%), \\
\hline
\end{tabular}




\begin{tabular}{|c|c|c|}
\hline & & H-2->L+4 (23\%), HOMO->L+6 (14\%) \\
\hline 395.95118 & 0.0398 & $\mathrm{H}-1->\mathrm{L}+5(91 \%)$ \\
\hline 395.93854 & 0.0394 & HOMO->L+5 (91\%) \\
\hline 382.73814 & 0.1651 & H-6->LUMO (47\%), H-3->L+2 (30\%) \\
\hline 382.69089 & 0.1634 & H-6->L+1 (47\%), H-4->L+2 (30\%) \\
\hline 381.83053 & 0 & H-7->LUMO (35\%), H-7->L+1 (38\%) \\
\hline 381.79526 & 0 & H-9->LUMO (62\%), H-8->LUMO (17\%) \\
\hline 381.73649 & 0 & H-9->L+1 (15\%), H-8->L+1 (57\%) \\
\hline 374.5746 & 0.4332 & $H-3->L+2(27 \%), H-2->L+3(61 \%)$ \\
\hline 374.56329 & 0.4333 & $\mathrm{H}-4->\mathrm{L}+2(27 \%), \mathrm{H}-2->\mathrm{L}+4(61 \%)$ \\
\hline 373.16537 & 0 & $\mathrm{H}-5->\mathrm{L}+2(74 \%)$ \\
\hline 371.28797 & 0.3325 & H-6->LUMO (24\%), H-1->L+6 (65\%) \\
\hline 371.27686 & 0.3312 & H-6->L+1 (24\%), HOMO->L+6 (64\%) \\
\hline 363.24913 & $6 \mathrm{E}-4$ & H-12->LUMO (40\%), H-10->LUMO (35\%) \\
\hline 363.22785 & $3 \mathrm{E}-4$ & H-12->LUMO (20\%), H-11->LUMO (27\%), H-10->L+1 (35\%) \\
\hline 363.17465 & $3 \mathrm{E}-4$ & $\mathrm{H}-12->\mathrm{L}+1(19 \%), \mathrm{H}-11->\mathrm{L}+1$ (48\%), H-10->L+1 (13\%) \\
\hline 355.25557 & 0 & $\mathrm{H}-5->\mathrm{L}+2(11 \%), \mathrm{H}-2->\mathrm{L}+5(69 \%)$ \\
\hline 349.55649 & 0.0167 & H-14->L+1 (38\%), H-13->LUMO (41\%) \\
\hline 349.55649 & 0.0167 & H-14->LUMO (40\%), H-13->L+1 (39\%) \\
\hline 348.01604 & 0 & H-14->L+1 (30\%), H-13->LUMO (28\%), H-6->L+2 (16\%) \\
\hline 347.83053 & 0 & H-14->LUMO (32\%), H-13->L+1 (33\%), H-5->L+2 (11\%) \\
\hline 347.62573 & 0 & H-8->L+1 (11\%), H-7->LUMO (53\%), H-7->L+1 (30\%) \\
\hline 347.59649 & 0 & H-9->LUMO (11\%), H-8->LUMO (71\%) \\
\hline 347.52829 & 0 & H-9->L+1 (80\%), H-8->L+1 (10\%) \\
\hline 346.96422 & 0 & $\begin{array}{l}H-6->L+2(44 \%), H-4->L+4(13 \%) \\
H-3->L+3(13 \%), H-2->L+6(20 \%)\end{array}$ \\
\hline 340.64399 & 0.091 & H-15->LUMO (50\%), H-1->L+9 (24\%) \\
\hline 340.61591 & 0.0903 & $\mathrm{H}-15->\mathrm{L}+1(50 \%), \mathrm{HOMO}->\mathrm{L}+9(24 \%)$ \\
\hline 339.18092 & 0 & $\begin{array}{c}\text { H-14->L+1 (12\%), H-13->LUMO (12\%), } \\
\text { H-6->L+2 (11\%), H-4->L+4 (17\%), H-3->L+3 (18\%) }\end{array}$ \\
\hline 336.91357 & $1 \mathrm{E}-4$ & H-12->L+1 (11\%), H-11->LUMO (57\%), H-10->L+1 (16\%) \\
\hline 336.8861 & $6 \mathrm{E}-4$ & H-12->LUMO (19\%), H-11->L+1 (17\%), H-10->LUMO (48\%) \\
\hline
\end{tabular}




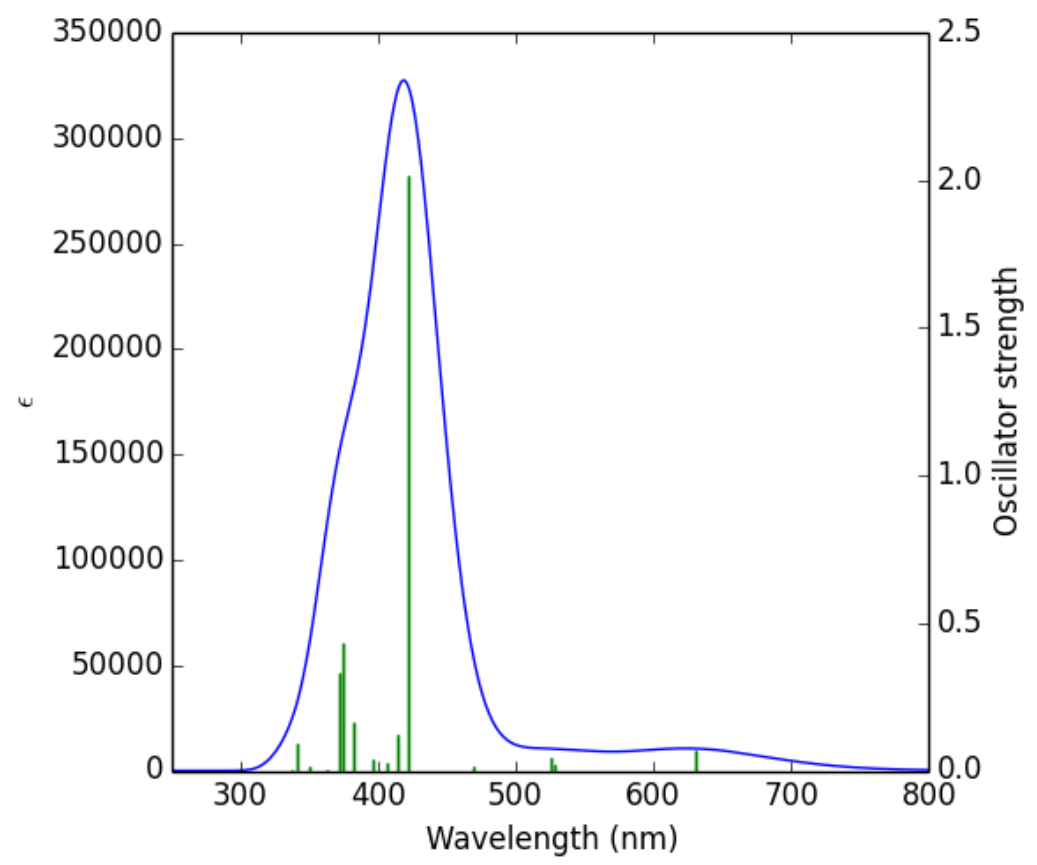

Figure S40. Calculated electronic absorption spectrum (B3LYP/6-31G(d,p)) of [3,5]CA.

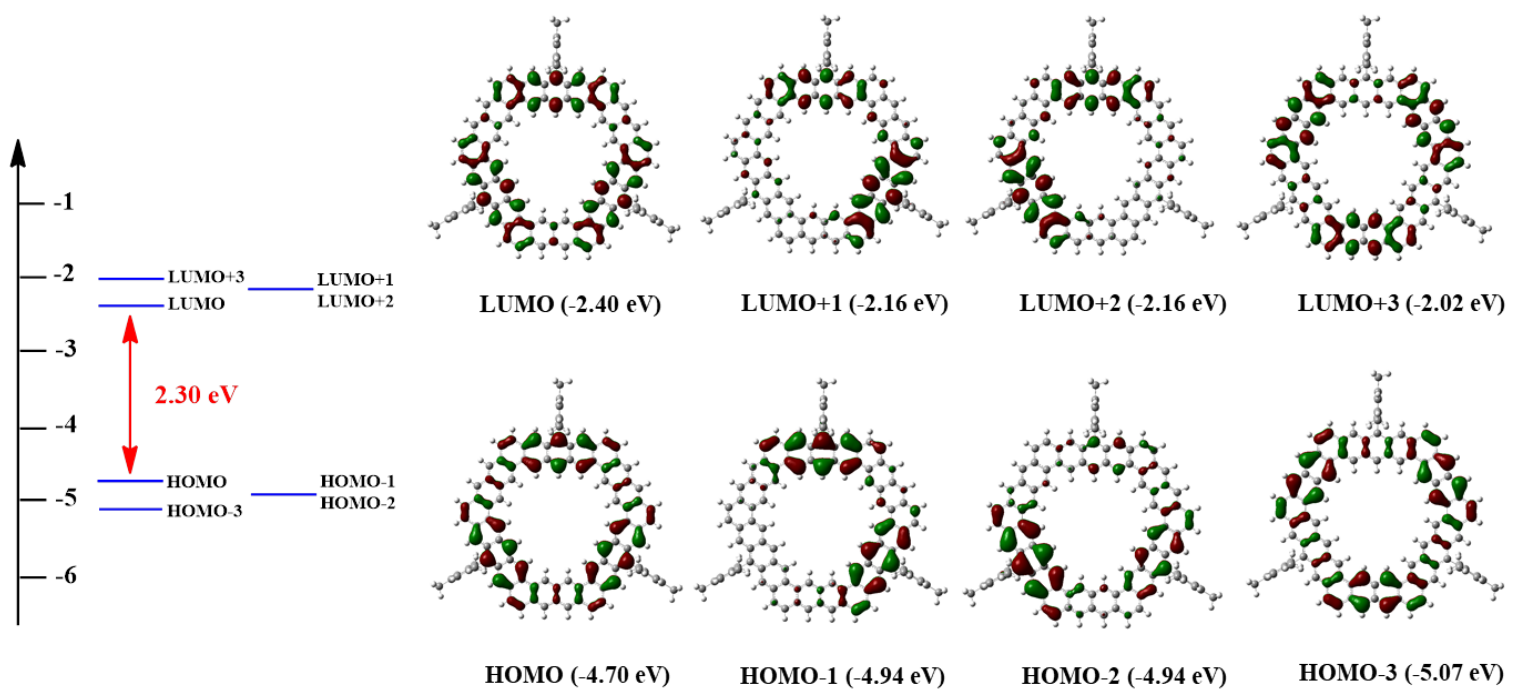

Figure S41. Frontier molecular orbital profiles and energy diagram of $[\mathbf{4 , 5}] \mathbf{C A}$ obtained by B3LYP/6-31G(d,p) level calculation.

Table S5. Selected TD-DFT (B3LYP/6-31G(d,p)) calculated energies, oscillator strength and compositions of major electronic transitions of $[4,5] \mathrm{CA}$.

\begin{tabular}{ccc}
\hline Wavelength $(\mathrm{nm})$ & Osc.Strength (f) & Major contributions \\
\hline 614.05672 & 0 & HOMO->LUMO (98\%) \\
557.93445 & 0.0862 & H-1->LUMO (45\%), HOMO->L+1 (47\%) \\
557.6584 & 0.0867 & H-2->LUMO (45\%), HOMO->L +2 (47\%) \\
556.23236 & $1 \mathrm{E}-4$ & H-3->LUMO (72\%), HOMO->L+3 $(18 \%)$ \\
551.62926 & $1 \mathrm{E}-4$ & H-3->LUMO (19\%), HOMO->L+3 $(73 \%)$ \\
541.22662 & 0.0011 & H-1->LUMO (46\%), HOMO->L+1 (47\%) \\
\hline
\end{tabular}




\begin{tabular}{|c|c|c|}
\hline 541.03767 & $1 \mathrm{E}-3$ & H-2->LUMO (45\%), HOMO->L+2 (47\%) \\
\hline 514.30785 & $5 \mathrm{E}-4$ & $\begin{array}{l}\text { H-4->LUMO (23\%), H-3->L+1 (23\%), } \\
\text { H-1->L+3 (25\%), HOMO->L+4 (15\%) }\end{array}$ \\
\hline 514.22253 & $5 \mathrm{E}-4$ & $\begin{array}{l}\text { H-5->LUMO (23\%), H-3->L+2 (23\%), } \\
\text { H-2->L+3 (25\%), HOMO->L+5 (15\%) }\end{array}$ \\
\hline 497.09002 & $1 \mathrm{E}-4$ & H-2->L+2 (37\%), H-1->L+1 (44\%) \\
\hline 494.01997 & $6 \mathrm{E}-4$ & $\mathrm{H}-2->\mathrm{L}+1(43 \%), \mathrm{H}-1->\mathrm{L}+1(13 \%), \mathrm{H}-1->\mathrm{L}+2(38 \%)$ \\
\hline 493.29272 & 0.0494 & $\mathrm{H}-2->\mathrm{L}+2(47 \%), \mathrm{H}-1->\mathrm{L}+1(33 \%), \mathrm{H}-1->\mathrm{L}+2(11 \%)$ \\
\hline 493.19461 & 0.0452 & $\mathrm{H}-2->\mathrm{L}+1(41 \%), \mathrm{H}-1->\mathrm{L}+2(40 \%)$ \\
\hline 477.76268 & 0 & $\begin{array}{c}\text { H-5->LUMO (22\%), H-3->L+2 (18\%), H-2->L+3 (13\%), } \\
\text { HOMO->L+5 (15\%) }\end{array}$ \\
\hline 477.68905 & $1 \mathrm{E}-4$ & $\begin{array}{l}\text { H-4->LUMO (22\%), H-3->L+1 (18\%), } \\
\text { H-1->L+3 (13\%), HOMO->L+4 (15\%) }\end{array}$ \\
\hline 459.79675 & 2.9472 & H-4->LUMO (37\%), HOMO->L+4 (42\%) \\
\hline 459.7456 & 2.8835 & H-5->LUMO (38\%), HOMO->L+5 (43\%) \\
\hline 458.48751 & 0.3844 & $\mathrm{H}-3->\mathrm{L}+1(39 \%), \mathrm{H}-1->\mathrm{L}+3(39 \%)$ \\
\hline 458.38581 & 0.4605 & $\mathrm{H}-3->\mathrm{L}+2(40 \%), \mathrm{H}-2->\mathrm{L}+3(40 \%)$ \\
\hline 450.99921 & $1 \mathrm{E}-4$ & H-5->L+1 (18\%), H-4->L+2 (17\%), H-3->L+3 (35\%) \\
\hline 445.97026 & $1 \mathrm{E}-4$ & H-5->L+1 (10\%), H-3->L+3 (60\%) \\
\hline 436.22614 & 0.0012 & H-5->L+1 (11\%), H-4->L+1 (10\%), H-4->L+2 (10\%) \\
\hline 436.07271 & 0.0013 & $\mathrm{H}-5->\mathrm{L}+2(10 \%), \mathrm{H}-4->\mathrm{L}+1(12 \%), \mathrm{H}-1->\mathrm{L}+4(10 \%)$ \\
\hline 433.14768 & 0 & $\mathrm{H}-5->\mathrm{L}+2(41 \%), \mathrm{H}-4->\mathrm{L}+1(38 \%)$ \\
\hline 430.02287 & 0 & $\begin{array}{l}\mathrm{H}-2->\mathrm{L}+4(17 \%), \mathrm{H}-2->\mathrm{L}+5(24 \%) \\
\mathrm{H}-1->\mathrm{L}+4(24 \%), \mathrm{H}-1->\mathrm{L}+5(17 \%)\end{array}$ \\
\hline 428.86265 & 0 & $\begin{array}{l}\mathrm{H}-5->\mathrm{L}+1(21 \%), \mathrm{H}-4->\mathrm{L}+2(21 \%), \mathrm{H}-2->\mathrm{L}+4(16 \%), \\
\mathrm{H}-2->\mathrm{L}+5(11 \%), \mathrm{H}-1->\mathrm{L}+4(11 \%), \mathrm{H}-1->\mathrm{L}+5(16 \%)\end{array}$ \\
\hline 418.85137 & 0.0908 & $\mathrm{H}-4->\mathrm{L}+3(46 \%), \mathrm{H}-3->\mathrm{L}+4(41 \%)$ \\
\hline 418.82307 & 0.0898 & $\mathrm{H}-5->\mathrm{L}+3(45 \%), \mathrm{H}-3->\mathrm{L}+5(41 \%)$ \\
\hline 414.17803 & 0.0183 & $\begin{array}{l}\mathrm{H}-5->\mathrm{L}+2(15 \%), \mathrm{H}-4->\mathrm{L}+1(14 \%) \\
\mathrm{H}-2->\mathrm{L}+5(17 \%), \mathrm{H}-1->\mathrm{L}+4(17 \%)\end{array}$ \\
\hline 414.16419 & 0.0195 & $\begin{array}{l}\mathrm{H}-5->\mathrm{L}+1(14 \%), \mathrm{H}-4->\mathrm{L}+2(14 \%), \\
\mathrm{H}-2->\mathrm{L}+4(17 \%), \mathrm{H}-1->\mathrm{L}+5(17 \%)\end{array}$ \\
\hline 403.81785 & 0.0083 & $\mathrm{H}-4->\mathrm{L}+3(47 \%), \mathrm{H}-3->\mathrm{L}+4(48 \%)$ \\
\hline 403.77839 & 0.0083 & $\mathrm{H}-5->\mathrm{L}+3(47 \%), \mathrm{H}-3->\mathrm{L}+5(48 \%)$ \\
\hline 387.71716 & $5 \mathrm{E}-4$ & H-6->LUMO (78\%) \\
\hline 387.58384 & $5 \mathrm{E}-4$ & H-7->LUMO (78\%) \\
\hline 380.93893 & 0 & $\mathrm{H}-5->\mathrm{L}+5(40 \%), \mathrm{H}-4->\mathrm{L}+4(40 \%)$ \\
\hline 377.00062 & 0 & $\mathrm{H}-5->\mathrm{L}+4(39 \%), \mathrm{H}-4->\mathrm{L}+5(44 \%)$ \\
\hline 376.76004 & 0.0013 & $\begin{array}{l}\mathrm{H}-5->\mathrm{L}+4(32 \%), \mathrm{H}-5->\mathrm{L}+5(11 \%), \\
\mathrm{H}-4->\mathrm{L}+4(12 \%), \mathrm{H}-4->\mathrm{L}+5(30 \%)\end{array}$ \\
\hline 376.7028 & 0.0012 & $\begin{array}{l}\mathrm{H}-5->\mathrm{L}+4(14 \%), \mathrm{H}-5->\mathrm{L}+5(32 \%) \\
\mathrm{H}-4->\mathrm{L}+4(29 \%), \mathrm{H}-4->\mathrm{L}+5(10 \%)\end{array}$ \\
\hline 373.9194 & 0 & H-9->LUMO (61\%), H-9->L+1 (35\%) \\
\hline 373.86302 & 0 & H-8->LUMO (61\%), H-8->L+2 (33\%) \\
\hline
\end{tabular}




\begin{tabular}{|c|c|c|}
\hline 373.67147 & 0 & H-10->LUMO (61\%), H-10->L+1 (17\%), H-10->L+2 (20\%) \\
\hline 367.51302 & 0.0012 & HOMO->L+6 (70\%) \\
\hline 367.415 & 0.0013 & HOMO->L+7 (70\%) \\
\hline 366.9257 & 0 & H-7->L+2 (40\%), H-6->L+1 (40\%) \\
\hline 357.74647 & 0.0321 & $\begin{array}{l}H-7->L+1(15 \%), H-7->L+2(22 \%), \\
H-6->L+1(22 \%), H-6->L+2(15 \%)\end{array}$ \\
\hline 357.67422 & 0.0314 & $\begin{array}{c}H-7->L+1(22 \%), H-7->L+2(15 \%), \\
H-6->L+1(15 \%), H-6->L+2(22 \%)\end{array}$ \\
\hline 356.01043 & 0.0056 & H-13->L+1 (17\%), H-12->LUMO (35\%), H-11->LUMO (21\%) \\
\hline 355.97977 & 0.0056 & H-12->LUMO (21\%), H-12->L+2 (11\%), H-11->LUMO (42\%) \\
\hline 355.87759 & $1 \mathrm{E}-4$ & H-13->LUMO (57\%), H-12->L+1 (15\%), H-11->L+2 (14\%) \\
\hline 352.5784 & 0.1308 & H-15->LUMO (22\%), H-7->L+3 (25\%) \\
\hline
\end{tabular}

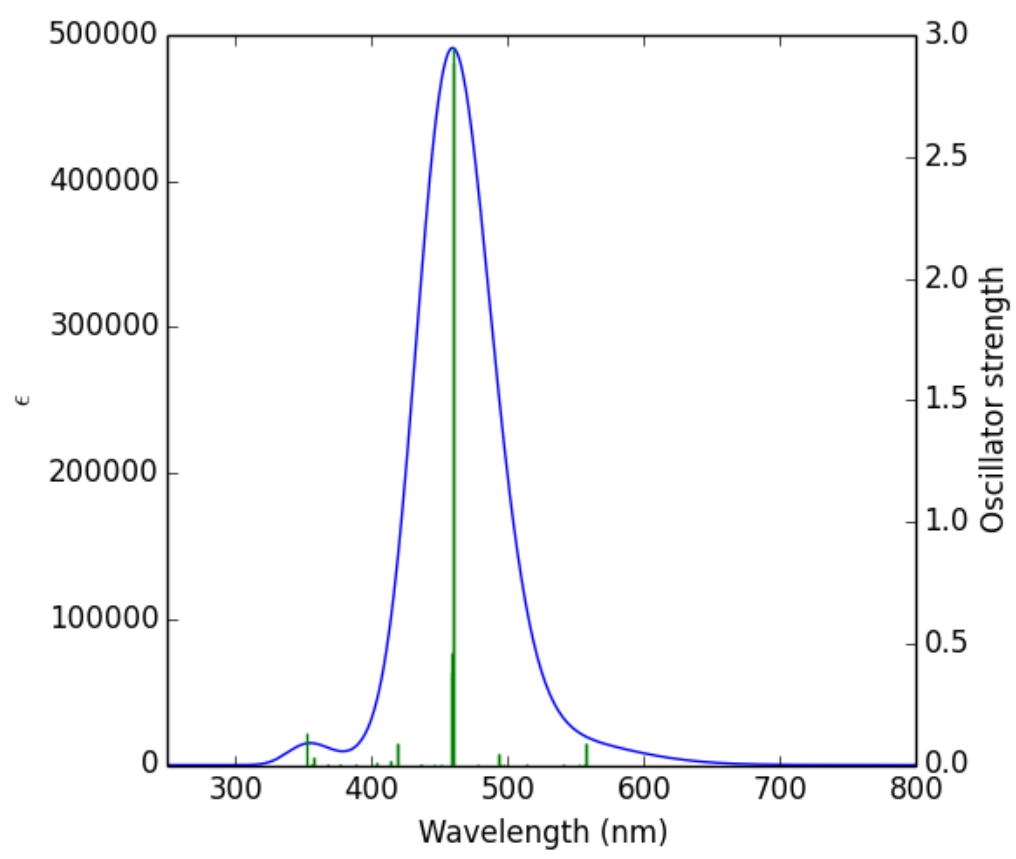

Figure S42. Calculated electronic absorption spectrum (B3LYP/6-31G(d,p)) of [4,5]CA.

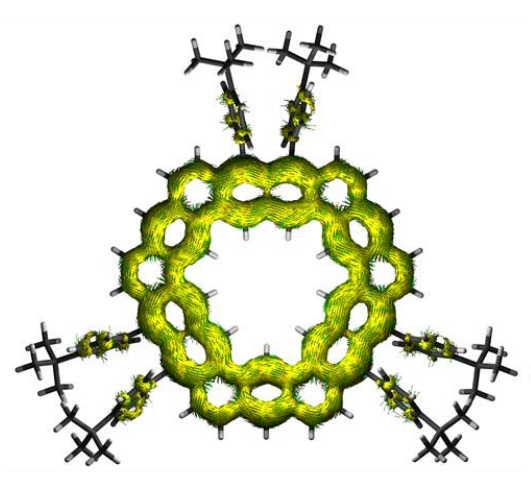

isovalue: 0.02

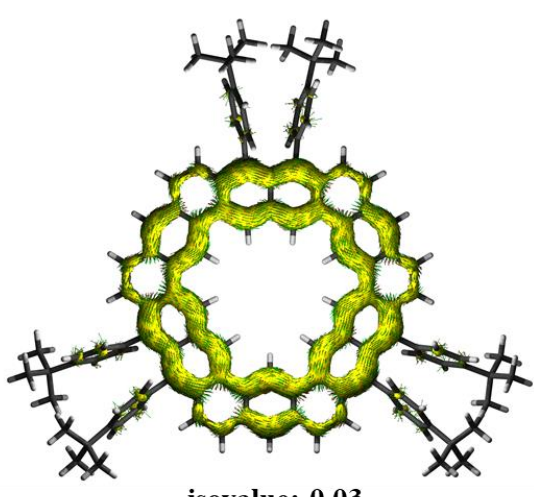

isovalue: 0.03

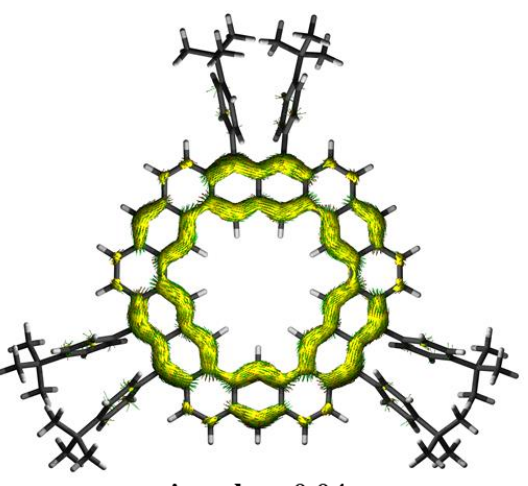

isovalue: 0.04

Figure S43. Calculated ACID plots of $[3,4]$ CA-1 with different isovalues. 


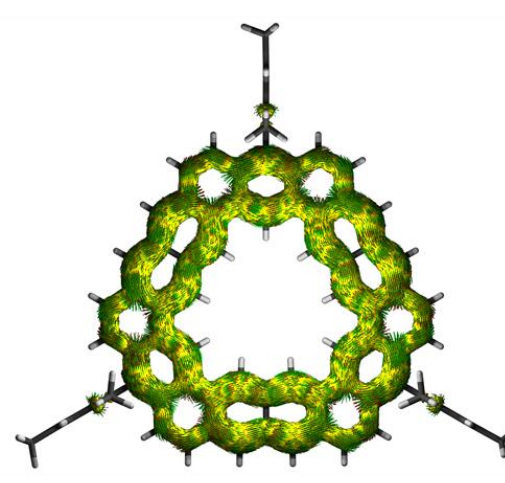

isovalue: $\mathbf{0 . 0 2}$

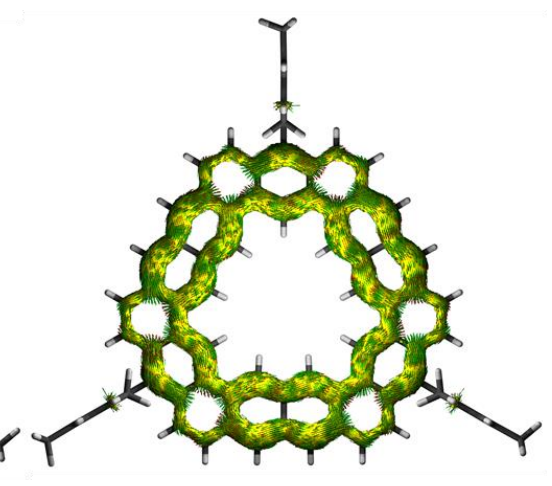

isovalue: $\mathbf{0 . 0 3}$

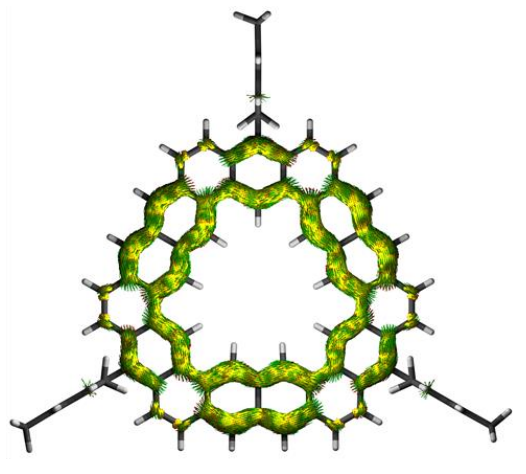

isovalue: 0.04

Figure S44. Calculated ACID plots of $[3,4]$ CA-2 with different isovalues.

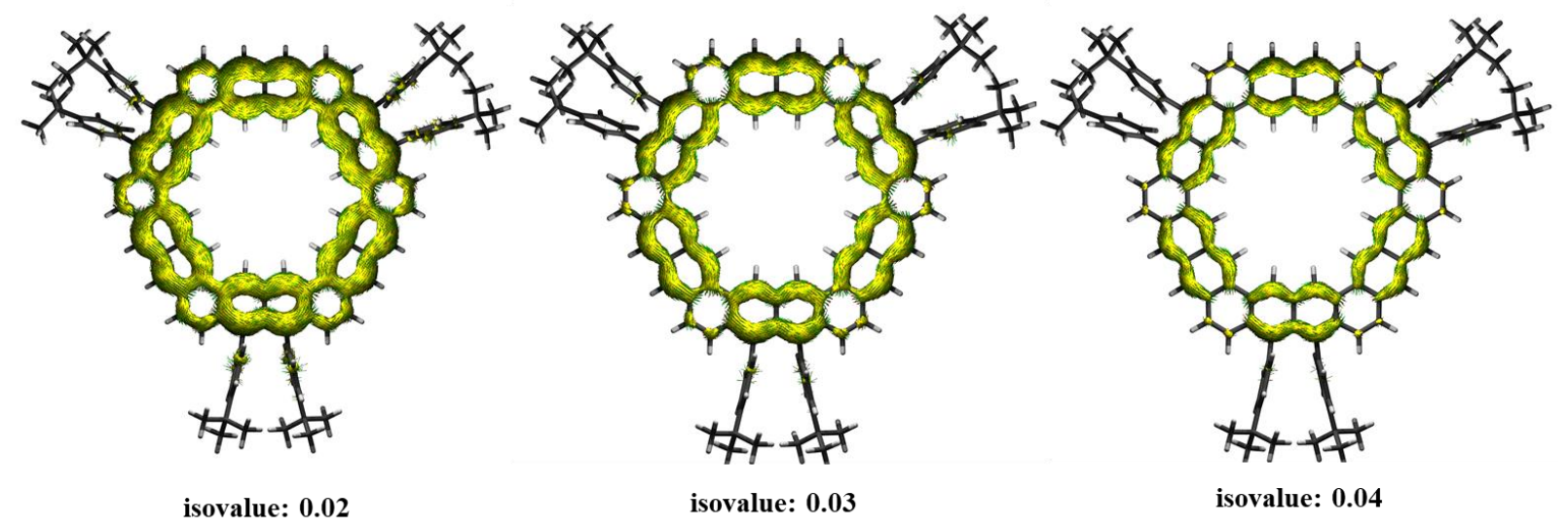

Figure S45. Calculated ACID plots of $[4,4] \mathrm{CA}$ with different isovalues.

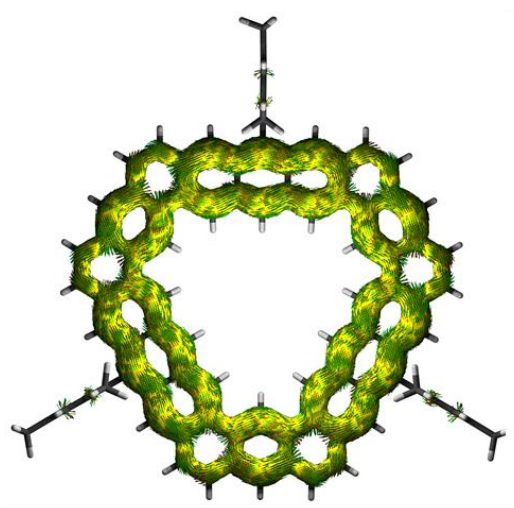

isovalue: 0.02

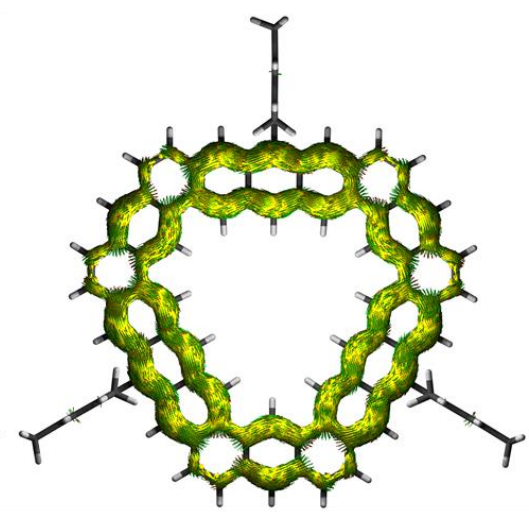

isovalue: $\mathbf{0 . 0 3}$

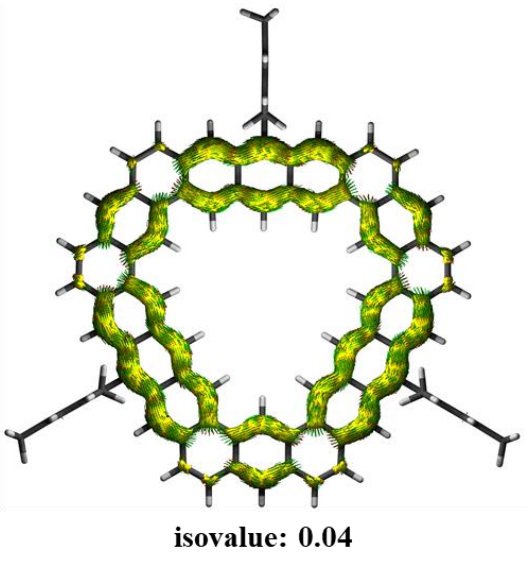

Figure S46. Calculated ACID plots of [3,5]CA with different isovalues. 


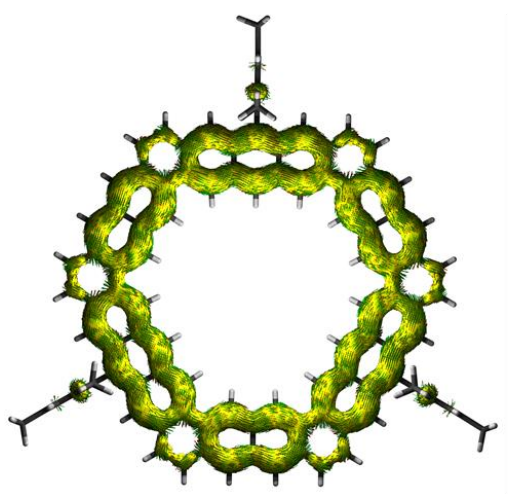

isovalue: 0.02

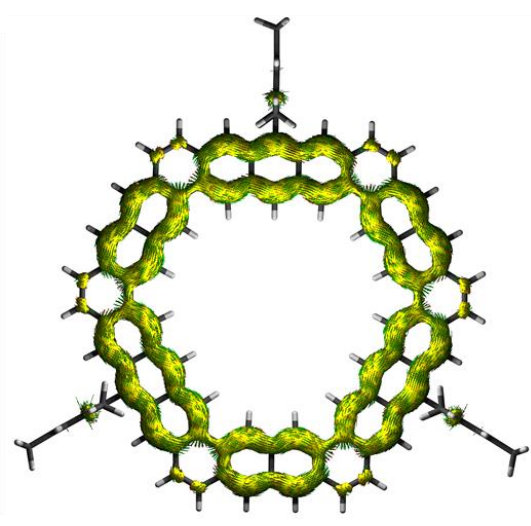

isovalue: 0.03

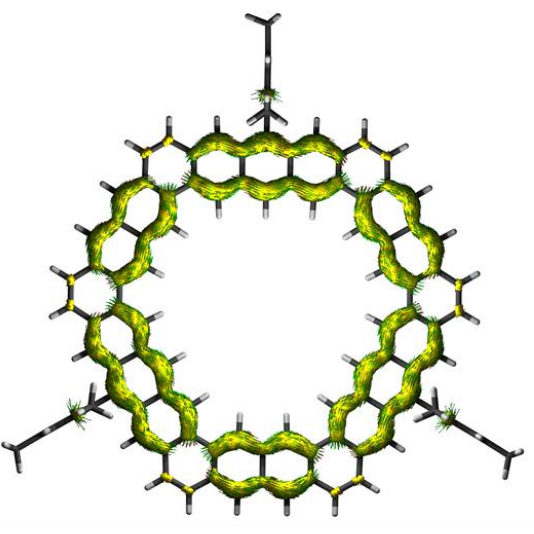

isovalue: 0.04

Figure S47. Calculated ACID plots of [4,5]CA with different isovalues.

(a)

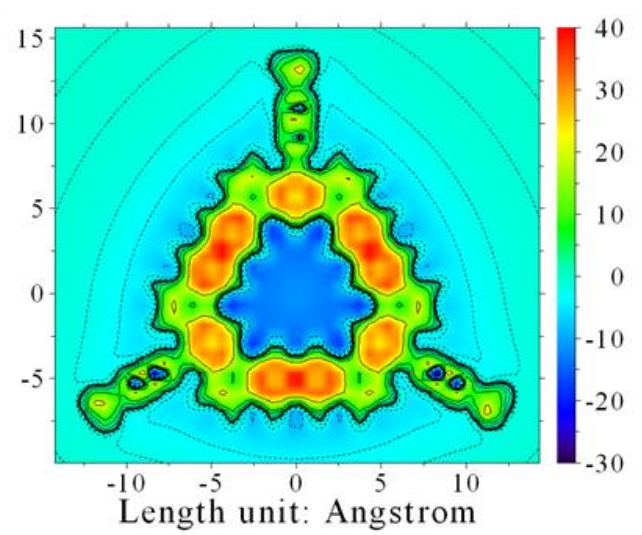

(b)

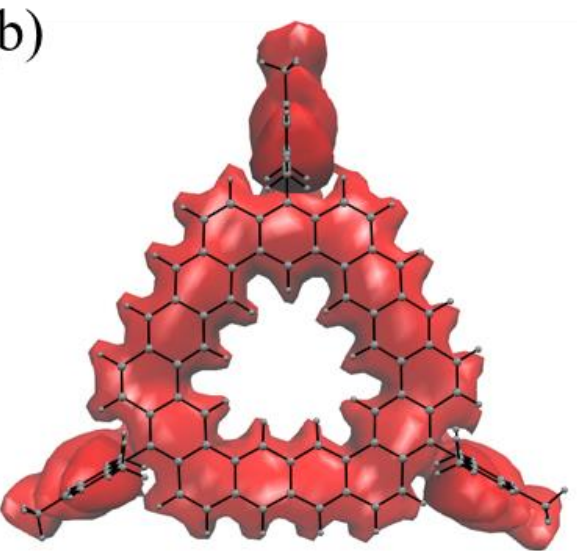

Figure S48. Calculated 2D ICSS (a) and 3D ICSS (b) maps of $[\mathbf{3 , 4}] \mathbf{C A - 2}$. The isovalue of 3D ICSS is 4 .

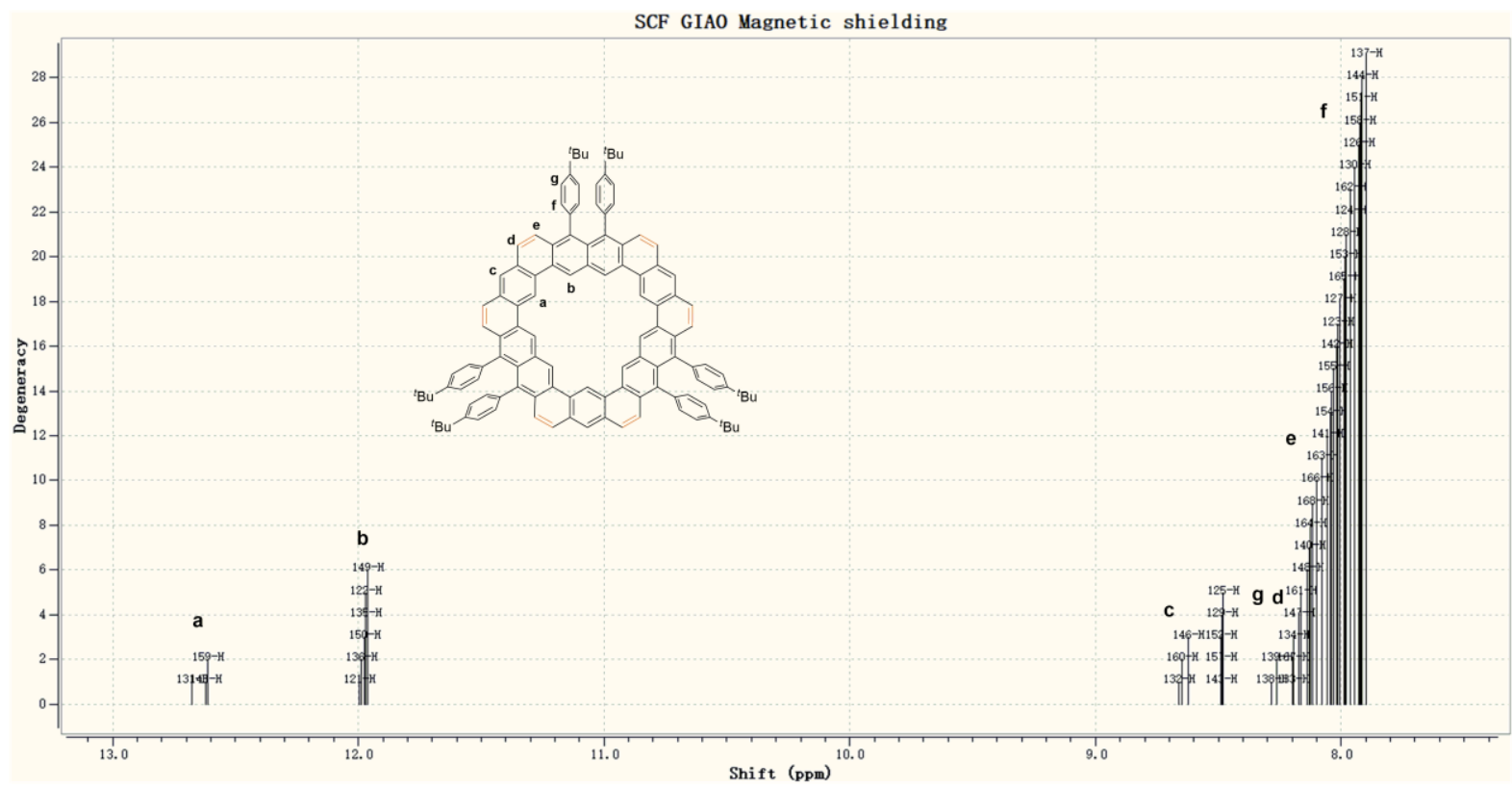

Figure S49. Calculated ${ }^{1} \mathrm{H}$ NMR spectrum of $[\mathbf{3 , 4}] \mathbf{C A}-1$ by $\mathrm{B} 3 \mathrm{LYP} / 6-31 \mathrm{G}(\mathrm{d}, \mathrm{p})$ GIAO method. 


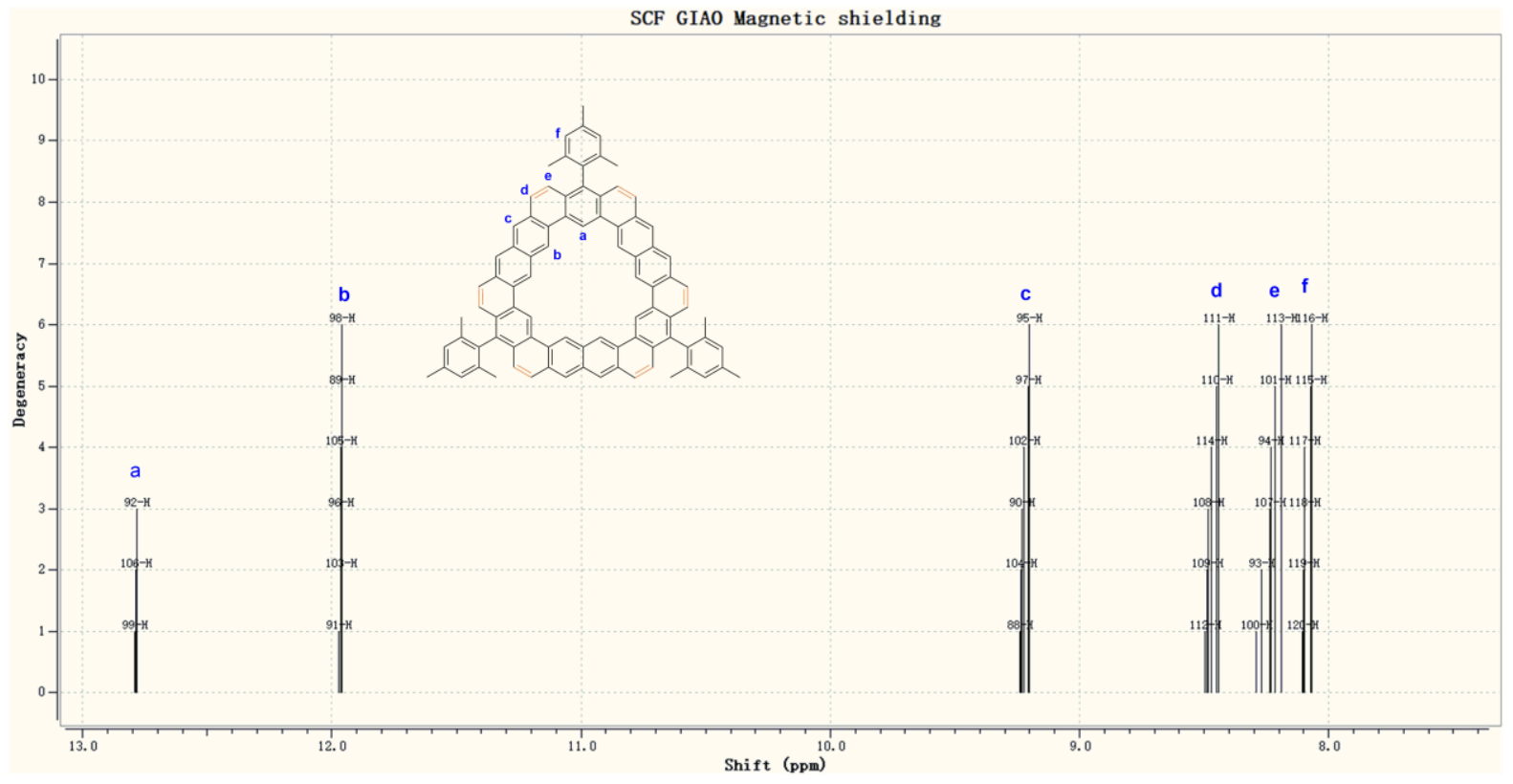

Figure S50. Calculated ${ }^{1} \mathrm{H}$ NMR spectrum of $[\mathbf{3 , 4}] \mathbf{C A}-2$ by B3LYP/6-31G(d,p) GIAO method.

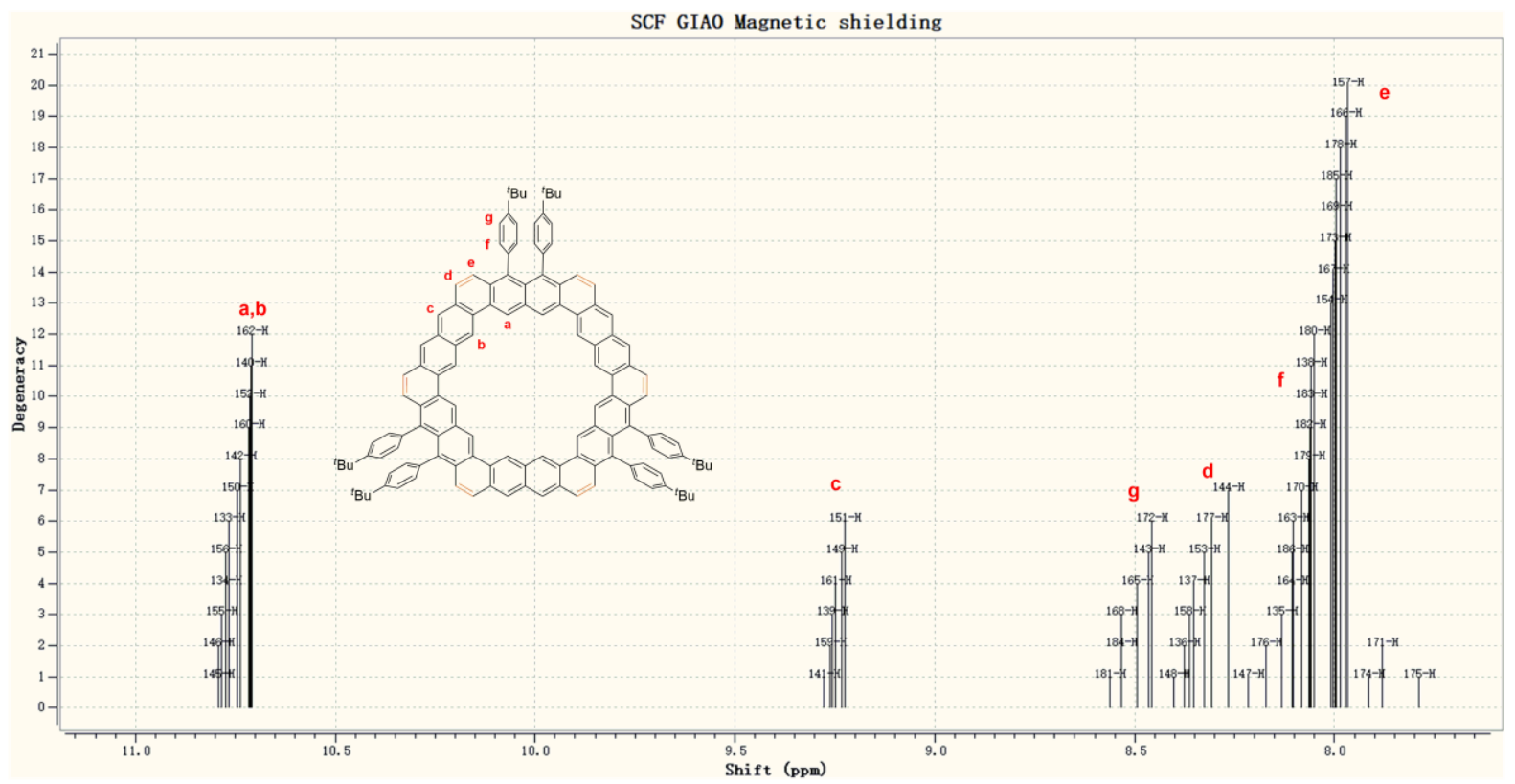

Figure S51. Calculated ${ }^{1} \mathrm{H}$ NMR spectrum of $[4,4]$ CA by B3LYP/6-31G(d,p) GIAO method. 


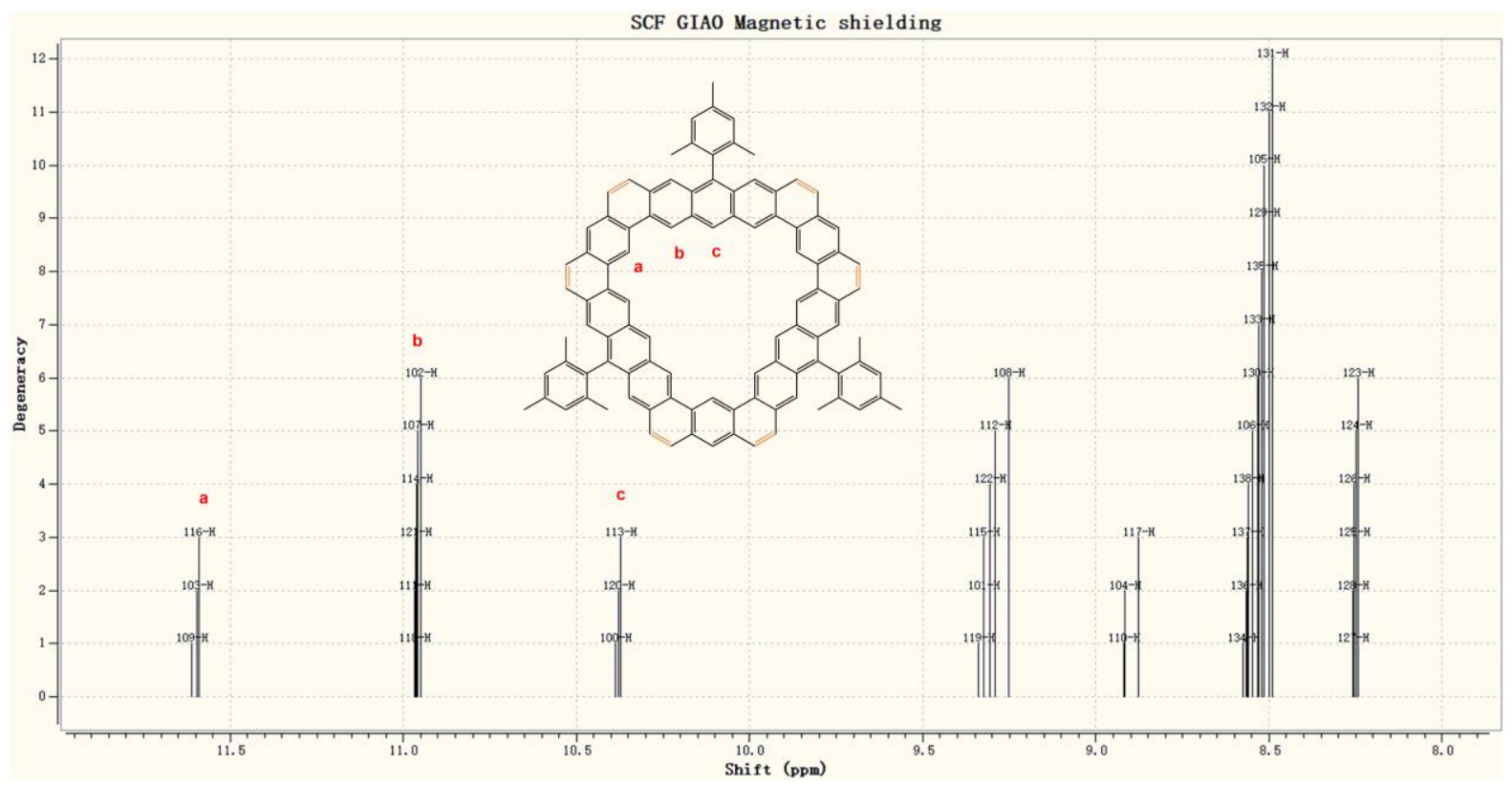

Figure S52. Calculated ${ }^{1} \mathrm{H}$ NMR spectrum of [3,5]CA by B3LYP/6-31G(d,p) GIAO method.

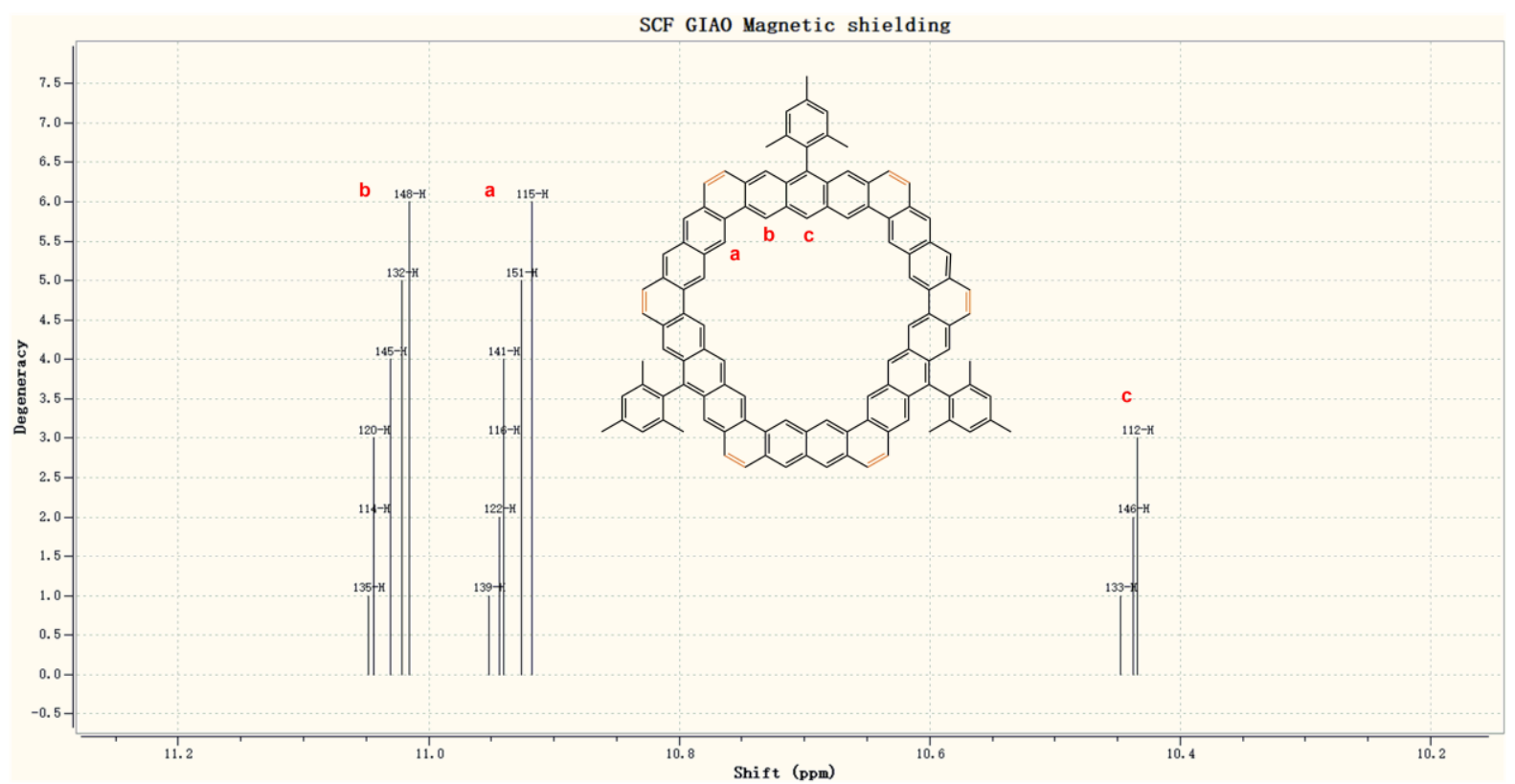

Figure S53. Calculated ${ }^{1} \mathrm{H}$ NMR spectrum of $[4,5]$ CA by B3LYP/6-31G(d,p) GIAO method. 


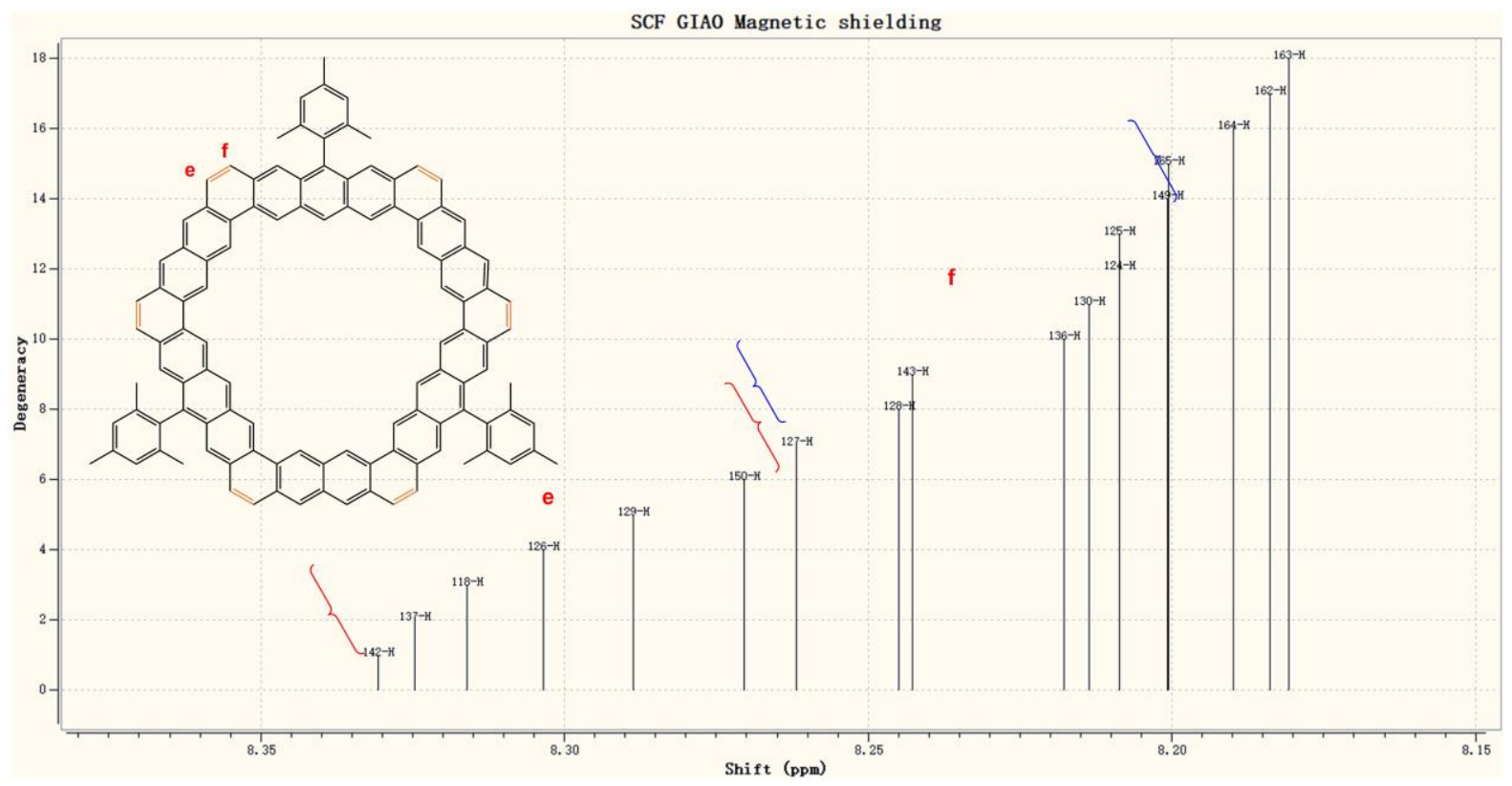

Figure S54. Calculated ${ }^{1} \mathrm{H}$ NMR spectrum of [4,5]CA by B3LYP/6-31G(d,p) GIAO method.

\section{X-ray crystallographic analysis}

Crystallographic data have been deposited with the Cambridge Crystallographic Data Centre as supplementary publication no. CCDC 2081432 (E) and 2081433 ([3,4]CA-1). The X-ray intensity data were measured at low temperature $(\mathrm{T}=100 \mathrm{~K})$, using a four circles goniometer Kappa geometry, Bruker AXS D8 Venture, equipped with a Photon 100 CMOS active pixel sensor detector. Frames were integrated with the Bruker SAINT8 software package. Data were corrected for absorption effects using the multi-scan method (SADABS). ${ }^{8}$ Molecule was solved with the software SHELXT, ${ }^{9}$ using a Dual Space method. Refinement of the structure was performed by least squares procedures on weighted F2 values using the SHELXL-version 2014/6 $6^{10}$ included in the WinGx system programs for Windows. ${ }^{11}$ The crystallographic data were summarized in Table S6.

Table S6. Crystallographic data of the two cycloarenes $\mathbf{E}$ and $[3,4] \mathbf{C A}-\mathbf{1}$.

$$
\text { E }
$$

$[3,4] \mathrm{CA}-1$

\begin{tabular}{ccc}
\hline Chemical formula & $\mathrm{C}_{36} \mathrm{H}_{44} \mathrm{~B}_{2} \mathrm{Cl}_{2} \mathrm{O}_{4}$ & $\mathrm{C}_{120} \mathrm{H}_{102}, \mathrm{C}_{4} \mathrm{H}_{8} \mathrm{O}$ \\
Formula weight & 633.23 & 1616.11 \\
Crystal system & orthorhombic & triclinic \\
Space group & $\mathrm{P} 2{ }_{1} 22_{1}$ & $\mathrm{P}-1$ \\
Calculated density & $1.188 \mathrm{Mg} / \mathrm{m}^{3}$ & $1.074 \mathrm{Mg} / \mathrm{m}^{3}$ \\
$a(\AA)$ & $12.6615(3)$ & $11.6155(8)$ \\
$b(\AA)$ & $14.3755(4)$ & $18.3314(12)$ \\
$c(\AA)$ & $19.4448(5)$ & $23.5382(13)$ \\
$\alpha\left(^{\circ}\right)$ & 90 & $91.266(4)$ \\
$\beta\left({ }^{\circ}\right)$ & 90 & $90.705(4)$ \\
$\gamma\left({ }^{\circ}\right)$ & 90 & $94.249(4)$ \\
Unit cell volume $\left(\AA^{3}\right)$ & $3539.25(16)$ & $4996.5(5)$
\end{tabular}


Temperature (K)

No. of formula units per unit cell
No. of reflections measured No. of independent reflections

$$
\text { Rint }
$$

Final R1 [I>2sigma(I)] (a)

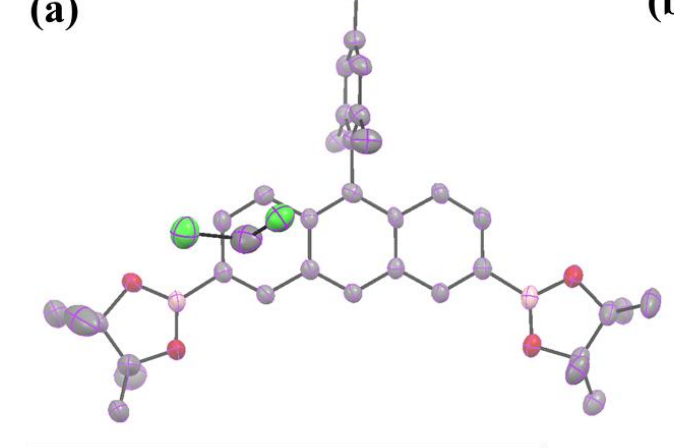

100

4

100

2

22623

6203

0.0786

0.0842

17023

0.1319

0.1317

Figure S55. Single crystal structures (a) top-view; (b) side-view of E. 


\section{6. ${ }^{1} \mathrm{H} /{ }^{13} \mathrm{C}$ NMR spectra and mass spectra}

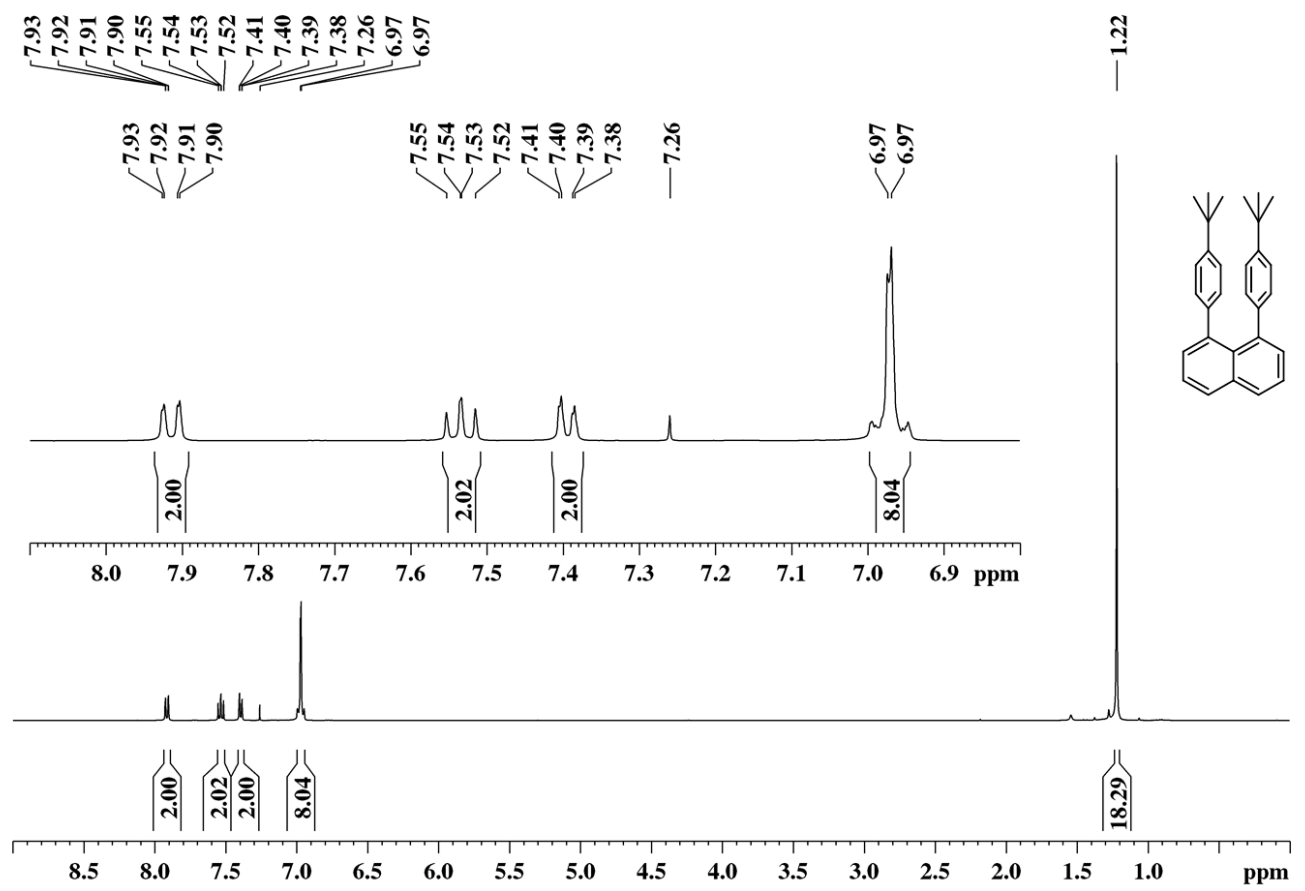

Figure S56. ${ }^{1} \mathrm{H}$ NMR spectrum of 5 in $\mathrm{CDCl}_{3}(400 \mathrm{MHz}, 298 \mathrm{~K})$

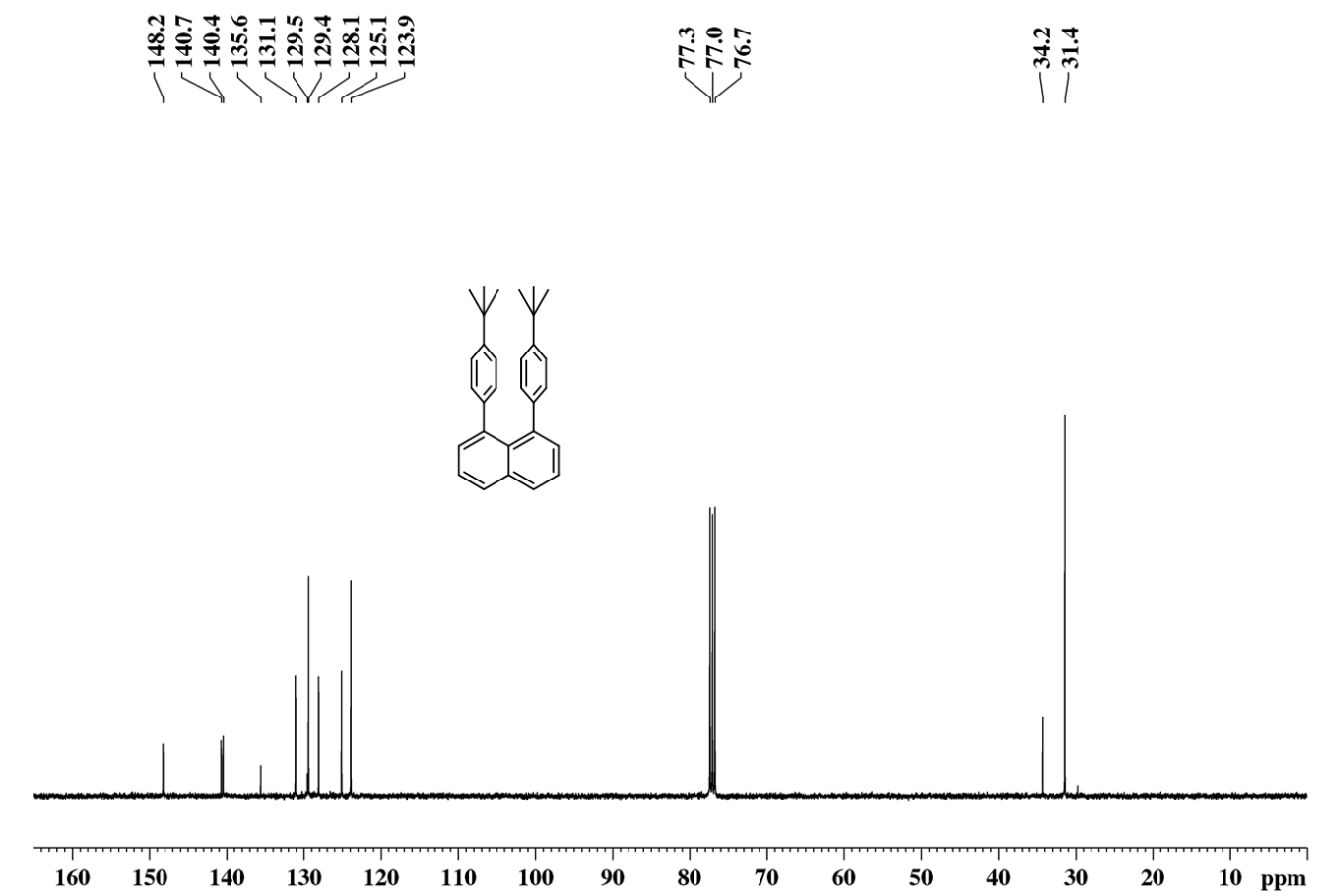

Figure S57. ${ }^{13} \mathrm{C}$ NMR spectrum of 5 in $\mathrm{CDCl}_{3}(100 \mathrm{MHz}, 298 \mathrm{~K})$ 


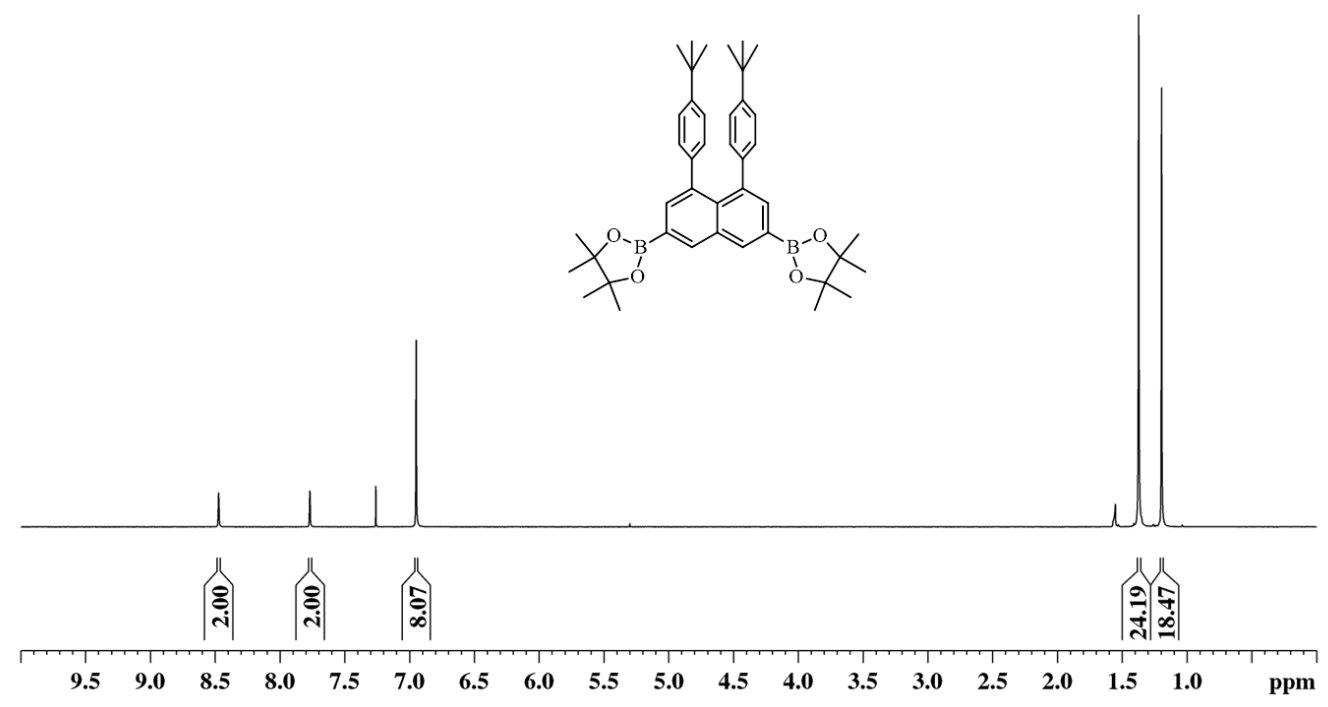

Figure S58. ${ }^{1} \mathrm{H}$ NMR spectrum of $\mathbf{D}$ in $\mathrm{CDCl}_{3}(400 \mathrm{MHz}, 298 \mathrm{~K})$

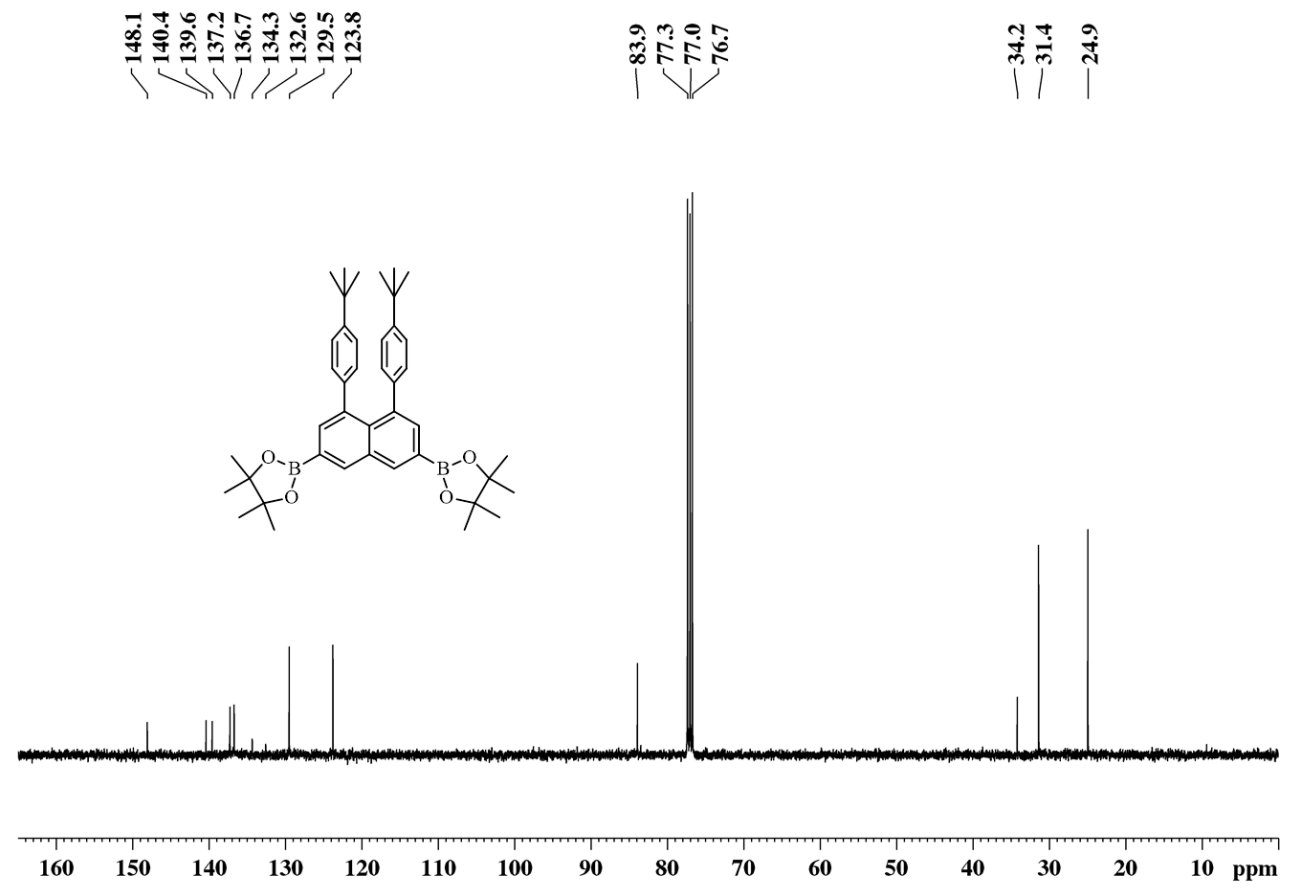

Figure S59. ${ }^{13} \mathrm{C}$ NMR spectrum of $\mathbf{D}$ in $\mathrm{CDCl}_{3}(100 \mathrm{MHz}, 298 \mathrm{~K})$ 


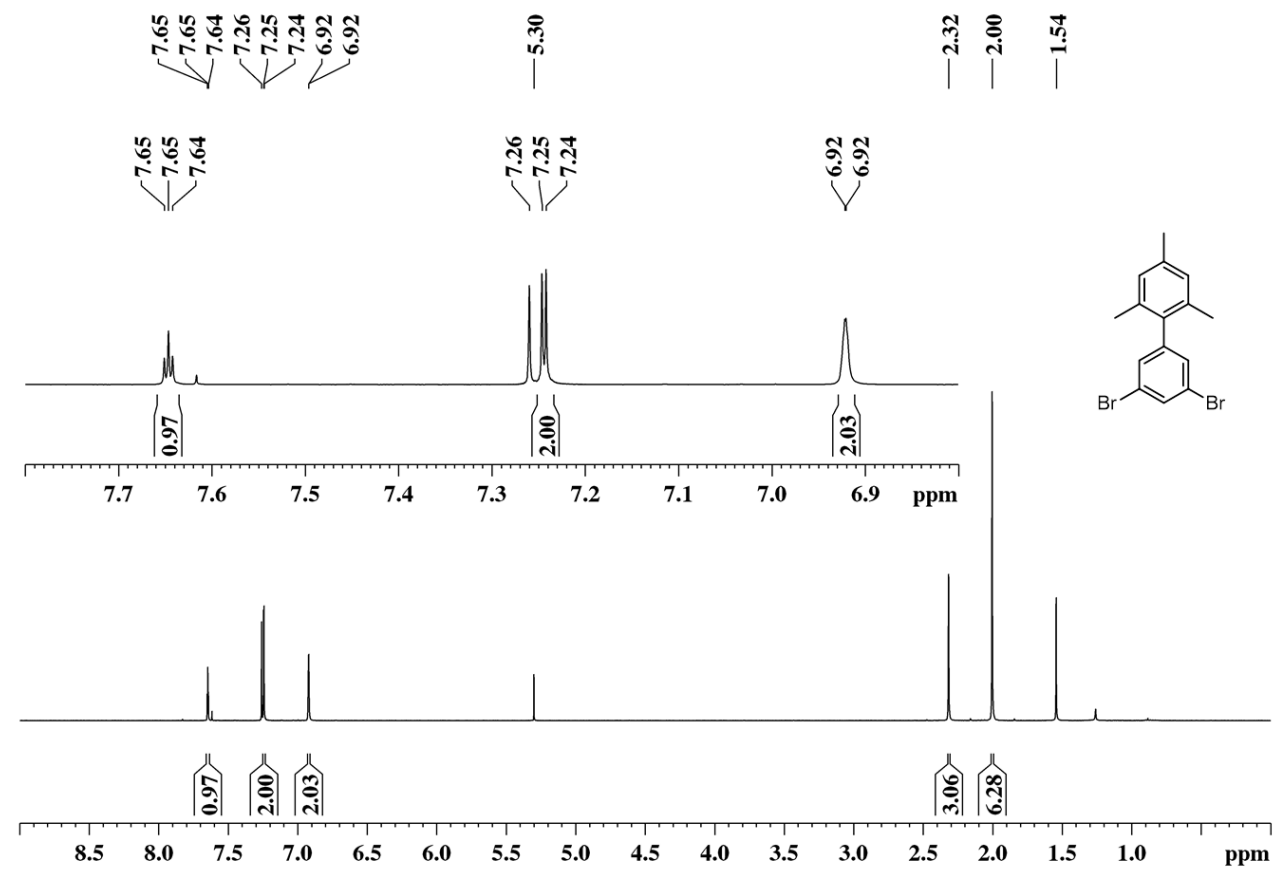

Figure S60. ${ }^{1} \mathrm{H}$ NMR spectrum of 9 in $\mathrm{CDCl}_{3}(400 \mathrm{MHz}, 298 \mathrm{~K})$

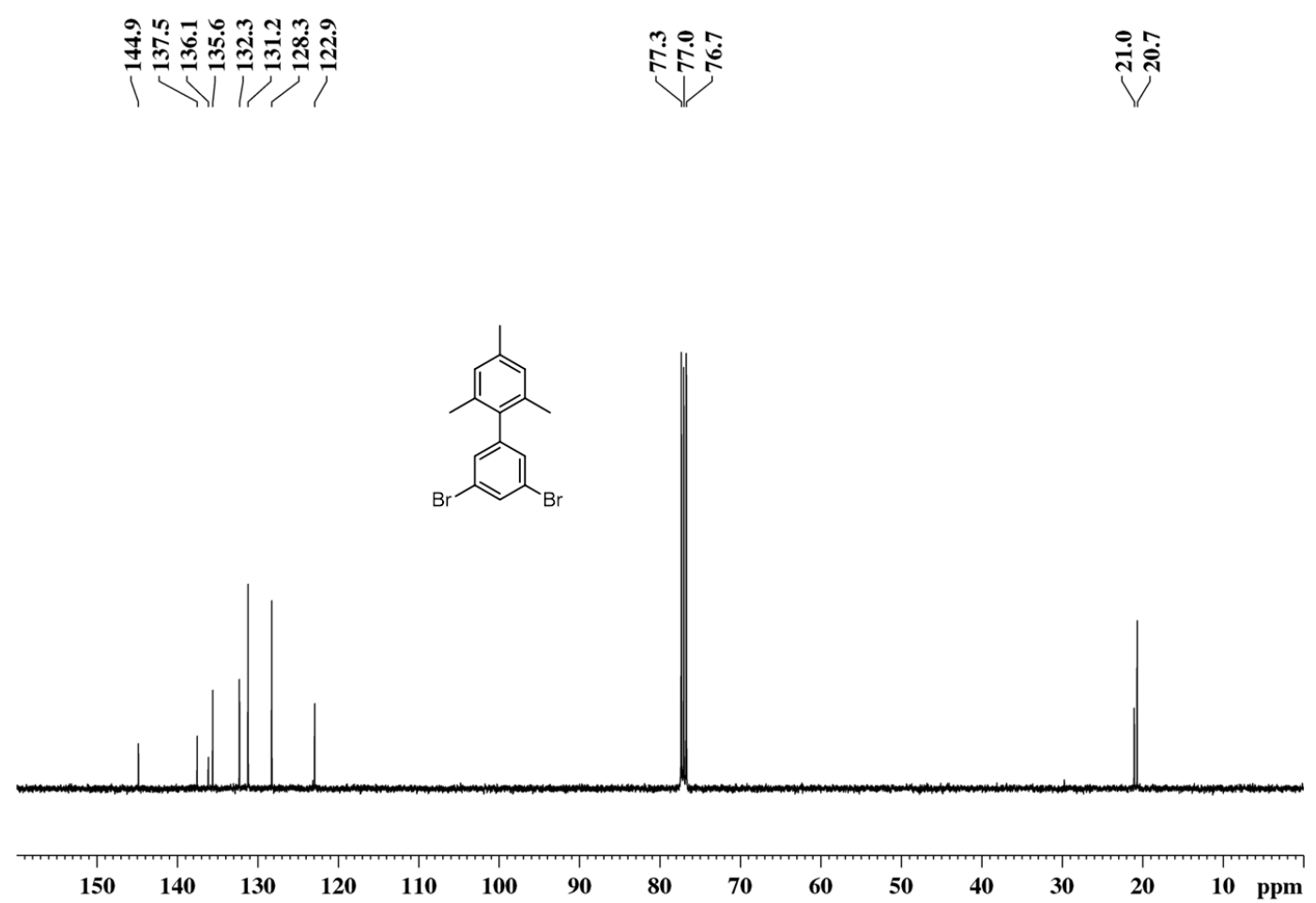

Figure S61. ${ }^{13} \mathrm{C}$ NMR spectrum of 9 in $\mathrm{CDCl}_{3}(100 \mathrm{MHz}, 298 \mathrm{~K})$ 


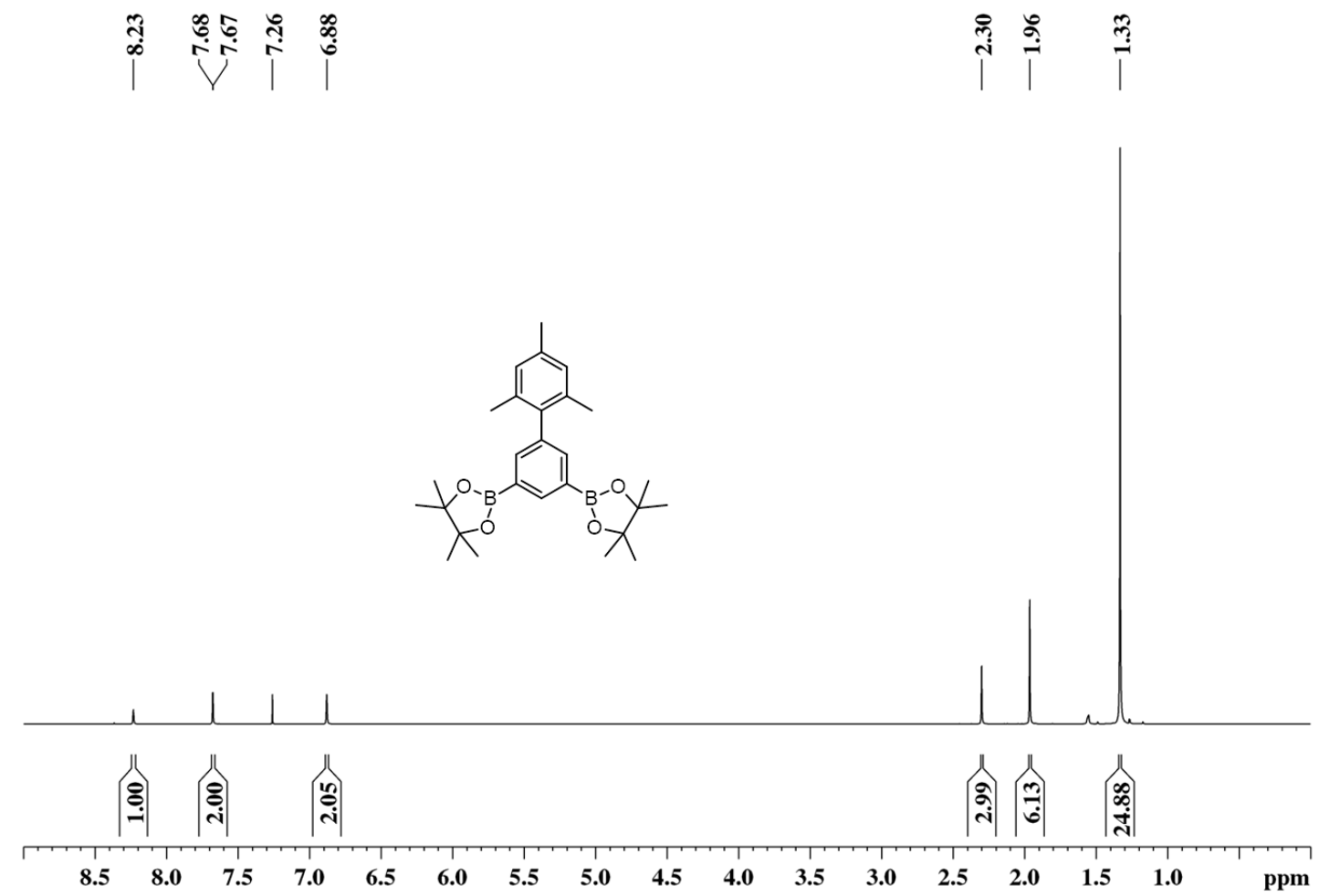

Figure S62. ${ }^{1} \mathrm{H}$ NMR spectrum of $\mathbf{C}$ in $\mathrm{CDCl}_{3}(400 \mathrm{MHz}, 298 \mathrm{~K})$

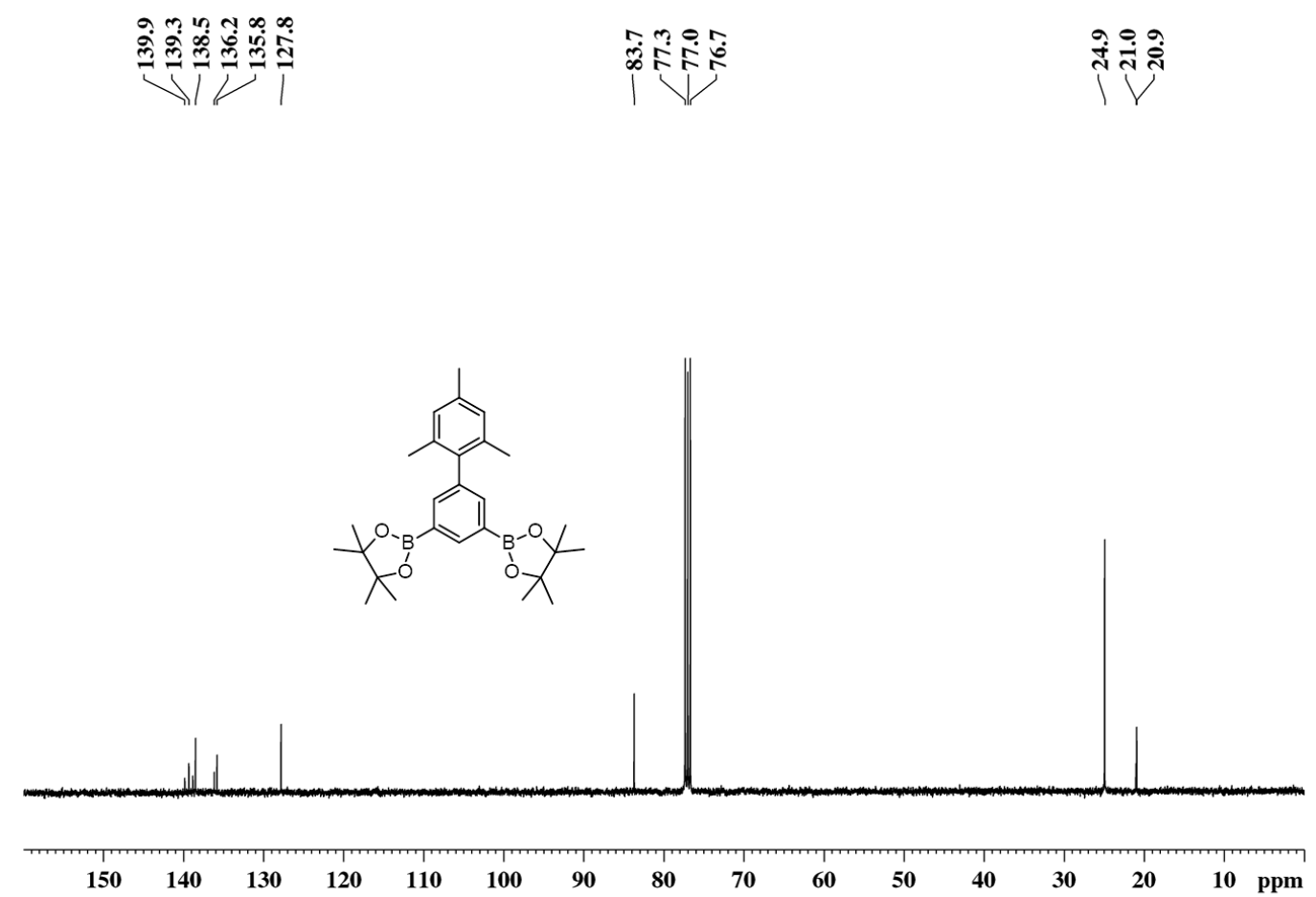

Figure S63. ${ }^{13} \mathrm{C}$ NMR spectrum of $\mathbf{C}$ in $\mathrm{CDCl}_{3}(100 \mathrm{MHz}, 298 \mathrm{~K})$ 
<smiles>CCOC=Cc1cc2cc(C=COCC)c(O)cc2cc1O</smiles>

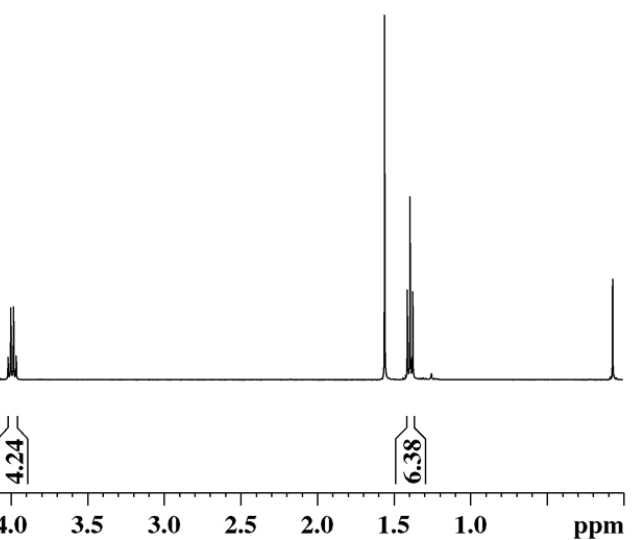

Figure S64. ${ }^{1} \mathrm{H}$ NMR spectrum of $\mathbf{B}$ in $\mathrm{CDCl}_{3}(400 \mathrm{MHz}, 298 \mathrm{~K})$
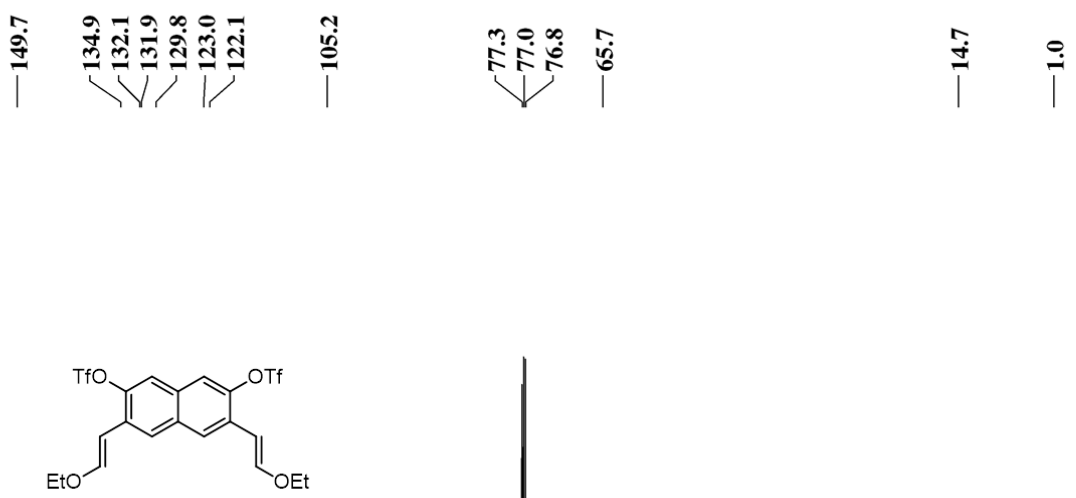

$\begin{array}{llllllllllllllllll}170 & 160 & 150 & 140 & 130 & 120 & 110 & 100 & 90 & 80 & 70 & 60 & 50 & 40 & 30 & 20 & 10 & 0\end{array}$

Figure S65. ${ }^{13} \mathrm{C}$ NMR spectrum of $\mathbf{B}$ in $\mathrm{CDCl}_{3}(100 \mathrm{MHz}, 298 \mathrm{~K})$ 

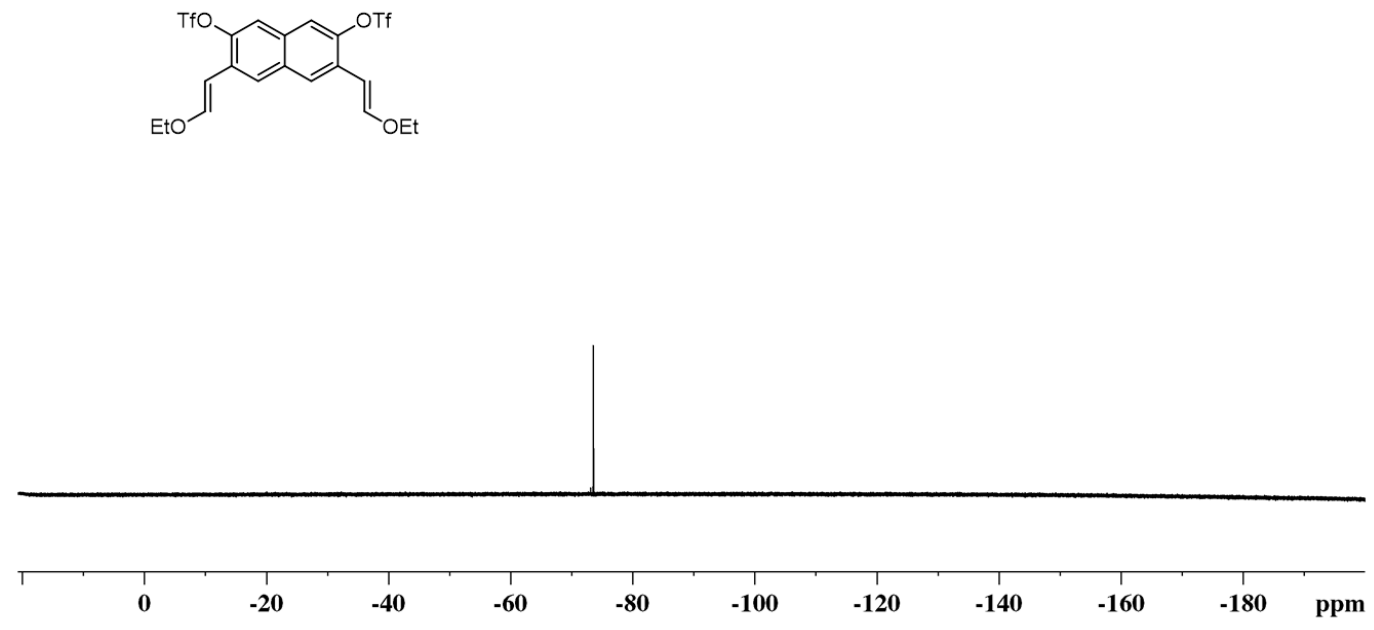

Figure S66. ${ }^{19} \mathrm{~F}$ NMR spectrum of $\mathbf{B}$ in $\mathrm{CDCl}_{3}(377 \mathrm{MHz}, 298 \mathrm{~K})$

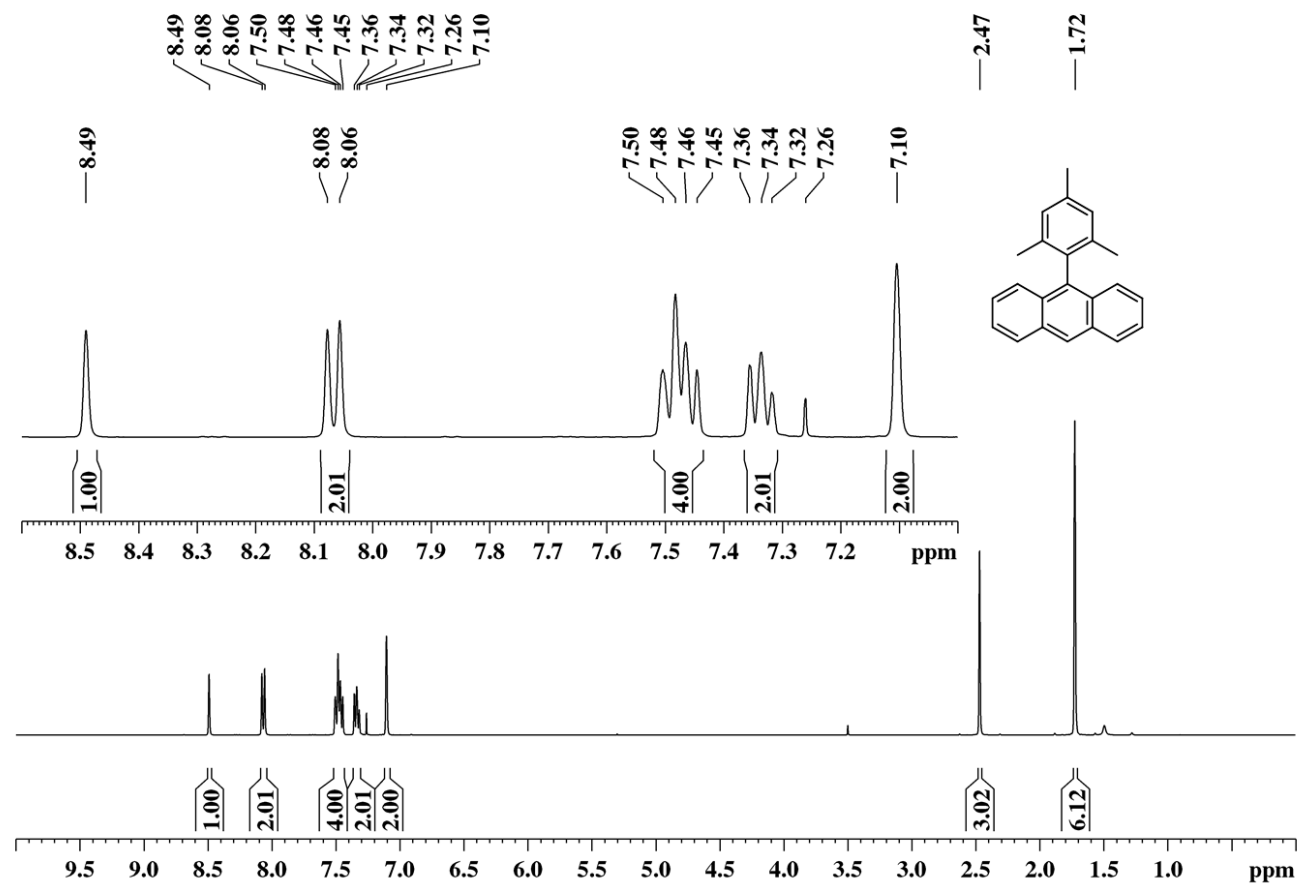

Figure S67. ${ }^{1} \mathrm{H}$ NMR spectrum of 8 in $\mathrm{CDCl}_{3}(400 \mathrm{MHz}, 298 \mathrm{~K})$ 


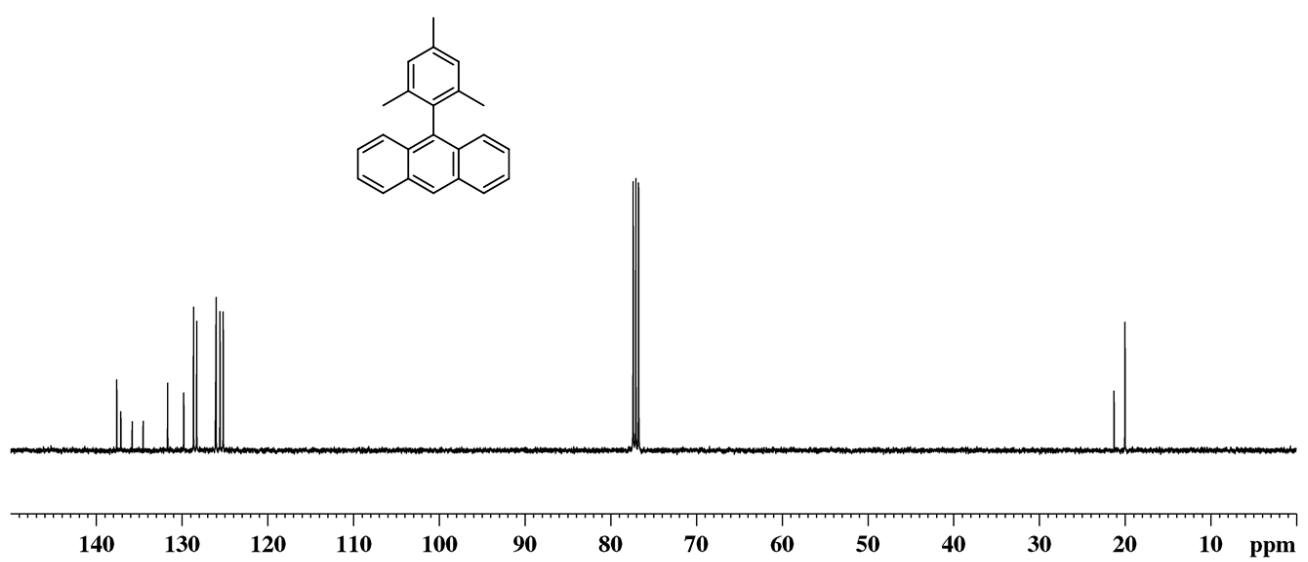

Figure S68. ${ }^{13} \mathrm{C}$ NMR spectrum of 8 in $\mathrm{CDCl}_{3}(100 \mathrm{MHz}, 298 \mathrm{~K})$

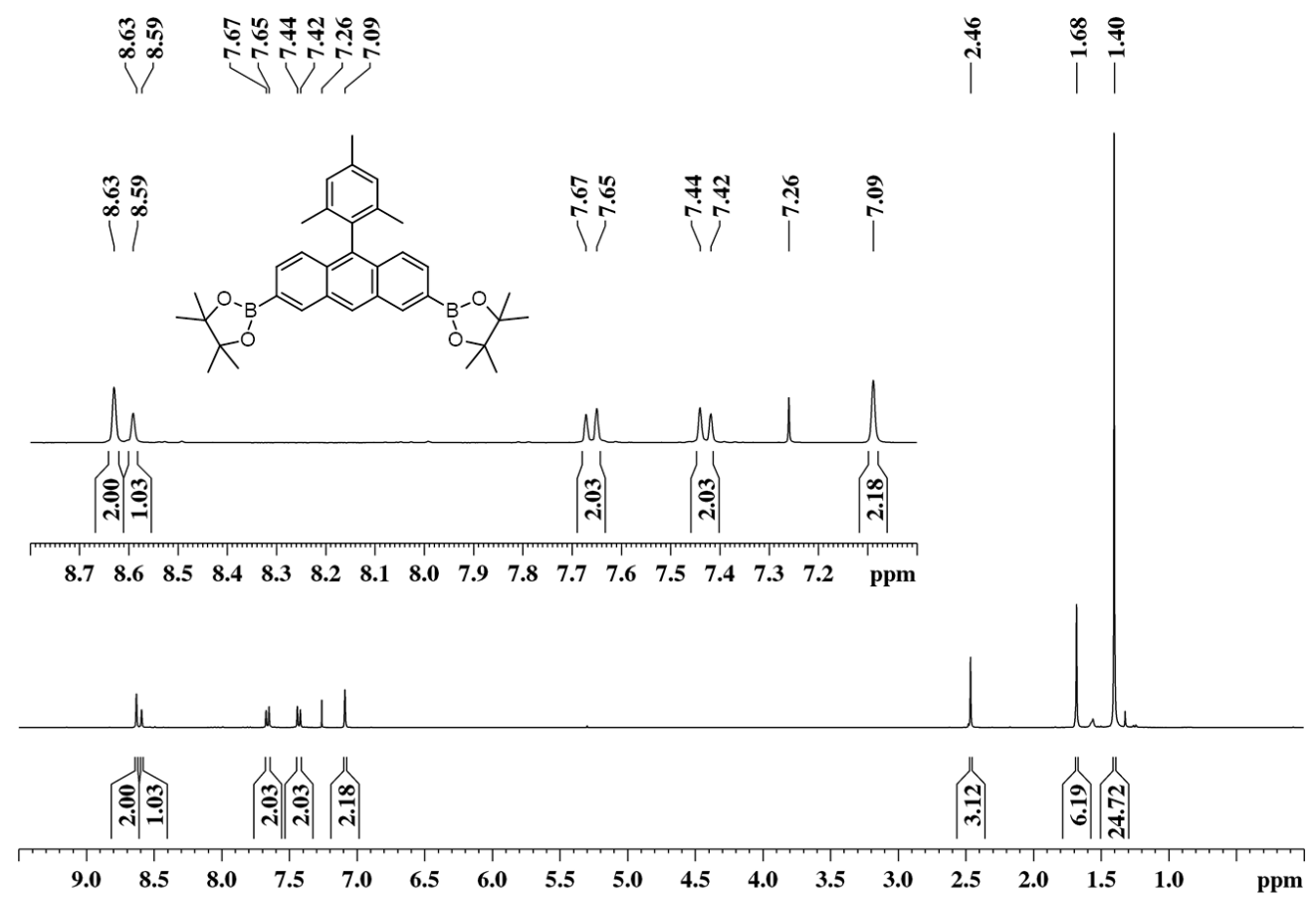

Figure S69. ${ }^{1} \mathrm{H}$ NMR spectrum of $\mathbf{E}$ in $\mathrm{CDCl}_{3}(400 \mathrm{MHz}, 298 \mathrm{~K})$ 


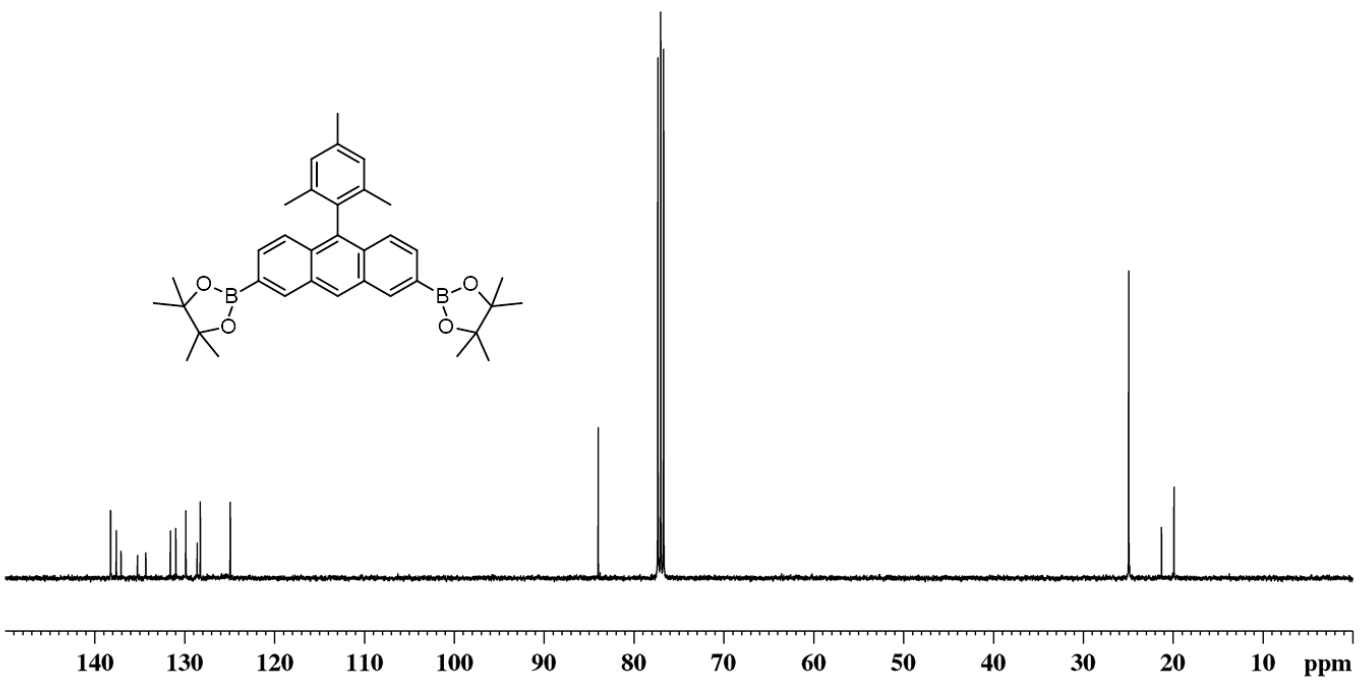

Figure S70. ${ }^{13} \mathrm{C}$ NMR spectrum of $\mathbf{E}$ in $\mathrm{CDCl}_{3}(100 \mathrm{MHz}, 298 \mathrm{~K})$

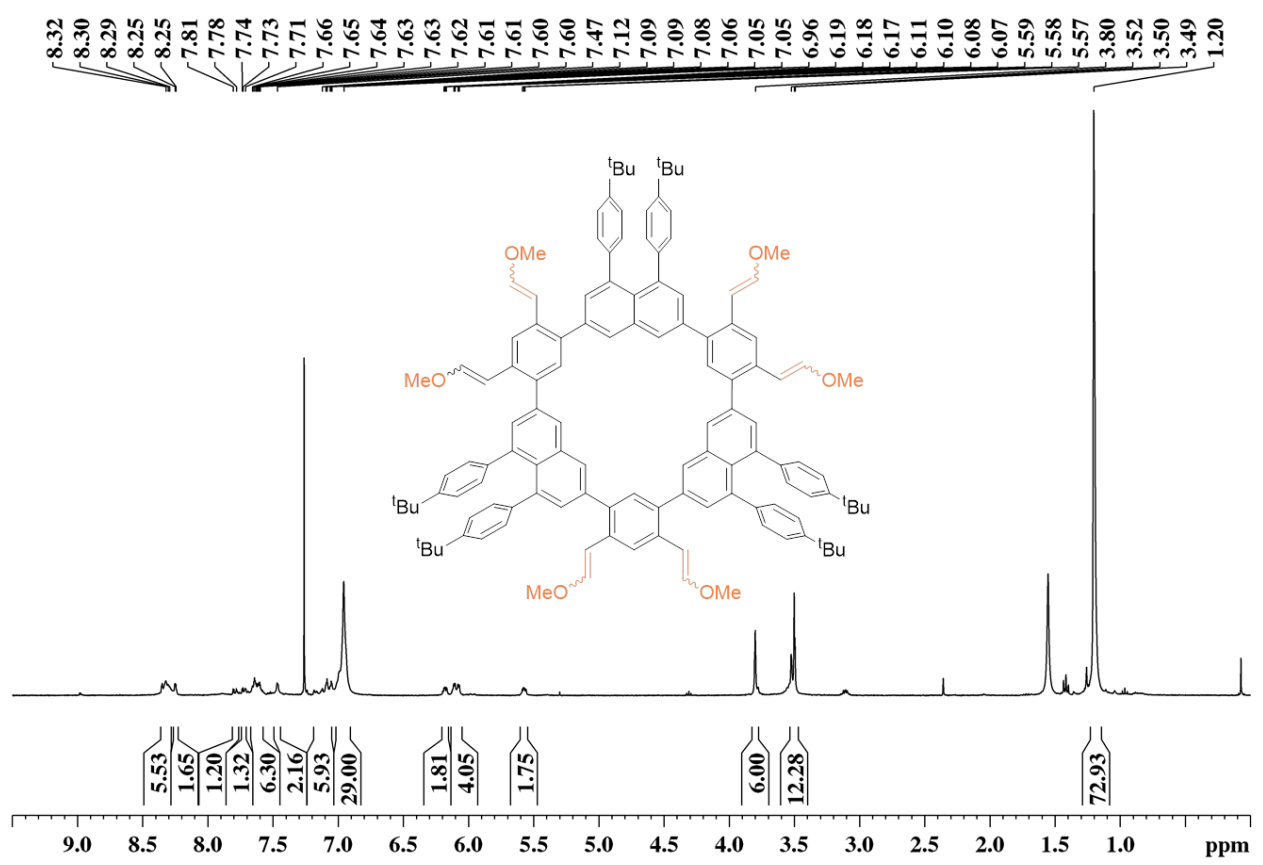

Figure S71. ${ }^{1} \mathrm{H}$ NMR spectrum of $\mathbf{1 0}$ in $\mathrm{CDCl}_{3}(400 \mathrm{MHz}, 298 \mathrm{~K})$ 


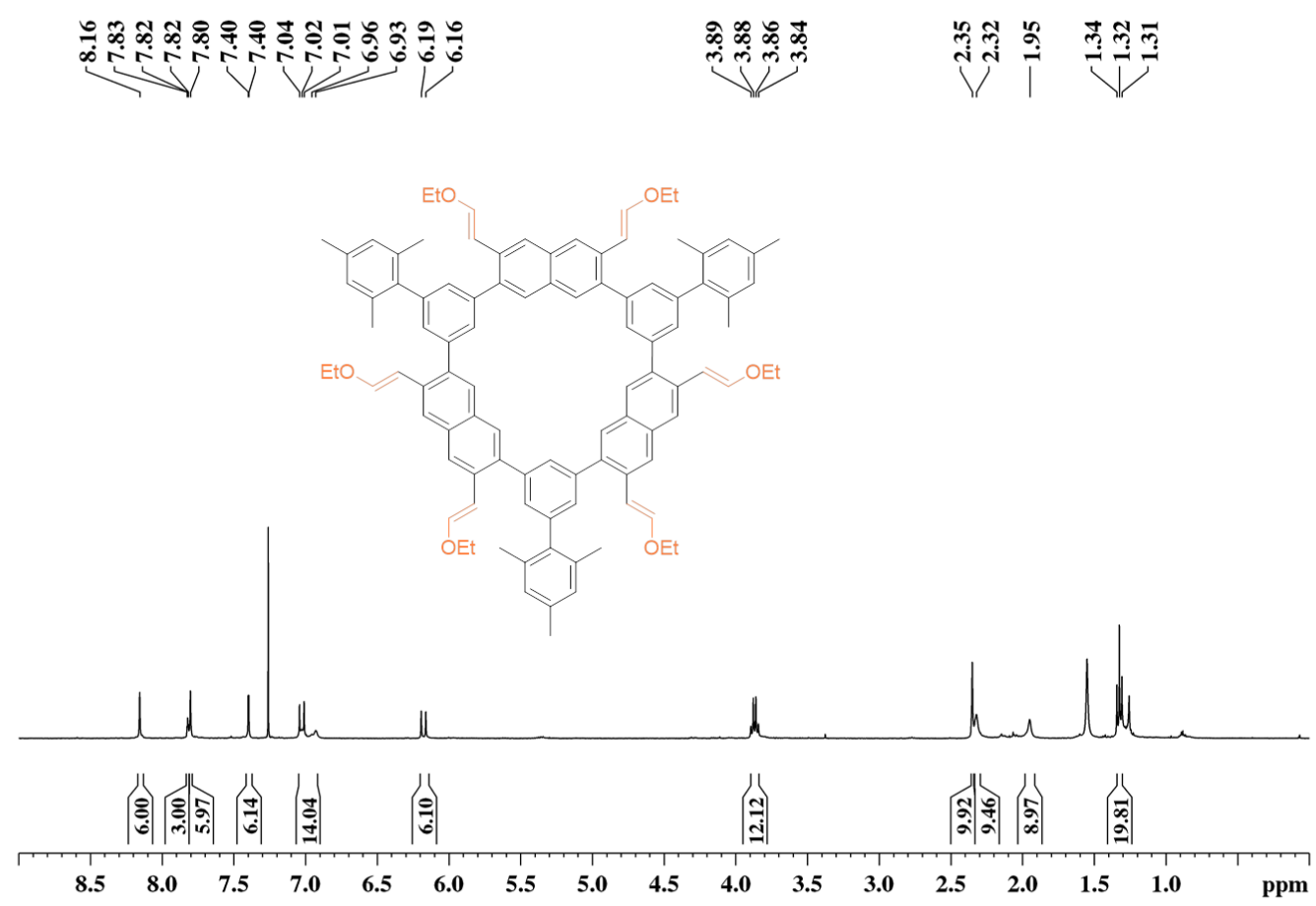

Figure S72. ${ }^{1} \mathrm{H}$ NMR spectrum of 11 in $\mathrm{CDCl}_{3}(400 \mathrm{MHz}, 298 \mathrm{~K})$

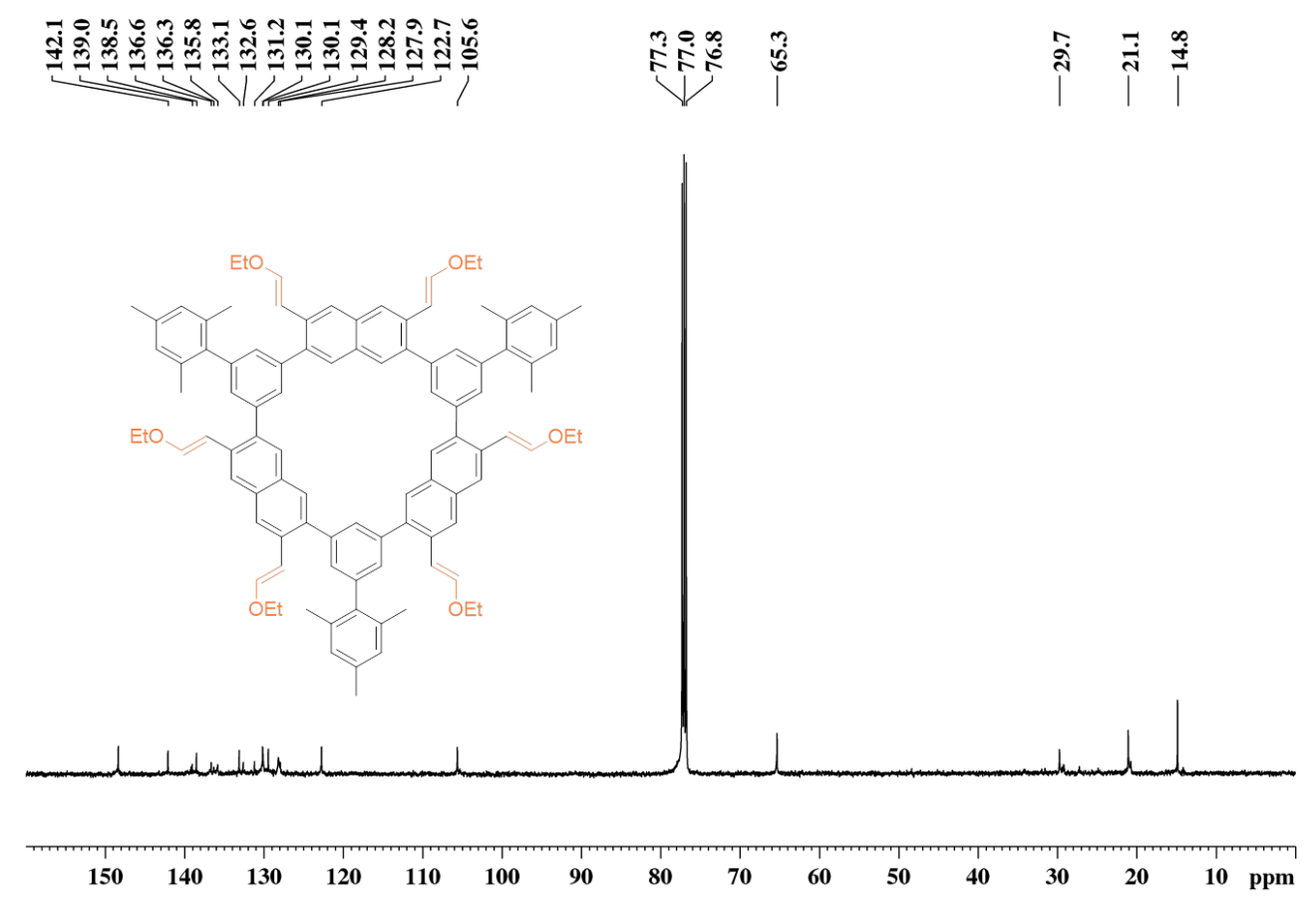

Figure S73. ${ }^{13} \mathrm{C}$ NMR spectrum of $\mathbf{1 1}$ in $\mathrm{CDCl}_{3}(100 \mathrm{MHz}, 298 \mathrm{~K})$ 


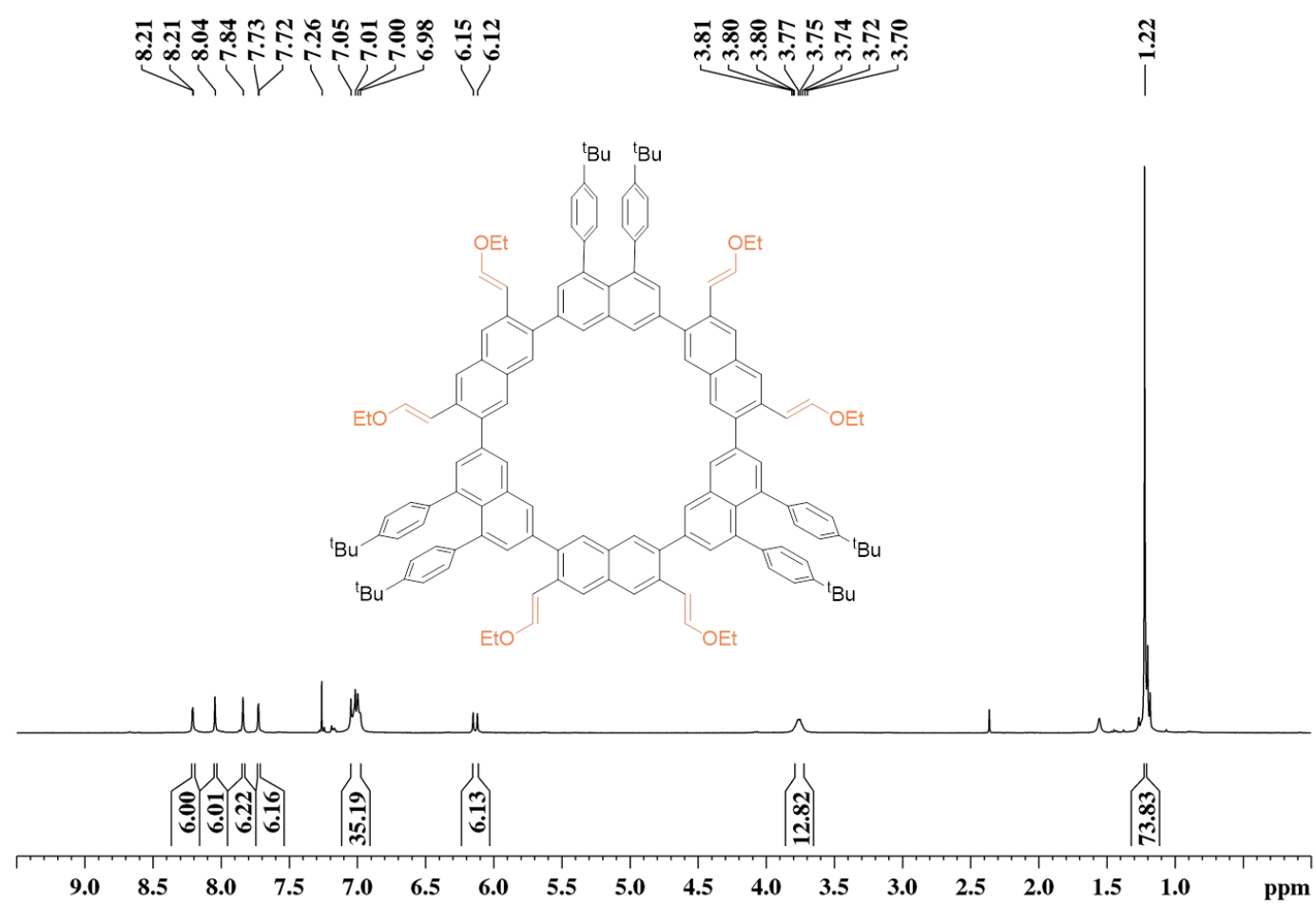

Figure S74. ${ }^{1} \mathrm{H}$ NMR spectrum of 12 in $\mathrm{CDCl}_{3}(400 \mathrm{MHz}, 298 \mathrm{~K})$

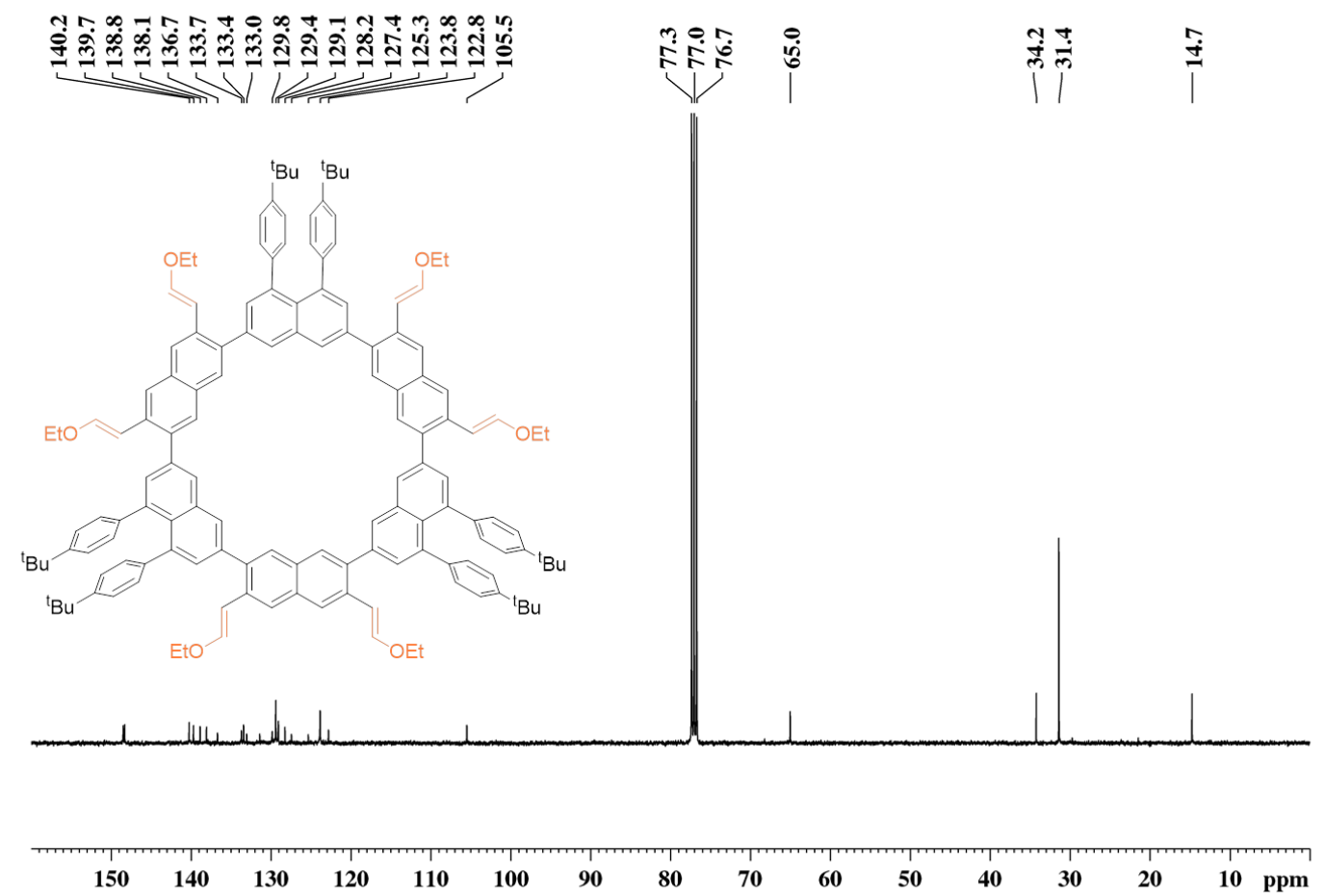

Figure S75. ${ }^{13} \mathrm{C}$ NMR spectrum of 12 in $\mathrm{CDCl}_{3}(100 \mathrm{MHz}, 298 \mathrm{~K})$ 


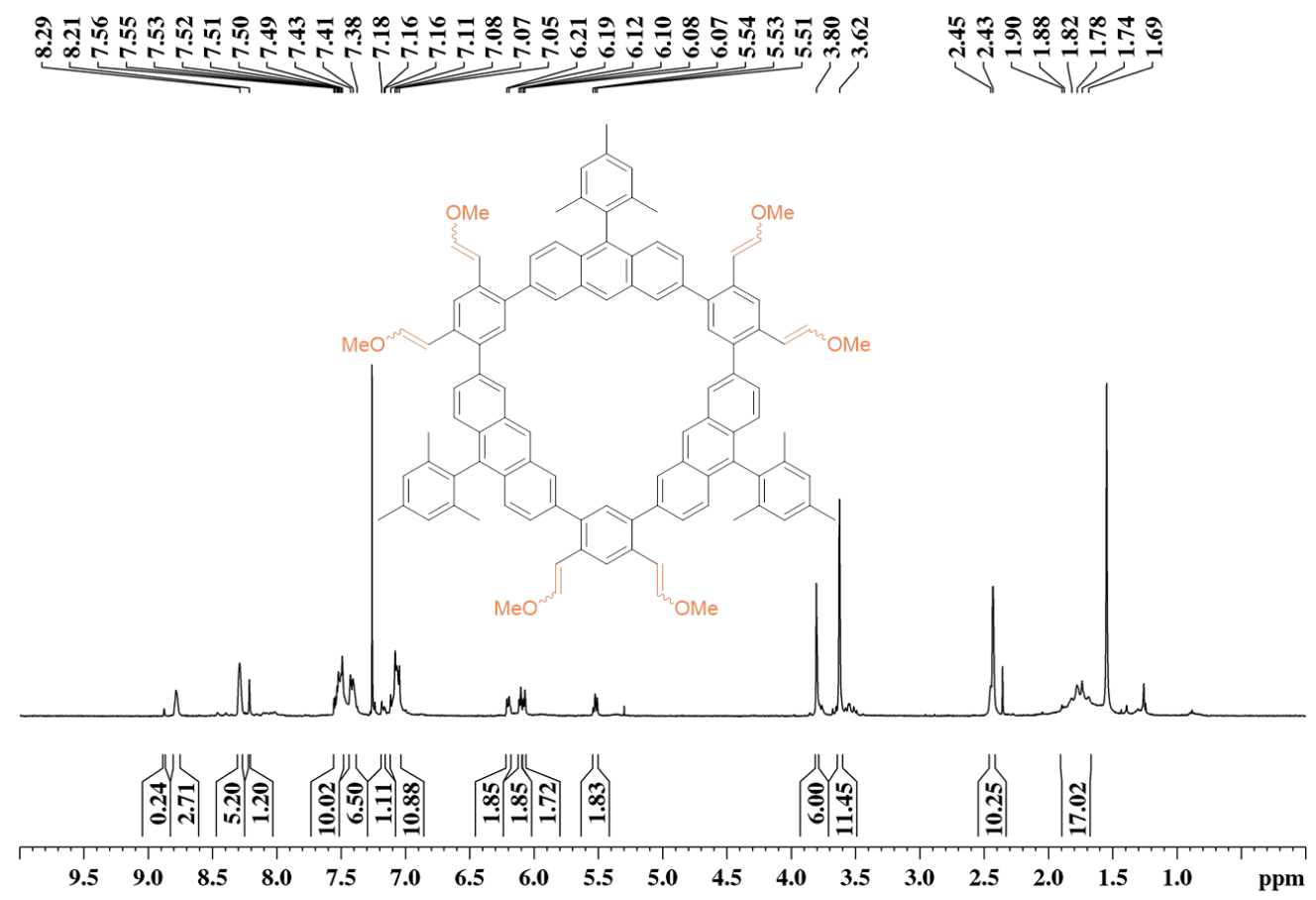

Figure S76. ${ }^{1} \mathrm{H}$ NMR spectrum of $\mathbf{1 3}$ in $\mathrm{CDCl}_{3}(400 \mathrm{MHz}, 298 \mathrm{~K})$

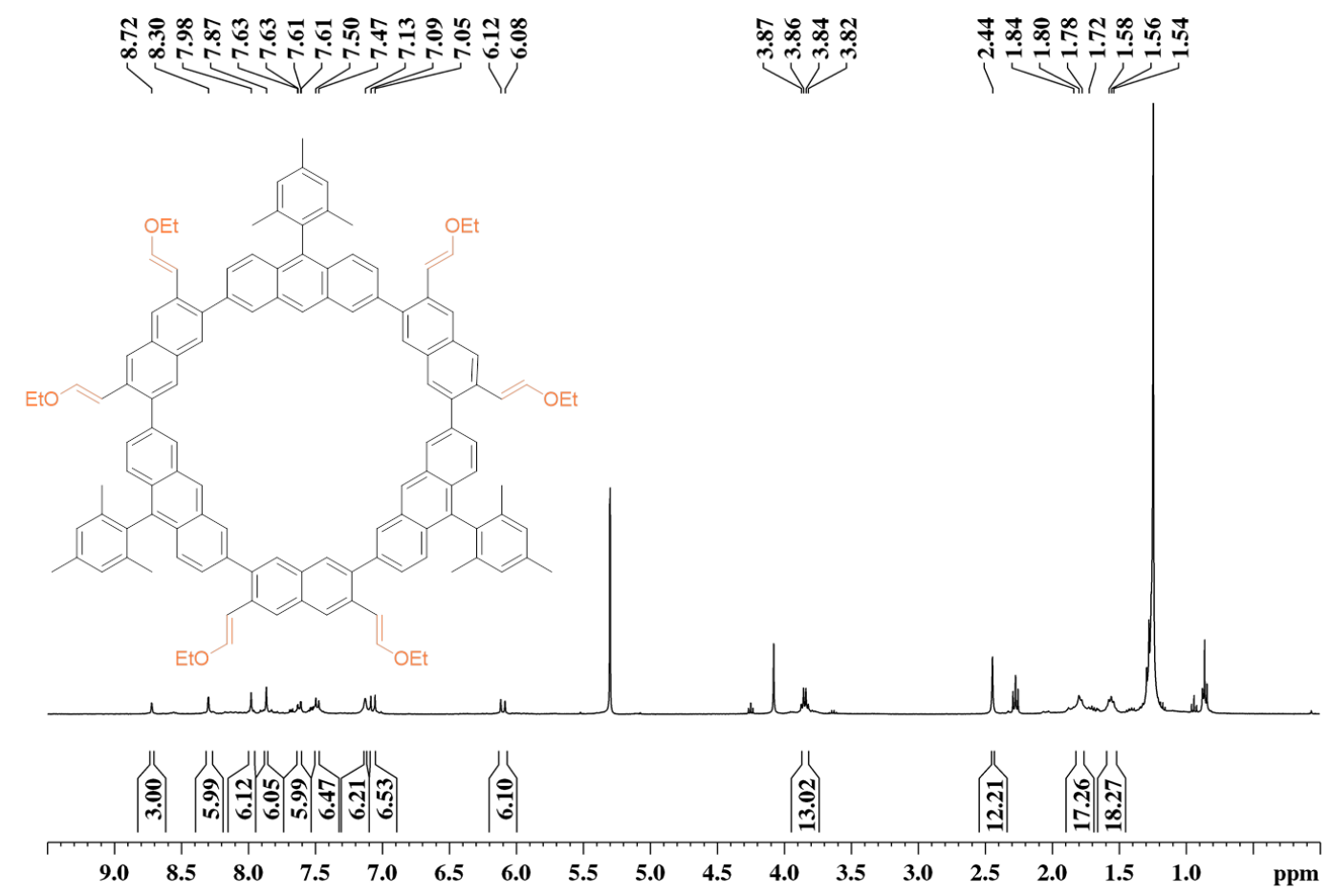

Figure S77. ${ }^{1} \mathrm{H}$ NMR spectrum of 14 in $\mathrm{CD}_{2} \mathrm{Cl}_{2}(400 \mathrm{MHz}, 298 \mathrm{~K})$ 


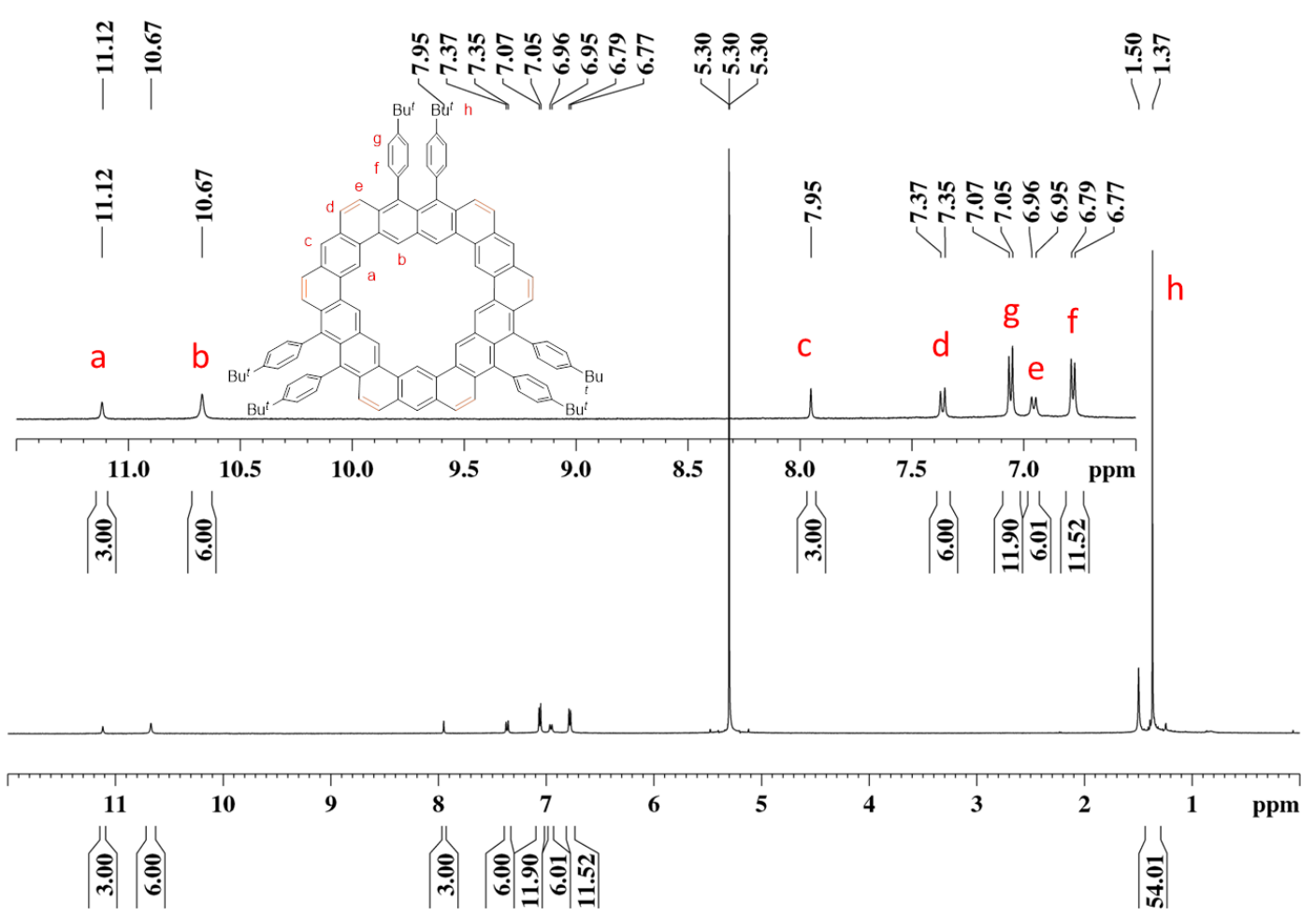

Figure S78. ${ }^{1} \mathrm{H}$ NMR spectrum of $[\mathbf{3 , 4}] \mathbf{C A}-\mathbf{1}$ in $\mathrm{CD}_{2} \mathrm{Cl}_{2}(500 \mathrm{MHz}, 298 \mathrm{~K})$

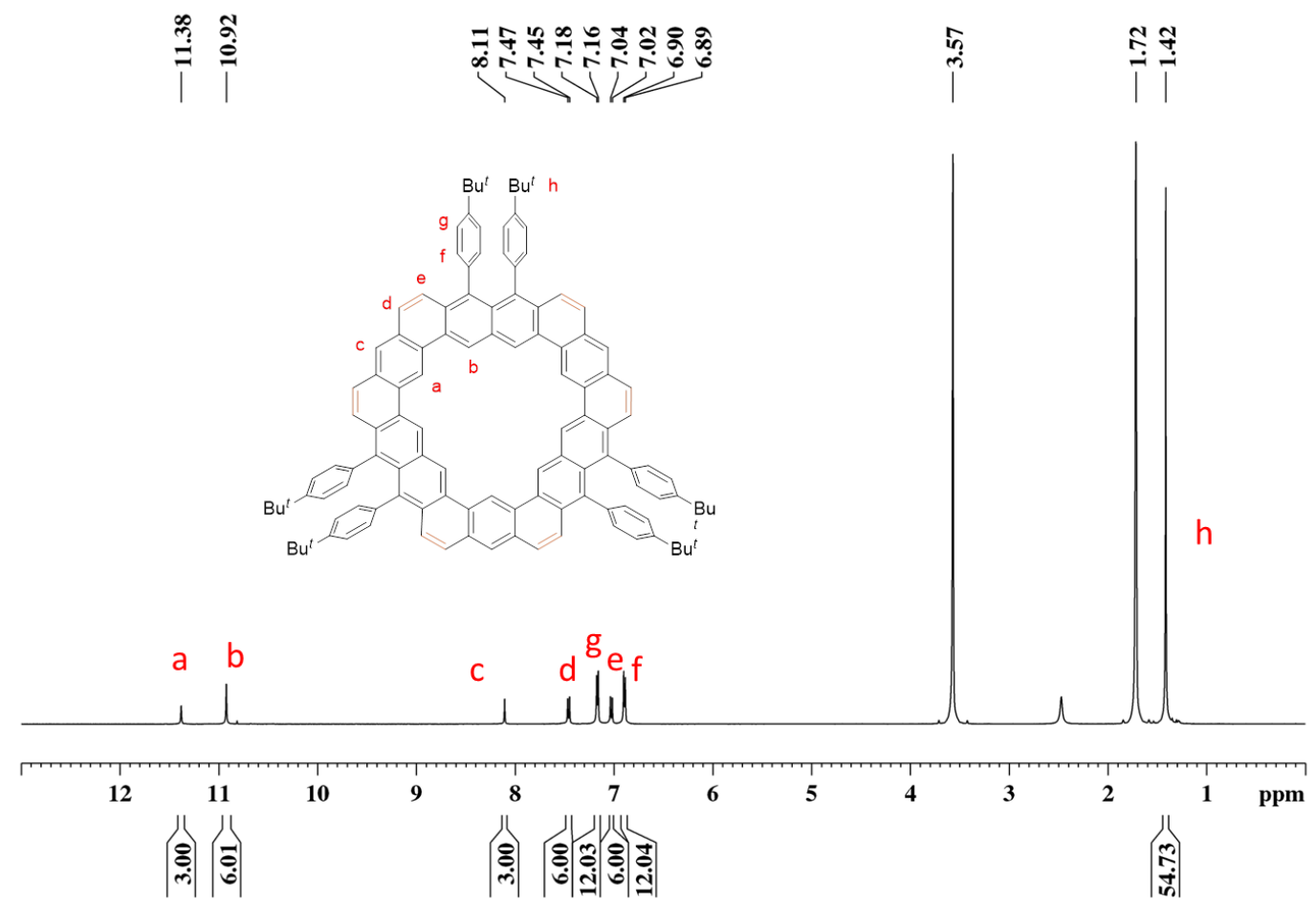

Figure S79. ${ }^{1} \mathrm{H}$ NMR spectrum of $[\mathbf{3 , 4}] \mathbf{C A}-\mathbf{1}$ in THF- $d_{8}(500 \mathrm{MHz}, 298 \mathrm{~K})$ 


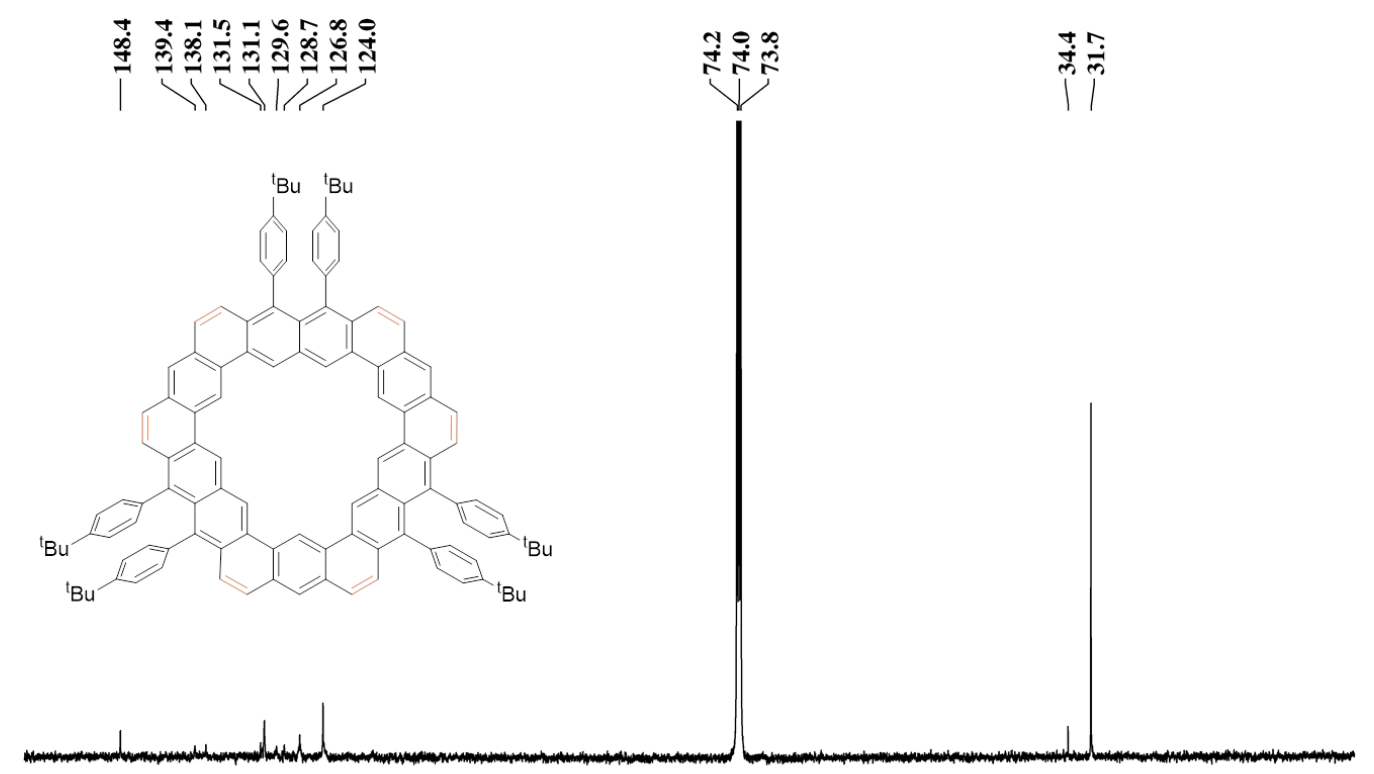

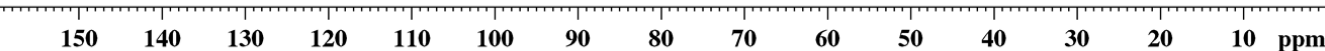

Figure S80. ${ }^{13} \mathrm{C}$ NMR spectrum of [3,4]CA-1 in $\mathrm{CDCl}_{2} \mathrm{CDCl}_{2}(125 \mathrm{MHz}, 298 \mathrm{~K})$

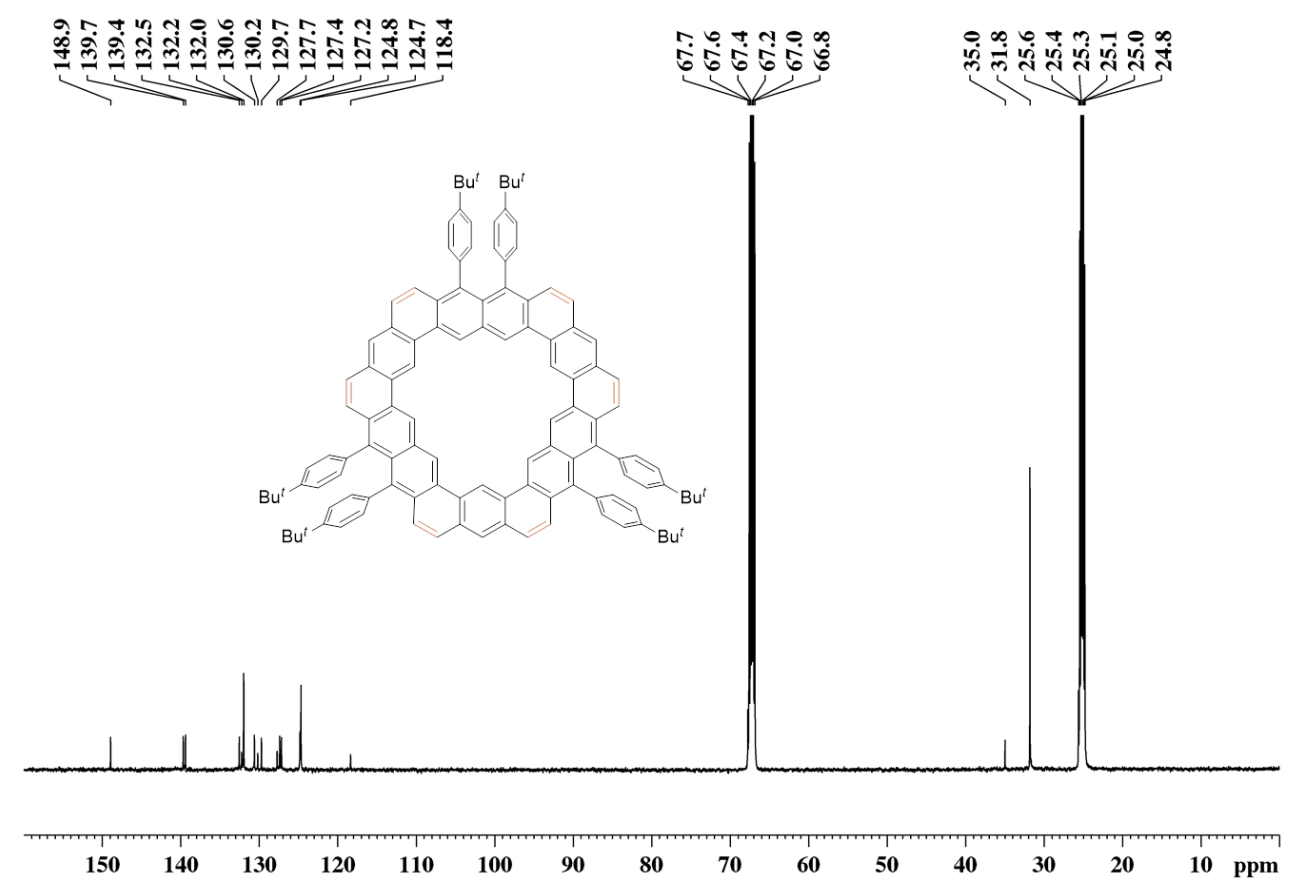

Figure S81. ${ }^{13} \mathrm{C}$ NMR spectrum of [3,4]CA-1 in THF- $d_{8}(125 \mathrm{MHz}, 298 \mathrm{~K})$ 


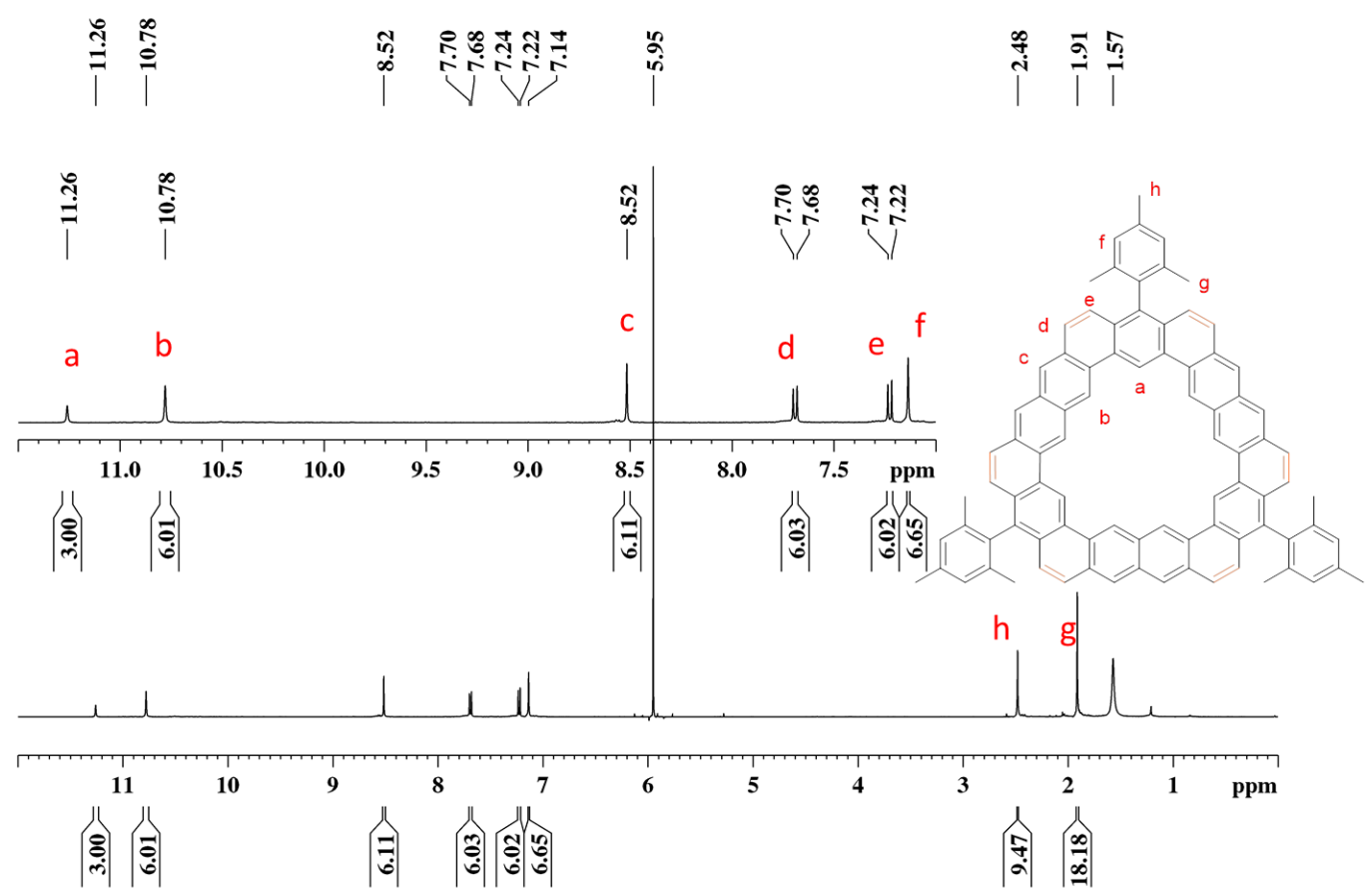

Figure S82. ${ }^{1} \mathrm{H}$ NMR spectrum of $[\mathbf{3 , 4}] \mathbf{C A}-2$ in $\mathrm{CDCl}_{2} \mathrm{CDCl}_{2}(500 \mathrm{MHz}, 298 \mathrm{~K})$

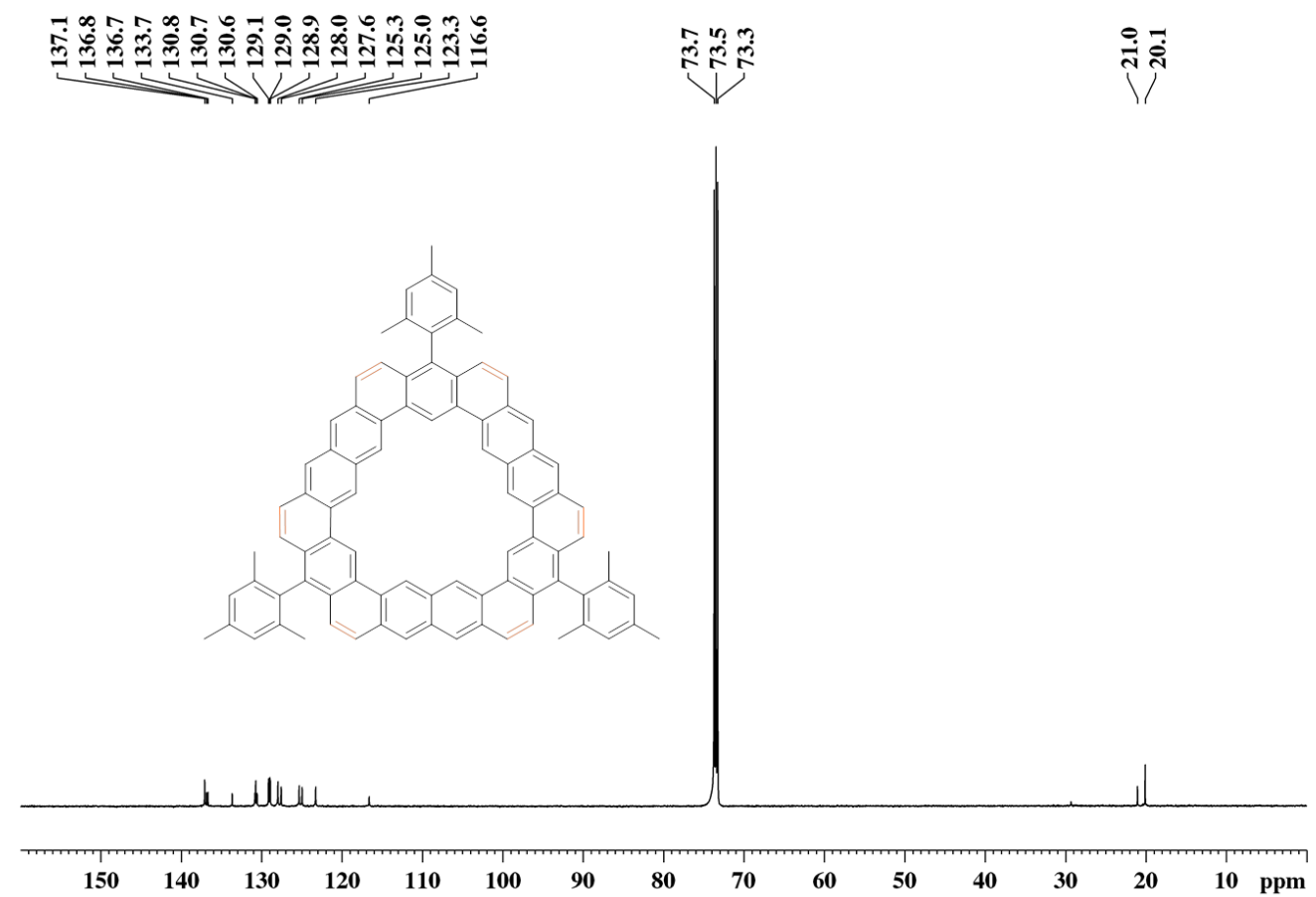

Figure S83. ${ }^{13} \mathrm{C}$ NMR spectrum of $[\mathbf{3 , 4}] \mathbf{C A}-2$ in $\mathrm{CDCl}_{2} \mathrm{CDCl}_{2}(125 \mathrm{MHz}, 298 \mathrm{~K})$ 


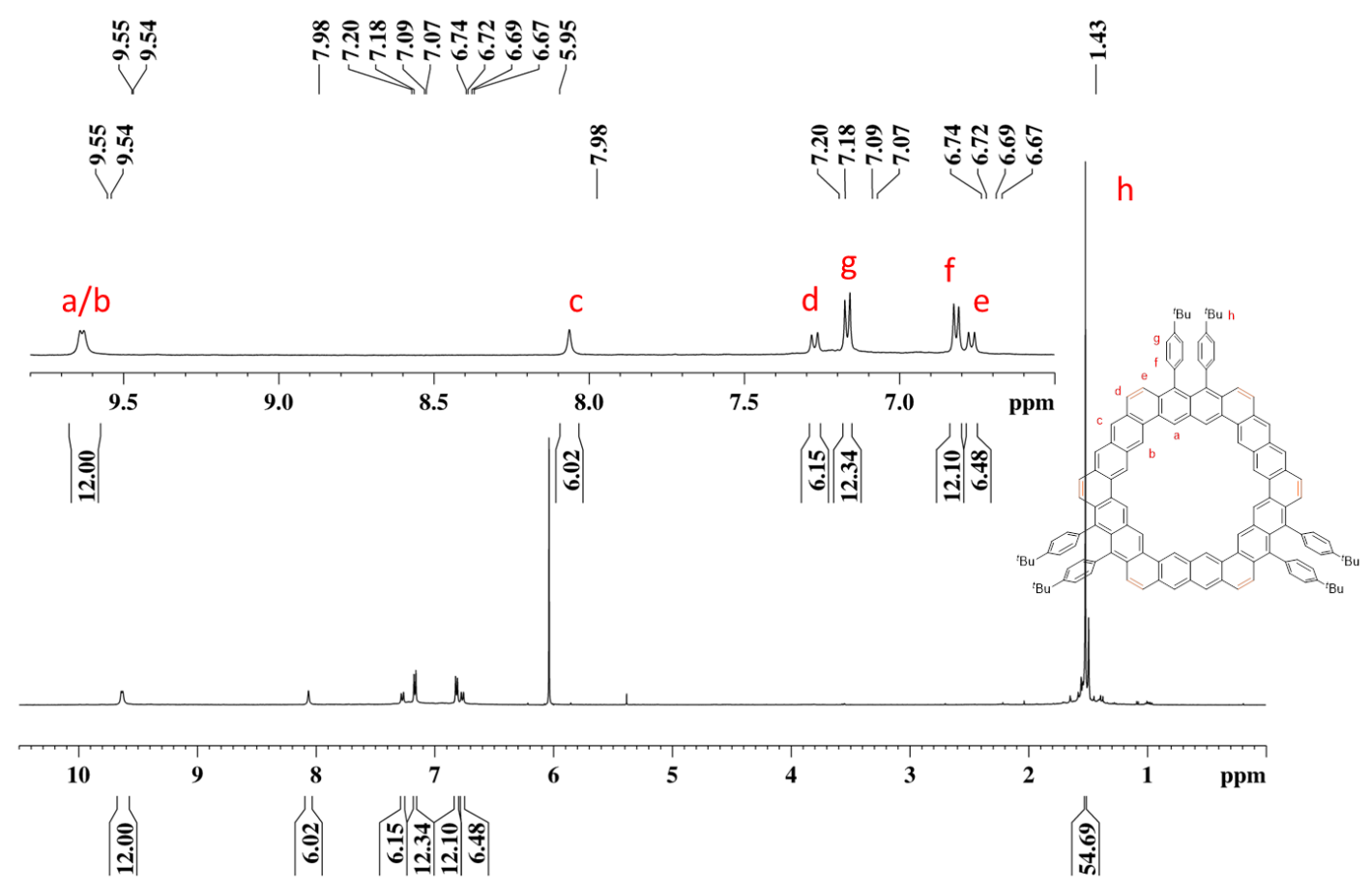

Figure S84. ${ }^{1} \mathrm{H}$ NMR spectrum of $\left[\mathbf{4 , 4 ] C A}\right.$ in $\mathrm{CDCl}_{2} \mathrm{CDCl}_{2}(125 \mathrm{MHz}, 373 \mathrm{~K})$

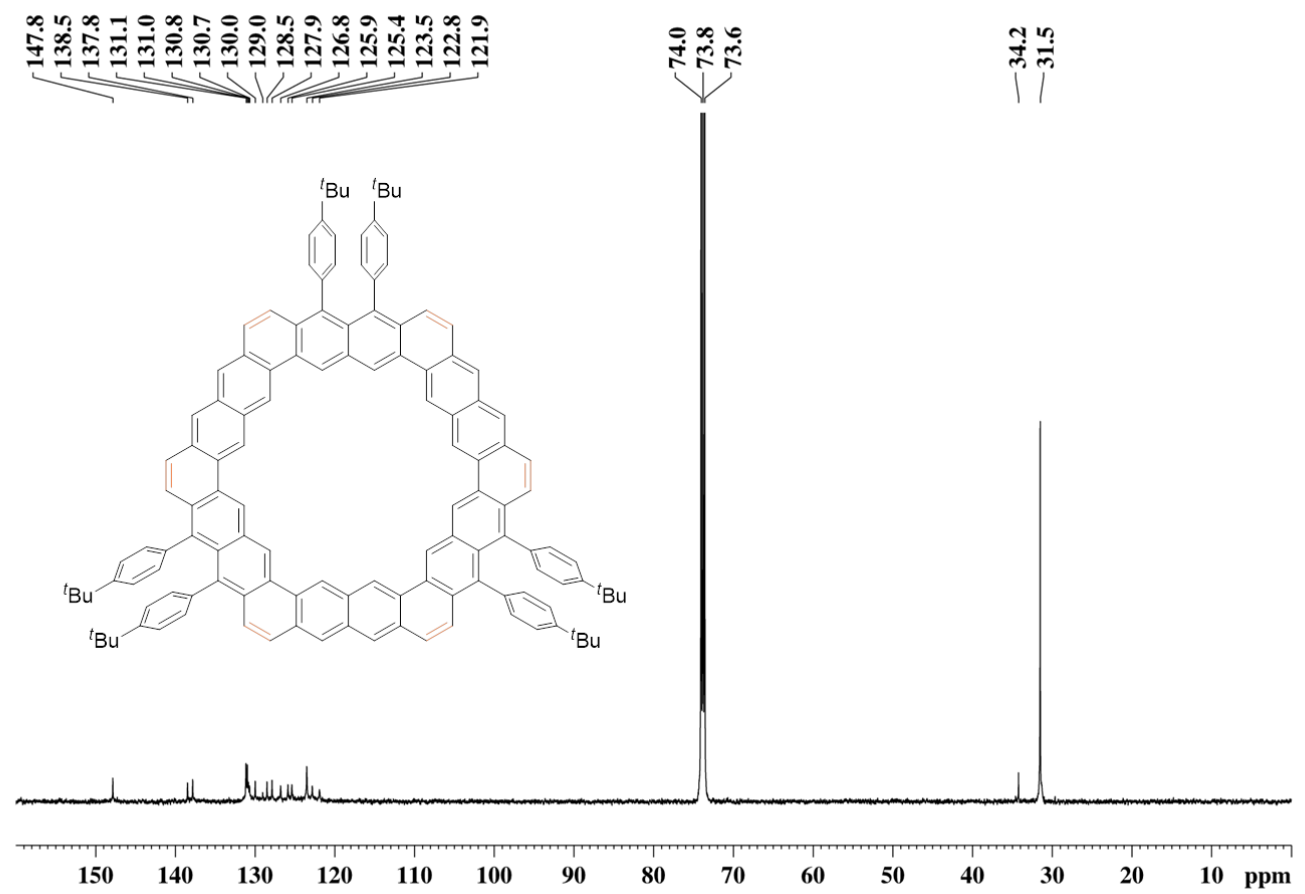

Figure S85. ${ }^{13} \mathrm{C}$ NMR spectrum of $[4,4] \mathbf{C A}$ in $\mathrm{CDCl}_{2} \mathrm{CDCl}_{2}(125 \mathrm{MHz}, 298 \mathrm{~K})$ 


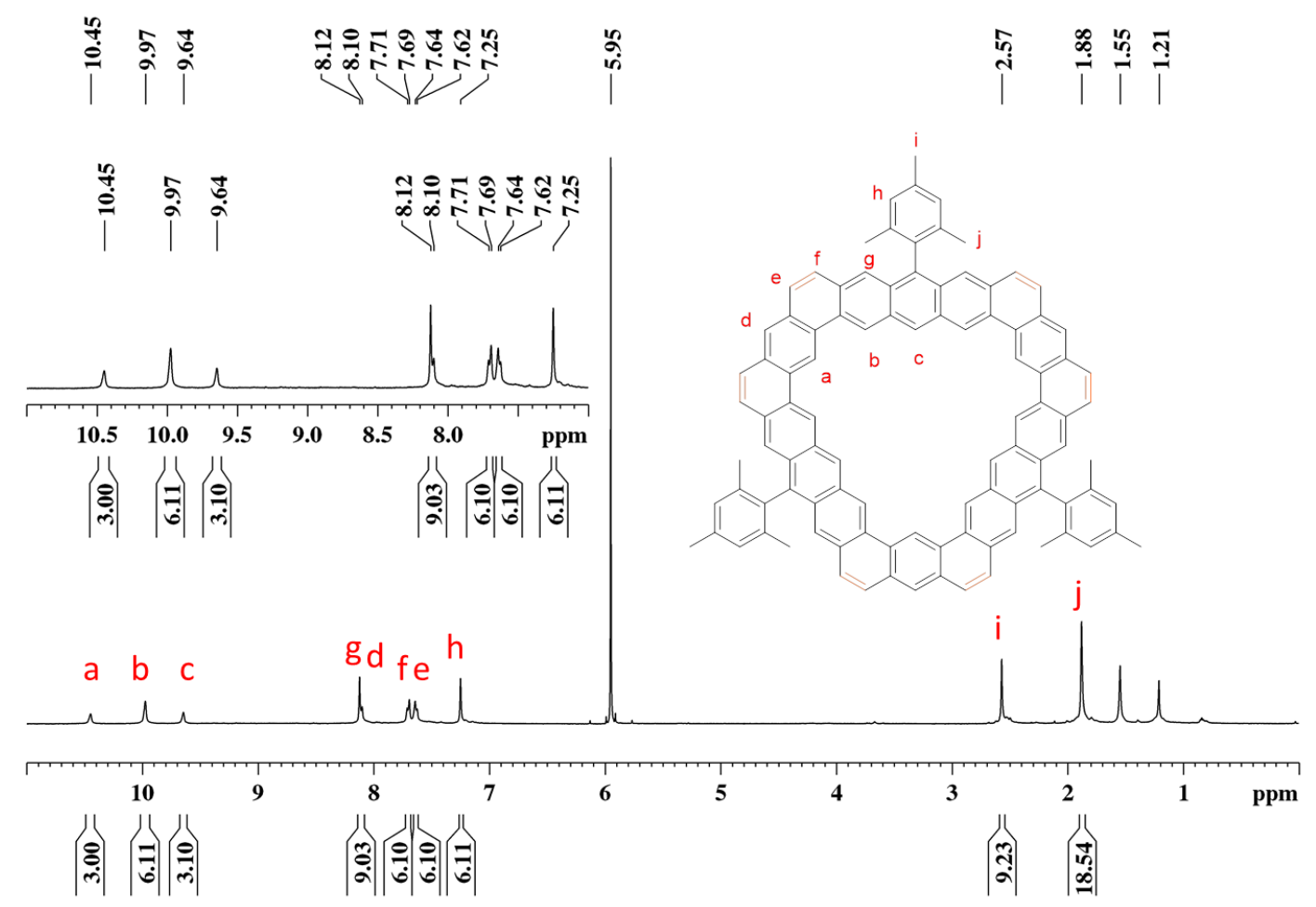

Figure S86. ${ }^{1} \mathrm{H}$ NMR spectrum of $[\mathbf{3 , 5}] \mathbf{C A}$ in $\mathrm{CDCl}_{2} \mathrm{CDCl}_{2}(500 \mathrm{MHz}, 298 \mathrm{~K})$

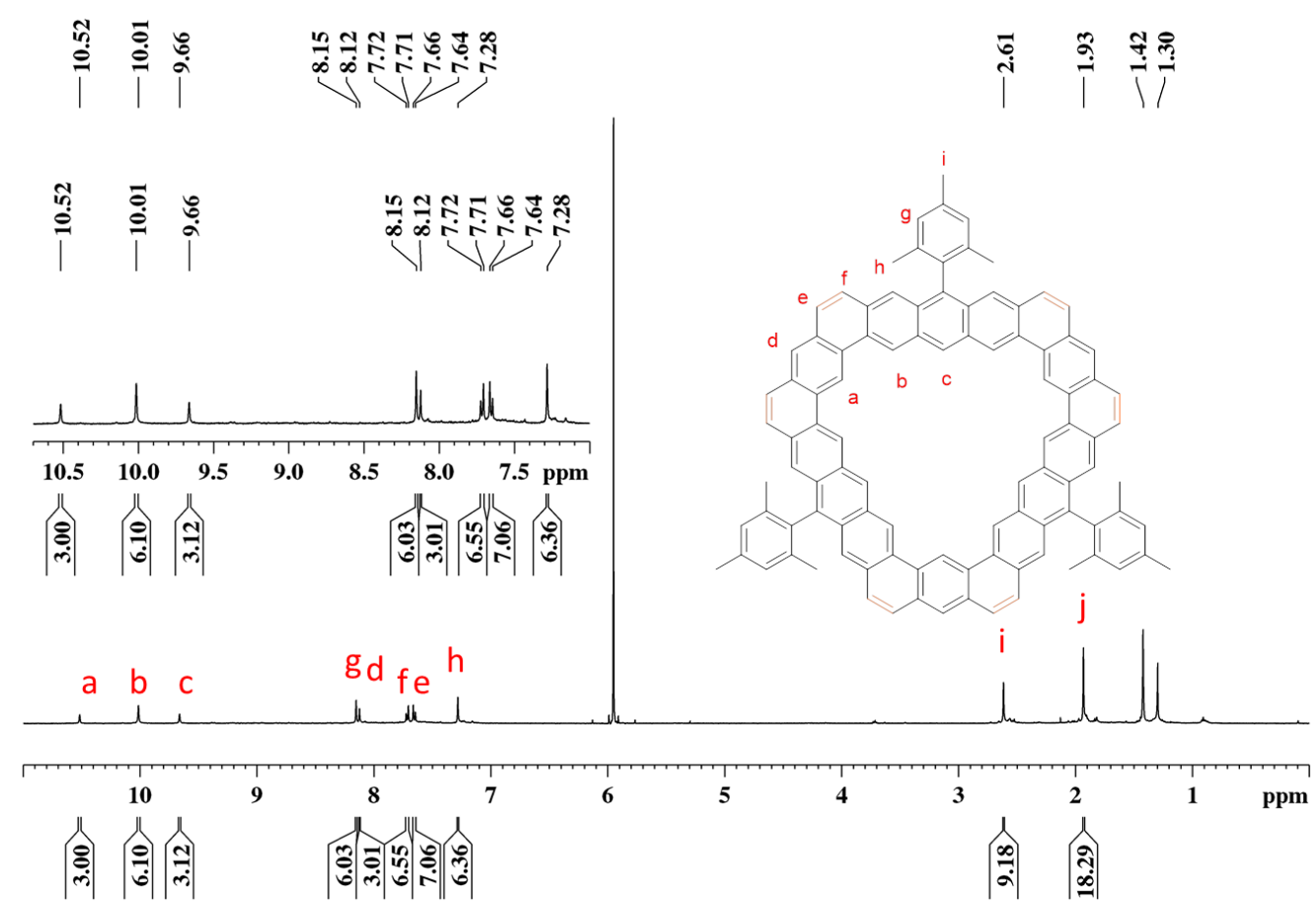

Figure S87. ${ }^{1} \mathrm{H}$ NMR spectrum of $[\mathbf{3 , 5}] \mathbf{C A}$ in $\mathrm{CDCl}_{2} \mathrm{CDCl}_{2}(500 \mathrm{MHz}, 373 \mathrm{~K})$ 


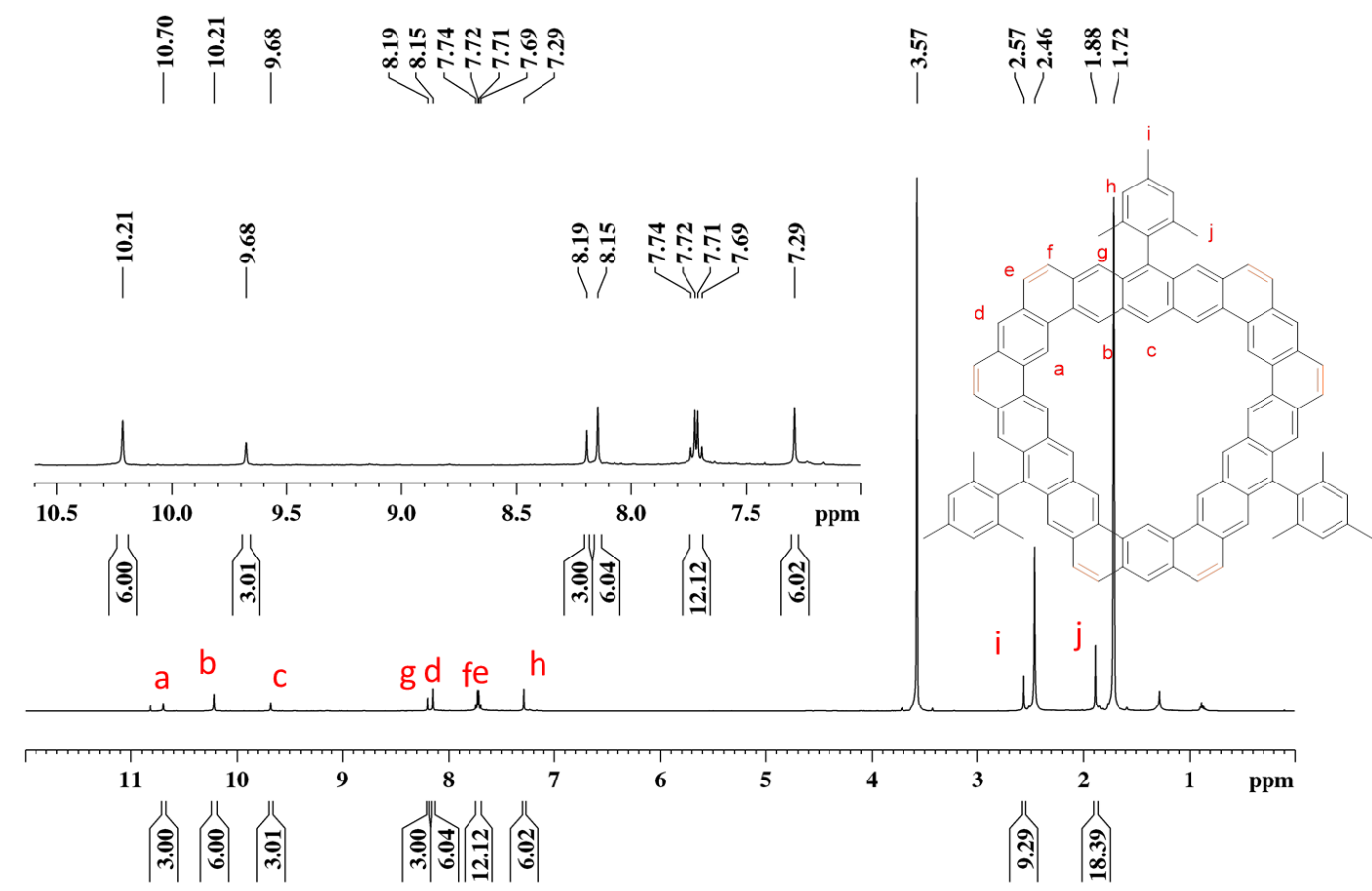

Figure S88. ${ }^{1} \mathrm{H}$ NMR spectrum of $[\mathbf{3 , 5}] \mathbf{C A}$ in THF- $d_{8}(500 \mathrm{MHz}, 298 \mathrm{~K})$

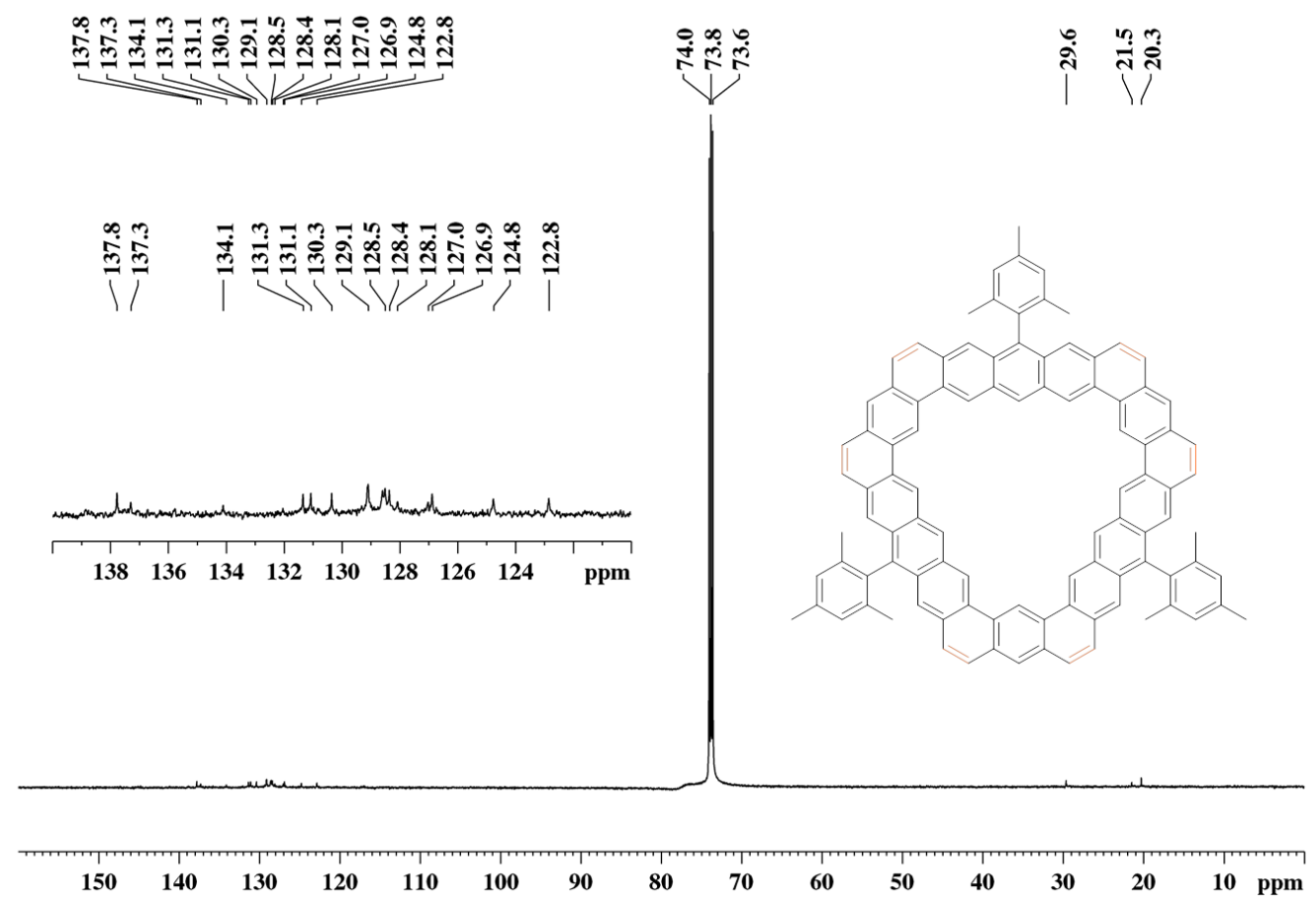

Figure S89. ${ }^{13} \mathrm{C}$ NMR spectrum of [3,5]CA in $\mathrm{CDCl}_{2} \mathrm{CDCl}_{2}(125 \mathrm{MHz}, 298 \mathrm{~K})$ 


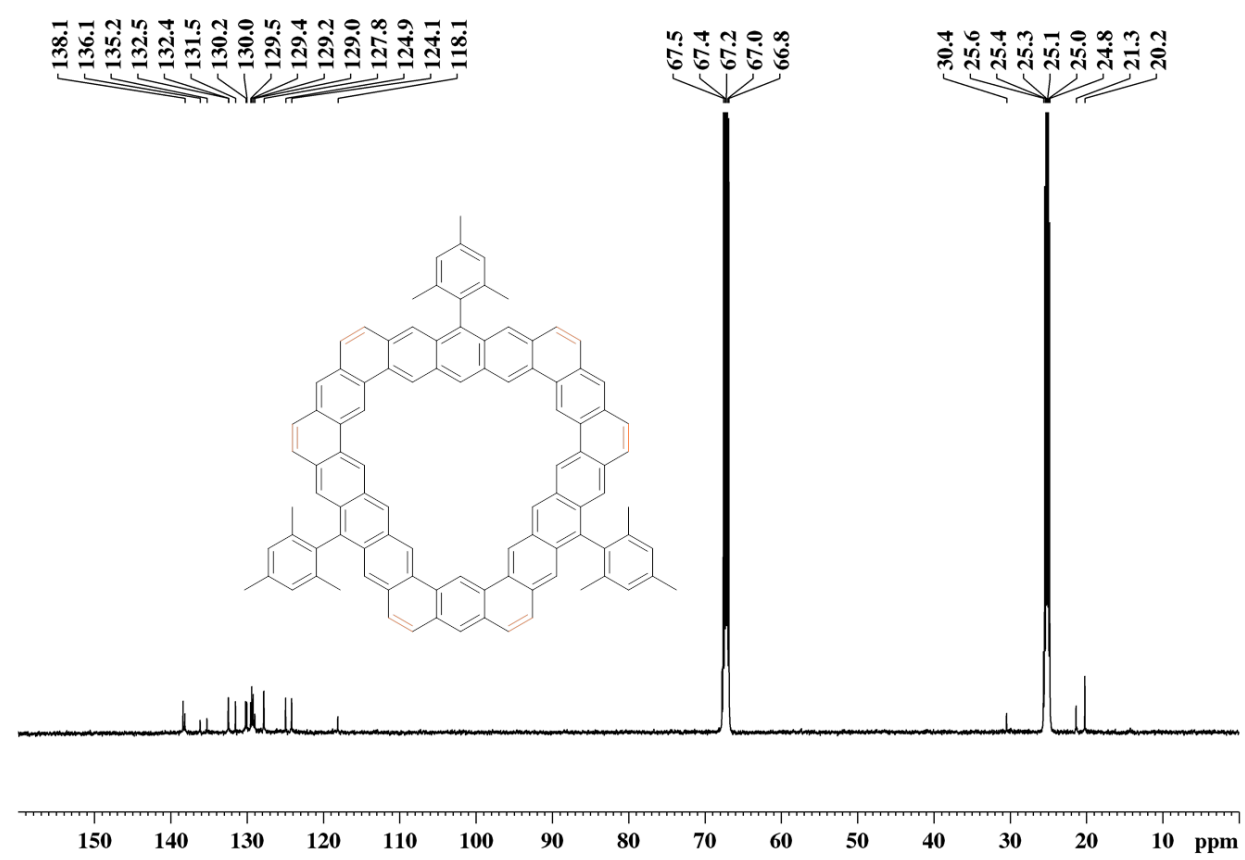

Figure S90. ${ }^{13} \mathrm{C}$ NMR spectrum of [3,5]CA in THF- $d_{8}(125 \mathrm{MHz}, 298 \mathrm{~K})$

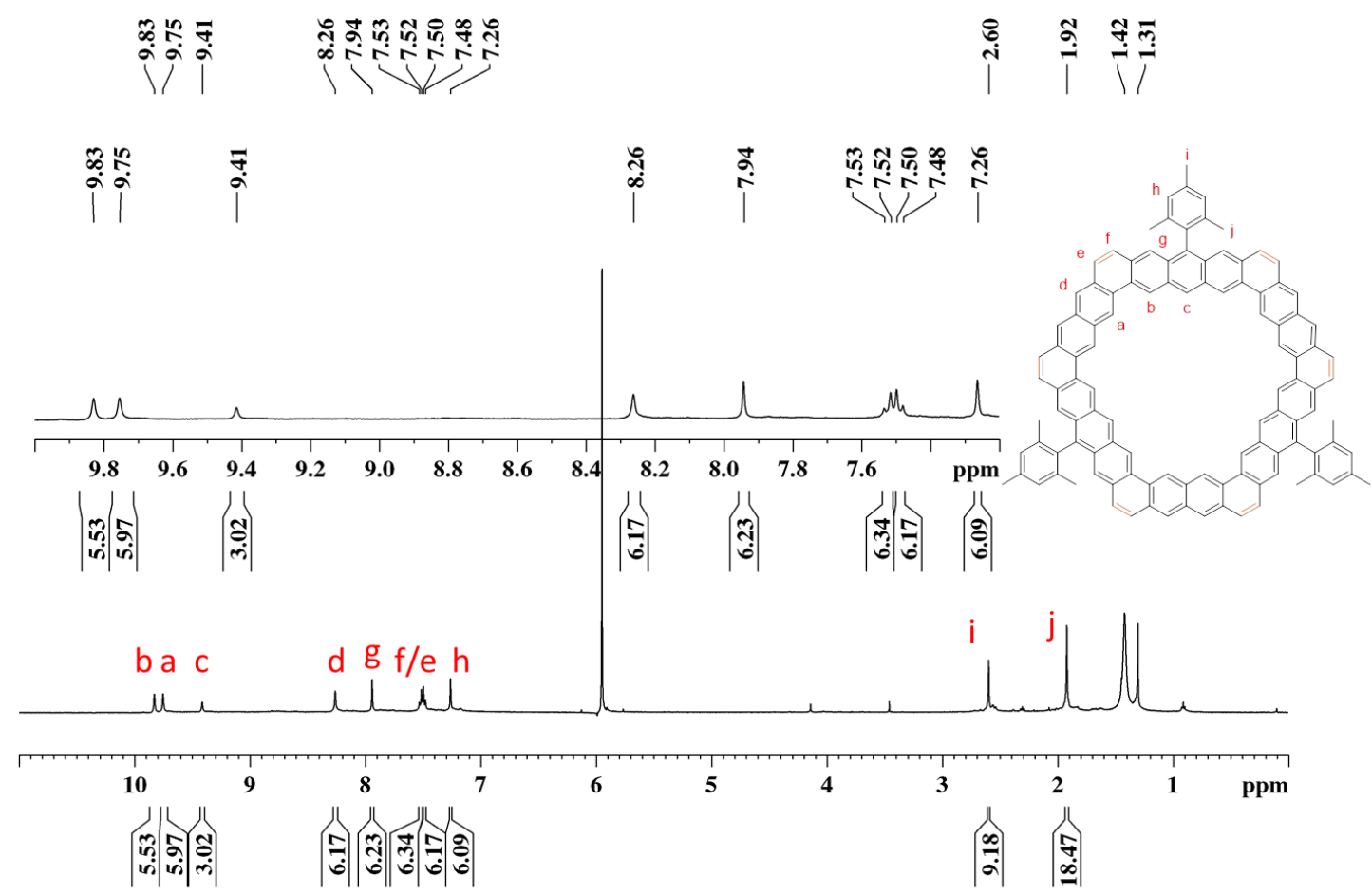

Figure S91. ${ }^{1} \mathrm{H}$ NMR spectrum of [4,5]CA in $\mathrm{CDCl}_{2} \mathrm{CDCl}_{2}(500 \mathrm{MHz}, 373 \mathrm{~K})$ 
Mass Spectrum SmartFormula Report

\begin{tabular}{|c|c|c|c|c|}
\hline Sample Name & $\mathrm{FW}-1$ & & Data File & D:|Chem|2021|202105|20210512\FW-1.D \\
\hline Instrument Name & Agilent $7200 \mathrm{GC}$-QTOF & & $\begin{array}{l}\text { IRM Calibration } \\
\text { Status }\end{array}$ & Success \\
\hline Acq Method & EIHR_CalValve.ei_Wu Jishan_FW.M & & Acquired Time & 12/5/2021 2:53:10 PM (UTC+08:00) \\
\hline Comment & Prof Wu Jishan & & Operator & WLK \\
\hline Meas. $\mathrm{m} / \mathrm{z}$ & Formula & Calc. Mass & Err [ppm] & \\
\hline 392.2501 & $\mathrm{C} 30 \mathrm{H} 32$ & 392.2499 & 0.51 & \\
\hline
\end{tabular}

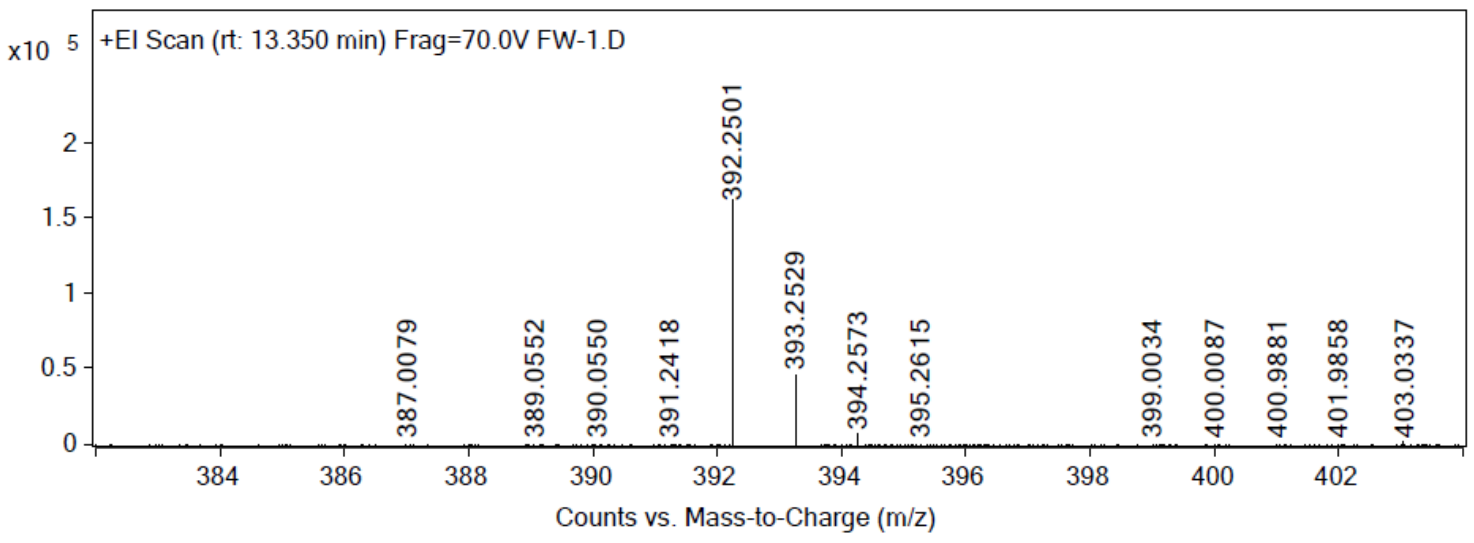

Figure S92. HR mass spectrum (EI) of 5

\section{Mass Spectrum SmartFormula Report}

\begin{tabular}{|c|c|c|c|c|}
\hline Sample Name & FW2 & & Data File & $\begin{array}{l}\text { D:|MassHunter|Data|Chemistry|2021|202105|2021052 } \\
\text { 5\FW2.d }\end{array}$ \\
\hline Instrument Name & Agilent 6546 LC-QTOF & & $\begin{array}{l}\text { IRM Calibration } \\
\text { Status }\end{array}$ & Some Ions Missed \\
\hline Acq Method & MS Scan_union.m & & Acquired Time & 25/5/2021 12:41:41 PM (UTC+08:00) \\
\hline Comment & Dr Koh Ming Joo & & Operator & WLK \\
\hline $\begin{array}{l}\text { Meas. } \mathbf{m} / \mathbf{z} \\
644.4208\end{array}$ & $\begin{array}{ll}\# & \text { Formula } \\
1 & \text { C42 } \mathrm{H} 54[11 \mathrm{~B}] 2 \mathrm{O} 4\end{array}$ & $\begin{array}{l}\text { Calc. Mass } \\
644.4203\end{array}$ & Err $[\mathrm{ppm}]$ & \\
\hline
\end{tabular}

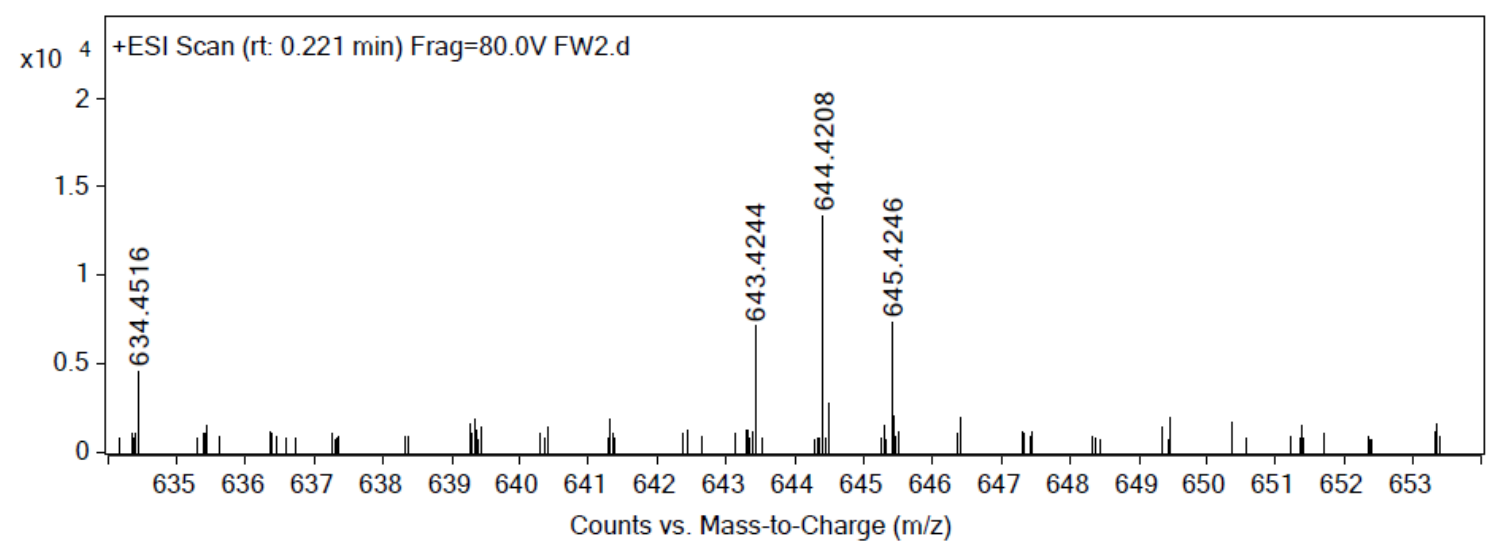

Figure S93. HR mass spectrum (ESI) of D 
Mass Spectrum SmartFormula Report

\begin{tabular}{|c|c|c|c|c|}
\hline Sample Name & $\mathrm{FW}-3$ & & Data File & D:\Chem \2021\202105\20210512\FW-3.D \\
\hline Instrument Name & Agilent $7200 \mathrm{GC}-\mathrm{QTOF}$ & & $\begin{array}{l}\text { IRM Calibration } \\
\text { Status }\end{array}$ & Success \\
\hline Acq Method & EIHR_CalValve.ei_Wu Jishan_FW.M & & Acquired Time & 12/5/2021 4:14:23 PM (UTC+08:00) \\
\hline Comment & Prof Wu Jishan & & Operator & WLK \\
\hline Meas. $\mathrm{m} / \mathrm{z}$ & Formula & Calc. Mass & Err [ppm] & \\
\hline 351.9458 & C15 H14 [79Br]2 & 351.9457 & 0.28 & \\
\hline
\end{tabular}

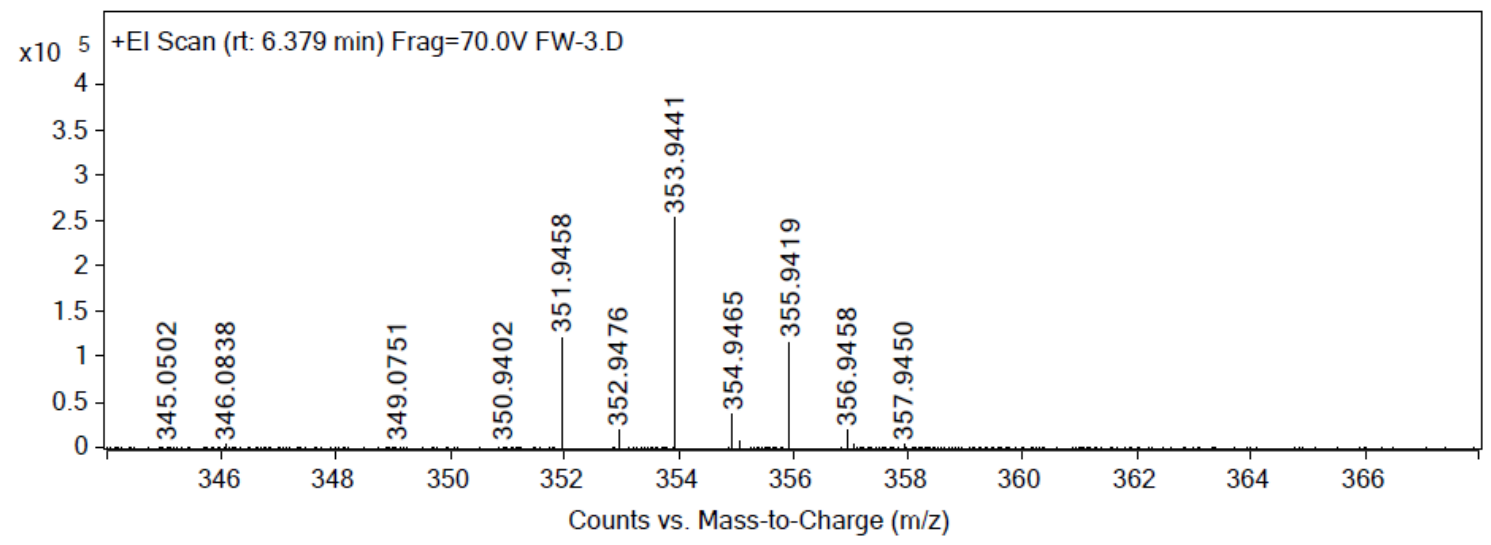

Figure S94. HR mass spectrum (EI) of 9

\section{Mass Spectrum SmartFormula Report}

\begin{tabular}{|c|c|c|c|c|}
\hline Sample Name & FW-4 & & Data File & D:|Chem|2021\202105\20210512\FW-4.D \\
\hline Instrument Name & Agilent $7200 \mathrm{GC}-\mathrm{QTOF}$ & & $\begin{array}{l}\text { IRM Calibration } \\
\text { Status }\end{array}$ & Success \\
\hline Acq Method & EIHR_CalValve.ei_Wu Jishan_FW.M & & Acquired Time & 12/5/2021 4:26:44 PM (UTC+08:00) \\
\hline Comment & Prof Wu Jishan & & Operator & WLK \\
\hline Meas. m/z & Formula & Calc. Mass & Err $[\mathrm{ppm}]$ & \\
\hline 448.2963 & $\mathrm{C} 27 \mathrm{H} 38$ [11B]2 O4 & 448.2951 & 2.68 & \\
\hline
\end{tabular}

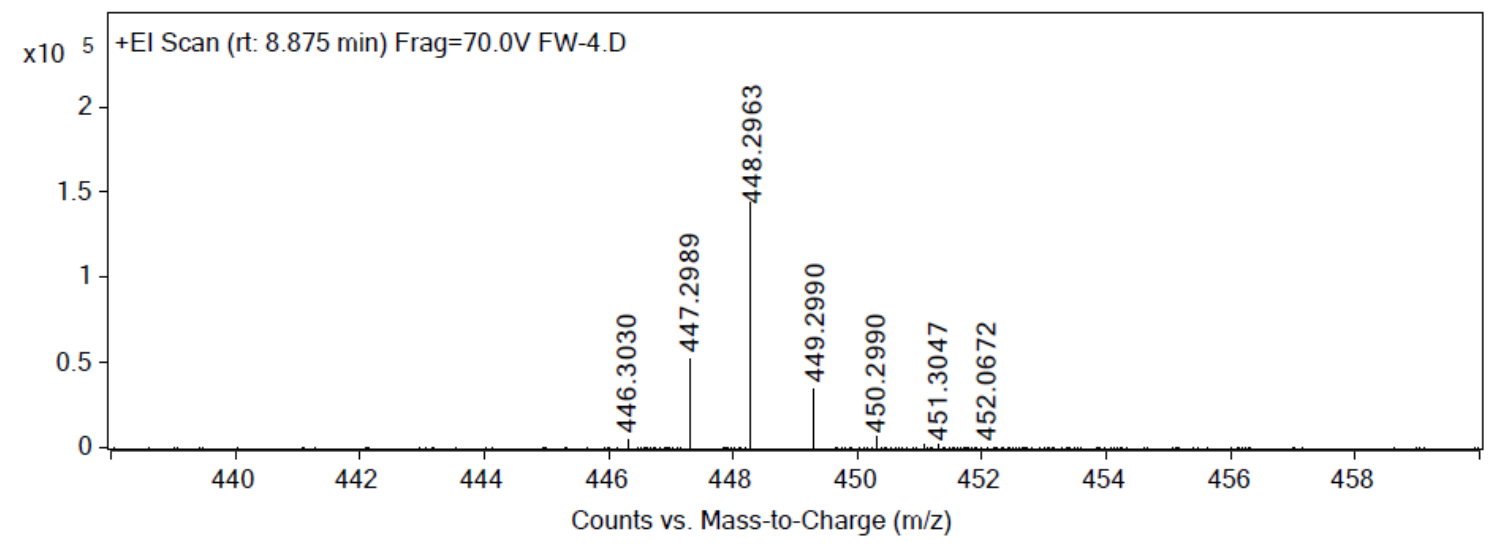

Figure S95. HR mass spectrum (EI) of $\mathbf{C}$ 
Mass Spectrum SmartFormula Report

\begin{tabular}{|c|c|c|c|c|}
\hline Sample Name & $\mathrm{FW}-6$ & & Data File & D:|Chem|2021|202105|20210512|FW-6.D \\
\hline Instrument Name & Agilent 7200 GC-QTOF & & $\begin{array}{l}\text { IRM Calibration } \\
\text { Status }\end{array}$ & Success \\
\hline Acq Method & EIHR_CalValve.ei_Wu Jishan_FW.M & & Acquired Time & 12/5/2021 5:04:33 PM (UTC+08:00) \\
\hline Comment & Prof Wu Jishan & & Operator & WLK \\
\hline $\begin{array}{l}\text { Meas. m/z } \\
296.1558\end{array}$ & $\begin{array}{ll}\# & \text { Formula } \\
1 & \mathrm{C} 23 \mathrm{H} 20\end{array}$ & $\begin{array}{l}\text { Calc. Mass } \\
296.156\end{array}$ & $\begin{array}{l}\text { Err }[p p m] \\
0.68\end{array}$ & \\
\hline
\end{tabular}

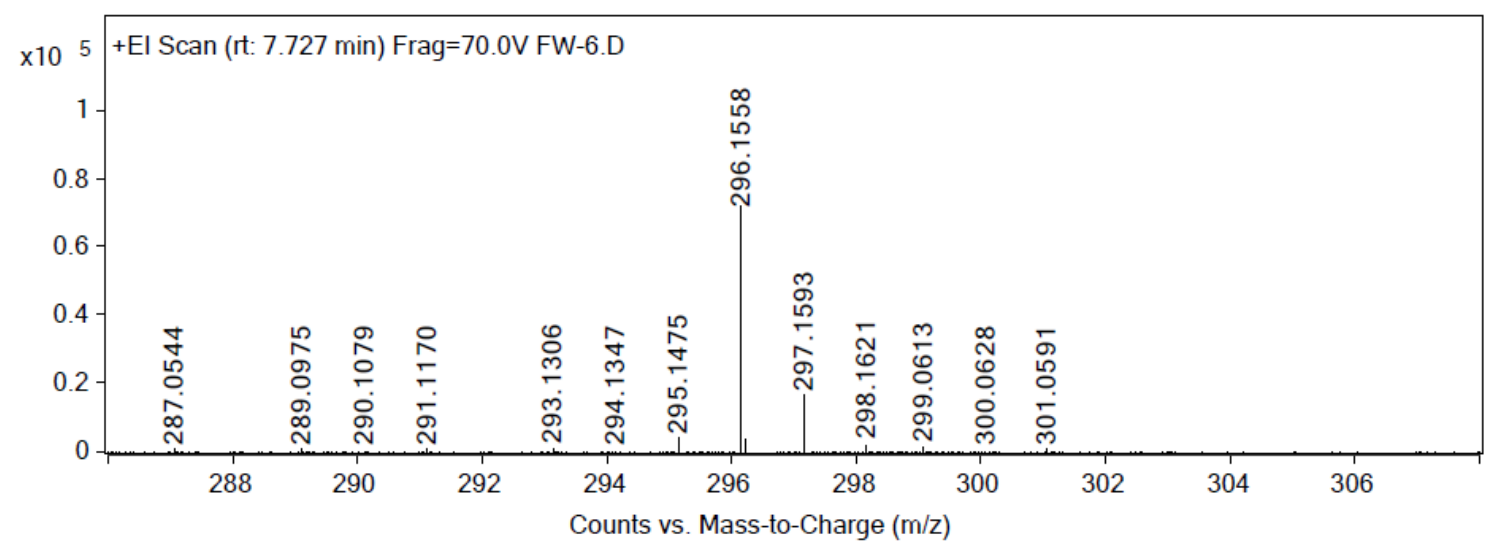

Figure S96. HR mass spectrum (EI) of 8

Mass Spectrum SmartFormula Report

\begin{tabular}{|c|c|c|c|c|}
\hline Sample Name & FW-7 & & Data File & $\begin{array}{l}\text { D:|MassHunter|Data|Chemistry|2021|202105|2021052 } \\
\text { 8\FW-7.d }\end{array}$ \\
\hline Instrument Name & Agilent 6546 LC-QTOF & & $\begin{array}{l}\text { IRM Calibration } \\
\text { Status }\end{array}$ & Some Ions Missed \\
\hline Acq Method & MS Scan_union.m & & Acquired Time & 28/5/2021 5:35:53 PM (UTC+08:00) \\
\hline Comment & Prof Wu Jishan & & Operator & WLK \\
\hline Meas. $\mathbf{m} /$ & Formula & Calc. Mass & Err [ppm] & \\
\hline 549.3352 & $\mathrm{C} 35 \mathrm{H} 43$ [11B]2 04 & 549.3342 & 1.82 & \\
\hline
\end{tabular}

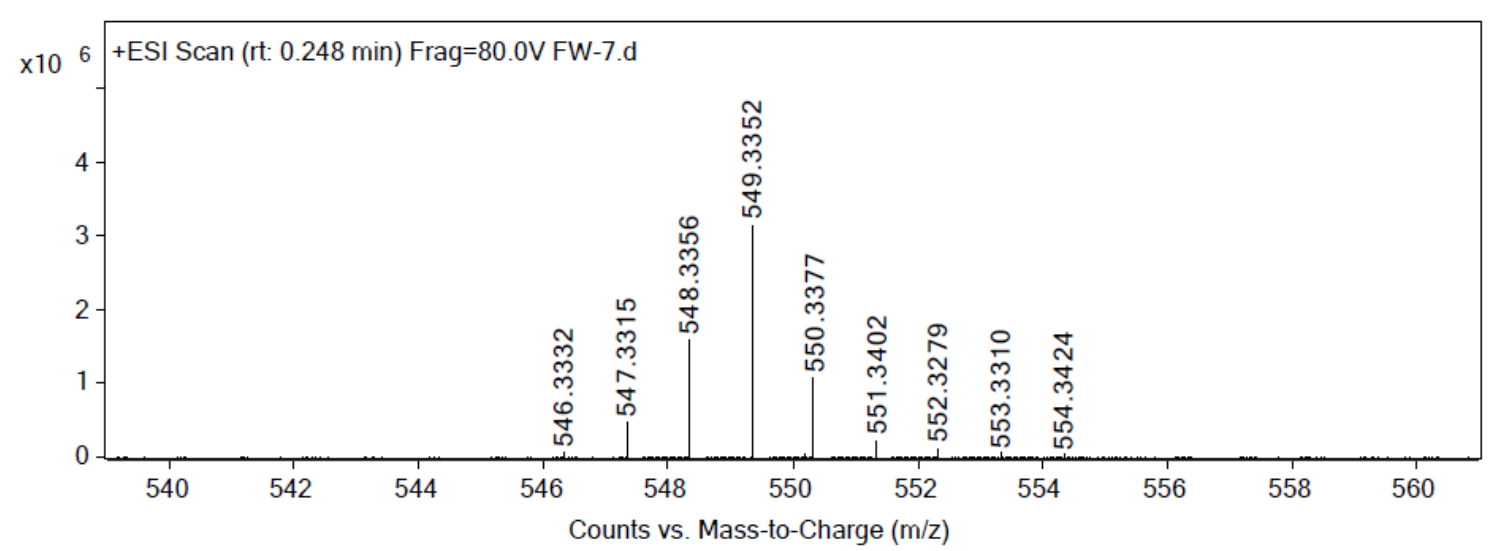

Figure S97. HR mass spectrum (ESI) of $\mathbf{E}$ 


\section{MALDI,2,20210607}

\section{Analysis Info}

Analysis Name

Method

Sample Name

Comment
Acquisition Date 6/7/2021 5:03:54 PM

Operator

Instrument solariX

\begin{tabular}{llllll}
\hline \multicolumn{2}{l}{ Acquisition Parameter } & & & & \\
Acquisition Mode & Single MS & Acquired Scans & 9 & Calibration Date & Tue Jun 104:57:02 2021 \\
Polarity & Positive & No. of Cell Fills & 1 & Data Acquisition Size & 2097152 \\
Broadband Low Mass & $202.1 \mathrm{~m} / \mathbf{z}$ & No. of Laser Shots & 10 & Data Processing Size & 4194304 \\
Broadband High Mass & $3500.0 \mathrm{~m} / \mathbf{z}$ & Laser Power & $50.4 \mathrm{lp}$ & Apodization & Sine-Bell Multiplication \\
Source Accumulation & $0.001 \mathrm{sec}$ & Laser Shot Frequency & $0.020 \mathrm{sec}$ & & \\
lon Accumulation Time & $0.100 \mathrm{sec}$ & & & & \\
\hline
\end{tabular}

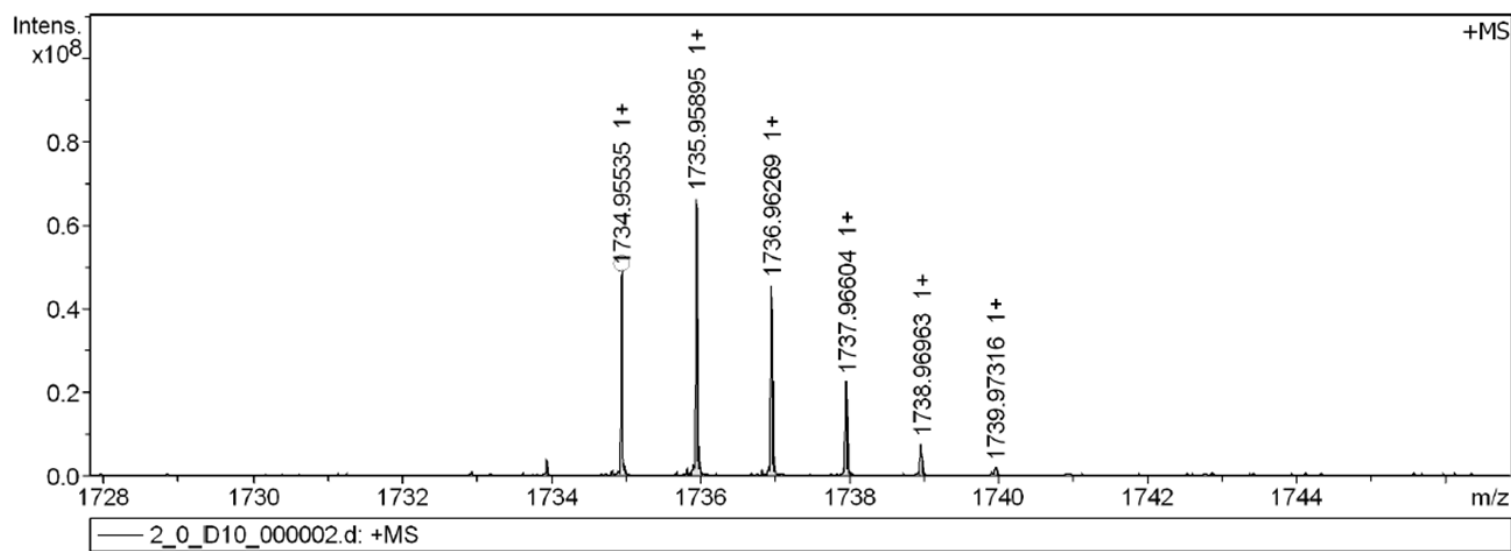

Meas. $\mathrm{m} / \mathrm{z}$ \# Ion Formula Score $\mathrm{m} / \mathrm{z}$ err [ppm] Mean err [ppm] mSigma rdb $\mathrm{e}^{-}$Conf $\mathrm{N}-\mathrm{Rule}$

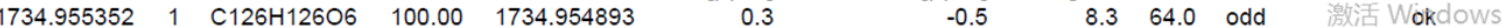

Figure S98. HR mass spectrum (MALDI-TOF) of $\mathbf{1 0}$ 


\section{MALDI,4,20210607}

\section{Analysis Info}

Analysis Name

Method

Sample Name

Comment
Acquisition Date 6/7/2021 5:08:46 PM

Operator

Instrument solariX

\begin{tabular}{|c|c|c|c|c|c|}
\hline \multicolumn{6}{|c|}{ Acquisition Parameter } \\
\hline Acquisition Mode & Single MS & Acquired Scans & 4 & Calibration Date & Tue Jun 1 04:57:02 2021 \\
\hline Polarity & Positive & No. of Cell Fills & 1 & Data Acquisition Size & 2097152 \\
\hline Broadband Low Mass & $202.1 \mathrm{~m} / \mathrm{z}$ & No. of Laser Shots & & Data Processing Size & 4194304 \\
\hline Broadband High Mass & $3800.0 \mathrm{~m} / \mathrm{z}$ & Laser Power & $52.8 \mathrm{Ip}$ & Apodization & Sine-Bell Multiplication \\
\hline Source Accumulation & $0.001 \mathrm{sec}$ & Laser Shot Frequency & $0.020 \mathrm{sec}$ & & \\
\hline Ion Accumulation Time & $0.100 \mathrm{sec}$ & & & & \\
\hline
\end{tabular}

Intens MALDI_P_100-3000

MURU-N-ESI

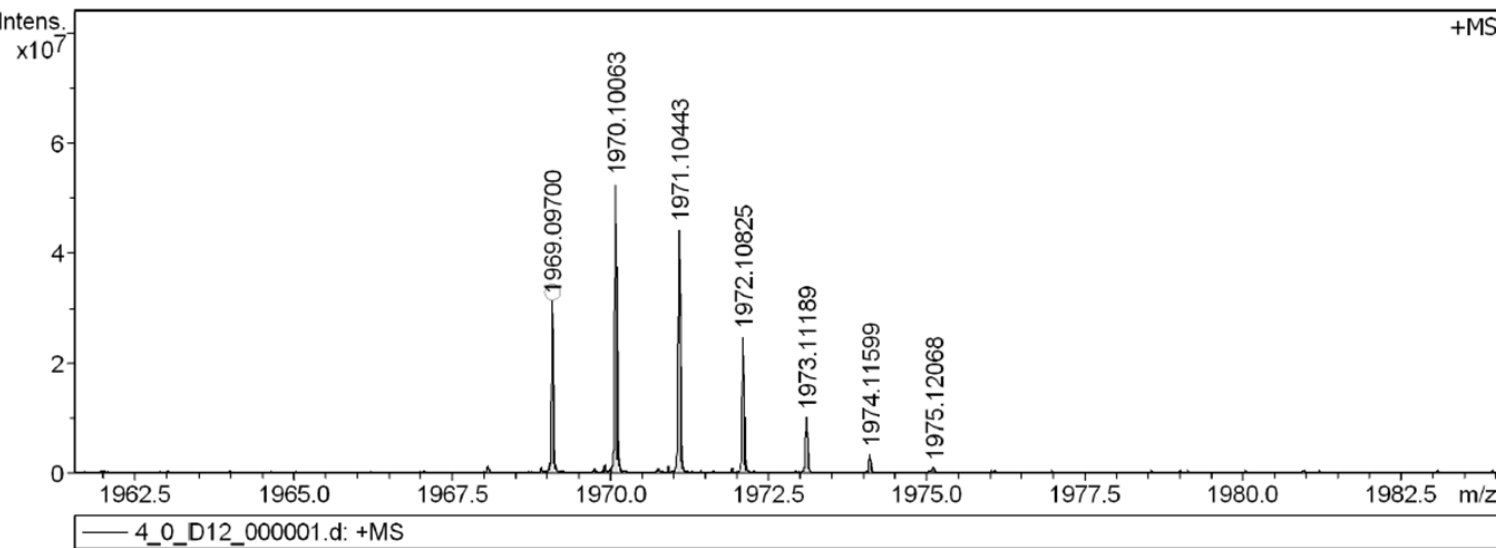

Meas. $\mathrm{m} / \mathrm{z}$ \# Ion Formula Score

$\mathrm{m} / \mathbf{z}$ err [ppm] Mean err [ppm] mSigma rdb e Conf N-Rule 1969.097002

1 C144H14406 $100.00 \quad 1969.095744$

0.6

$-0.9$

$33.7 \quad 73.0$ odd

ok

Figure S100. HR mass spectrum (MALDI-TOF) of 12 


\section{MALDI,5,20210607}

Analysis Info

Analysis Name

Method

Sample Name

Comment
Acquisition Date 6/7/2021 5:10:53 PM

D:IDatalMALDII20211060715_0_D13_000003.d

MALDI_P_100-3000

MURU-N-ESI

Acquisition Parameter Acquisition Mode

Polarity

Broadband Low Mass

Broadband High Mass

Single MS

Positive

$202.1 \mathrm{~m} / \mathrm{z}$

$2800.0 \mathrm{~m} / \mathrm{z}$

$0.001 \mathrm{sec}$

on Accumulation Time

$0.100 \mathrm{sec}$
Operator

Instrument solariX

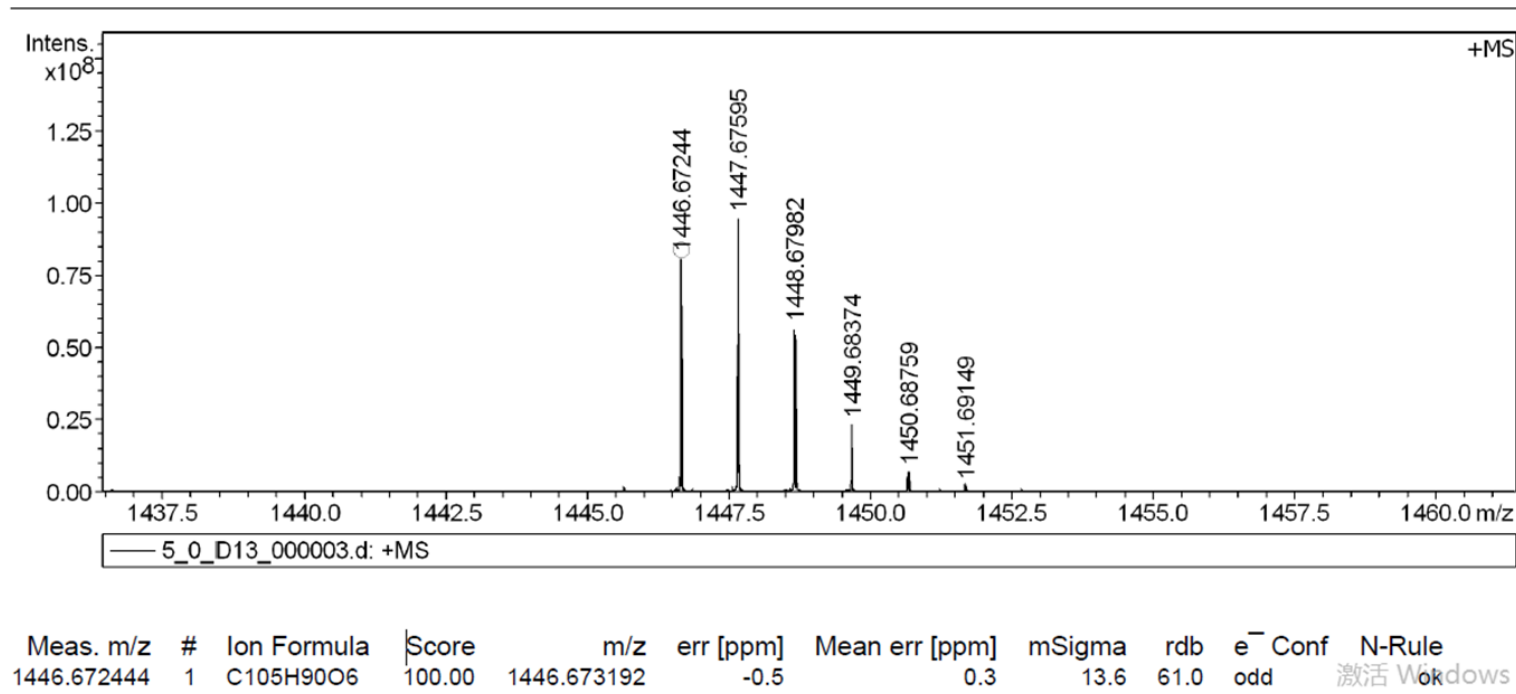

Figure S101. HR mass spectrum (MALDI-TOF) of $\mathbf{1 3}$ 


\section{MALDI,1,20210622}

Analysis Info

Analysis Name

Method

Sample Name

Comment
Acquisition Date 6/24/2021 6:09:32 PM

Operator

Instrument solariX

\section{Acquisition Parameter}

Acquisition Mode Single MS

Polarity

D:IData\MALDI\2021\0624\1_0_C2_000001.d

MALDI_P_100-3000

MURU-N-ES

Single MS Acquired Scans

Positive

Broadband High Mass $3200.0 \mathrm{~m} / \mathrm{z}$

No. of Cell Fills

No. of Laser Shots

8

Laser Power

Calibration Date

Data Acquisition Size

Thu Jun 24 06:06:37

$0.001 \mathrm{sec}$

Laser Shot Frequency

2027152

Ion Accumulation Time $0.100 \mathrm{sec}$

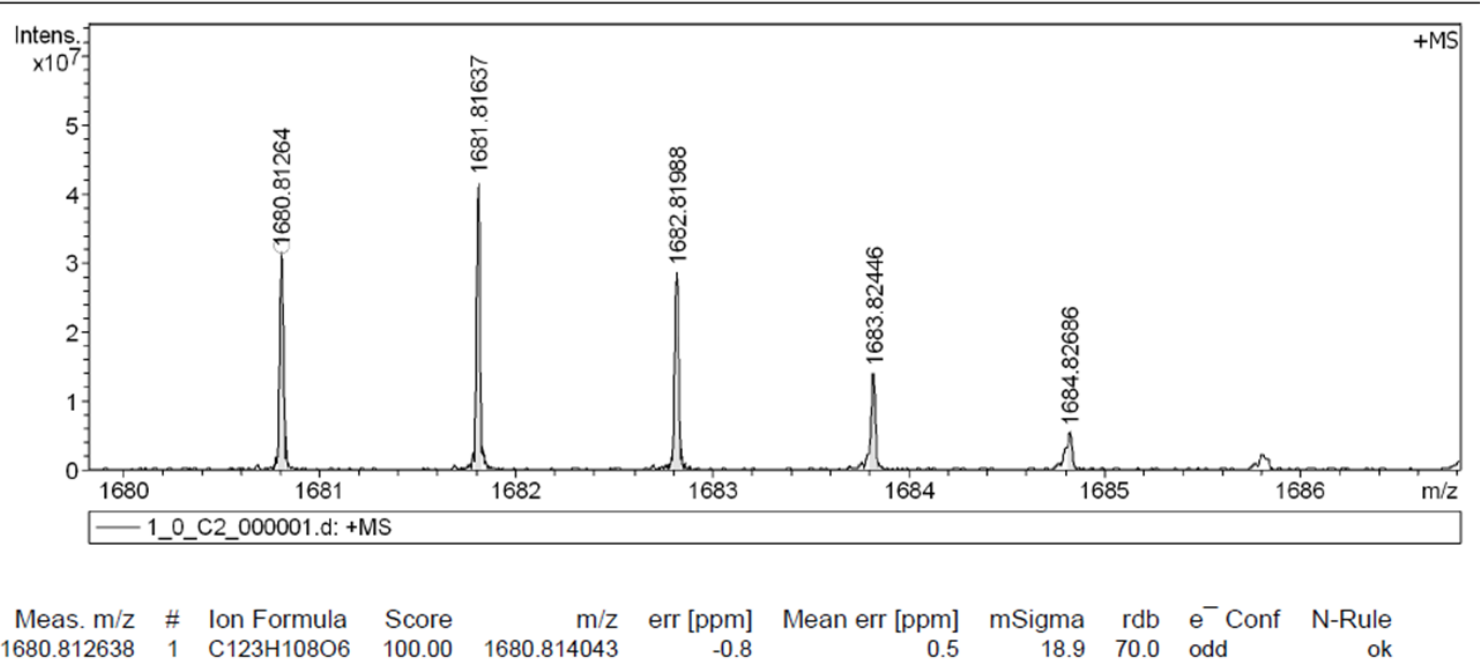

Figure S102. HR mass spectrum (MALDI-TOF) of 14 


\section{MALDI,7,20210607}

Analysis Info

Analysis Name

Method

Sample Name

Comment
Acquisition Date 6/7/2021 5:14:53 PM

Operator

Instrument solariX

\begin{tabular}{llllll}
\hline \multicolumn{2}{l}{ Acquisition Parameter } & & & \\
Acquisition Mode & Single MS & Acquired Scans & 2 & Calibration Date & Tue Jun $104: 57: 02$ 2021 \\
Polarity & Positive & No. of Cell Fills & 1 & Data Acquisition Size & 2097152 \\
Broadband Low Mass & $202.1 \mathrm{~m} / \mathbf{z}$ & No. of Laser Shots & 10 & Data Processing Size & 4194304 \\
Broadband High Mass & $3000.0 \mathrm{~m} / \mathbf{z}$ & Laser Power & $40.0 \mathrm{lp}$ & Apodization & Sine-Bell Multiplication \\
Source Accumulation & $0.001 \mathrm{sec}$ & Laser Shot Frequency & $0.020 \mathrm{sec}$ & & \\
lon Accumulation Time & $0.100 \mathrm{sec}$ & & & &
\end{tabular}

on Accumulation Time $0.100 \mathrm{sec}$

MALDI_P_100-3000

MURU-N-ESI

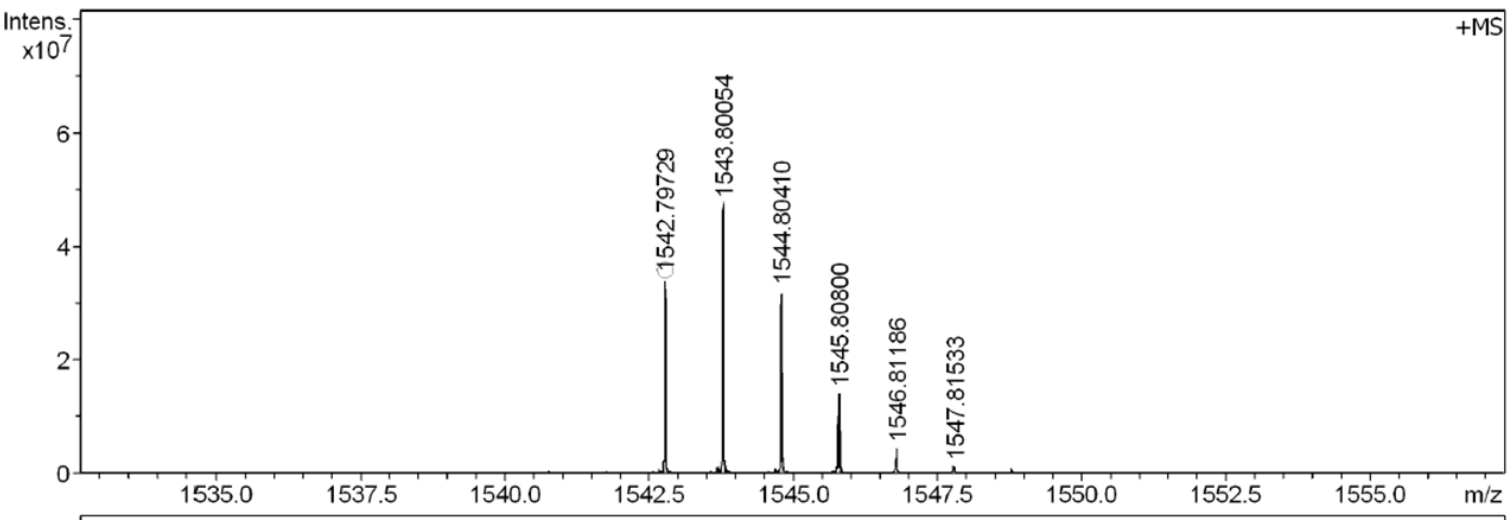

Meas. $\mathrm{m} / \mathrm{z}$ \# Ion Formula Score

$1542.797288 \quad 1 \quad \mathrm{C} 12 \mathrm{OH} 102$

$100.00 \quad 1542.797605$

err [ppm] Mean err [ppm] mSigma $\mathrm{rdb} \mathrm{e}^{-}$Conf N-Rule

Figure S103. HR mass spectrum (MALDI-TOF) of [3,4]CA-1 


\section{MALDI,8,20210607}

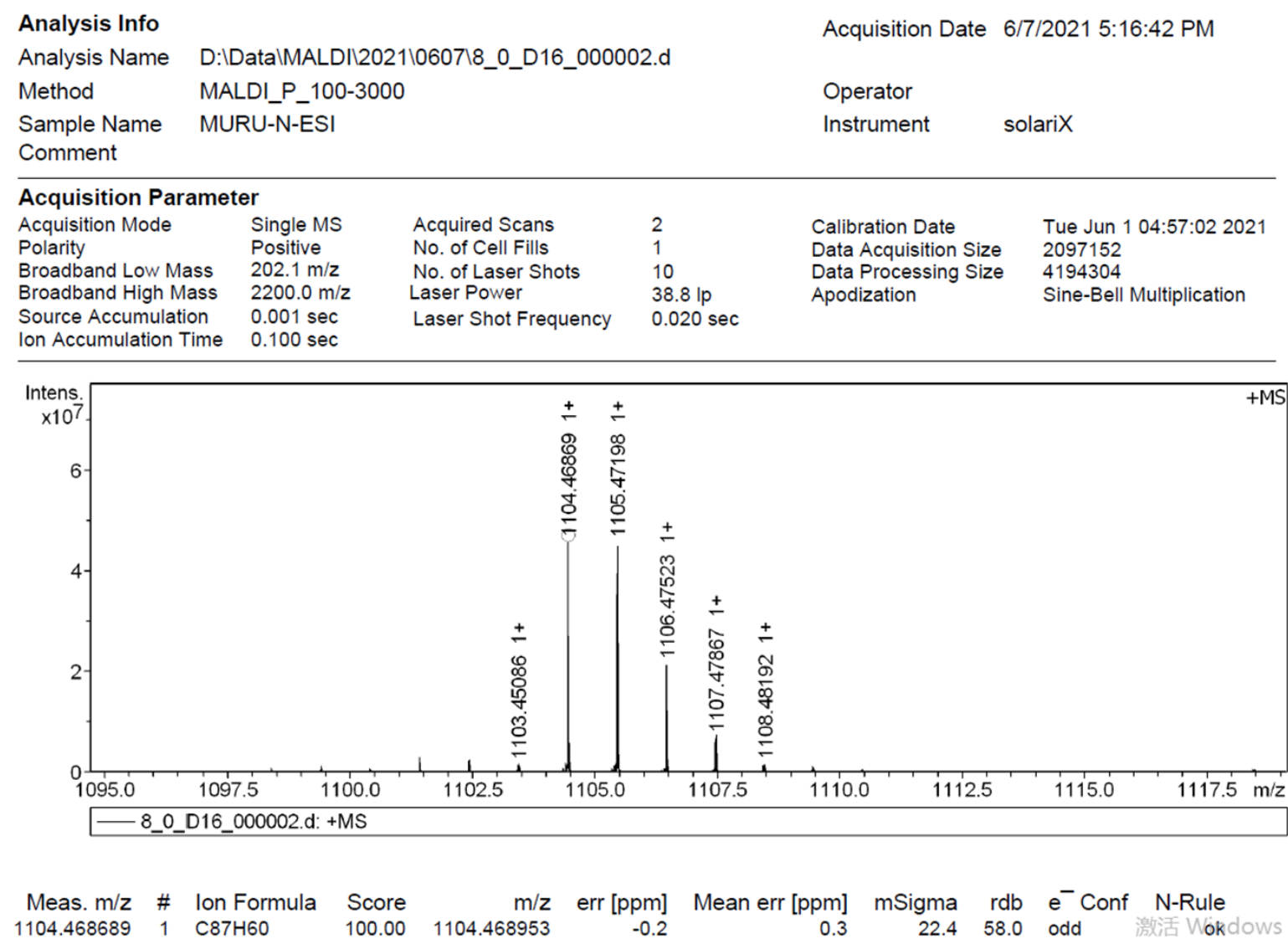

Figure S104. HR mass spectrum (MALDI-TOF) of $[\mathbf{3 , 4}] \mathrm{CA}-2$ 


\section{MALDI,9,20210607}

\section{Analysis Info}

Analysis Name

Method

Sample Name Comment
Acquisition Date 6/7/2021 5:21:45 PM

D:IDatalMALDII20211060719_0_D17_000001.d

MALDI_P_100-3000

MURU-N-ESI

Operator

Instrument solariX

\section{Acquisition Parameter}

Acquisition Mode

Polarity Positive

Broadband Low Mass $202.1 \mathrm{~m} / \mathrm{z}$

Broadband High Mass $3200.0 \mathrm{~m} / \mathrm{z}$

Source Accumulation $\quad 0.001 \mathrm{sec}$

Ion Accumulation Time $0.100 \mathrm{sec}$

\section{Acquired Scans \\ 19}

No. of Cell Fills

No. of Laser Shots

Laser Power

Laser Shot Frequency

10

$38.8 \mathrm{lp}$

$0.020 \mathrm{sec}$

Calibration Date

Data Acquisition Size

Data Processing Size

Apodization

Tue Jun 1 04:57:02 2021 2097152

4194304

Sine-Bell Multiplication

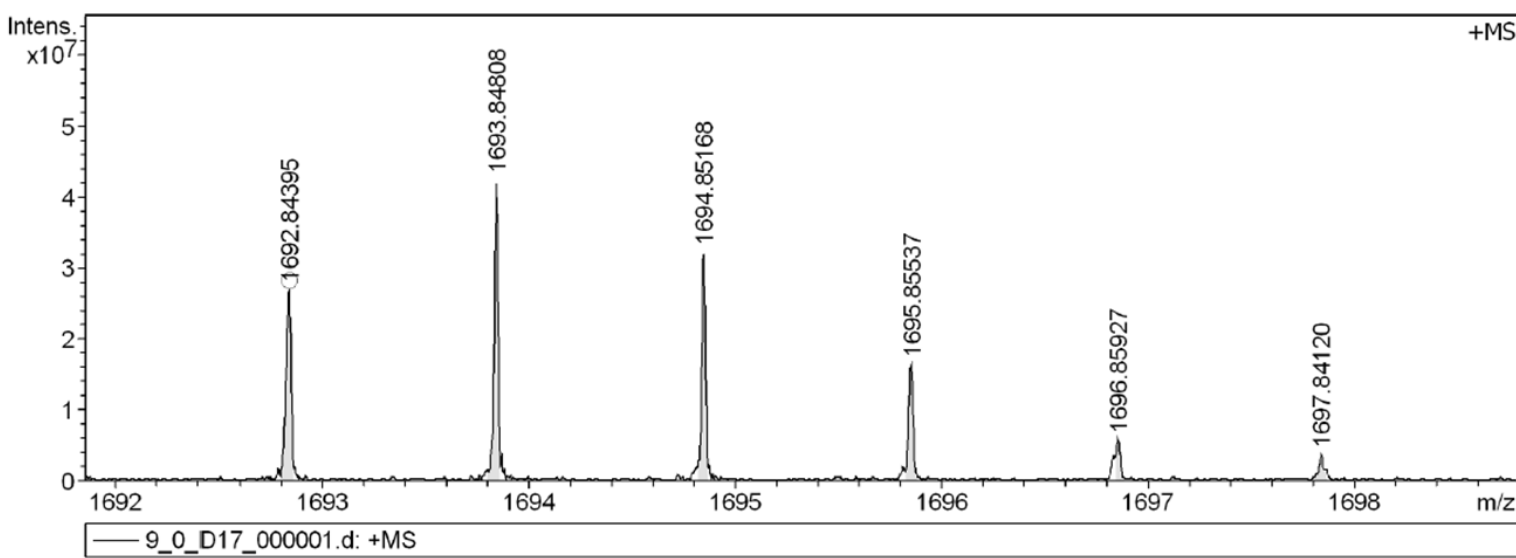

Meas. $\mathrm{m} / \mathrm{z}$ \# Ion Formula Score

$\mathrm{m} / \mathbf{z}$ err $[\mathrm{ppm}]$ Mean err $[\mathrm{ppm}]$ mSigma $\mathrm{rdb} \mathrm{e}^{-}$Conf N-Rule $1692.843952 \quad 1 \quad \mathrm{C} 132 \mathrm{H} 108 \quad 100.00$ $\mathrm{m} / \mathrm{z}$
1692.844555

$-0.4$

$-0.1$

36.279 .0 odd

Figure S105. HR mass spectrum (MALDI-TOF) of $[4,4]$ CA 


\section{MALDI,10,20210607}

Analysis Info

Analysis Name

Method

Sample Name

Comment

Acquisition Parameter

Polarity

Broadband Low Mass

Broadband

Source Accumulation

D:IData|MALDII2021/0607\10_0_D18_000002.d

MALDI_P_100-3000

MURU-N-ESI

Ion Accumulation Time Acquired Scans

No. of Cell Fills

No. of Laser Shots 10

Laser Power $\quad 42.4 \mathrm{lp}$

$202.1 \mathrm{~m} / \mathrm{z}$

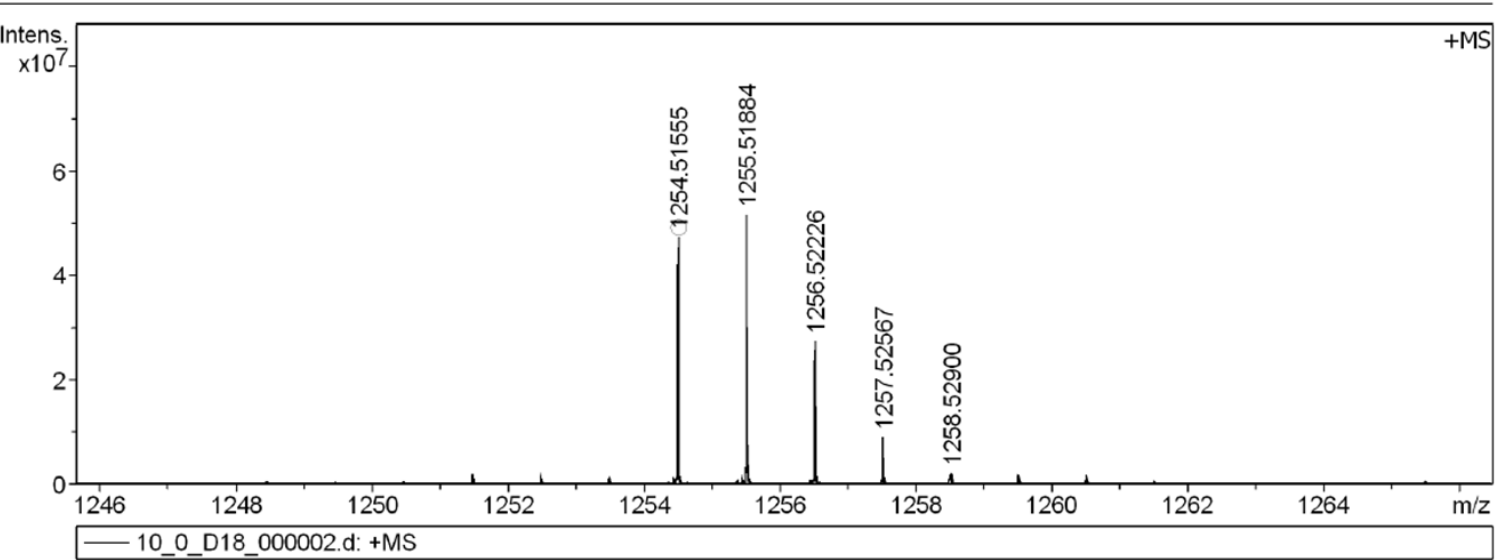

Meas. $\mathrm{m} / \mathrm{z}$ \# Ion Formula Score

Tue Jun 1 04:57:02 2021

Data Acquisition Size

2097152

Data Processing Size

Operator

Instrument

solariX

Apodization

$0.020 \mathrm{sec}$

Sine-Bell Multiplication

$254.5155541 \mathrm{c} 99 \mathrm{H} 66$

$\mathrm{m} / \mathbf{z}$ err [ppm] Mean err [ppm] mSigma $\mathrm{rdb} \mathrm{e}^{-}$Conf N-Rule

1254.515904

0.3

0.3

8.167 .0 odd

ok

Figure S106. HR mass spectrum (MALDI-TOF) of [3,5]CA 


\section{MALDI,11,20210607}

Analysis Info Analysis Name Method

Sample Name Comment
Acquisition Date 6/7/2021 5:25:52 PM

Operator

Instrument solariX

\section{Acquisition Parameter}

Acquisition Mode Single MS

Polarity

Broadband Low Mass

Broadband High Mas

Source Accumulation

Positive

$202.1 \mathrm{~m} / \mathrm{z}$

$2800.0 \mathrm{~m} / \mathrm{z}$

$0.001 \mathrm{sec}$

$0.100 \mathrm{sec}$
Acquired Scans $\quad 15$

No. of Cell Fills

No. of Laser Shots

Laser Power

1

10

Laser Shot Frequency

Calibration Date

Data Acquisition Size

Tue Jun 1 04:57:02 2021

2097152

Apodization

$0.020 \mathrm{sec}$

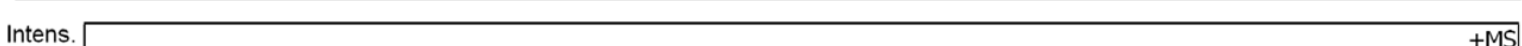

$x 107$

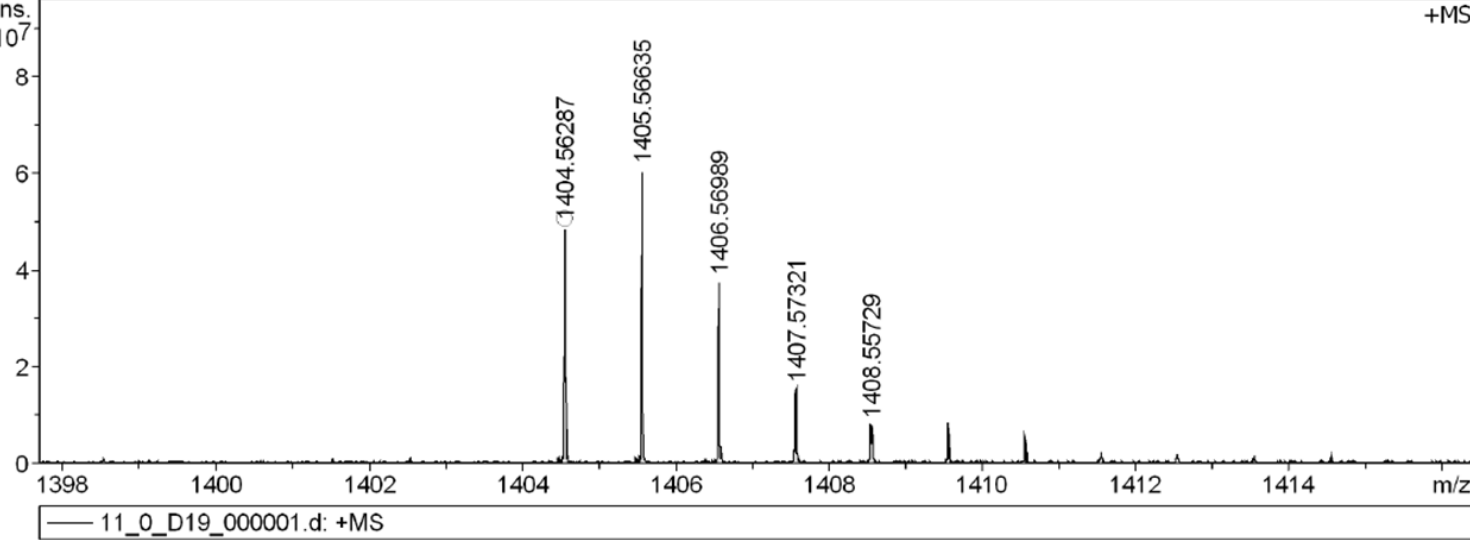

Meas. $\mathrm{m} / \mathrm{z}$ \# Ion Formula Score $1404.562867 \quad 1 \quad \mathrm{C} 111 \mathrm{H} 72$

$\mathrm{m} / \mathbf{z}$ err [ppm

Mean err $[p p$

$\begin{array}{rrlr}\text { mSigma } & \text { rdb } & e^{-} \text {Conf } & N-R u l e \\ 14.9 & 76.0 & \text { odd } & \text { ok }\end{array}$

Figure S107. HR mass spectrum (MALDI-TOF) of [4,5]CA 


\section{References}

(1) Hinderberg, P.; Busch, M.; Paul, A.; Bernhardt, M.; Gemessy, P.; Rominger, F.; Romero-Nieto, C. Diphosphahexaarenes as Highly Fluorescent and Stable Materials. Angew.Chem. Int. Ed. 2018, 57, 15157.

(2) Gaussian 09; Revision A.2; Frisch, M. J.; Trucks, G. W.; Schlegel, H. B.; Scuseria, G. E.; Robb, M. A.; Cheeseman, J. R.; Scalmani, G.; Barone, V.; Mennucci, B.; Petersson, G. A.; Nakatsuji, H.; Caricato, M.; Li, X.; Hratchian, H. P.; Izmaylov, A. F.; Bloino, J.; Zheng, G.; Sonnenberg, J. L.; Hada, M.; Ehara, M.; Toyota, K.; Fukuda, R.; Hasegawa, J.; Ishida, M.; Nakajima, T.; Honda, Y.; Kitao, O.; Nakai, H.; Vreven, T.; Montgomery, J., J. A.; Peralta, J. E.; Ogliaro, F.; Bearpark, M.; Heyd, J. J.; Brothers, E.; Kudin, K. N.; Staroverov, V. N.; Kobayashi, R.; Normand, J.; Raghavachari, K.; Rendell, A.; Burant, J. C.; Iyengar, S. S.; Tomasi, J.; Cossi, M.; Rega, N.; Millam, N. J.; Klene, M.; Knox, J. E.; Cross, J. B.; Bakken, V.; Adamo, C.; Jaramillo, J.; Gomperts, R.; Stratmann, R. E.; Yazyev, O.; Austin, A. J.; Cammi, R.; Pomelli, C.; Ochterski, J. W.; Martin, R. L.; Morokuma, K.; Zakrzewski, V. G.; Voth, G. A.; Salvador, P.; Dannenberg, J. J.; Dapprich, S.; Daniels, A. D.; Farkas, Ö.; Foresman, J. B.; Ortiz, J. V.; Cioslowski, J.; Fox, D. J.; Gaussian, Inc., Wallingford CT, 2009.

(3) (a) Becke, A. D. Density-functional thermochemistry. III. The role of exact exchange. $J$. Chem. Phys. 1993, 98, 5648. (b) Lee, C.; Yang, W.; Parr, R. G. Development of the Colle-Salvetti correlation-energy formula into a functional of the electron density. Phys. Rev. B: Condens. Matter 1988, 37, 785. (c) Yanai, T.; Tew, D.; Handy, N. A new hybrid exchange-correlation functional using the Coulomb-attenuating method (CAM-B3LYP). Chem. Phys. Lett. 2004, 393, 51. (d). Ditchfield, R; Hehre, W. J.; Pople, J. A. SelfConsistent Molecular-Orbital Methods. IX. An Extended Gaussian-Type Basis for Molecular-Orbital Studies of Organic Molecules. J. Chem. Phys. 1971, 54, 724. (e) Hehre, W. J.; Ditchfield, R.; Pople, J. A. Self-Consistent Molecular Orbital Methods. XII. Further Extensions of Gaussian-Type Basis Sets for Use in Molecular Orbital Studies of Organic Molecules. J. Chem. Phys. 1972, 56, 2257. (f) Hariharan, P. C.; Pople J. A. The influence of polarization functions on molecular orbital hydrogenation energies. Theor. Chim. Acta 1973, 28, 213.

(4) Schleyer, P. v. R.; Maerker, C.; Dransfeld, A.; Jiao, H. J.; Hommes, N. J. R. V. Nucleus-Independent Chemical Shifts: A Simple and Efficient Aromaticity Probe. J. Am. Chem. Soc. 1996, 118, 6317.

(5) Geuenich, D.; Hess, K.; Kohler, F.; Herges, R. Anisotropy of the Induced Current Density (ACID), a General Method To Quantify and Visualize Electronic Delocalization. Chem. Rev. 2005, 105, 3758.

(6) Lu, T.; Chen, F. Multiwfn: A multifunctional wavefunction analyser. J. Comput. Chem. 2012, 33, 580 .

(7) Humphrey, W.; Dalke, A.; Schulten, K. VMD: Visual molecular dynamics. J. Mol. Graph. 1996, 14, 33.

(8) SADABS. Ver. 2014/5. Krause, L., Herbs-Irmer, R., Sheldrick, G. M. Stalke, D. (2015). J. 
Appl. Crystallogr. 48.

(9) SHELXT-Integrated space-group and crystal-structure determination Sheldrick, G. M. Acta Crystallogr., Sect. A 2015, A71, 3.

(10) SHELXTL G. M. Sheldrick, Ver. 2014/7. Acta Crystallographica. Sect C Structural Chemistry 71, 3.

(11)Farrugia, L. J. WinGX. J. Appl. Cryst. 1999, 32, 837. 